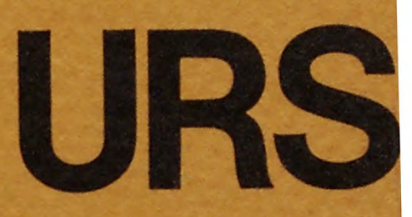

\title{
SEISMIC DAMAGE ASSESSMENT FOR HIGH-RISE BUILDINGS
}

ANNUAL TECHNICAL REPORT

sponsored by the U.S. Geological Survey

Contract No. 14-08-0001-16814

prepared by

URS/John A. Blume \& Associates, Engineers 130 Jessie Street (at New Montgomery)

San Francisco, California 94105 


\title{
SEISMIC DAMAGE ASSESSMENT FOR HIGH-RISE BUILDINGS
}

\author{
ANNUAL TECHNICAL REPORT
}

\section{URS}

Sponsored by the

U.S. Geological Survey

Contract No. 14-08-0001-16814

Contractor:

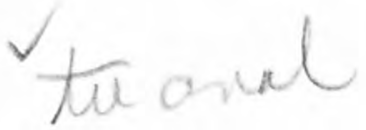

URS/John A. Blume \& Associates, Engineers

130 Jessie Street (at New Montgomery)

San Francisco, California 94105

Principal Investigator:

Government Technical Officer:

Effective Date of Contract:

Contract Expiration Date:

Amount of Contract:
Roger E. Scholl

Gordon W. Greene

March 9, 1978

May 8,1980

$\$ 248,475$ 
ACKNOWLEDGMENTS $\ldots \ldots \ldots \ldots \ldots \ldots \ldots \ldots \ldots \ldots \ldots \ldots \ldots \ldots \ldots \ldots \ldots$

EXECUTIVE SUMMARY $\ldots \ldots \ldots \ldots \ldots \ldots \ldots \ldots \ldots \ldots \ldots \ldots \ldots \ldots \ldots \ldots \ldots \ldots$

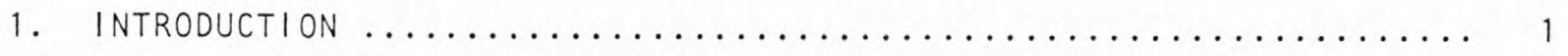

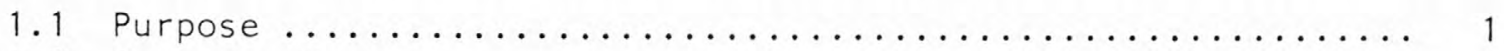

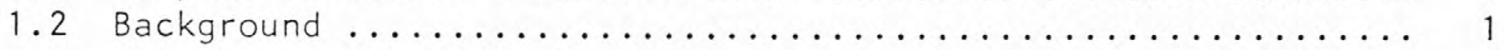

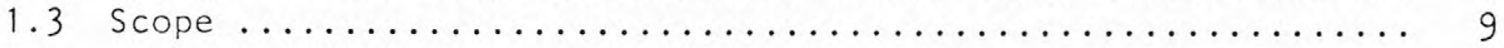

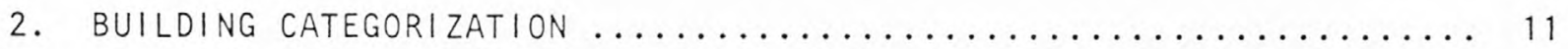

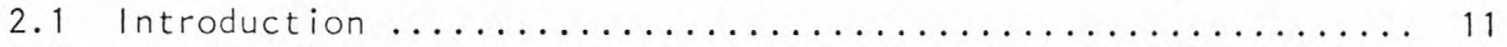

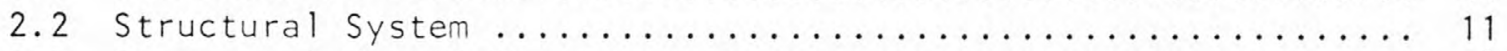

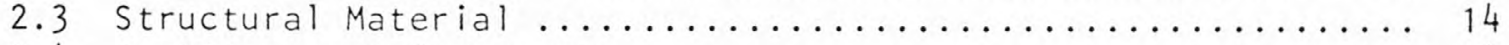

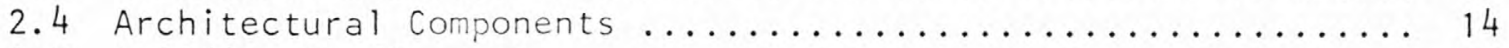

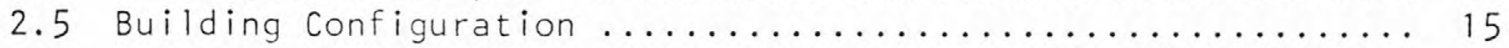

3. DATA COLLECTION AND DATA BASE MANAGEMENT $\ldots \ldots \ldots \ldots \ldots \ldots \ldots \ldots \ldots$

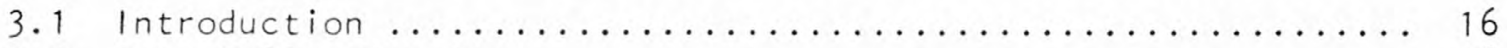

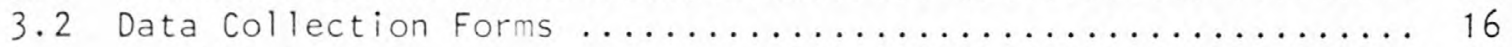

3.3 Earthquakes and Urban Areas Considered ................ 18

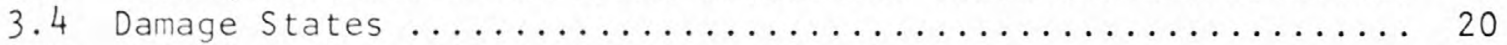

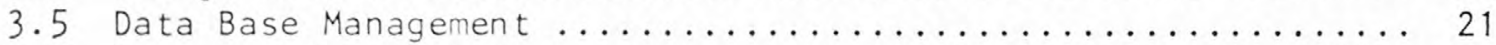

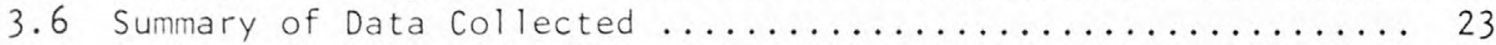

4. ESTIMATION OF ENGINEERING INTENSITY FROM SEISMOLOGICAL

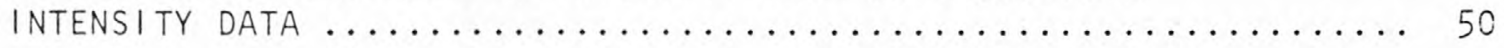

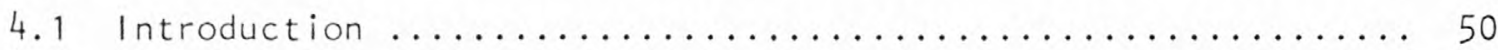

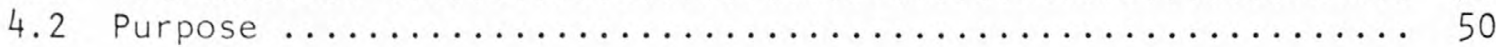

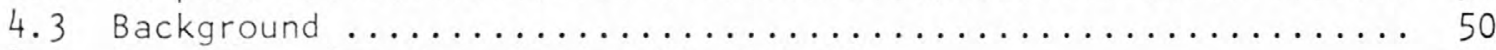

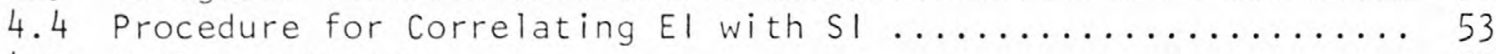

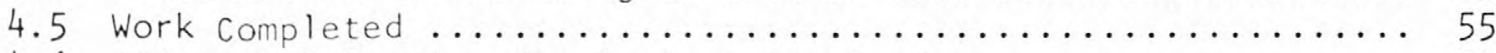

4.6 Additional Studies for Project Completion ............. 55

5. THEORETICAL MOTION-DAMAGE RELATIONSHIPS $\ldots \ldots \ldots \ldots \ldots \ldots$

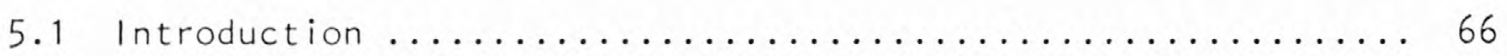

5.2 Detailed Response Analysis of Damaged Buildings .......... 67

5.3 Detailed Response Analysis of the Bank of California

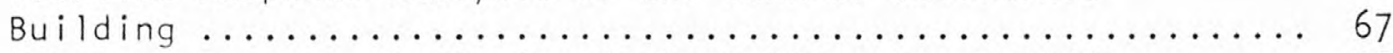

5.4 Detailed Response Analysis of the Holiday Inn Building ..... 75

5.5 Approximate Theoretical Motion-Damage Relationships ....... 77

5.6 Additional Studies for Project Completion ............ 82

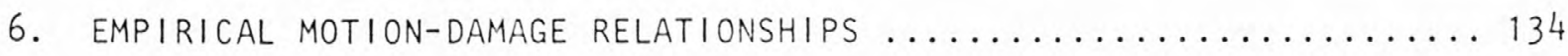

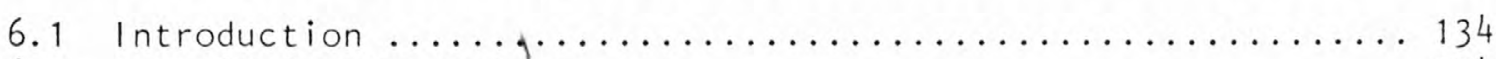

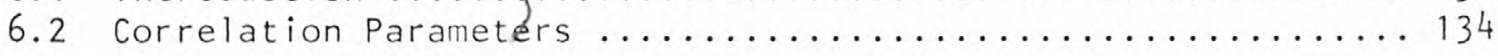




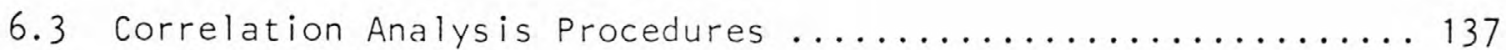

6.4 Additional Studies for Completion ................. 138

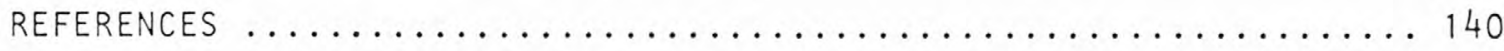

\section{APPENDICES}
A References for Data Collection
B Sample Listings of the HIRISE Data Base
C Seismological Intensity Scales
D Engineering Intensity Scale
E Review of Lognormal Distribution Used for Statistical Analysis of Response Spectra
F Damage Functions

\section{TABLES}

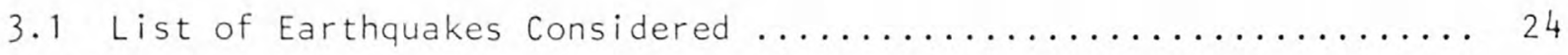

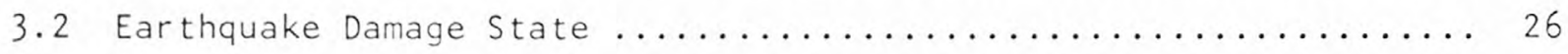

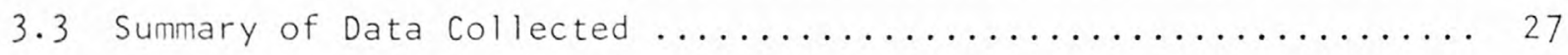

4.1 Correlation of MMI and EI Using Data from the 1971

San Fernando Earthquake - 5\% Damping, Lognormal Mean $S_{v} \ldots \ldots \ldots .57$

4.2 Correlation of MMI and EI Using Data from the 1971

San Fernando Earthquake - 5\% Damping, Lognormal 84th-

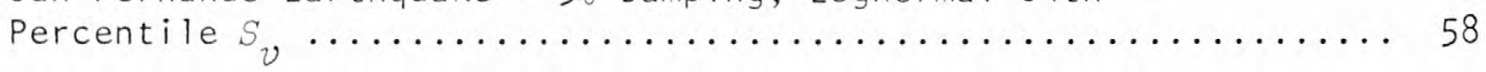

4.3 Strong-Motion Records Available on Magnetic Tape for

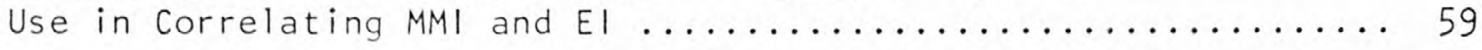

5.1 Bank of California Building - Properties of Concrete ........ 83

5. 2 Bank of California Building - Properties of Reinforcing Bars .... 83

5.3 Interstory Drift Limits for Various Structure Types .......... 84

5.4 Response Spectrum Displacements for Various Damage Thresholds

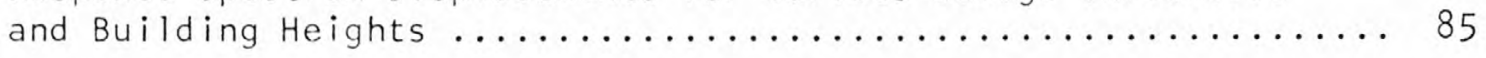

6.1 General Form of Damage Probability Matrix ............... 139 


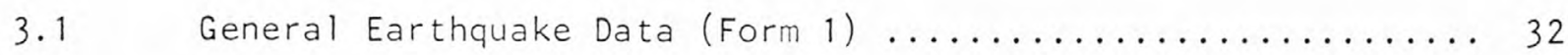

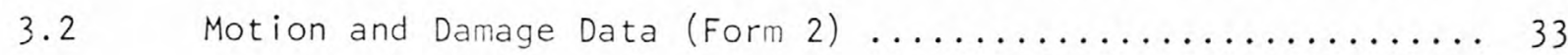

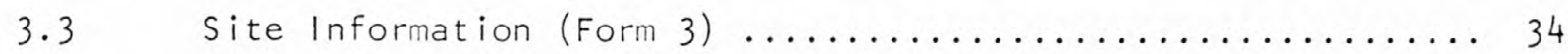

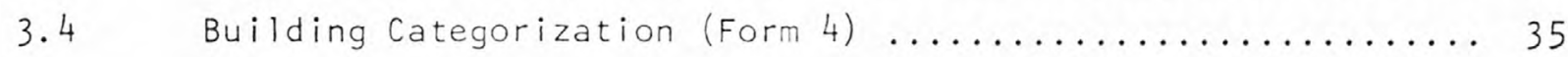

3.5 Detailed Site and Building Information (Form 5) $\ldots \ldots \ldots \ldots, 36$

3.6 Earthquake and Site Identification ..................... 37

3.7 Principal Earthquake Belts of the World ............... 38

3.8 Seismic/Geologic Structure of the Japanese Region ........... 39

3.9 Sample Damage-State Histogram .................... 40

3.10 Schematic Structure of Data-Base HIRISE $\ldots \ldots \ldots \ldots \ldots \ldots . \ldots 1$

3.11 HIRISE Data-Base Definition ...................... 42

3.12 General Earthquake Data (Form 1) .................. 46

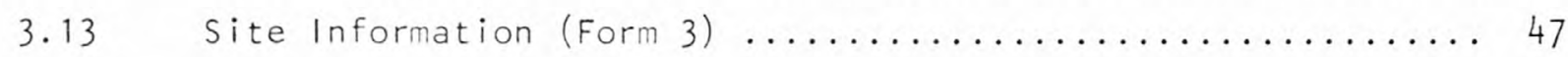

3.14 Building Categorization (Form 4) .................. 48

3.15 Motion and Damage Data (Form 2) ....................... 49

4.1 Predicted Spectral Pseudo Velocities for Earthquakes of Several Magnitudes and Distances $\ldots \ldots \ldots \ldots \ldots \ldots \ldots \ldots, 61$

4.2 Lognormal Mean Vertical Spectra for MMI V, VI, and VII

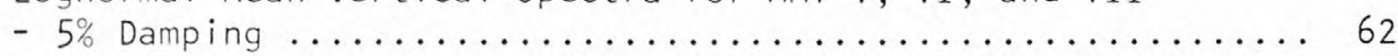

4.3 Lognormal Mean Horizontal Spectra for MMI V, VI, and

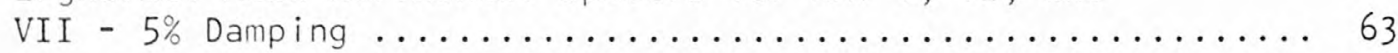

4.4 Lognormal 84th-Percentile Vertical spectra for MMI V, VI, and VII - 5\% Damping ............................ 64

4.5 Lognormal 84th-Percentile Horizontal spectra for

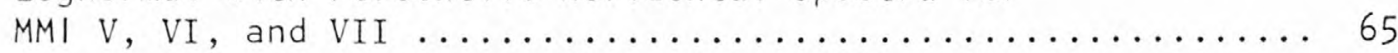

5.1 Bank of California Building: Ground-Floor Plan .......... 86

5.2 Bank of California Building: Second-Floor Plan ........... 87

5.3 Bank of California Building: Typical Floor Plan, Third through Twelfth Floors $\ldots \ldots \ldots \ldots \ldots \ldots \ldots \ldots . . . \ldots . \ldots . \ldots$

5.4 Bank of California Building: Typical Transverse Section and Structural Details ......................... 89

5.5 Typical Soil Boring Log at the Site of the Bank of California Building 
5.6 Shear Wave Velocity at the Site of the Bank of

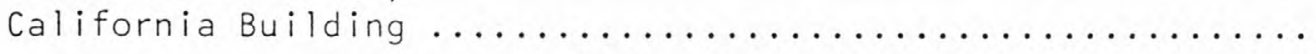

5.7 Bank of California Building, Ground Floor: Recorded Longitudinal Acceleration Time History and Associated

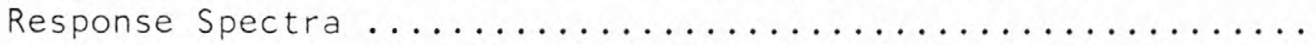

5.8 Bank of California Building, Ground Floor: Recorded Transverse Acceleration Time History and Associated

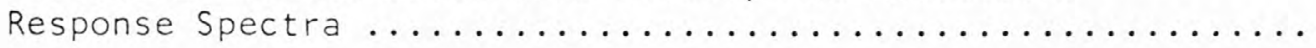

5.9 Bank of California Building, Ground Floor: Recorded Vertical Acceleration Time History and Associated

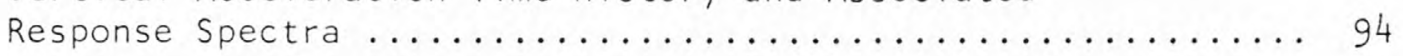

5.10 Bank of California Building: Fundamental Periods Obtained from Instantaneous Transfer Functions ............ 95

5.11 Bank of California Building: Change of Fundamental Periods During Earthquake Excitation .................... 96

5.12a-m Bank of California Building: Instantaneous Transfer Functions: Cases 1 through 7 and $A$ through $G \ldots \ldots . \ldots . . . . .97$

5.13a-c Model 1, Recorded and Theoretical Time Histories: Bank of California Building ...................... 110

5.14 Bank of California Building, Model 1: Structural

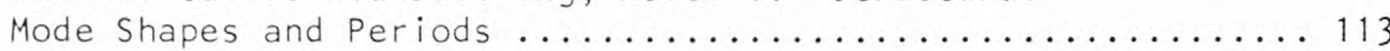

5.15 Bank of California Building: Longitudinal Frame on

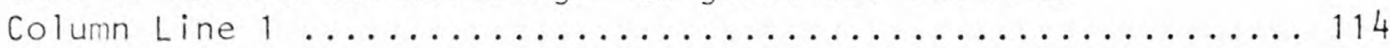

5.16 Bank of California Building: Longitudinal Frame on

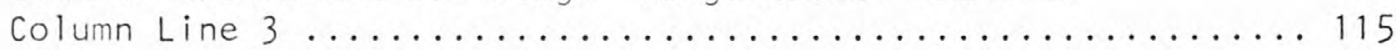

5.17 Bank of California Building: Transverse Frames on

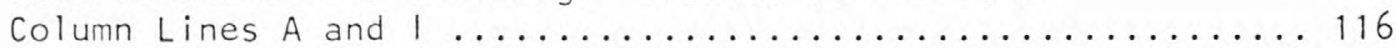

5.18a-d Model 2: Recorded and Theoretical Time Histories: Bank of California Building ....................... 117

5.19 Maximum Calculated Interstory Drifts for the Bank of California Building, Transverse Direction ................ 12

5.20 Average Interstory Drift: Bank of California Building, Transverse Direction, Model $1 \ldots \ldots \ldots \ldots \ldots \ldots \ldots \ldots 22$

5.21 Average Interstory Drift: Bank of California Building, Transverse Direction, Model $2 \ldots \ldots \ldots \ldots \ldots \ldots \ldots$

5.22 Orion Avenue Holiday Inn: Fundamental Periods Obtained from Instantaneous Transfer Functions, Longitudinal Direction ......................... 124

5.23 Orion Avenue Holiday Inn: Fundamental Periods Obtained from Instantaneous Transfer Functions, Transverse Direction 
5.24 Average Interstory Drift: Orion Avenue Holiday Inn,

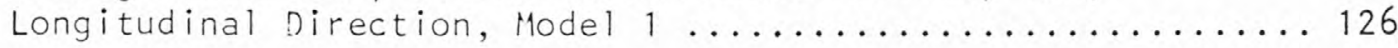

5.25 Average Interstory Drift: Orion Avenue Holiday Inn,

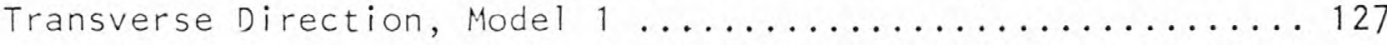

5.26 Average Interstory Drift: Orion Avenue Holiday Inn,

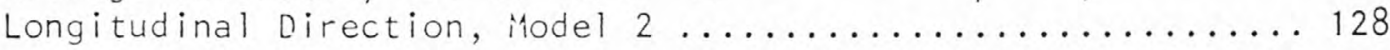

5.27 Average Interstory Drift: Orion Avenue Holiday Inn,

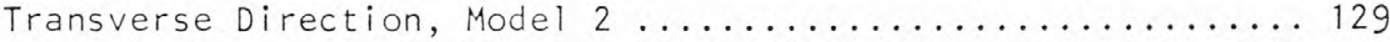

5.28 Maximum Calculated Interstory Drifts for Orion Avenue Holiday Inn, Transverse Direction ...................... 130

5.29 Maximum Calculated Interstory Drifts for Orion Avenue Holiday Inn, Longitudinal Direction ................. 131

5.30 Damage Prediction Using Structure Component Data ......... 132

5.31 Response Spectrum Amplitudes for Various Damage Thresholds for Reinforced Concrete Frame Structures ......... 133 


\section{ACKNOWLEDGMENTS}

This Annual Technical Report is the result of the efforts of investigators and staff of URS/John A. Blume \& Associates, Engineers. We would particularly like to acknowledge the contributions of the following individuals:

$\begin{array}{ll}\text { Project Direction } & \text { Roger E. Scholl } \\ \text { Internal Consultation } & \text { John A. Blume } \\ \text { Building Categorization } & \text { Kenneth K. Honda } \\ \text { Data Collection } & \text { Peter I. Yanev } \\ & \text { Cynthia L. Perry } \\ \text { Seismology } & \text { Jack M. Zanetti }\end{array}$


The problem considered in this project, conducted by URS/John A. Blume $\varepsilon$ Associates, Engineers (URS/Blume), for the U.S. Geological Survey, is the identification, evaluation, and correlation of ground-motion and structural parameters in order to improve procedures for predicting dollar losses for high-rise structures damaged by earthquakes. Ground-motion data bases, analytical techniques, and known motion-damage relationships already developed for high-rise buildings and for other classes of structures will be refined and extended so that reliable quantitative seismic risk evaluations can be made.

The research effort consists of three one-year phases composed of five major tasks, as follows:
Task I Data collection
Task II Building categorization and calculation of theoretical motion-damage relationships
Task III Estimation of engineering intensity from seis- mological intensity data
Task IV Evaluation of empirical motion-damage rela- tionships
Task V Correlations between theoretical and empirical motion-damage relationships

Task I was largely completed during the first year. Tasks II and JII were initiated during the first year and are scheduled to be completed during the third year. Task IV was initiated in the second year and is scheduled for completion in the third year. Task $V$ will be initiated and completed during the third year.

The objective of Task I was to establish a data base of worldwide seismic response and damage data for high-rise buildings. Only earthquakes that affected high-rise structures were selected for study. For convenience, the data collection effort was divided into the following regions: North America; Latin America; Europe and the Mediterranean; and the western Pacific, which includes Japan and New Zealand. 
Five different forms were developed to systematically collect the pertinent data. Form 1 provides general earthquake data; Form 2, motion and damage data; Form 3, site information; Form 4, building categorization; and Form 5, detailed site and building information, such as test boring logs or design calculations. The collected data that are essential for the completion of the project include strong ground-motion parameters, soil characteristics, estimated damage, design parameters, building categorization, and geographical location. In addition, seismological data, construction practices, and other general information has been collected for selected areas.

A data-base system, called data base HIRISE, has been established using the information collected in the forms and computerized. The data base facilitates the access and retrieval of data in any order or arrangement desired, thus simplifying the correlation studies.

The building categorization included in Task II has been completed. Structural systems considered in this categorization are foundation systems, vertical-load-support systems, lateral-load-resisting systems, and floor systems. The most important of these are the lateral-load-resisting systems. The structural and architectural materials used in the construction of buildings are also considered. Architectural materials, although not designed specifically to resist the lateral loads, contribute in varying degrees to this resistance and are important for damage evaluation. The degree of contribution depends not only on the type of architectural material used but also on the framing characteristics of the building system. Building configuration is important because irregularity in building plan and elevation may result in torsional response. Torsional response may also occur because of eccentric location of either the building masses or the lateralload-resisting elements. Data collection Form 4 was developed to appropriately record each of these items for the categorization of buildings.

Another facet of Task II is the establishment of theoretical motion-damage relationships. Individual buildings damaged by the San Fernando earthquake are being analyzed in detail, and damage estimation procedures based on interstory drift and ductility are being developed and tested. The Bank of California Building and two Holiday Inn buildings are currently under study. Significant progress has been realized in the analytical identification of 
damage threshold and in the values of various response parameters at this level of response for the buildings. High correlation has been obtained between interstory displacement and threshold damage.

The basic concepts for prescribing theoretically based motion-damage relationships have been established and are being implemented. The major work remaining is that of extracting structure component test data from the literature and documentation.

In Task III, substantial progress has been made toward relating seismological intensity to engineering intensity.* Initial results based on published data from the 1971 San Fernando, California, earthquake have been compiled, and some conclusions have been drawn. It is evident, for example, that further consideration should be given to seismological and geological factors such as distance, magnitude, and local geology; as the investigation continues, more data will be used to check the relationships among these factors. URS/Blume has acquired an extensive data base of 281 (3-channel) strongmotion records from earthquakes throughout the world; these will be used to extend the conclusions concerning relationships between engineering intensity and seismological intensity.

In Task IV, various empirically derived motion-damage relationships will be developed from data base HIRISE. The principal indicators of damage to be calculated will be the Damage Factor (DF), defined as the ratio of dollar damage to replacement value, and the Damage Ratio (DR), defined as the ratio of the number of buildings damaged to the total number of buildings in a given area. These damage parameters will be correlated with motion identified in terms of Engineering Intensity Scale (EIS) level. Finally, these empirical motion-damage relationships will be calculated for various building categorizations -- including subclasses for various types of structural and nonstructural components -- as the available data permit.

\footnotetext{
*Engineering intensity implies a measure of ground shaking that is useful for performing engineering analyses and is readily interpretable for designing structures. A detailed description of the Engineering Intensity Scale that is used to characterize ground motion is given in Appendix D.
} 


\section{INTRODUCTION}

\subsection{Purpose}

The problem considered in this project, which is being conducted by URS/ John A. Blume \& Associates, Engineers (URS/Blume), for the U.S. Geological Survey (USGS), is the identification, evaluation, and correlation of ground motion and structural parameters in order to improve procedures for predicting dollar losses in high-rise structures damaged by earthquakes. Ground motion data bases, analytical techniques, and known motion-damage relationships already developed for high-rise buildings and for other classes of structures are being refined and extended so that reliable quantitative seismic risk evaluations can be made.

\subsection{Background}

Several methods for predicting damage to structures due to ground vibrations have been developed and described by various investigators for such purposes as seismic design optimization, earthquake insurance considerations, predicting the effects of underground nuclear explosions on man-made structures, and earthquake hazard reduction.

One such method for estimating earthquake-induced economic losses to woodframe dwellings in California, described by Steinbrugge et al. (1969), was developed to aid in analyzing the feasibility and effectiveness of earthquake insurance.

This method uses the modified Mercalli intensity (MMI) scale to describe the intensity of ground motion. For a given earthquake, such as the maximum credible earthquake, empirical isoseismal maps are developed. These maps consider the rupture of the fault (hence, the ellipticity of the isoseismals) and the empirical relationship between magnitude and MMI. The area enclosed within a given MMI isoseismal line is also determined from empirical data, as a function of magnitude. Because MMI is used to represent the ground motion intensity, and MMI is directly related to damage, no structural response calculation is done. 
Damage to wood-frame dwellings is estimated by four components: structure, interior finish, exterior finish, and chimney. These are further subdivided to account for major variations within a component. One possible way of subdividing is by age. For each damage component, the degree of damage is described by such terms as slight, moderate, severe, and total loss.

The relationship of MMI to degree of component damage is estimated by earthquake professionals from limited available data. These MMl-damage relationships are converted into relationships of MMI to repair cost, again by estimates made by professionals.

In order to predict losses to wood-frame dwellings within a region, the region under consideration is divided into standard location areas (SLAs). For a given earthquake, MMI intensities are estimated for each SLA. Then, losses for each SLA are calculated by using the intensity-loss relationships. Characteristics of the structure population within each SLA (inventory data) are derived mainly from data from the United States Bureau of the Census.

The method is a good one for the type of building for which it is intended. The sources of information identified are of great value for similar future studies. However, the method requires a great deal of expertise that can only be provided by professionals from such diverse fields as engineering, statistics, and insurance. Also, the method cannot be applied to high-rise structures without modifications that are so extensive that they should lead to the development of a completely independent method.

Studies have been performed to improve Steinbrugge's method and to apply it to other types of structures. Rinehart et al. (1976) have performed a sensitivity analysis to determine the relative significance of various parameters with respect to losses. This analysis has led to improvements in the method.

Algermissen et al. (1978a) extended the previous work to cover buildings other than a single-family dwellings. In this study, a building inventory methodology was formally introduced. A building classification, not necessarily related to engineering design parameters, was adopted from the Insurance Services office (ISO) system, and used in the method. 
Based on their previous work, Algermissen et al. (1978b) developed a technique for rapid estimation of earthquake losses. This method entails the development of a series of maps showing contours of percent losses to specific building types for each MMI level. The method could be valuable for quick postearthquake loss estimates; however, the necessary data must be collected and processed before such an earthquake, and experts with specific understanding of the method must be available.

Another method is described by Culver et al. (1975) for survey and evaluation of existing buildings, to determine the risk to life, and to estimate the amount of expected damage. In this method, damage to both structural and nonstructural building components resulting from the extreme natural environments encountered in earthquakes, hurricanes, and tornadoes is considered. The method can treat a large class of structural types, including braced and unbraced steel frames, concrete frames with and without shear walls, bearing wall structures, and long-span roof structures. Three independent but related sets of procedures for estimating damage for each of the natural hazards are included. The first set of procedures (called the Field Evaluation Method) provides a means for qualitatively determining the damage level on the basis of data collected in field surveys. The second set (the Approximate Analytical Evaluation Method) uses a structural analysis of the building to determine the damage level as a function of the behavior of critical elements. The third set (the Detailed Analytical Evaluation Method) is based on a computer analysis of the entire structure. The procedures are presented in a format that allows updating and refining.

The Field Evaluation Method and the Approximate Analytical Evaluation Method do not estimate the extent of damage quantitatively. In the Detailed Analytical Evaluation Method, the ground motion at a site is expressed in terms of a site particle velocity spectrum, which is obtained by multiplying a hard-rock velocity spectrum by an appropriate soil amplification factor. Alternative procedures are described for obtaining the hard-rock velocity spectrum and the soil amplification factor for a given site.

A response spectrum approach with provisions for amplitude-dependent damping and stiffness characteristics is suggested for calculating the structure's response to the prescribed ground motion. The response parameters used 
in predicting damage are maximum floor accelerations, floor velocities, and interstory displacements. Three types of damage, namely, structural, nonstructural partition, and nonstructural window damage are related to these parameters. Structural damage and window damage are assumed to be a functions of interstory drift, whereas nonstructural partition damage is assumed to be related to the maximum floor velocity and acceleration.

The relationship between the percentage of structural damage at a given story level and the maximum drift at that level is assumed to be a normally distributed curve defined by a mean ductility to failure and an associated coefficient of variation. Ductility to failure is determined empirically, and professional judgement is exercised in selecting the proper coefficient of variation.

Nonstructural damage at a floor level is estimated by treating that level as a site on the ground subjected to an effective floor modified Mercalli intensity, $I_{i} \quad I_{i}$ is empirically related to maximum floor acceleration and velocity. The relationship between $I_{i}$ and the percentage of nonstructural damage to the floor is also given by an empirical formula, which includes a parameter called Quality Factor, reflecting the damageability of the specific construction type.

The relationship of story drift to glass damage is treated in a similar manner to structural damage, with a defined drift-to-failure value, an associated coefficient of variation, and assumed normal distribution.

The method attempts to relate engineering parameters to the extent of damage suffered by the components of a given structure. However, damage is expressed in percentage only and is not related to monetary loss.

An extensive program has been undertaken at Massachusetts Institute of Technology, led by R. V. Whitman, J. M. Biggs, C. A. Cornell, and E. H. Vanmarcke, to develop a method named Optimum Seismic Protection and Building Damage Statistics. The title was later changed (Whitman, 1973) to Seismic Design Decision Analysis (SDDA). To select the level of seismic resistance to be required for an individual structure or a group of structures, the SDDA considers the cost of providing increased seismic resistance, the damage that may occur 
during future earthquakes, and the human and social consequences of such damage.

Many studies have been performed and reports published as part of the SDDA program. A description of the program as originally conceived is given in Report No. 1 (Whitman et al., 1972). Theoretical structure response studies are reported in Reports No. 3 and No. 4 (Anagnostopoulos, 1972; Biggs and Grace, 1973). Damage data and statistics obtained from the 1971 San Fernando, California, earthquake are reported in Report No. 7 (Whitman et al., 1973). Report No. 8, by Whitman (1973), gives damage probability matrices for multistory buildings. Two reports attempt to correlate earthquake damage to tall buildings with strong ground motion parameters (Wong, 1975; Whitman et al., 1977). And in Report No. 30, Schumacker and whitman apply the methods developed to the estimation of losses to cities and regions.

Czarnecki (1973) has developed a damage-prediction method, as part of MIT's SDDA program, that is based on engineering principles and is oriented toward high-rise building structures. In this method, the damage is related to the structural response parameters. The building can be analyzed for a given earthquake using any acceptable dynamic analysis technique, such as response spectrum analysis or linear or nonlinear time-history analysis. Total damage to a given building is classified into components. Components suggested for high-rise buildings are structural damage (damage to steel frames, concrete frames, braced frames, shear walls), nonstructural damage (damage to drywall partitions, exterior glazing, brick masonry walls, concrete block walls), and other damage. Structural damage is fully attributed to the vertical structural elements, i.e., columns, shear walls, etc., and is assumed to be proportional to the inelastic energy absorbed by that element. Nonstructural damage is associated with maximum interstory drift. Drift-damage curves are developed based on actual data and engineering design practices. No attempt is made to consider the variabilities of the parameters used in the damage prediction or of the final results.

Three distinct methods for predicting damage to structures due to large underground nuclear explosions, that are equally applicable to predicting damage due to earthquakes, have been developed and described by Blume. These three methods -- the Engineering Intensity Scale, the Spectral Matrix Method, and 
the Threshold Evaluation Method -- provide a means for making progressively more detailed predictions of structural effects due to seismic motions.

The Engineering Intensity Scale (EIS) method (Blume, 1970) is used to estimate the extent of the area in which structures might be damaged and to make a general evaluation of the incidence and degree of damage to structures within that area.

In the formulation of the Engineering Intensity Scale, ground motion is characterized by $5 \%$-damped spectral velocity $\left(S_{v}\right)$, and structures are characterized by their fundamental-mode vibration properties. Neglecting mode shape considerations, the important correlation variables for relating motion and damage are $S_{v}$ amplitude and building period. The 5\%-damping value is used because damping in many real structures varies from about $2 \%$ to $10 \%$, and $5 \%$ has been made a standard reference level in the nuclear event structural response program conducted by URS/Blume for the Nevada Operations Office of the U.S. Department of Energy.

Engineering intensity (EI) numbers are assigned to various spectral velocity bands. The applicable range of spectral velocities $\left(S_{v}\right)$ and periods (T) applicable to civil engineering structures is divided into a 10 by 9 matrix with ten intensity levels, from 0 through 9 , and nine period bands, I through IX, in the period range from $0.01 \mathrm{sec}$ to $10 \mathrm{sec}$.

A significant amount of data on ground motion caused by underground nuclear explosions and corresponding damage data have been available for establishing the incidence and degree of damage for various EI ranges for low-rise buildings (Hafen and Kintzer, 1977; URS/Blume, 1975). In addition, motion and damage data from the 1971 San Fernando earthquake for low-rise (Hafen and Kintzer, 1977; Scholl, 1974) and high-rise (Hafen and Kintzer, 1977; Wong, 1975) buildings are available. Motion-damage relationship information for highrise buildings from Whitman et al. (1977) and the additional correlation work currently in process at URS/Blume will provide sufficient information for this class of buildings. 
The Spectral Matrix Method (SMM) has been in continuous development and use by URS/Blume since 1966. The earliest version was presented in January 1967 (Blume, 1967). The method has subsequently been simplified and further developed (Blume, 1968; Blume and Monroe, 1971; URS/Blume, 1975).

The method is a generalized, statistical, computer-based procedure developed for the purpose of quantitatively predicting damage on a large scale. That is, the procedure is applicable to predictions involving a large number of structures, including structures of several different classes and types. A fundamental philosophy of the procedure is that both structure resistance (capacity) and ground motion (demand) are random variables, and damage prediction therefore becomes a problem of joint probabilities.

The most important element in the SMM procedure is the evaluation of the damage factor (called damage ratio by some investigators) as a function of motion amplitude. The damage factor is defined as the ratio of dollar damage for a building to the building's replacement value. Appropriate damage factor models can be obtained directly from experimental motion-damage relationship investigations or indirectly from theoretical considerations. The damage factor model in the SMM is theoretically derived. Five fundamental structurebased parameters are included in the theoretical damage factor model in order to take best advantage of available structure-element test data and thus to facilitate application of the procedure to predictions involving structures for which no empirical motion-damage relationship data exist. Specifically, for predicting building damage caused by ground motion, the method considers the following factors:

- Amplitude and frequency distribution of ground motion

- Foundation conditions

- Elastic strength, capacity, and damping of structures

- Inelastic reserve strength of structures for dissipating excess demand of communicated energy

- Probabilistic evaluation of the random variables inherent in the prediction problem

While the SMM procedure is theoretically based, it is essential that the procedure be calibrated. jubstantial low-rise building motion and damage data 
from underground nuclear explosions (URS/Blume, 1975) and some data from earthquakes (URS/Blume, 1975; Scholl, 1974) have been used for this purpose.

The Threshold Evaluation Method (TEM, Blume, 1969) for predicting the effects of dynamic ground motion on structures involves a systematic and detailed dynamic structural analysis of individual structures. This method is used to identify both the potential risk from a structure's failure and modifications that might improve the resistance of that structure to structural failure caused by ground motion. Basically, the TEM is an extension of conventional structural analysis procedures used in design. It requires the identification of various capacity thresholds and the evaluation of the probability of exceeding these thresholds for a given seismic event. It is intended to provide detailed insight into the structural behavior of an individual building under lateral loading and to take advantage of several mitigating factors that are normally ignored in structural design practice in the interests of providing additional margins of safety.

A fundamental step in conducting a threshold evaluation analysis is to develop a mathematical model of the building. Because the TEM considers both elastic and inelastic response, it is usually desirable to develop at least two mathematical models. The frequencies and mode shapes obtained from the mathematical model are used to estimate the response spectrum demand amplitude.

A capacity threshold is defined as the total lateral load that would be required to cause a building to reach a specified level of behavior. For example, a code-required threshold is the base shear coefficient required by an applicable building code. Similarly, a yield limit threshold is the smallest base shear coefficient causing a significant structural member to reach yield stress.

With this information, the probability of exceeding the various capacity thresholds for a particular seismic response spectrum can be evaluated. The significance of a high probability of exceedance depends on the threshold and the severity of the demand spectra being considered. For example, a high probability of exceeding the yield limit or observable damage threshold for a seismic event that is likely to occur several times during the building's useful life may be an unacceptably high risk. However, for the maximum 
credible seismic event, it may be acceptable to exceed all thresholds except story failure.

\subsection{Scope}

To improve quantitative reliability and to refine earthquake damage prediction procedures for high-rise buildings, URS/Blume is conducting in this project an extensive collection and correlation analysis of worldwide seismic response and damage data for high-rise buildings, related earthquake ground motion data, intensity estimates, and structural response information. Pertinent experimental building response and damage data are being investigated as well. Empirical motion-damage relationships will be calculated, and theoretical analyses will be conducted to establish motion-damage relationships for various types of high-rise buildings. The theoretical analyses will be based on engineering fundamentals of dynamic response prediction and on available structure component damage criteria and will be used to assess and to aid in substantiating the empirically derived relationships. Finally, studies will be undertaken to correlate the assembled empirical data with the theoretically derived models of structure damage. These correlation studies will aid in establishing damage prediction reliability and in identifying future research needs.

Specifically, the research consists of three one-year phases made up of five major tasks, as follows:

Task I $\begin{aligned} & \text { Data collection. } \\ & \text { Task II } \\ & \text { Building categorization and calculation of } \\ & \text { theoretical motion-damage relationships. }\end{aligned}$
Task III $\begin{aligned} & \text { Estimation of engineering intensity from } \\ & \text { seismological intensity data. }\end{aligned}$
Task IV $\begin{aligned} & \text { Evaluation of empirical motion-damage rela- } \\ & \text { tionships. }\end{aligned}$
Task $V \quad \begin{aligned} & \text { Correlations between theoretical and empiri- } \\ & \text { cal motion-damage relationships. }\end{aligned}$

Task I was largely completed during the first year, but data collection is continuing to make the data base more complete. Tasks II and III were initiated during the first year and are scheduled to be completed during the third year. Task IV was initiated during the second year and is scheduled to be completed during the third year. Task $\mathrm{V}$ will be initiated and completed during 
the third year. This report summarizes progress made in the first and second years. 


\section{BUILDING CATEGORIZATION}

\subsection{Introduction}

As a part of the data collection effort, information about earthquake effects on buildings and the relevant characteristics of affected buildings has been collected. Once this information is evaluated, empirical motion-damage relationships can be developed.

Four major building features considered in the categorization are: structural system, structural material, architectural material, and building configuration. Each of these categories is subcategorized to identify unique features of each building. This categorization scheme is the basis for Data Collection Form 4, which is discussed in Chapter 3.

\subsection{Structural System}

The structural system comprises the basic elements of the building. These elements include the foundation that supports the building against the action of the vertical (gravity) load and transmits the inertial forces generated in the building by seismic action to the foundation material, the vertical-load-support system that is designed to support the vertical load of the building and to transmit the load to the foundation, the lateral-loadresisting system that transmits lateral loads such as earthquake-generated inertial forces to the foundation, and the floor system (including the roof system) that transmits both vertical and horizontal loads to the adjoining framing system.

\subsubsection{Foundation. The function of the foundation is to transmit vertical} and horizontal loads from the building to the soil foundation material. The type of foundation depends on the structural system and the foundation material. Wall footings distribute the wall loads to the soil foundation and are continuous along the wall. Spread footings distribute the load from individual columns. Often, as a result of space limitations or column spacing, more than one column is supported by a footing. This is referred to as a combined footing. When more than one spread footing is combined or connected by a beam, it is referred to as a strap footing. A raft or mat foundation is essentially a large combined footing: the entire foundation below the building 
consists of a single footing. Depending on the quality of the foundation material, it is sometimes necessary to provide additional means to support the building load. This is provided by piles or caissons. The piles are driven into the ground, and the load is transferred from a column to the piles by footings. Caissons perform functions similar to those of piles. It is possible for a building to have a combination of the foundation types described above.

2.2.2 Vertical and Horizontal Load-Support Systems. In the design of most buildings, the elements that support the vertical and horizontal loads are treated independently. For some buildings, certain elements are designed specifically to support only the gravity load or to support only the seismic load. Some elements, however, are designed to support both loads. For this reason, these two systems are discussed under one heading.

Buildings are composed of vertical and horizontal structural elements that resist internal and applied forces. The forces originating from the mass of vertical elements are transferred either directly to the ground, as in the case of vertical cantilevers, or to horizontal resisting elements other than the ground through vertical beam action of the vertical elements. The forces originating from the mass tributary to the horizontal elements are distributed by these horizontal elements to vertical elements that, in turn, transmit the forces to the ground. Vertical elements used to transfer lateral forces to the ground are moment-resisting space frames, shear walls, and braced frames.

A space frame is a three-dimensional structural system, without bearing walls, composed of interconnected members laterally supported so as to function as a complete, self-contained unit with or without the aid of horizontal diaphragms or floor-bracing systems. Horizontal forces at any floor or roof level are transmitted to the soil foundation by the strength, rigidity, and ductility of the space frame. A space frame depends on its own bending stiffness for the lateral stability of the structure. A moment-resisting space frame is a vertical-load-carrying space frame in which the members and joints are capable of resisting design lateral forces by bending moments at beam-column connections. 
Walls may be subjected to both vertical and horizontal forces. A wall carrying a vertical load other than its own weight is called a bearing wall. The horizontal forces acting on a wall may be either normal to the wall or parallel to the wall. A shear wall resists horizontal forces parallel to the wall. Any wall or partition that carries a vertical load other than its own weight or that resists a horizontal force parallel to the wall is classified as a structural wall. Sometimes these walls are arranged around stairs and elevators to form a box. This system is called a shear core, and it acts to resist the seismic load not only parallel to the walls, but perpendicular to the walls as well. It can be visualized as a huge box cantilevered out of the ground.

Braced frames are sometimes used in place of shear walls to resist lateral forces. The material may be reinforced concrete, structural steel, or wood. Vertical bracing systems are used to transfer the horizontal forces at the floor or roof levels to the foundation. The function of the bracing is to resist forces that tend to deform the building in the direction parallel to the plane of that bracing and to transmit these lateral loads to the foundation.

Buildings may use both shear walls and moment-resisting space frames to resist lateral forces. The contribution of the frame to the resistance of lateral forces is that it will provide redundancy and a reserve strength against complete collapse if the shear walls should fail.

Similar to using a shear core in place of shear walls, an entire building can be constructed to act as a cantilever beam. Lateral load is resisted not only by frames or walls parallel to the load but also by the frames and walls perpendicular to the load through the interaction of these elements.

2.2.3 Floor System. Horizontal forces produced by seismic motion are proportional to the masses of building elements involved and originate at the centroid of mass of these elements. The forces originating at masses tributary to the horizontal elements are distributed by these horizontal elements to vertical elements that, in turn, transmit the forces to the ground. 
Forces may also be transmitted from vertical elements to horizontal elements and then be redistributed to other vertical elements. Horizontal forces at any floor or roof level are distributed to the vertical resisting elements by mobilizing the strength and ridigity of the floor or roof deck as a diaphragm. Horizontal bracing may be used in place of diaphragms. A diaphragm may be considered analogous to a plate girder or shear wall in the horizontal (or inclined, in the case of the roof) plane; the floor or roof deck performs the function of the plate girder web, the joints or beams function as web stiffeners, and the peripheral beams or integral reinforcement functions as flanges. A diaphragm may be constructed of materials such as concrete, wood, or metal. Combinations of materials are possible.

\subsection{Structural Material}

The structural materials considered in building categorization are those used in the construction of the structural system. Materials used in the construction of buildings are an important part of the total evaluation since the response characteristics of the buildings are influenced not only by the structural framing systems but also by the strength and deformation characteristics of the material. Different materials also influence the possibility and the amount of damage to the buildings.

\subsection{Architectural Components}

Architectural components in a building include all elements of a building that are not explicitly considered in the design of the building as either vertical- or lateral-load-carrying members. These include such elements as interior partitions and exterior cladding. Although not designed specifically to resist the lateral loads, architectural components contribute in varying degrees to this resistance and are important for evaluations of damage. Their contribution depends not only on the type of architectural component used, but also on the framing characteristics of the building systems.

The damage to architectural components on a stiff shear-wall building would normally be less than the damage to these components on a flexible frame building if both buildings were subjected to an equal lateral force level. Thus, architectural component damage factors for a frame building and a shear-wall building would also differ. Regardless of the level of ground 
motion, the frame building would have a higher proportion of architectural damage than would the shear-wall building.

\subsection{Building Configuration}

Any irregularity in building response or torsional response may result in localized damage. Irregularity in response may be caused by discontinuity or a major shift in the load distribution path, construction variabilities, or nonsymmetry in configuration. Torsional response may result from marked asymmetry in stiffnesses and masses. Most building codes reflect recognition of irregularities in design configuration and require corrective action for design. 


\section{DATA COLLECTION AND DATA BASE MANAGEMENT}

\subsection{Introduction}

Task I involves the collection of information about earthquakes and building damage caused by earthquakes. This information will be used as a basis for the analyses to be performed in the second and third phases of the project. specifically, this information will be used for calculating empirical motiondamage relationships for high-rise buildings.

The principal information to be collected for developing empirical motiondamage relationships includes descriptions of: the earthquake shaking, the structure involved, and the damage incurred. This information can be collected with varying degrees of detail. Since the ultimate objective of this study is to develop both empirical and theoretical motion-damage relationships for high-rise buildings and because it is intended that the information collected be useful for any of the contemporary damage prediction procedures (see Chapter 1), it was decided that the data collection should be as comprehensive as possible. Accordingly, five data collection forms were developed to record the pertinent data. These are discussed below in section 3.2. The earthquakes and urban areas included in the data collection effort are described in Section 3.3. To manipulate, and thus facilitate analyzing, the substantial volume of data collected, a data-base-management system has been used; this system is described in Section 3.5 .

A list of the references searched thus far in collecting the data is given in Appendix A.

\subsection{Data Collection Forms}

Five data collection forms were designed to separate earthquake-dependent data from a general description of each high-rise building and its site. These forms are:

- Form 1: General Earthquake Data

- Form 2: Motion and Damage Data

- Form 3: Site Information

- Form 4: Building Categorization 
The blank forms are reproduced in Figures 3.1 through 3.5 .

The identification numbers placed on each form are described in Figure 3.6. The "Earthquake ID" includes an abbreviated name, the month and year of occurrence, plus a letter to indicate aftershocks. For example, ROM-03-77 identifies the main shock of the Romanian earthquake on March 4, 1977. The "Site 10 " includes both a country and city designation plus four additional characters to indicate whether there is a building or ground station at the site. An uninstrumented building in Anchorage, Alaska, would have a site ID of USA-ANC-B501.

General earthquake data, such as magnitude, maximum intensity, epicentral location, and estimated damage, are given on Form 1. A separate form is used to give basic information about significant aftershocks, but generally the earthquake effects and damage estimates are combined and given for the main shock only.

Form 2 lists motion and damage data at each site for a particular earthquake. In an area of high seismicity, a given building may have sustained damage in several earthquakes, requiring a separate form for each. Only Section 2.1 of the form on motion data is relevant to ground motion stations, but all the items apply to building sites. The damage summary is divided between primary and secondary damage. Structural and architectural damage are considered primary effects; secondary effects include casualties and mechanical failure. When a detailed damage description is available, it is attached using Form 5 .

General site information is given on Forms 3 and 4 . For ground motion stations, only the site geology on Form 3 is required. For building sites, the geology data, as well as building design and construction data, are given on Form 3. Each building is classified according to its structural system, materials, configuration, and foundation type on Form 4 . The building categorization scheme was described in Chapter 2.

Two columns are provided at the right margin of Forms 1 through 4 . A check mark in the column headed "Details Attached" indicates that further details 
are available and are labeled with the same ID numbers and attached using Form 5. A separate reference list is used for each of the four regions discussed in Section 3.3.

\subsection{Earthquakes and Urban Areas Considered}

Earthquakes occur most frequently along several belts that form the interfaces between major tectonic plates. The areas of highest seismicity are along the Circum-Pacific Belt, which encircles the Pacific Ocean, and along the Alpide Belt in the Mediterranean and trans-Asiatic zone. These belts can be seen in the world seismicity map in Figure 3.7.

This investigation considered only those earthquakes that affected highrise buildings in urban areas. Using this criterion, all the earthquakes selected were grouped into one of the following regions: North America; Latin America; the Mediterranean section of the Alpide Belt; and the western branch of the Circum-Pacific Belt, which includes Japan and New Zealand. These regions were chosen more for convenience than because of any earthquake engineering considerations.

Among the criteria used to select the earthquakes were peak ground acceleration, maximum intensity, number of high-rise buildings affected, extent of damage, and availability of information. It is difficult to quantify these criteria and establish an overall standard because the characteristics of damaging earthquakes are different in each region. The extent of damage depends on many parameters, including the design, construction, age, and condition of the affected buildings; the geological and foundation conditions; and the magnitude and duration of motion. For example, a magnitude 6.0 shock might cause extensive damage in a poorly constructed city but little or no damage in an area where the lateral force requirements are very stringent. A description of the salient features of the earthquakes selected and the specific criteria used for each region are included in the sections that follow. Table 3.1 provides a list of the earthquakes initially considered for all the regions.

3.3.1 North America. The earthquakes selected in North America all occurred in the western United States, including Hawai i. Each earthquake affected 
high-rise buildings in one of the following urban areas: Southern California; San Francisco Bay Area, California; Puget Sound, Washington; or Anchorage, Alaska. These regions are only loosely defined. Each may include several major cities and take in a large land area.

All of the earthquakes chosen had a Richter magnitude greater than 4.0 and an MMI of $V$ or greater. Because of the lack of instrumental data near the epicenters or fault breaks, no specific cutoff was used for peak ground acceleration. Other criteria, such as the availability of ground motion and building response records and damage descriptions, were also used. In addition, the proximity of an earthquake to one of the four urban areas mentioned was considered. Several low-magnitude earthquakes were chosen to establish a damage threshold, while others were chosen to provide information on cumulative damage to buildings in a particular area. Each one of the earthquakes chosen adds something to the data base on high-rise building performance.

\subsubsection{Latin America. Selection of Latin American earthquakes, which was} based on the extent of damage and the availability of data, was largely subjective. Form 1 was completed only when sufficient information was available. No specific cutoffs were used in the selection process, but generally both the Richter magnitudes and the MMI ratings were five or greater. Lack of instrumental data and the wide variation of ground-motion periods made it impossible to establish a cutoff for peak ground acceleration. A number of the earthquakes were included just to indicate the extent of seismic activity at each site and to allow a damage comparison to be made. The quality of available data and the possibility of gathering future seismic data from existing instrumentation were also considered in the selection process.

3.3.3 Europe and the Mediterranean. The most destructive of the recent earthquakes in this region are listed in Table 3.1. Although none of these are considered great earthquakes, they have caused extensive damage and loss of life. Magnitudes are typically 6.0 or 7.0 on the Richter scale, with MMI ratings ranging from VIII to $x$. The shallow focus of these shocks, the extensive use of unreinforced masonry, and the poor quality of construction all contributed to the high level of damage. 
3.3.4 Western Pacific Region. The earthquakes selected in the western Pacific region all occurred in either Japan or the Philippines. Most of these earthquakes were centered in the portion of the Circum-Pacific Belt that borders Japan.

The fault system near Japan is well defined because many earthquakes occur in this region. Off the coast of Honshu, the largest of the Japanese islands, the Circum-Pacific Belt branches into two distinct faults, as shown in Figure 3.8. One section branches southward toward the Marianas, and the other section stretches to the southwest through Kiushiu to Taiwan (Gutenberg and Richter, 1965). These faults outline the subduction zone where the Pacific Plate is moving under the Eurasian and Philippine plates. The fault slopes westward underneath mainland Japan at approximately $30^{\circ}$. Epicenters under Japan, therefore, are typically at a considerable depth. There are also two belts of deep-focus shocks. One crosses Japan transversely, and the other extends from llanchuria across southern Sakhalin into the Sea of okhotsk.

The National Research Center for Disaster Prevention started publishing StrongMotion Earthquake Records in Japan in 1960. These extensive publications provide data for a large number of earthquakes in the western Pacific region. criteria were established to limit the earthquakes considered in this region to a workable number. Japanese earthquakes were considered if they incurred a Japanese (JMA) intensity of 5.0 or greater, with a recorded peak ground acceleration greater than or equal to $0.1 \mathrm{~g}$. Earthquakes in New Zealand, Taiwan, and the Philippines were considered if there was some reported damage to highrise structures. Because of lack of published data, earthquakes in China were not considered.

\subsection{Damage States}

The prediction of dollar losses in high-rise structures damaged by earthquakes requires information about damage sustained by buildings that have been exposed to seismic ground motion. Normally, in the articles that deal with damage to buildings, the failure mechanisms and description of damage are reported, but seldom is the dollar value of loss or the damage ratio explicitly given. Because of this lack of information and also because of the different backgrounds and motives of those who report the damage value in buildings after 
an earthquake, it was considered necessary to use a simple measure of damage. Given the statistical nature of the studies, reported damage to buildings was classified according to discrete damage states.

A nonlinear scale based on previous experience was employed (Whitman, 1973). Table 3.2 shows the state, the description of damage, the central value, and the intervals covered. A graphic representation of this scale is shown in Figure 3.9.

\subsection{Data Base Management}

The large volume of data collected during the course of this project necessitated the use of a data-base-management system to handle the information. We chose a general-purpose data-management system (MRI SYSTEM 2000), available at the Lawrence Berkeley Laboratory. This system allows the user to define data elements and repeating groups at many different levels and to specify the hierarchical relationship of each element to the others. The data base may be readily updated and manipulated to generate statistics and summary tables or to prepare reports.

The flexibility of the MRI SYSTEM 2000 increases user efficiency and facilitates cross correlation between the many motion and damage parameters stored in the data base. The information contained in the data base can thus be applied to motion-damage relationships, seismological theories, and seismicity forecasts. As more data are obtained, the data base can be augmented and expanded as needed.

3.5.1 Data Base HIRISE: Organization and Structure. Data Base HIRISE consists of three levels. At the top of the hierarchy is a city, or more appropriately, an urban area. At the second level are three independent repeating groups describing each earthquake, each ground station or building site, and each element in the grid system used to discretize the area. additional level is used to describe the effects of each earthquake at a specific site or grid location. The basic structure of the data base is shown schematically in Figure 3.10.

Most motion and damage information appears in reports that describe the effects of one particular earthquake; we have organized this information 
according to the urban areas affected. The data base is thus able to indicate the seismicity of each area; to show readily the effects of cumulative damage to buildings; and to provide a historical survey of design requirements, construction practices, and structural systems, as well as the character of earthquake damage, in a given area. At present, the data base, which includes selected earthquakes from 1906 to 1979, documents damage to high-rise buildings in 26 urban centers of 12 countries. Each metropolis appears in the data base as a separate entry with the structure shown in Figure 3.10.

The most significant and reliable information on the data collection forms was selected for input to the data base. A pattern emerged indicating those parameters that were both widely reported and statistically significant for correlation studies. Some unreported items could be reasonably estimated and were added to the data base; other items were unavailable or too difficult to obtain.

The HIRISE data-base definition, shown in Figure 3.11, includes 118 elements used for storing data values. Six types of data may be stored: NAME, TEXT, INTEGER, DECIMAL, DATA, and MONEY. Where there are multiple occurrences of data values, repeating groups are used. To save memory, a NON-KEY option is available for elements that do not require frequent retrieval. Elements to be used as access criteria for retrieval are defined as KEY elements. For example, a list of rock sites can be readily generated because SITE GEOLOGY is a KEY element. A "padding" option leaves space in the data file directories for future additions. (Further details are presented in Control Data Corporation, 1976.)

The data-base system is quite versatile and can be used to perform a wide variety of operations. Examples of simple sorting operations include the the following: listing all sites for which we have tripartite response spectra that can be used directly to generate El values; I isting all buildings that suffered greater than 50\% damage; listing the height, number of stories, plan dimensions, design period, and measured period for all steel, moment-resisting frame buildings. Several such sample listings are given in Appendix B. 
3.5.2 Creating the Data Base. Once the structure and elements of the data base were defined, data could be transferred from the data collection forms to the data base. To simplify the coding process, many items were assigned a number or a short two- or three-letter code. For example, a collapsed building is assigned a DAMAGE STATE of 8 , a rock site is specified as RK, and an unreinforced masonry building is denoted by the code UM. The link between the data collection forms and the data-base elements is shown by the codes that appear on the forms in Figures 3.12 through 3.15 . To reflect the hierarchy of elements in HIRISE and to show the sequence of data entry, the forms are reordered as follows: Form 1, Form 3, Form 4, Form 2.

Several elements require explanation. The MAJOR CITY CODE was created in order to avoid repetition of the earthquake data on Form 1 in cases where more than one city or area were affected. One city is designated as the MAJOR city $(C O D E=1)$ and all other areas are MINOR $(\operatorname{CODE}=\emptyset)$. The data on Form 1, including the summary table at the bottom, are then entered only for the major city. To avoid duplication, this information is then referenced under each minor city. If foreshocks or aftershocks have occurred, the damage is generally lumped together and attributed to the primary shock. Thus, related shocks are given a FORE/AFTERSHOCK CODE, and only the information at the top of Form 1 (Section 1.1) is entered. All damage data are included in the summary of effects for the major city and primary shock.

After HIRISE was established and the data entered, a number of lists, summaries, and tables were generated to check the data and insure their accuracy.

\subsection{Summary of Data Collected}

Table 3.3 summarizes the data collected. Included in the table are comments regarding additional data that will be sought. Augmenting the empirical data base will be a continuing effort throughout the project.

Appendix B gives examples of more detailed lists of the information collected. These lists are provided to show the extent of the data collected as well as the versatility of the data-base-management system. 
$79 / 04 / 01$

\section{CO*}

* GREECE

* GREECE

* guatemala

* italy

* japar

* Japan

* JaPAN

* japan

* JaPan

- JaPAN

* JaPan

- MEXICO

- MEXICO

- MEXICO

- MEXICO

- MEXICO

- MEXICO

- MEXICO

- MEXICO

- MEXICO

- MEXICO

- MEXICO

- MEXICO

- MEXICO

- MEXICO

- MEXICO

* MEXICO

- MEXICO

- morocco

* nicarajua

* nicarajua

* nicarajua

- nicarajua

* nicarajua

- nicarajua

* nicarajua

- nicarajua

- nicarajua

* philippines

- philipoines

- romania

* uniteo states

- united states
UREAN AREA

SALONICA

SALONICA

GUATEMALA

FRUILI

HACHINOHE

HACHINOHE

HACHINOHE

IZU PENINSULA

NIIGATA

SENDAI

TOKYO

MEXICO

MEXICO

MEXICO

MEXICO

MEXICO

MEXICO

MEXICO

MEXICO

MEXICO

MEXICO

MEXICO

MEXICO

MEXICO

MEXICO

MEXICO

MEXICO

MEXICO

AGADIR

MANAGUA

MANAGUA

MANAGUA

MANAGUA

MANAGUA

MANAGUA

MANAGUA

MANAGUA

MANAGUA

COTABATO

COTABATO

BUCHAREST

ANCHORAGE

ANCHORAGE
EARTHQUAKE IO

GRE - O6-78-F1

GRE $-06-78$

GUA $-02-76$

IT $A-05-7 E$

$J P N-05-6 \varepsilon$

$J P N-05-68-A 1$

$J P N-06-78$

$J P N=05-74$

$J P N=06-64$

$J P N=06-78$

$J P N=09-23$

$M E X-06-11$

$M E X-12-37$

$M E X-02-43$

$M E X-04-44$

MEX-01-51

MEX-07-57

$M E X-07-57-41$

MEX-0 8-59

MEX-12-61

MEX $-05-52$

MEX-05-62-A1

MEX $-07-64$

$M E X-12-65$

MEX-08-68

MEX-08-73

MEX-11-78

MEX-14-79

$M O R-02-60$

$M N G-01-68$

$M N G-01-68-A_{1}$

$M N G-01-68-A 2$

$M N G=01-72$

$M N G-01-72-A_{1}$

$M N G-01-72-A 2$

$M N G-12-72-A 1$

$M N G-12-72-A 2$

MNG-12-72

PHL $-08-76$

PHL $-08-76-A 1$

ROM-03-77

ALA-10-54

ALA-0 3-64
7.50

6.25

6.50

5.25

6.70

6.50

6.80

6.50

7.00

7.00

7.50

5.75

4.50

5.00

5.20

5.60

7.90

6.80

7.20

6.75

8.40

\section{DATE}

$05 / 24 / 1978$

$06 / 20 / 1978$

$02 / 04 / 1976$

$05 / 06 / 1976$

$05 / 16 / 1968$

$05 / 16 / 1968$

$06 / 12 / 1978$

$05 / 08 / 1974$

$06 / 06 / 1964$

$06 / 12 / 1978$

$09 / 01 / 1923$

$06 / 07 / 1911$

$12 / 23 / 1937$

$02 / 22 / 1943$

$04 / 15 / 1944$

$01 / 05 / 1951$

$07 / 28 / 1957$

$08 / 04 / 1357$

$08 / 26 / 1959$

$12 / 10 / 1961$

$05 / 11 / 1962$

$05 / 19 / 1962$

$07 / 06 / 1964$

$12 / 09 / 1964$

$08 / 02 / 1968$

$08 / 28 / 1973$

$11 / 29 / 1978$

$03 / 14 / 1970$

$02 / 29 / 1960$

$01 / 04 / 1968$

$01 / 18 / 1968$

$01 / 22 / 1968$

$01 / 02 / 1972$

$01 / 04 / 1972$

$01 / 05 / 1972$

$12 / 23 / 1972$

$12 / 23 / 1972$

$12 / 23 / 1972$

$08 / 16 / 1976$

$08 / 17 / 1976$

$03 / 04 / 1977$

$10 / 03 / 1954$

$03 / 28 / 1964$ 


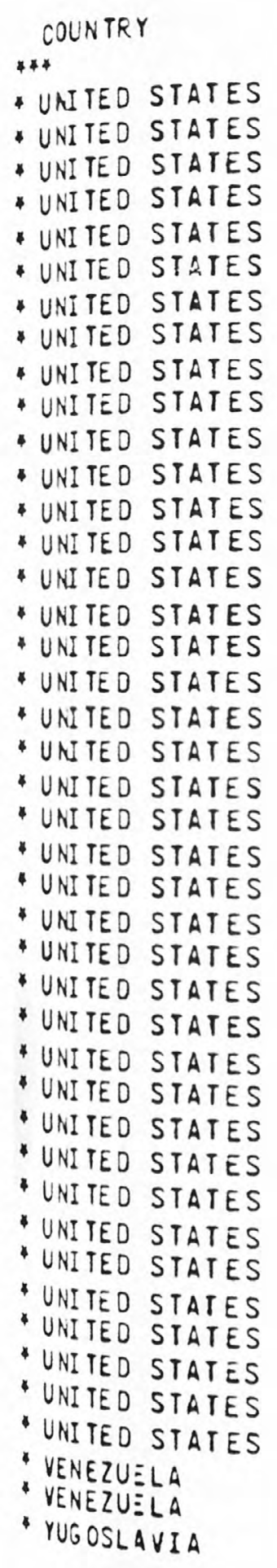

UREAN AREA
BAKERSFIELD
EAKERSFIELD
BAKERSFIELO
LOS ANGELES
LOS ANGELES
LOS ANGELES
LOS ANGELES
LOS ANGELES
LOS ANGELES
LOS ANGELES
LOS ANGELES
OAKLAND
OAKLAND
OAKLAND
OAKLAND
OAKLAND
OLYMPIA
OLYMPIA
SAN FRANCISCO
SAN FRANCISCO
SAN FRANCISCO
SAN FRANCISCO
SAN FRANCISCO
SAN JOSE
SAN JOSE
SAN JOSE
SAN JOSE
SANTA BAREARA
SANT A BAREARA
SANTA BAREARA
SANT BAREARA
SANTA BAREARA
SANTA BAREARA
SANTA BARBARA
SANTA BAREARA
SEATTLE
SEATTLE
TACOMA
TACOMA
HHITTIER
CARABELLEDA
CARACAS
SKOPJE

EARTHQUAKE ID

$K R N-07-52$

$K R N-08-52$

$S F D-02-71$

$\mathrm{LBH}-03-33$

$T O R-11-41$

$K R N-07-52$

$K R N-08-52$

$B O R-04-68$

$L Y T-09-70$

SFD-02-71

$P M G-02-73$

SFR-04-06

$J O S-09-55$

$O A K-10-5 E$

$S F R-03-57$

ROS-10-69

OL Y $-04-49$

SEA-O4-65

SFR $-04-0 E$

JOS-09-55

$O A K-10-55$

$S F R-03-57$

ROS $-10-69$

SFR-04-06

JOS $-09-55$

$O A K-10-55$

$S F R-03-57$

$S B A-06-25$

$S B A-06-41$

$K R N-07-52$

$K R N-08-52$

$B O R=04-68$

$S F D-02-71$

$P M G-02-73$

$S B A-08-78$

OL $Y-04-4$ C

SEA $-04-65$

$O L Y=04-4 \mathrm{~S}$

SEA $-04-65$

ALA $-03-64$

VNZ-07-67

$V N Z-07-67$

$Y \cup G-07-63$
M DATE

$\begin{array}{ll}5.80 & 07 / 21 / 1952 \\ & 08 / 22 / 1952 \\ & 02 / 09 / 1971\end{array}$

$6.30 \quad 03 / 11 / 1533$

$5.40 \quad 11 / 14 / 1941$

$7.70 \quad 07 / 21 / 1952$ $08 / 22 / 1952$

$6.40 \quad 04 / 09 / 1968$

$5.40 \quad 09 / 12 / 1970$

E.40 02/03/1971

$5.90 \quad 02 / 21 / 1973$

$04 / 18 / 1 \subseteq 0 E$

$09 / 05 / 1955$

$5.50 \quad 10 / 24 / 1955$

$03 / 22 / 1957$

$10 / 02 / 1960$

$7.10 \quad 04 / 13 / 1549$

$04 / 29 / 1965$

$8.2504 / 18 / 1906$

$09 / 05 / 1955$

$10 / 24 / 1955$

$5.30 \quad 03 / 22 / 1957$

$5.70 \quad 10 / 02 / 1969$

$04 / 18 / 1906$

$5.80 \quad 09 / 05 / 1955$

$10 / 24 / 1955$

$03 / 22 / 1957$

$6.30 \quad 06 / 29 / 1925$

$5.90 \quad 07 / 01 / 1941$

$07 / 21 / 1952$

$05 / 22 / 1952$

$04 / 09 / 1968$

$02 / 09 / 1971$

$02 / 21 / 1973$

$5.1008 / 13 / 1978$

$04 / 13 / 1 \subseteq 49$

$6.50 \quad 04 / 29 / 1965$

$04 / 13 / 1949$

$04 / 29 / 1965$

$03 / 28 / 1964$

$07 / 29 / 1967$

$6.50 \quad 07 / 29 / 1967$

$6.00 \quad 07 / 26 / 1963$ 


\begin{tabular}{|c|c|c|c|c|}
\hline \multirow{2}{*}{$\begin{array}{l}\text { Damage } \\
\text { State }\end{array}$} & \multirow{2}{*}{ Level of Damage } & \multicolumn{3}{|c|}{$\begin{array}{c}\text { Damage Ratio* } \\
(\%)\end{array}$} \\
\hline & & Central Value & & Range \\
\hline 0 & No damage & 0.03 & & -0.05 \\
\hline 1 & Negligible damage & 0.08 & 0.05 & -0.14 \\
\hline 2 & $\begin{array}{l}\text { Minor nonstructural damage - a few } \\
\text { walls and partitions cracked, inci- } \\
\text { dental mechanical and electrical } \\
\text { damage }\end{array}$ & 0.24 & 0.14 & $t-0.40$ \\
\hline 3 & $\begin{array}{l}\text { Substantial nonstructural damage -- } \\
\text { more extensive cracking (but still } \\
\text { not widespread); possibly damage to } \\
\text { elevators and other mechanical/ } \\
\text { electrical components }\end{array}$ & 0.67 & 0.40 & -1.1 \\
\hline 4 & $\begin{array}{l}\text { Major nonstructural damage (wide- } \\
\text { spread) -- possibly a few beams and } \\
\text { columns cracked, although not } \\
\text { noticeable }\end{array}$ & 2 & 1.1 & -3.2 \\
\hline 5 & $\begin{array}{l}\text { Minor structural damage -- obvious } \\
\text { cracking or yielding in a few struc- } \\
\text { tural members; substantial nonstruc- } \\
\text { tural damage with widespread cracking }\end{array}$ & 5 & 3.2 & -9 \\
\hline 6 & $\begin{array}{l}\text { Substantial structural damage requir- } \\
\text { ing repair or replacement of some } \\
\text { structural members; associated exten- } \\
\text { sive nonstructural damage }\end{array}$ & 15 & & -25 \\
\hline 7 & $\begin{array}{l}\text { Major structural damage requiring } \\
\text { repair or replacement of many struc- } \\
\text { tural members; associated nonstruc- } \\
\text { tural damage requiring repairs to } \\
\text { major portion of interior }\end{array}$ & 45 & & -70 \\
\hline 8 & Collapse or condemnation & 100 & & - \\
\hline
\end{tabular}

Source: Whitman (1973)

*Ratio of cost of loss to replacement cost (called Damage Factor in this report) 
TABLE 3.3

SUMMARY OF DATA COLLECTED

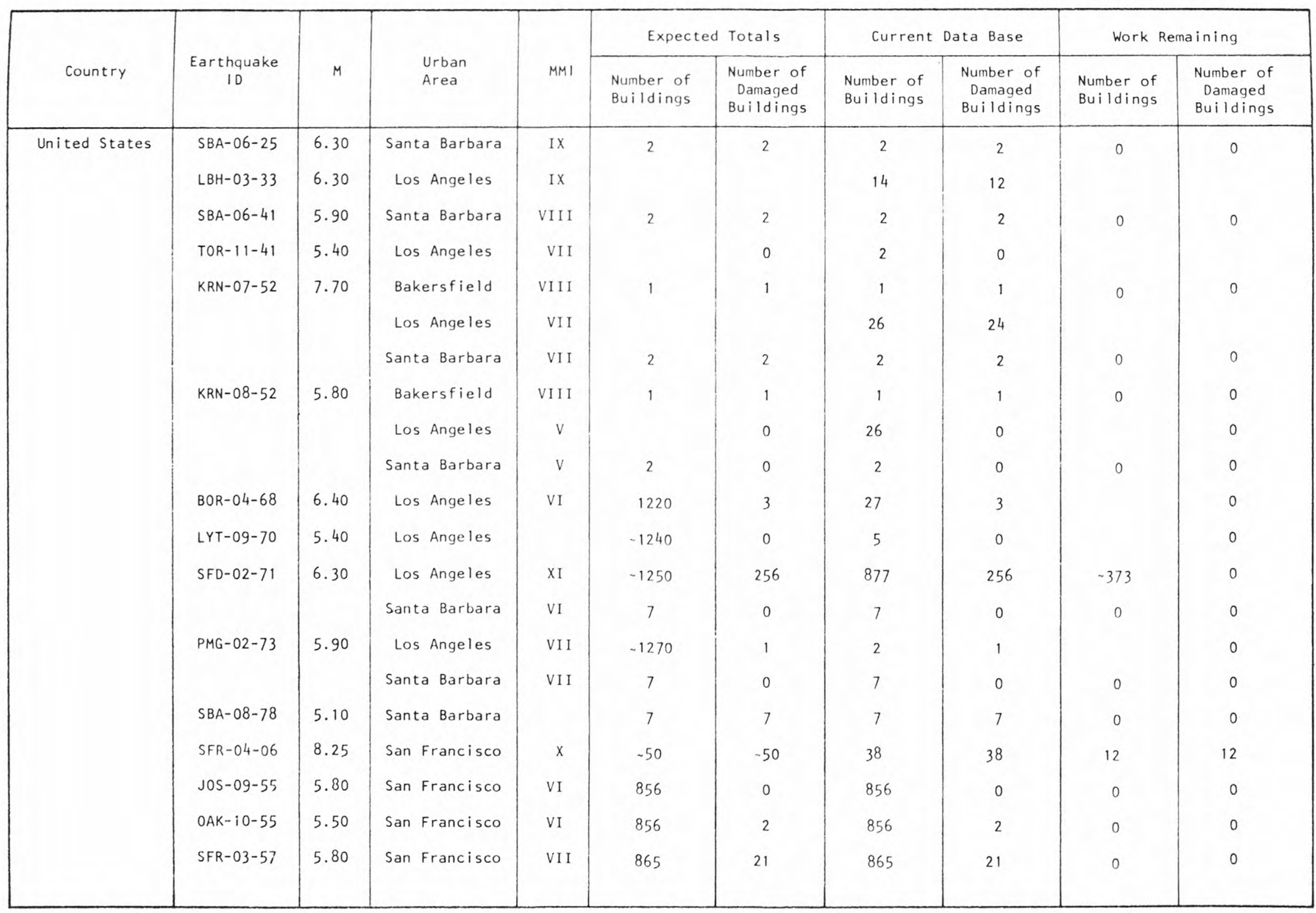


TABLE 3.3 (Continued)

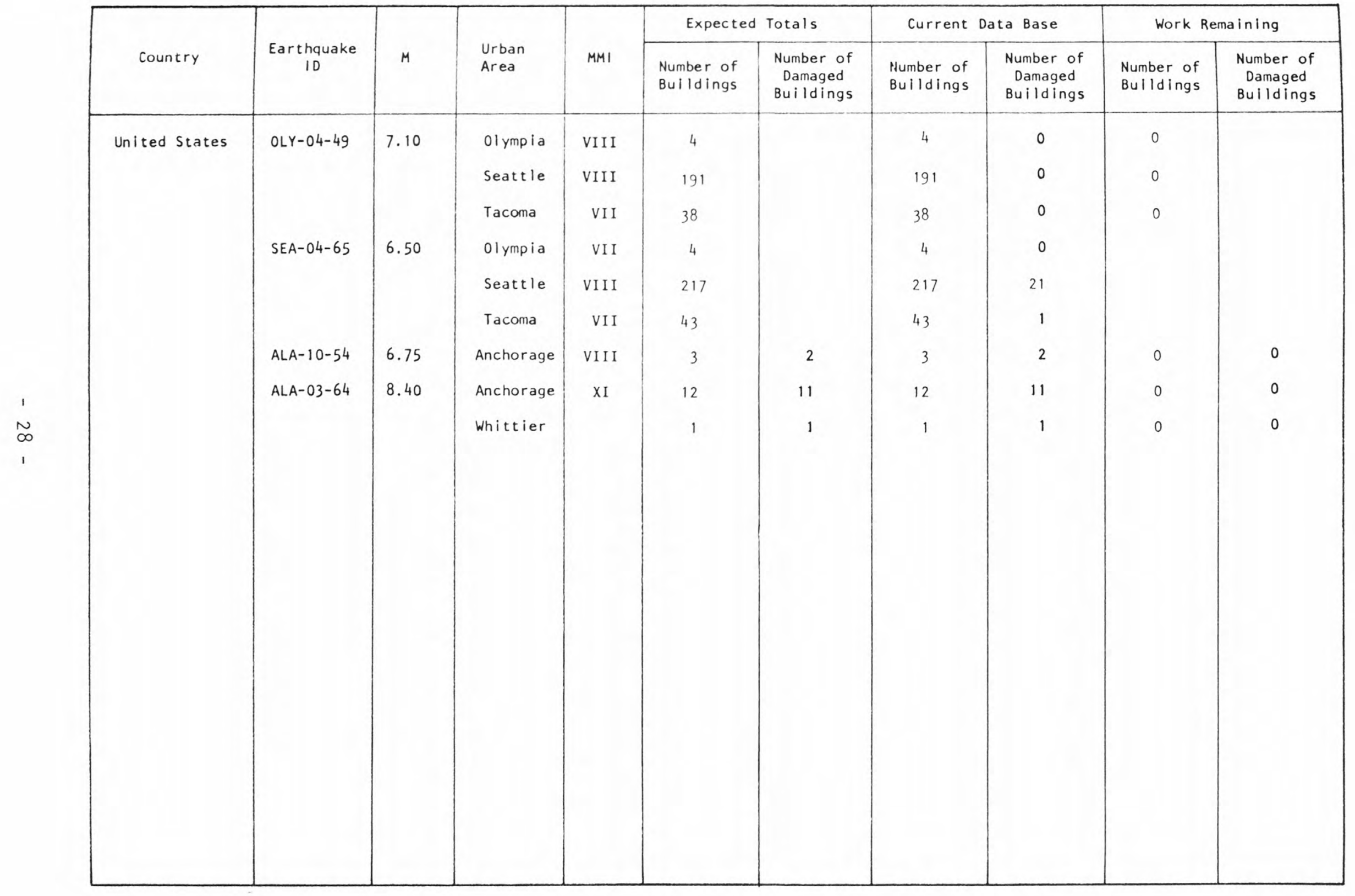


TABLE 3.3 (Continued)

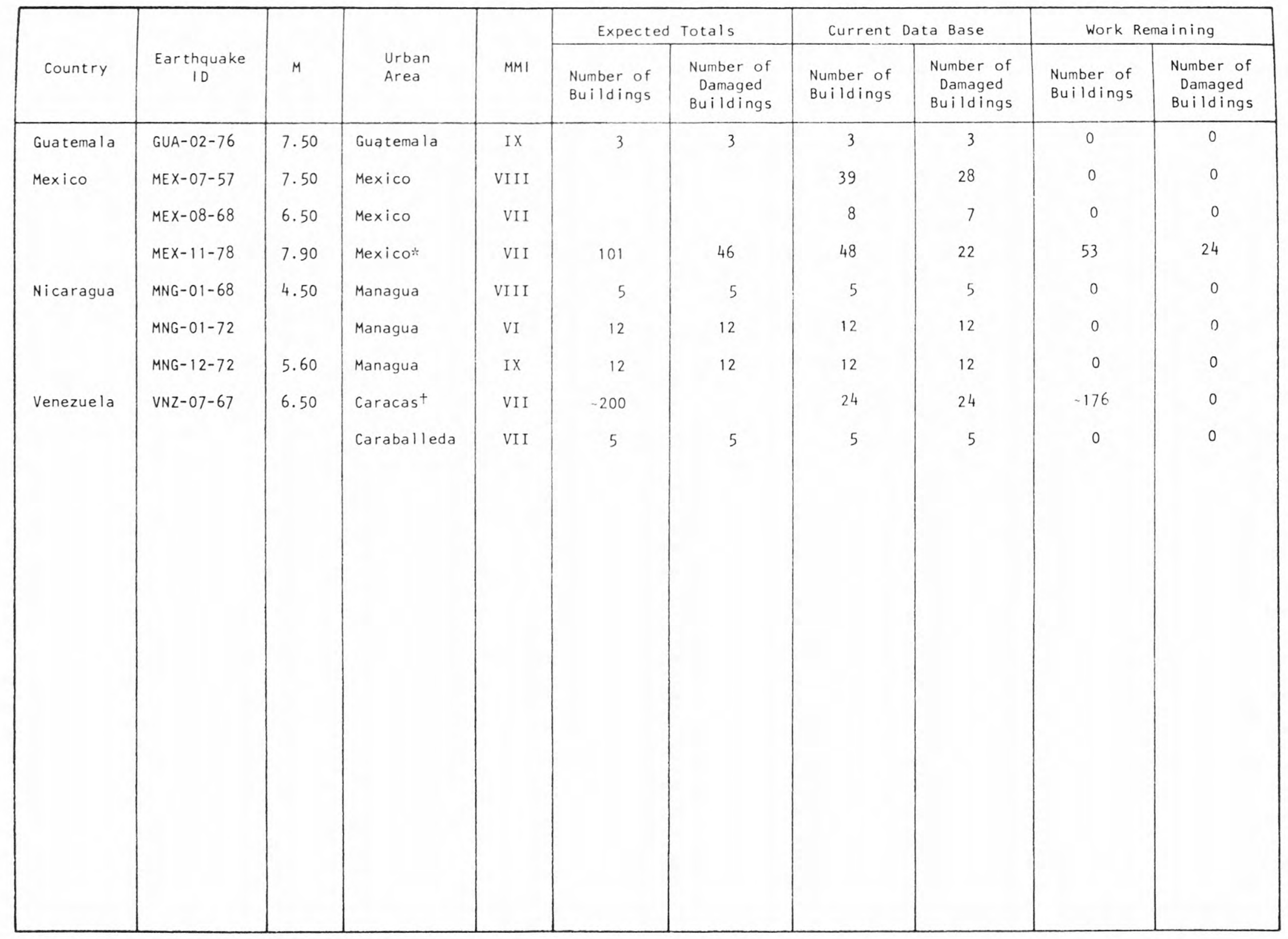

*4 zones only (Appendix A, Reference MEX 13)

tPalos Grandes area only (Appendix A, Reference VNZ 6) 
TABLE 3.3 (Cont inued)

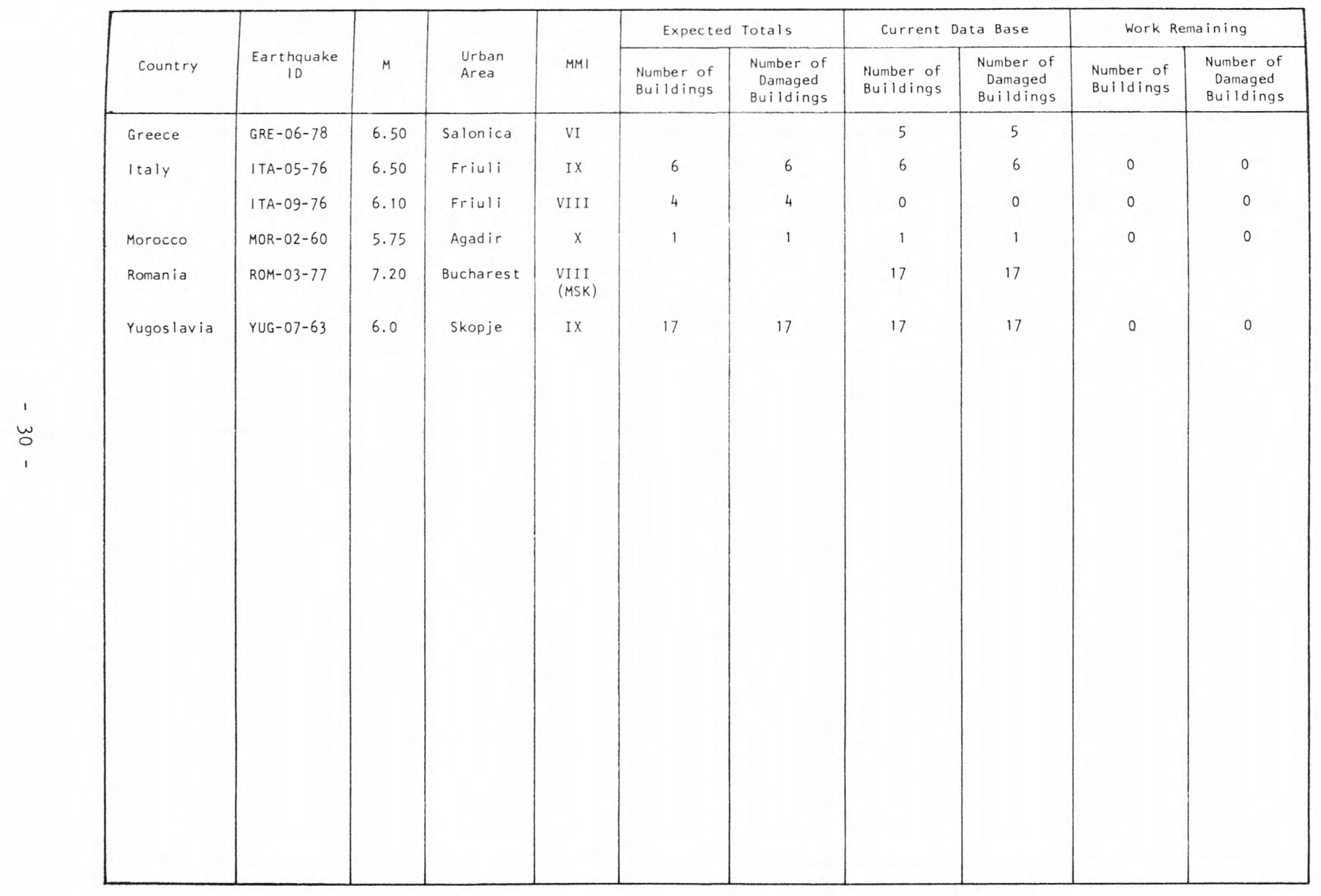


TABLE 3.3 (Continued)

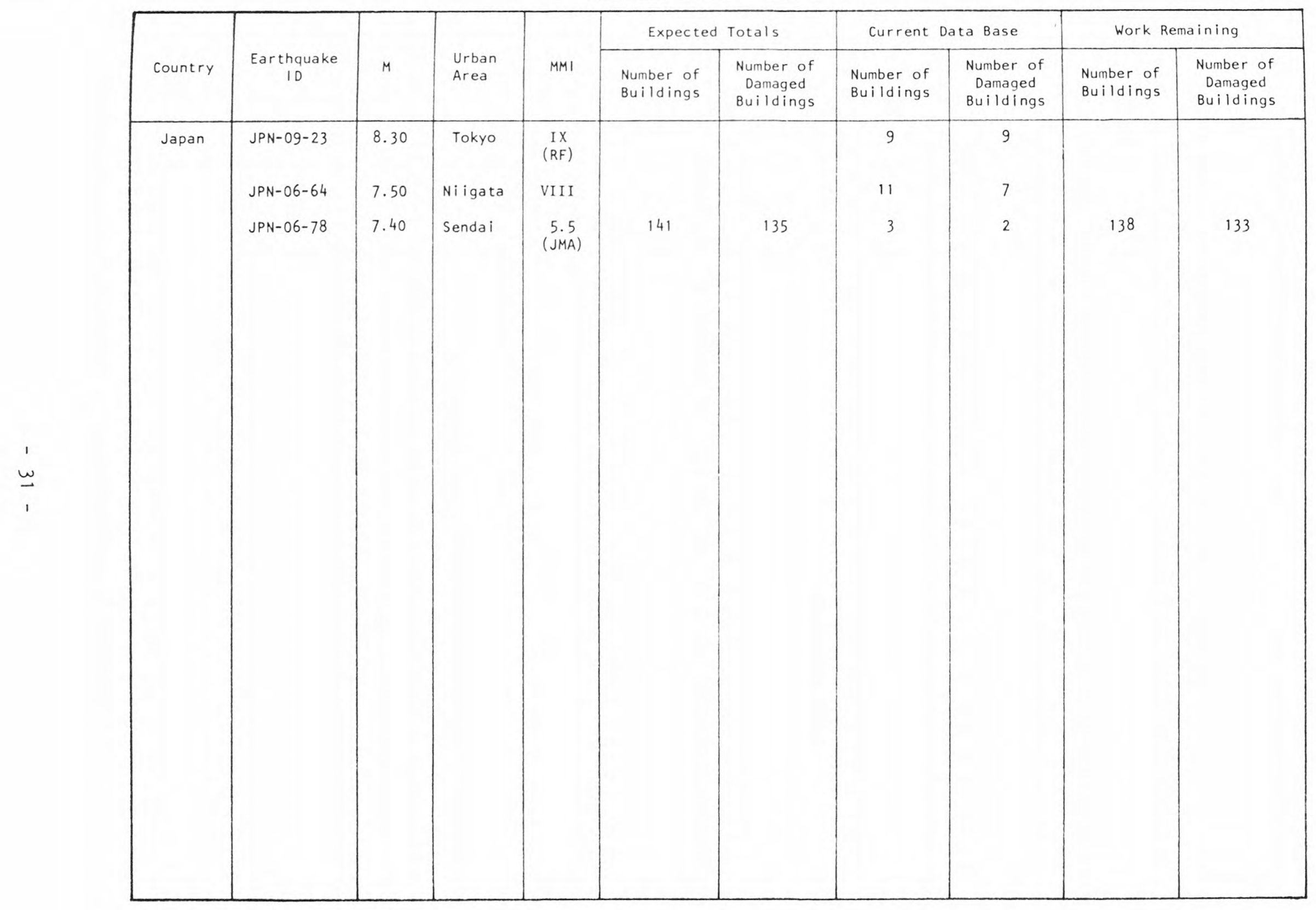




\subsection{EARTHQUAKE}

1.1.1 Earthquake Name:

1.1.2 Date:

1.1.3 Origin Time: Local

1.1. 4 Latitude: GMT

1.1.5 Depth $(\mathrm{km})$ :

1.1.6 Magnitude: $\mathrm{M}_{\mathrm{L}} \longrightarrow \mathrm{M}_{\mathrm{S}} \longrightarrow \mathrm{M}_{\mathrm{b}}$

1.1.7 Type of Faulting:

1.1.8 Length of Surface Faulting $(\mathrm{km})$ :

1.1.9 ID of Significant Aftershocks (see separate form for each):

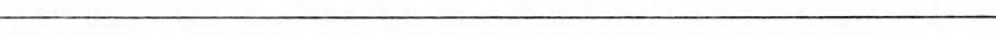

\subsection{EFFECTS}

1.2.1 Estimated Total Damage (U.S. \$ for Year of Earthquake):

1.2.2 Number of Deaths: Injuries:

1.2.3 Maximum Intensity: MMI RFI

\section{Other (specify)}

1.2.4 Land Area $\left(\mathrm{km}^{2}\right)$ : For MMI $\geq 4$ $M M I \geq 6$

1.2.5 Population in MMI $\geq 6$ Zone:

1.2.6 Number of Ground Motion Stations with Records:

1.2.7 Principal Communities Involved: $\square$ City Maps $\square$ Aerial Photos

\begin{tabular}{|c|c|c|c|c|c|}
\hline $\begin{array}{l}\text { Name of Town, } \\
\text { City, or } \\
\text { Urban Area }\end{array}$ & $\begin{array}{l}\text { Number of } \\
\text { High-Rise } \\
\text { Buildings } \\
\text { Affected } \\
\text { MMI } \geq 4\end{array}$ & $\begin{array}{l}\text { Number of } \\
\text { High-Rise } \\
\text { Buildings } \\
\text { Damaged }\end{array}$ & $\begin{array}{l}\text { Number of } \\
\text { High-Rise } \\
\text { Buildings } \\
\text { w/Recorded } \\
\text { Response }\end{array}$ & $\begin{array}{l}\text { Maximum } \\
\text { Intensity } \\
\text { (see } \\
1.2 .3 \text { ) }\end{array}$ & $\begin{array}{l}\text { Peak } \\
\text { Ground } \\
\text { Accel. } \\
\text { (g) }\end{array}$ \\
\hline & & & & & \\
\hline & & & & & \\
\hline All other & & & & & \\
\hline Total & & & & & \\
\hline
\end{tabular}

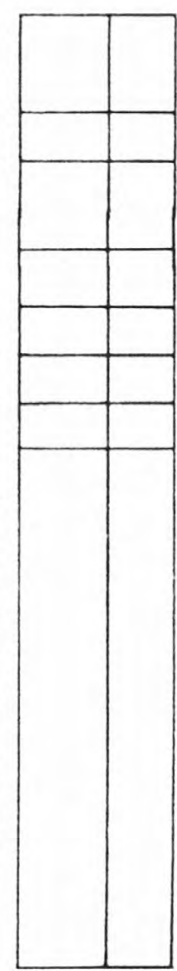

FIGURE 3.1 GENERAL EARTHQUAKE DATA (FORM 1) 
Site ID:

By:

Date:

Earthquake ID:

FORM 2: MOTION AND DAMAGE DATA

2.1 MOTION AT SITE

2.1.1 Distance from Site to $(\mathrm{km})$ :

Epicenter Hypocenter

2.1.2 Site Intensity: MMI FRI Rupture

2.1.3 Peak Acceleration at Site (g): Estimated Other (specify)

\begin{tabular}{|c|c|c|c|c|}
\hline \multicolumn{2}{|c|}{$\begin{array}{c}\text { Recording } \\
\text { Instruments }\end{array}$} & Component & Component & $\begin{array}{l}\text { Vertical } \\
\text { Component }\end{array}$ \\
\hline Type & Location & & & \\
\hline & & & & \\
\hline & & & & \\
\hline
\end{tabular}

2.1.4 Duration of Motion Reported:

Estimated: $\square 15 \mathrm{sec} \square 30 \mathrm{sec} \square 60 \mathrm{sec} \square 120 \mathrm{sec}$

2.1.5 Available Data:

Response Spectrum: $\square$ 5\% Damping, Tripartite $\square$ other

Time History: $\square$ Digitized $\square$ corrected $\square$ other

2.1.6 ID of Nearest Recording Stations:

2.1.7 Maximum Interstory Displacement (cm):

2.2 PRIMARY DAMAGE

2.2.1 Primary Cause of Damage: $\square$ Foundation Soil Failure $\square$ shaking $\square$ settlement $\square$ slope Failure

2.2.2 Replacement Cost ( $\$ /$ Year):

2.2.3 Damage Repair Cost ( $\$ /$ Year):

2.2. Structural $\%$ Architectural $\%$ Mech. E Elec.

2.2.4 Damage Factor (\%):

2.2.5 Damage State: $\square$ No Damage

$\square$ Negligible

$\square$ Minor Nonstructural

$\square$ Substantial Nonstructural

$\square$ Major Nonstructural

2. 3 SECONDARY DAMAGE

2.3.1 Number of Deaths:

2.3.2 Loss of Building Function ( $\$ /$ Year): Cause: $\square$ structural $\square$ Architectural $\square$ Mech. E Elec.

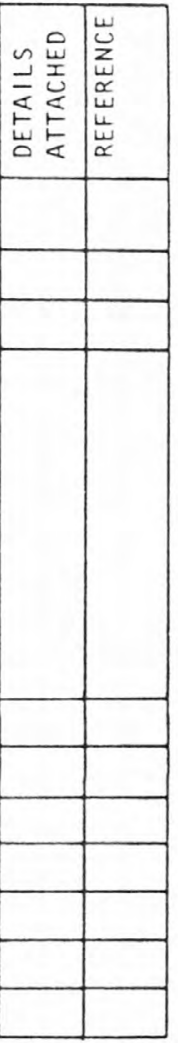


3.1 GENERAL SITE INFORMATION

3.1.1 Instrumentation at Site:

Ground Station: $\square$ Free Field $\square$ Basement of Lowrise Building High-rise Building: $\square$ Basement $\square$ Upper Story $\square$ None

3.1.2 Latitude: Long i tude:

3.1 .3 Address:

3.2 SITE GEOLOGY

3.2.1 Site Category:

$\square$ Rock $\square<10$ m Alluvium Underlain by Rock

$\square$ Alluvium $\square$ 10-60 m of Alluvium Underlain by Rock

3.2.2 Average Specific Gravity:

3.2.3 Average Shear Wave Velocity: $\mathrm{m} / \mathrm{s}$, $\mathrm{ft} / \mathrm{sec}$

3.2.4 Depth of Water Table: m

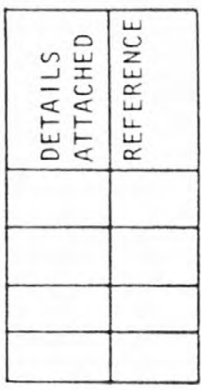

3.3 GENERAL BUILDING INFORMATION

3.3.1 Building Name:

3.3.2 Function/Occupation:

3.3.3 Building Orientation:

3.3.4 Number of Stories (above/below grade):

3.3.5 Height $(\mathrm{m})$ (above/below grade):

3.3.6 Total Floor Area $\left(\mathrm{m}^{2}\right)$ :

3.3.7 Year of Construction:

3.3.8 Construction Cost (U.S. \$):

3.4 BUILDING DESIGN AND CONSTRUCTION

3.4.1 Lateral Force Design Analys is Type: $\square$ None

Static Equivalent: $\square$ Seismic $\square$ wind

Dynamic Analysis: $\square$ Response Spectrum $\square$ Time History

Other:

3.4.2 Lateral Force Design Parameters:

$\begin{array}{ll}\text { L-Axis: } & C_{b}= \\ \text { T-Axis: } & C_{b}=\end{array}$ $\mathrm{S}_{\mathrm{a}}=$ $\mathrm{S}_{\mathrm{a}}=$

3.4.3 Building Period:

\begin{tabular}{|c|c|c|}
\hline L-Axis & Measured & Date \\
\hline T-Axis & & \\
\hline Torsion & & \\
\hline
\end{tabular}
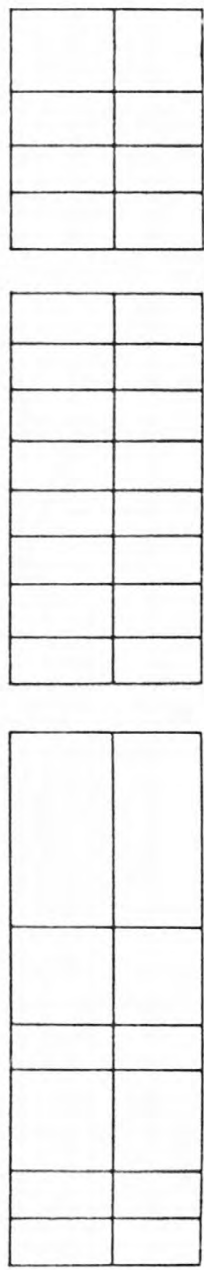

FIGURE 3.3 SITE INFORMATION (FORM 3) 

Date:

\section{FORM 4: BUILDING CATEGORIZATION}

4.1 Foundation:

$\square$ Wall Footing

$\square$ Combine Footing

$\square$ Mat or Raft Foundation

$\square$ Caissons $\square$ Spread Footing

$\square$ Strap Footing

$\square$ Pile Foundation

$\square$ other

$\square$ Bearing Wall

$\square$ other

(L) Directions):

$\square$ Shear Wall

$\square \square$ Braced Frame

$\square \square$ Tube

4.3 Lateral Load-Resisting System

$\square \square$ Moment-Resisting Frame

$\square$ Shear Core

$\square$ Truss Frame

$\square$ other

4.4 Floor System (describe):

4. 5 Structural Material:

$\square$ Steel

Reinforced Concrete

$\square$ Prestressed Concrete

$\square$ Unreinforced Masonry

$\square$ Reinforced Masonry

$\square$ other

4.6 Architectural Material ( $\square \square$ Exterior/Interior):
$\square$ Concrete
$\square$ Concrete Block
$\square$ Hollow Clay Tile
$\square$ Lath and Plaster
$\square \square$ Drywall on Metal Studs
$\square \square$ Glass
$\square$ Drywall on Wood Studs
$\square \square$ Metal
$\square \square$ other

4.7 Configuration: $\square$ Regular $\square$ Irregular

(Discuss):

FIGURE 3.4 BUILDING CATEGORIZATION (FORM 4) 
Site ID:

Earthquake 1D:
By: Date:

FORM 5: DETAILED SITE AND BUILDING INFORMATION

5.0 REMARKS (Specify Item Number of Discussion and Reference Number in Front of Each Discussion):

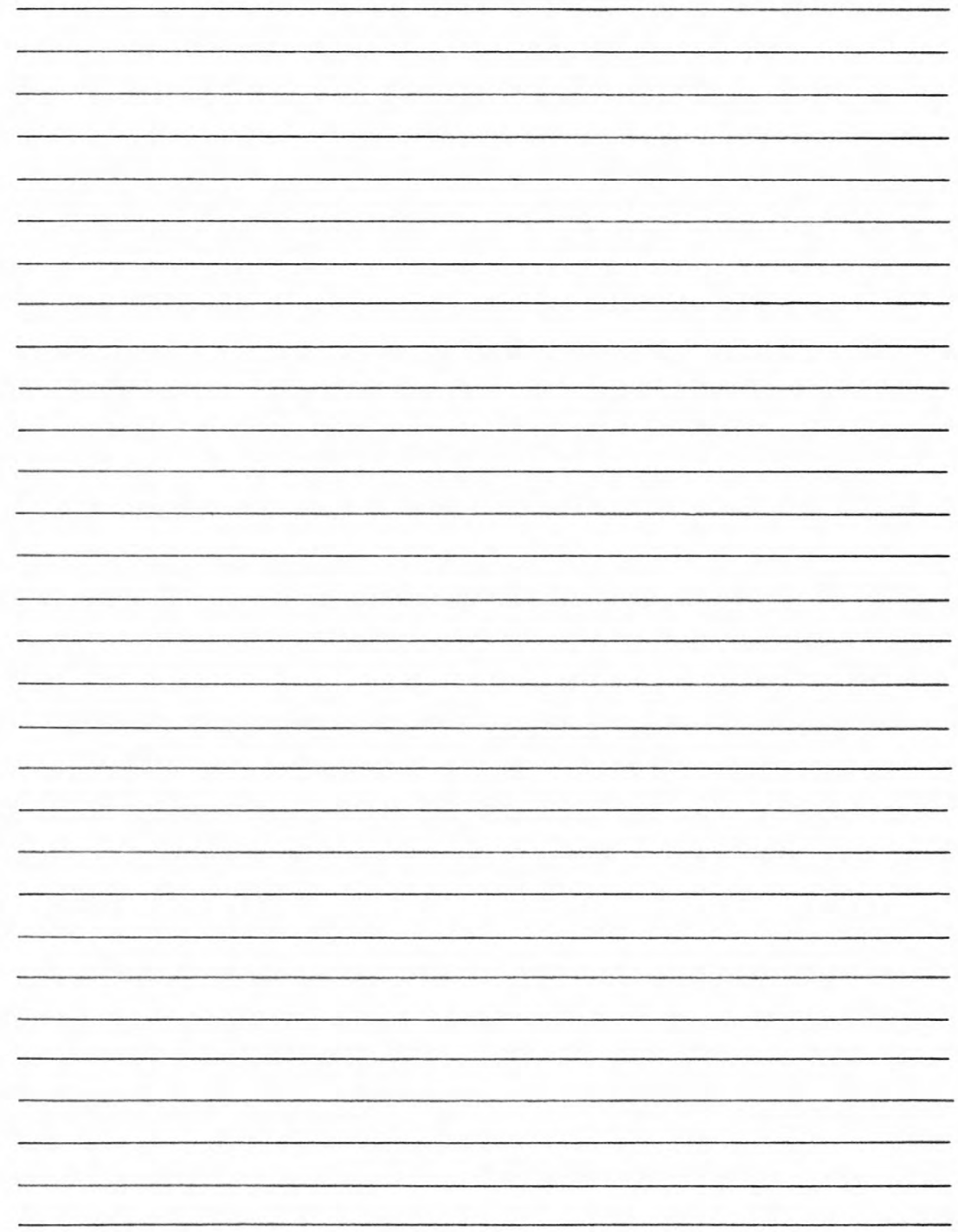

FIGURE 3.5 DETAILED SITE AND BUILDING INFORMATION (FORM 5) 
Earthquake ID:

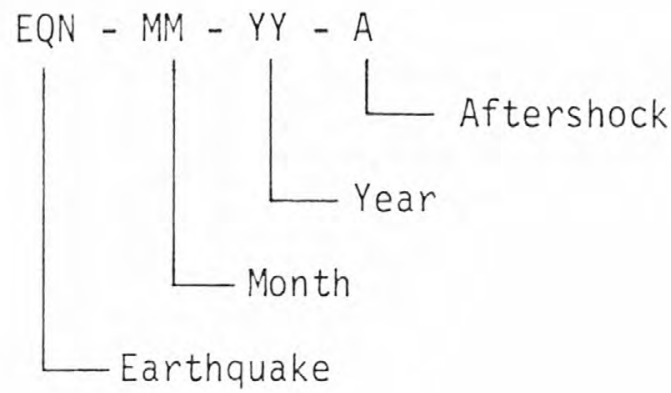

Examples:

$K R N-07-52, K R N-07-52-A$

L Kern County, Ju1y 21, 1952, and Aftershock.

Site ID:

$U S A-S B A-G 001$

$L_{\text {City }}^{L \text { Ground Station or Building ID }}$

G001 - G220: Ground Station Only

B201 - B500: Building with Instrumentation

B501 - B999: Building without Instrumentation

Example:

NIC - HNG - B501

L Nicaragua, Managua, Uninstrumented Building

FIGURE 3.6 EARTHQUAKE AND SITE IDENTIFICATION 


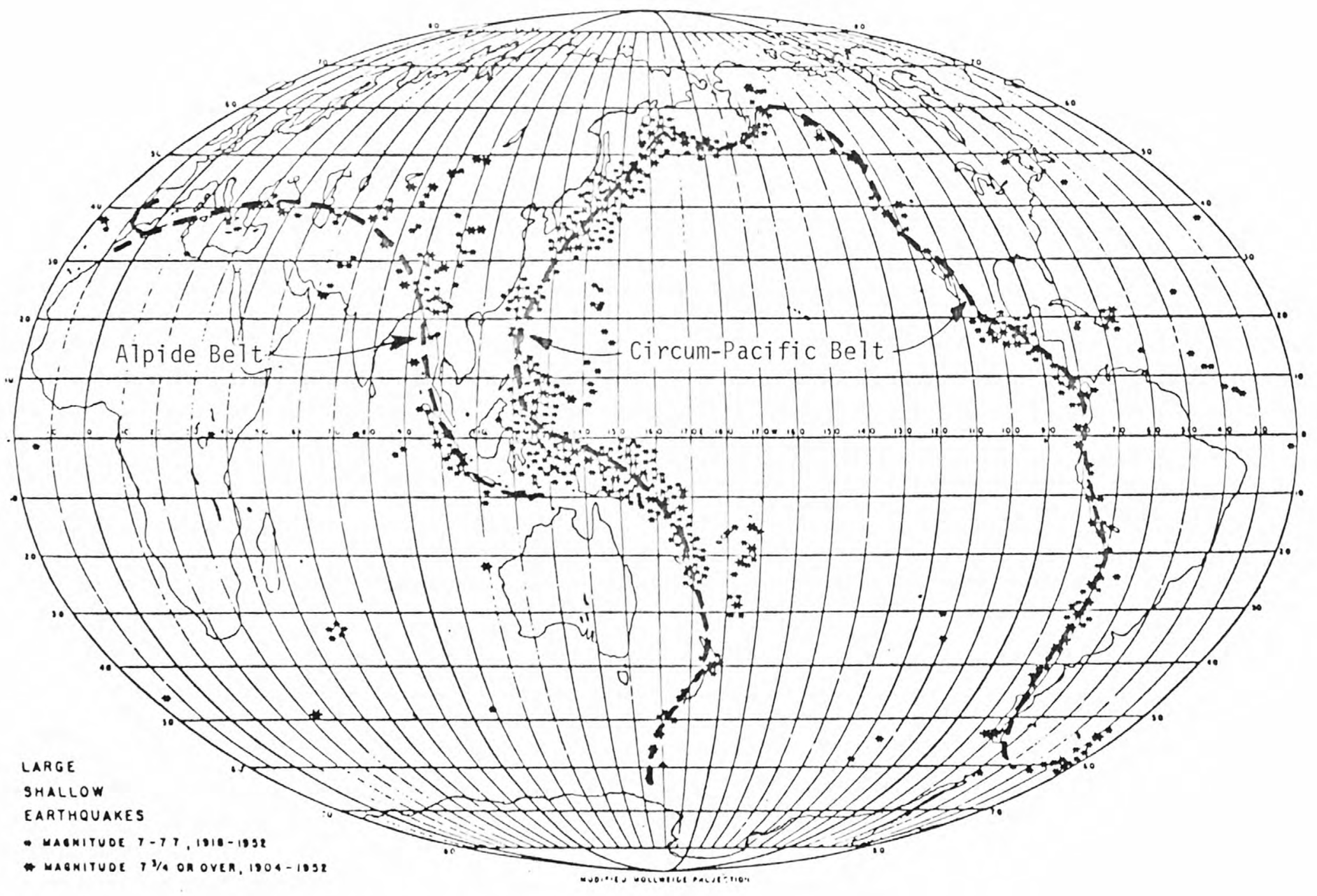

FIGURE 3.7 PRINCIPAL EARTHQUAKE BELTS OF THE WORLD (Adapted from Gutenberg and Richter, 1965) 


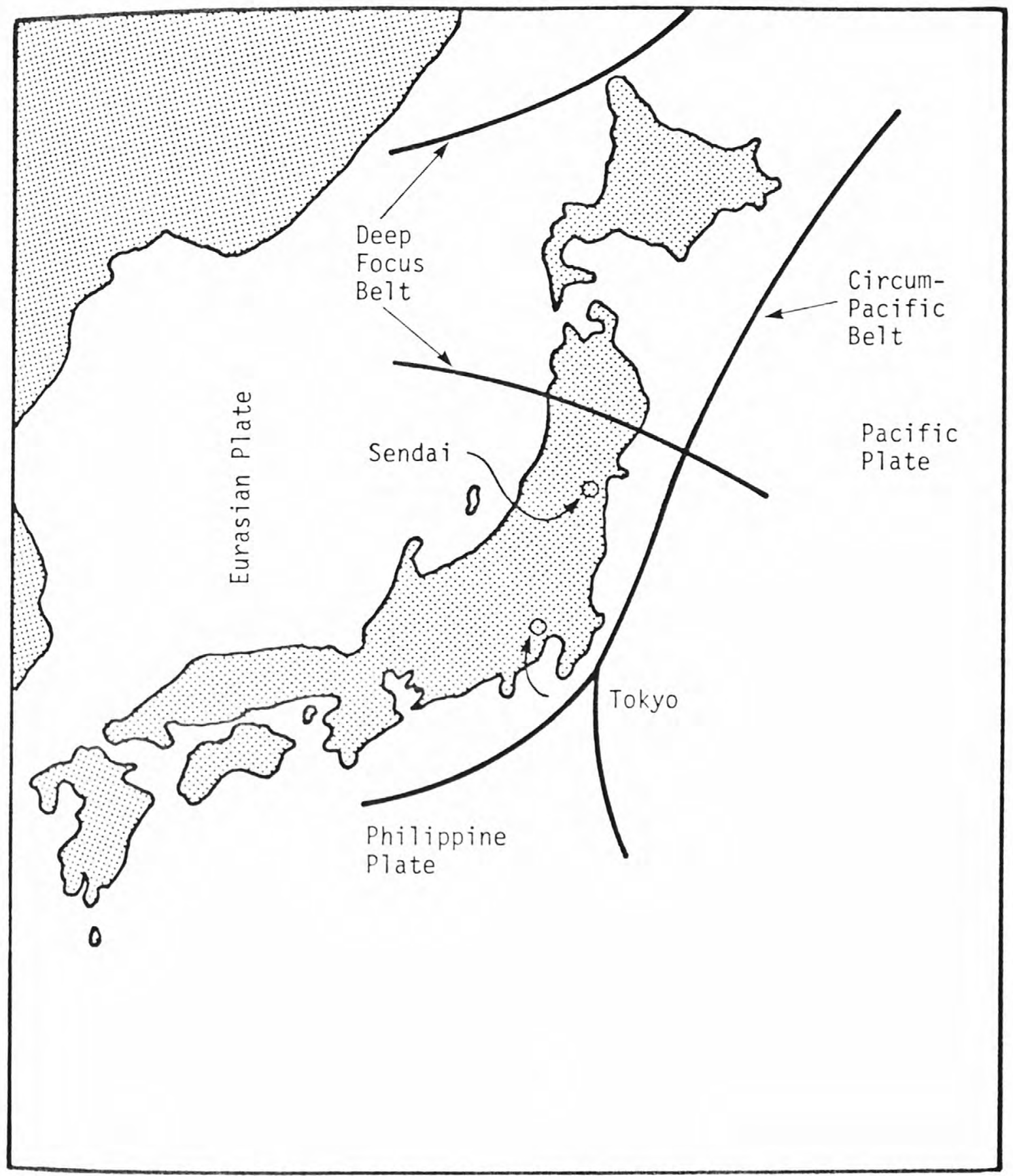

FIGURE 3.8 SEISMIC/GEOLOGIC STRUCTURE OF THE JAPANESE REGION 


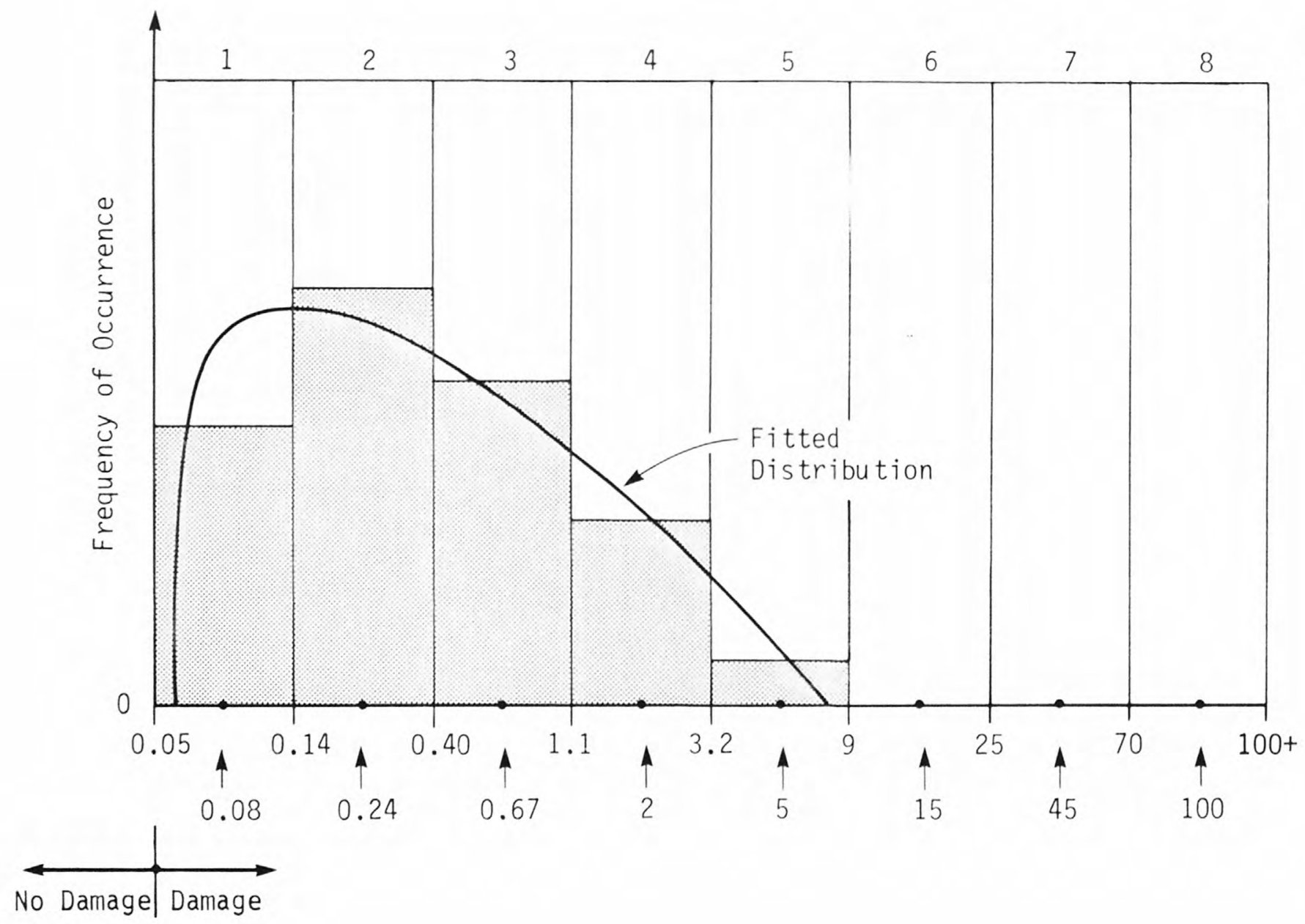

Limits of

Damage Factor (\%)

Central values of Damage Factor (\%)

FIGURE 3.9 SAMPLE DAMAGE-STATE HISTOGRAM 


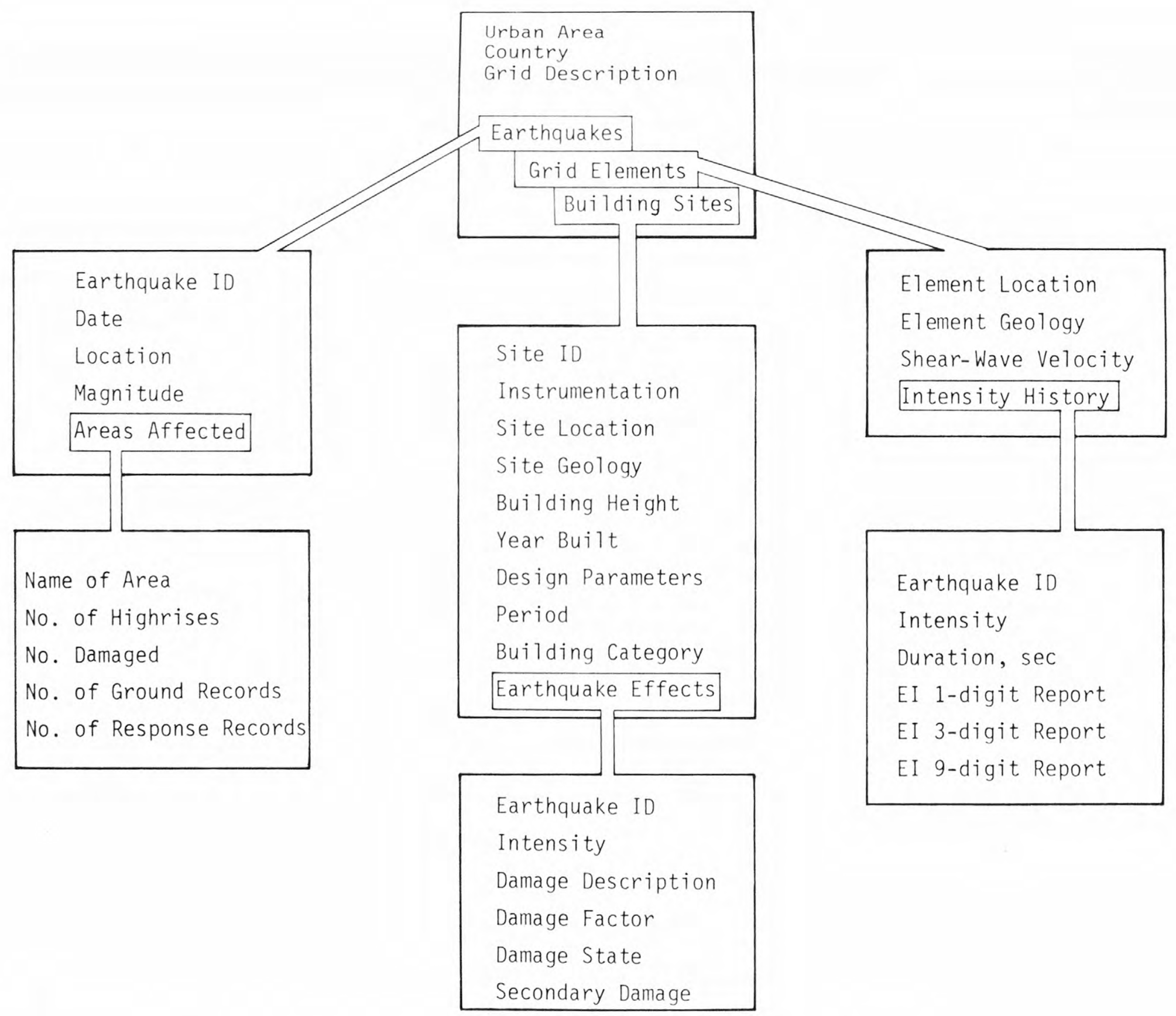

FIGURE 3.10 SCHEMATIC STRUCTURE OF DATA BASE HIRISE 


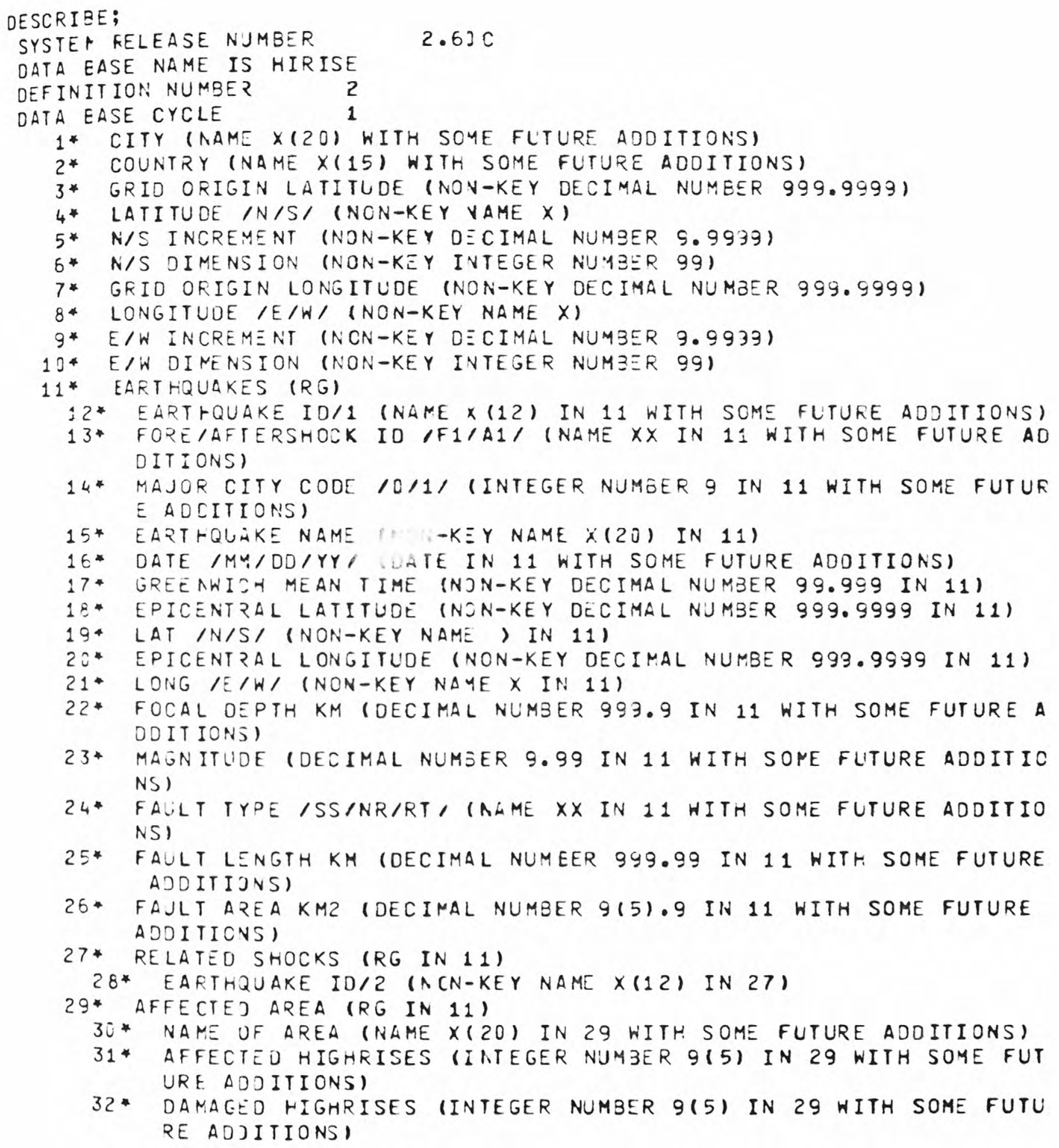


33* GROUN) MOTION RECCRDS (INTEGER NUMBER 9999 IN 29 WITH SOME FUTURE ADDITIONSI

34* RESPONSE RECORDS (INTEGER AUMBER 9999 IN 29 WITH SOME FUTUR E ADOITIONSI

35* SITE INFORMATION (RG)

$3 E$ * SITE ID (INTEGER NUMEER $9(5)$ IN 35 WITH SOME FUTURE ADDITIONS 1

37* INSTRUMENTATION /FF/LB/hB/HU/BU/HN/ INAME XX IN 35 WITH SOME FUTURE ADDITIONSI

38* SITE LO:ATION CODE /AZ2/H83/ (NAME XXX IN 35 WITH SOME FUTURE ADOITIONSI

39* Site LATITUDE (NON-KEY DECIMAL NUMBER 999.9999 IN 35)

40* SITE LONGITUDE (NON-KEY DECIMAL NUMBER 999.9999 IN 35)

41* SITE GEJLOGY/RK/LA/MA/DA/ (NAME XX IN 35 WITH SOME FUTURE AD DITIONSI

42* BUILDING ORIENTATION /V52W/ (NON-KEY NAME XXXX IN 35)

43* STORIES ABOVE GRADE (INTEGER NUMBER 999 IN 35 WITH SOME FUTUF E ADOITIONSI

44* STORIES BELOW GRADE (NON-KEY INTEGER NUMEER 9 IN 35 )

45* HEIGHT ABOVE GRADE M IJECIPAL NUMBER 999.9 IN 35 WITH SOME FU TURE AUJITIONSI

46* HEIGHT BELOW GRADE M (NCN-KEY DECIMAL NUMBER 99.9 IN 35 )

47* HEIGHT CODE /N/ (INTEGER NUMEER 9 IN 35 WITH SOME FUTURE ADDI TIONS)

48* HIOTH M (NON-KEY DECIMAL NUMEER 999.9 IN 35 )

49* LENGTH M (NON-KEY DECIMAL NUMBER 999.9 IN 35 )

5C* TOTAL FLOOR AREA M2 (NJN-KEY INTEGER NUMBER 9(7) IN 35)

51* YEAR OF CONSTRUCTICN (INTEGER NUMBER 9999 IN 35 WITH SOME FUT URE $\triangle D O I T I O N S I$

52* DESIGN $200 E$ IUBC46/CTHER/ (NON-KEY NAME X(5) IN 35)

53* LATEFAL DESIGN /SS/SW/RS/TH/CT/NO/ INAME XX IN 35 WITH SOME F UTURE ADOITIONS)

5:* 3ASE SHEAR L-G (DECIMAL NUMBER 9.999 IN 35)

55* EASE SHEAR T-J (CECINAL NUMBER 9.999 IN 35 )

56* MAXDESIJN SPECTRAL ACCL L-G (DECIMAL NUMEER 9.999 IN 35 WITH SOME FL'TUKE ADDITIONS)

57* MAXDESIGN SPECTRAL ACCL T-G IDECIMAL NUMBER 9.999 IN 35 WITH SOME FUTURE ADUITION'S)

58* DESIGN PERIOD L IDECIMAL NUMEER 99.99 IN 35 WITH SOME FUTURE ADDITIONSI

59* DESIGN DERIOD T IDECIMAL NUMEEP 99.99 IN 35 WITH SOME FUTURE ADDITICNS)

60* MEASURED PERIOD L (NCN-KEY DECIMAL NUMBER 99.99 IN 35 )

61* MEASUREJ PERIOD T (NON-KEY DECIMAL NUMBER 99.99 IN 35 )

62* MEASUREJ PERIOD TOR (NON-KEY DECIMAL NUMBER 99.99 IN 35 )

63* DATE MEASURED (NON-KEY INTEGER NUMBER 9999 IN 35)

FIGURE 3.11 (Continued) 
64* QUALITY FACTOR /N/ (INTEGER NUMBER 9 IN 35 WITH SOME FUTURE A DOITION:S)

E5* VERTICAL LOAD ISF/TR/BN/OT/ (NAME XX in 35 With SOME FUTURE A DDITIONS)

66* LATERAL LOAD L /MF/SH/SC/TF/EF/TB/OT/ (NAME XX IN 35 WITH SCM E FUTUR ( ADDITIONS)

67* LATERAL LOAD T/MF/SW/SC/TF/BF/TB/OT/ (NAME XX IN 35 WITH SOM E FUTURE ADOITIONSI

68* STRUCTLRAL MATERIAL /ST/RC/PC/RM/UM/WO/OT/SR/ (NAME XX IN $3 E$ WITH SOY FUTURE ACOITICNS)

69* ARCHITECTURAL EXTERIOR /CO/CB/CT/LP/OM/OW/GL/MT/OT/ INAME XX IN 3 E WITH SOME FLTURE ADOITIONS)

70* ARCHITECTUFAL INTERIOR /CO/CB/CT/LP/DM/OW/JL/MT/OT/ (NAME XX IN 35 WITH SOME FUTLRE ADOITIONS)

71* CONFIGURATION IRG/IR/ (NAME XX IN 35 WITH SOME FUTURE ADDITIO NS)

72* STRUCTURAL RIG IOITY IN/ (INTEGER NUMBER 9 IN 35 WITH SOME FUT URE ADOITIONSI

73* ARCHITECTURAL RIGIOITY /N/ I INTEGER NUMBER 9 IN 35 WITH SOME FUTUFE ADDITIONSI

74* GUILDINJ CATEGORY (NAME XX IN 35 WITH SOME FUTURE ADDITIONS)

75* EART HQLAKE EFFECTS (RG IN 35)

76* EARTHZUAKE IO/3 (NAME $X(12)$ IN 75 WITH SOME FUTURE ADOITION S)

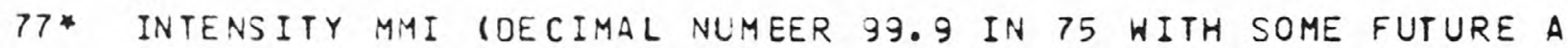
DDITIONSI

78* INTENSITY OTHER (NON-KEY DECIMAL NLMBER 99.9 IN 75)

79* INTENSITY SCALE/RFI/MKS/GEO/JMA/WO/ (NON-KEY NAME XXX IN 7 5)

80* REPJPTEO DURATION SEZ IINTEGER NUMBER 999 IN 75 WITH SOME F UTLRE ADOITIONSI

81* ESTIMATED DURATICN SEC (INTEGER NUMSER 999 IN 75 WITH SOME FUTURE ADOITIONS I

82* AVAILABLE RECURDS /RS5/RSO/THR/THC/THO/OTH/ (NAME XXX IN 75 WITH SOME FUTURE ADJITIONSI

83* MAXINTERSTORY ORIFT CM IDECIMAL NUMBER 99.9 IN 75 WITH SOME FUTURE AODITIONSI

84* CAUSE OF DAMAGE /SHK/FND/STL/SLP/FIR/ (NAME XXX IN 75 WITH SOME FUTURE AODITIONS)

85* Replacement COST \$ (NON-KEY INTEGER NUMBER $9(8)$ IN 75 )

86* DAMAGE REPAIR CCST \$ (NON-KEY INTEGER NJMBER 9 (8) IN 75 )

87* PERCENT STRUCTURAL IJECIMAL NUMBER 9.939 IN 75 WITH SOME FU TURE ADOITIONS)

FIGURE 3.11 (Continued) 
88* PERCENT ARCHITECTURAL (DECIMAL NUMBER 9.999 IN 75 WITH SOME FUTURE ADDITI (NS)

89* PERCENT MECH/ELEC (DECIMAL NUMZER 9.999 IN 75 WITH SOME FUT URE ADOITIONSI

90* DAMAGE FACTOR (DECIMAL NUMEER $9.9(5)$ IN 75 WITH SOME FUTURE ADOITIONS I

91* DAMAGE STATE /N/ (INTEGER NUMBER 9 IN 75 WITH SOME FUTURE A DOITIJNS)

92* DEATHS (NON-KEY INTESER NUMBER Y99 IN 75)

93* INJLRIES (NON-KEY INTEGER NUMBER 9999 IN 75)

94* LOSS JF FUNCTION B (INTEGER NUMBER 9(9) IN 75 WITH SOME FUT URE ADOITIONSI

95* CAUSE OF LOSS /ST/AR/ME/FR/ (NON-KEY NAME XX IN 75)

96* SITE EI Q-OIGIT (NCN-KEY INTEGER NUMBER 9(9) IN 75)

$97^{*}$ CITY GRID ELEMENTS (RG)

98* LOCATION CODE (NAME XXX IN 97 WITH SOME FUTURE ADDITIJNS)

99* ELEMENT LATITLDE (NOA-LEY DECIMAL NUMBER 939.9999 IN 97)

100 * ELEMENT LONG ITUDE (NON-KEY DECIMAL NUMBER 999.99@9 IN 97 )

101* SOIL TYPE /RK/LA/MA/DA/ (NAME XX IN 97 WITH SOME FUTURE AODIT IONS)

102* SHEAR WAVE VELOCITY M/SEC (NON-KEY INTEGER NUMBER 9(5) IN $9 \%$

$103^{*}$ INTENSITY HISTORY (RG IN 37)

104* EARTHQUAKE ID/4 (NAMEX(12) IN 103 WITH SOME FUTURE ADDITIO NS )

105* ELEMENT INTENS ITY MMI COECIMAL NUMBER 99.9 IN 103 WITH SOME FUTURE ADDITIONSI

106 * AVERAjE DURATION SEC IINTEGer Number 999 IN 103 WITH SOME F UTURE $\triangle D O I T I O N S I$

107* EI 1-DIGIT REPCRT (NON-KEY NAME $X X$ IN 103)

108 * EI 3-JIGIT REPCRT (NON-KEY NAME $X(8)$ IN 103 )

109* EI 9-JIGIT REPORT (NON-KEY NAME $X(11)$ IN 103)

110* EI1 (INTEGER NUMEER 3 IN 103 WITH SOME FUTURE ADDITIONS)

111* EI2 (INTEGER NUMEER 3 IN 103 WITH SOME FUTURE ADDITIONS)

112* EI3 (INTEGER NLMEER 3 IN 103 WITH SOME FUTURE AODITIONS)

113* EI4 (INTEGER NUMBER 3 IN 103 WITH SOME FUTURE ADDITIONS)

114* EI5 (INTEGER NUMSER 3 IN 103 WITH SOME FUTURE ADDITIONS)

115* EI6 (INTEGER NUMEER 3 IN 103 WITH SOME FUTURE ADDITIONS)

11 * EI7 (INTEGER NUMEER 3 IN 103 WITH SOME FUTURE ADDITIONS)

117* EIE (INTEGER NUMBER 3 IN 103 WITH SOME FUTURE ADDITIONS)

$11 \varepsilon^{*}$ EI $\subseteq$ (INTEGER NLIMEER 3 IN 103 WITH SOME FUTURE ADDITIONS)

FIGURE 3.11 (Continued) 
1.1 EARTHQUAKE

1.1.1 Earthquake Name: 15 *

1.1.2 Date: $\star 16$ *

1.1 .3 Origin Time: Local GMT $\star 17 \star$

1.1.4 Latitude: $\star 18 \star \star 19 \star(N / S) \quad$ Longitude: $\star 20 \star \star 21 \star(E / W)$

1.1.5 Depth $(\mathrm{km}): \star 22 \star$

1.1.6 Magnitude: $M_{L} \star 23 \star M_{S} \longrightarrow M_{b}$

1.1 .7 Type of Faulting: $\star 24 \star$ (S5) Strike Sizp (Nomaz (A) Reverse, Thrus

1.1 .8 Length of Surface Faulting $(\mathrm{km}): \star 25 \star$

1.1.9 10 of Significant Aftershocks (see separate form for each):

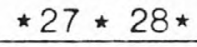

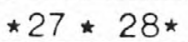

\subsection{EFFECTS}

1.2.1 Estimated Total Damage (U.S. \$ for Year of Earthquake):

1.2.2 Number of Deaths: Injuries:

1.2.3 Maximum Intensity: MMI RFI

$$
\text { Other (specify) }
$$

1.2.4 Land Area $\left(\mathrm{km}^{2}\right)$ : For MMI $\geq 4$ $M M I \geq 6$

1.2.5 Population in MMI $\geq 6$ Zone:

1.2.6 Number of Ground Motion Stations with Records: \#33*

\begin{tabular}{|c|c|c|c|c|c|}
\hline $\begin{array}{l}\text { Name of Town, } \\
\text { City, or } \\
\text { Urban Area }\end{array}$ & $\begin{array}{l}\text { Number of } \\
\text { High-Rise } \\
\text { Buildings } \\
\text { Affected } \\
\text { MMI } \geq 4\end{array}$ & $\begin{array}{l}\text { Number of } \\
\text { High-Rise } \\
\text { Buildings } \\
\text { Damaged }\end{array}$ & $\begin{array}{l}\text { Number of } \\
\mathrm{High}-\mathrm{Rise} \\
\text { Buildings } \\
\text { W/Recorded } \\
\text { Response }\end{array}$ & $\begin{array}{l}\text { Maximum } \\
\text { Intensity } \\
\text { (see } \\
1.2 .3 \text { ) }\end{array}$ & $\begin{array}{l}\text { Peak } \\
\text { Ground } \\
\text { Accel. } \\
\text { (g) }\end{array}$ \\
\hline$\star 29 \star 30 \star$ & $\star 31 \star$ & $\star 32$ * & $\star 34$ * & & \\
\hline$\star 29 \star 30$ * & $\star 31$ * & $\star 32$ * & $\star 34$ * & & \\
\hline & & & & & \\
\hline \multicolumn{6}{|l|}{ All Other } \\
\hline Total 1 29*30* & $\star 31 \star$ & $\star 32$ * & * 34 * & & \\
\hline
\end{tabular}

1.2.7 Principal Communities Involved: $\square$ City Maps $\square$ Aerial Photos

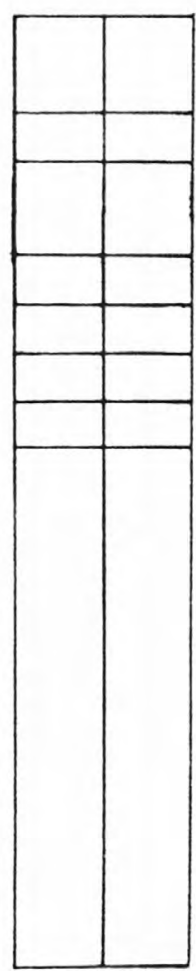

FIGURE 3.12 GENERAL EARTHQUAKE DATA (FORM 1) 
Site 10: $\star 35 \star 36 \star$

By: Date:

3.1 GENERAL SITE INFORMATION

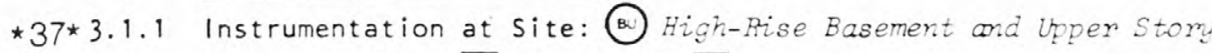
Ground Station: $\boxplus$ Free Field $\square$ Basement of Lowrise Building High-rise Building: Basement $\rightarrow$ Upper Story $\rightarrow$ None

3.1.2 Latitude: *39* Long i tude:

$\star 40$ *

3.1.3 Address:

3.2 SITE GEOLOGY

$\star 41 \star 3.2 .1$ Site Category:

$\rightarrow$ Rock $\square<10 \mathrm{~m}$ Alluvium Underlain by Rock

Alluvium $10-60 \mathrm{~m}$ of Alluvium Underlain by Rock

3.2.2 Average Specific Gravity:

3.2.3 Average Shear Wave Velocity: $\mathrm{m} / \mathrm{s}$, $\mathrm{ft} / \mathrm{sec}$

3.2.4 Depth of Water Table: m

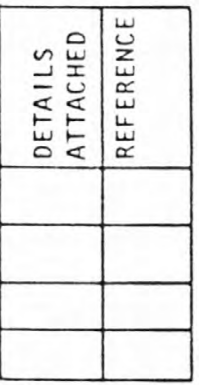

3.3 GENERAL BUILDING INFORMATION

3.3.1 Building Name:

3.3.2 Function/Occupation:

3.3.3 Building Orientation: $\star 42$ *

3.3.4 Number of Stories (above/below grade)

3.3.5 Height $(\mathrm{m})$ (above/below grade): $\star 43 \star / \star 44 \star$

3.3.6 Total Floor Area $\left(\mathrm{m}^{2}\right)$ : $\star 45 \star / \star 46 \star$

3.3.7 Year of Construction: $\star 50$ *

3.3.8 Construction Cost (U.S. \$):

3.4 BUILDING DESIGN AND CONSTRUCTION Code: $\star 52$ *

$\star 53 \star 3.4 .1$ Lateral Force Design Analys is Type: None Static Equivalent: ss Seismic wind Dynamic Analysis: $\rightarrow$ Response Spectrum Time History Other: (0)

3.4.2 Lateral Force Design Parameters:

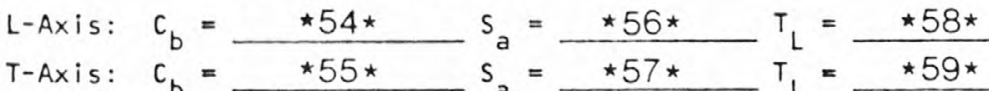

3.4.3 Building Period:

\begin{tabular}{|l|l|l|}
\hline & Measured & Date \\
\hline L-Axis & $\star 60 \star$ & $\star 63 \star$ \\
\hline$T$-Axis & $\star 61 \star$ & \\
\hline Torsion & $\star 62 \star$ & \\
\hline
\end{tabular}

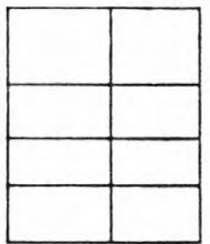

PZan Width $(\mathrm{m}): \frac{\star 48 \star}{\text { PZon Length }(\mathrm{m}):}$

FIGURE 3.13 SITE INFORMATION (FORM 3) 
4.1 Foundation:
$\square$ Wall Footing
$\square$ Combine Footing
$\square$ Mat or Raft Foundation
$\square$ Caissons

*65*4.2 Vertical Load-Support System:
SF Space Frame
Tr. Truss
4.3 Lateral Load-Resisting System

$\star 66 \star L$

$\star 67 \star T$

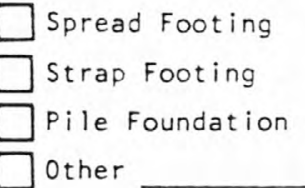

Bw Bearing Wall

0 Other

(L) Directions):

sw Shear Wall

$B$ Braced Frame

TB Tube

$\square$ Truss Frame

0 이 Other

4. 4 Floor System (describe):

$\star 68 \star 4.5$ Structural Material:
ST Steel
D Prestressed Concrete
A. Reinforced Concrete
Unreinforced Masonry
Rm Reinforced Masonry
wo wood

or Other

(SP) Steel Reinforced Concrete (Jacon)

4.6 Architectural Material ( $\square \square$ Exterior/Interior):

*69* Ext. 0 Concrete 0 Concrete Block

*60* Int. $\square$ Hollow Clay Tile $\square$ Lath and Plaster

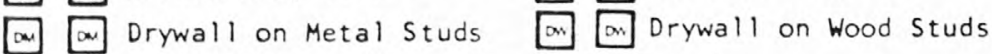

G. Glass Metal

or 0 other

*71*4.7 Configuration: PRegular DIrregular

(Discuss):

FIGURE 3.14 BUILDING CATEGORIZATION (FORM 4) 
Site 10:

By: Date:

Earthquake 10: $\star 75 \star 76$ *

FORM 2: MOTION AND DAMAGE DATA

2.1 MOTION AT SITE

2.1.1 Distance from Site to $(\mathrm{km})$ :

Epicenter Hypocenter

2.1.2 Site Intensity: MMI $\star 77 \star$ FRI

Other (specify) $\star 78 \star \star * 79 \star$

2.1.3 Peak Acceleration at Site $(\mathrm{g})$ : Estimated Recorded

\begin{tabular}{|c|c|c|c|c|}
\hline \multicolumn{2}{|c|}{$\begin{array}{c}\text { Recording } \\
\text { Instruments }\end{array}$} & \multirow{2}{*}{ Component } & Component & $\begin{array}{c}\text { Vertical } \\
\text { Component }\end{array}$ \\
\cline { 1 - 1 } Type & Location & & & \\
\hline & & & & \\
\hline & & & & \\
\hline
\end{tabular}

2.1.4 Duration of Motion Reported:

$\star 80$ *

*81* Estimated: $\square 15 \mathrm{sec} \square 30 \mathrm{sec} \square 60 \mathrm{sec} \square 120 \mathrm{sec}$

2.1.5 Available Data: () Other None

*82* Response Spectrum: $5 \%$ Damping, Tripartite 20 other Time History: $m$ Digitized GCorrected mother

2.1.6 10 of Nearest Recording Stations:

2.1.7 Maximum Interstory Displacement $(\mathrm{cm})$ : $\star 83$ *

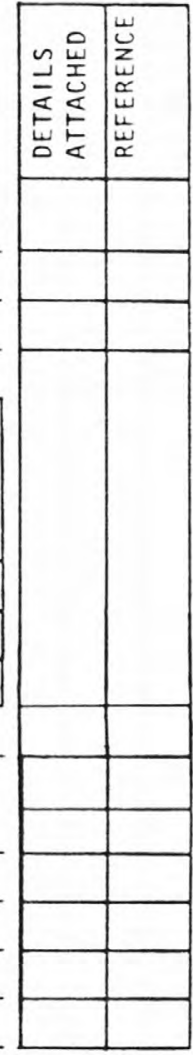

2.2 PRIMARY DAMAGE

2.2.1 Primary Cause of Damage: ENDFoundation Soil Failure Fire

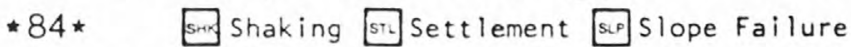

2.2.2 Replacement Cost (\$/Year): $\star 85$ *

2.2.3 Damage Repair Cost (\$/Year): * 86 *

2.2. Structural $\star 87 \star \approx$ Architectural $\star 88 \star \approx$ Mech. E Elec. $\star 89 \star \approx$

2.2.4 Damage Factor $(\xi)$ : $\quad 90$ *

2.2.5 Damage State: 0 No Damage $\star 91$ *

1 Negligible

3 Minor Structural

2 Minor Nonstructural

3 Substantial Nonstructural

6 Substantial Structura

4 Major Nonstructural

7 Major Structural

C Collapse or Condemnation

2.3 SECONDARY DAMAGE

2.3.1 Number of Deaths: « «

2.3.2 Loss of Building Function ( $\$ /$ Year): Injuries:

$\frac{\star 93 \star}{\star 94 \star}$

*95* Cause: ST Structural A Architectural Mech. E Elec. EI:

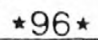

FIGURE 3.15 MOTION AND DAMAGE DATA (FORM 2) 


\subsection{Introduction}

This chapter describes work performed in relating seismological intensity to engineering intensity -- Task III of the overall study. Included are sections on purpose and general background, a description of the method used for correlating engineering intensity with seismological intensity, a discussion of work completed thus far, and a description of the work to be performed to complete this task.

\subsection{Purpose}

Records of strong ground motion have not been obtained for many important earthquakes; only seismological intensity data were available. Thus, there are numerous reports of damage for which no quantitative measure of ground motion exists. By developing general relationships between seismological intensity and engineering intensity, additional quantitative ground motion information can be developed for establishing motion-damage relationships for high-rise buildings.

\subsection{Background}

To engineers, it is obvious that damage must be related to a quantitative measure of ground motion to be of most use in reducing earthquake hazards. To others, it is not so obvious. This section is provided to elucidate the need for this correlation.

\subsubsection{Seismological Intensity (SI). Many scales have been developed} throughout the world over the past 200 years that are useful for communicating the effects of earthquakes. Because the development of these scales for rating seismological intensity preceded the development of ground motion instrumentation, the rating scales are inherently qualitative. All these scales indicate ground shaking intensity at a site and associate varying degrees of observable damage with arbitrary numerical values. 
The most common of the various seismological intensity scales are the modified Mercalli (MM), Rossi-Forel (RF), Medvedev-Sponheuer-Karnik (MSK), Japan Meteorological Agency (JMA), and GEOFIAN scales. Each of these is reproduced in Appendix $\mathrm{C}$ along with a discussion comparing them.

\subsubsection{Engineering Intensity (EI). The Engineering Intensity Scale (EIS)} was developed by Blume (1970) to serve as a systematic and orderly means of reporting the intensity of ground shaking at a site in a form useful to engineers.

In the formulation of the scale, ground shaking is characterized by $5 \%$-damped response spectrum velocity $\left(S_{v}\right)$, and structures are characterized by their fundamental-mode vibration properties. Disregarding mode shape considerations, the variables important for correlating ground motion with damage are $S_{v}$ amplitude and structure period $(T)$. A damping value of $5 \%$ is used because damping in many real structures varies from about $2 \%$ to $10 \%$, and $5 \%$ has become a standard reference level in investigations analyzing the response of structures to ground motion.

A comprehensive description of the EIS is given in Appendix D.

4.3.3 EI vis-a-vis SI for Damage Prediction. SI scales are defined in terms of damage observed at a site. The EIS defines ground motion response spectrum amplitude at a site. Whereas SI provides a qualitative estimate of ground motion, EI provides a quantitative measure of ground motion at a site. The most important advantage the EIS has over any of the SI scales is that the EIS reveals ground motion characteristics commonly used in the design of structures; thus, EI values can be used to perform engineering analyses of structures.

Seismological intensity scales have provided important information concerning ground shaking for past earthquakes, and it is likely that they will continue to be used in the future. Their principal shortcoming for purposes of damage prediction is that their basis is strictly qualitative. Any future changes in the design of structures to reduce earthquake hazards will undoubtedly result from engineering analyses. Because the damage scenarios 
associated with SI scales are based on empirical observations, it will take a long time of observing how structures perform during future earthquakes to change the scenarios to comply with engineering design changes. Earthquake engineering technology would thus be hindered if damage estimation and earthquake hazard reduction were constrained to function with only SI measures of ground shaking.

Currently, earthquake engineers are aware that different structures respond to the same ground motion in different ways. Similarly, it is most likely that the same structure will respond differently to different earthquakes. These variations are all accounted for within the context of dynamic response and associated amplification phenomena. The single most theoretically justifiable and intuitively palatable simple measure of dynamic response for engineering purposes that has been put forth thus far is the response spectrum. The important characteristics of earthquake ground motion, as it affects structure response and damage, are:

$$
\begin{aligned}
& \text { - Amplitude } \\
& \text { - } \text { - Drequency content } \\
& \text { - Periodicity }
\end{aligned}
$$

All these characteristics except for duration are reflected in standard response spectrum plots. Duration can be included using three-dimensional response spectrum plots (Schopp and Scholl, 1972), but, because the importance of duration has not been rigorously established, it is currently not done. These ground motion characteristics are also included in SI scales but are not independently distinguishable.

Most importantly, response spectrum plots facilitate distinguishing amplitude as a function of frequency. This is important in engineering because different structures have different natural frequencies and thus dynamic amplification for various structures depends on the amplitudes of ground motion at various frequencies. It is well known (Richter, 1958; McGuire, 1977) that the frequency content of earthquake motion depends on the magnitude of the earthquake, with earthquakes of larger magnitude producing more long-period effects. This trend is shown in Figure 4.1, which is the result of a statistical analysis of the effects of magnitude $(M)$ and distance (R) on spectral response. Because the SI scales combine both long- and short- 
period structure damage at a given intensity level, they are inherently biased toward a specified magnitude. The SI ratings assigned to damage to long-period structures (i.e., high-rises) would thus be lower for earthquakes of larger magnitude. It is therefore desirable when considering long-period structures to use the EIS because it facilitates accounting for the intensities at various period ranges.

Similar arguments can be put forth regarding the effects of site geology, fault type, etc., on the variation of ground motion amplitude as a function of frequency.

The EIS facilitates distinguishing ground motion amplitude as a function of frequency; the SI scales do not.

\subsection{Procedure for Correlating EI with SI}

Various approaches could be adopted for establishing relationships between SI and El. The method adopted for this project consists of collecting ground motion time-history records for which MMI reports are also available, calculating 5\%-damped response spectrum values, and performing correlation analyses. Details of the statistical procedures used in performing the correlation analysis are given in Appendix E.

As previously stated, shapes of ground motion spectra are functions (to varying degrees) of many seismological and geological factors (Trifunac and Brady, 1975). For example, Agbabian Associates (1977) have described spectra shapes accounting for various MMIs and several soil conditions, and McGuire (1977) has described variations in spectral shape considering the effects of magnitude and distance. One of the most difficult aspects of this task is to identify the important seismological and geological factors affecting ground motion.

The factors influencing the ground motion at any site begin with the faulting process and the associated stress regime. Parameters such as those from the source mechanism model -- stress drop, focal depth, source time history, and rupture length -- all affect the ground motion representation. The relative effect of each of these parameters is not yet fully known; research is currently being conducted to delineate the relative influence of each parameter. 
The next factor is the transmission path of the energy from the rupture surface to the recording site. Except for near-field sources, the transmission path of the energy is primarily through basement rock, with the effect being mainly one of attenuation of energy with distance. By contrast, in the near field, complexities in the geologic structure (e.g., nonhorizontal layering or high-contrast impedance boundaries) will affect the ground motion and its calculated response spectra. Focusing of energy by a particular orientation of fault plane with the site location may also affect the amount of seismic motion recorded at a site.

The final influencing factor is the geologic structure at the site. The site classification must consider the large-scale geologic structure down to the crystalline basement.

Because building damage is a nonlinear phenomenon, the duration of the ground motion will have an effect on the amount of damage, particularly for reinforced concrete, where there is degradation of stiffness with repetition and reversal of loads. An attempt will be made to address the effect of the duration of strong ground motion on the MMI-EIS correlation.

In accordance with the factors discussed above, the following is a list of information compiled or calculated for each ground motion record to be used in the correlation analysis:

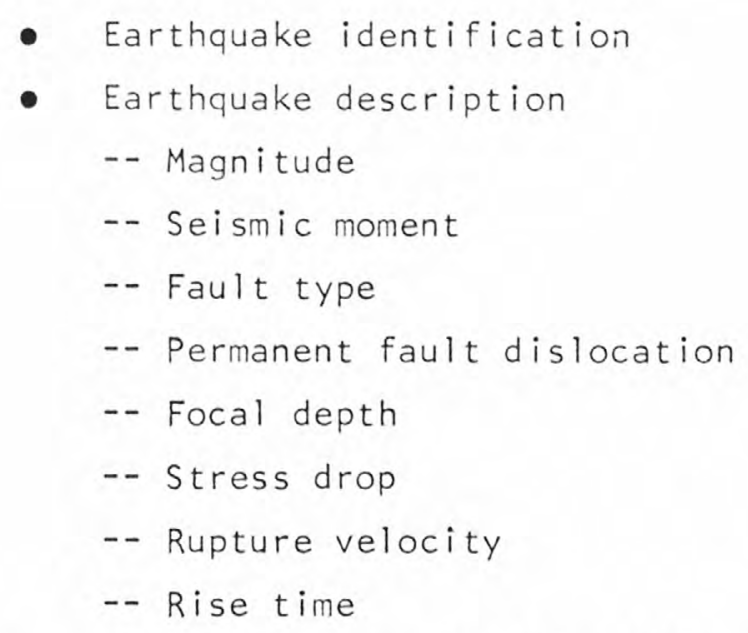


- Site MMI

- Site geologic description

-- Rock site outcrop

-- Rock site with thin alluvium: $t<10 \mathrm{~m}$

-- Alluvium: $10 \mathrm{~m}<t<60 \mathrm{~m}$

-- Deep alluvium: $t>60 \mathrm{~m}$

- Bracketed duration: acceleration $>0.05 \mathrm{~g}$

- Calculated $S_{v}$ and $S_{v}+1 \sigma$ values for 91 discrete periods in the range $0.04 \mathrm{sec} \leq t \leq 14.78 \mathrm{sec}$

- 9-digit El values

- 3-digit El values

- 1-digit EI value

Although this information can be used to sort in a multitude of ways, the principal correlations are MMI and EI values for various magnitudes and various site soil conditions.

\subsection{Work Completed}

The 1977 Agbabian Associates report summarizes the results of a correlation of MMI and response spectra for records of 372 horizontal components and 186 vertical components from the 1971 San Fernando, California, earthquake. Results of their investigation, without consideration of different site geology classifications, are reproduced in Figures 4.2 through 4.5 . The statistical correlation procedure used by Agbabian is the same as that described in Appendix E.

Tables 4.1 and 4.2 show correlations between EI and MMI as calculated from the Agbabian results.

\subsection{Additional Studies for Project Completion}

The spectra in Figures 4.2 through 4.5 are 1 imited to MMI values of V, VI, and VII. The data base described in Chapter 2 indicates that damage data are available for MMI values as high as XI. Accordingly, more data are required to perform statistical analyses for the higher intensities.

Table 4.3 lists various strong-motion records that URS/Blume has acquired for use in this task. The final product of the task will be plots similar 
to those in Figures 4.2 through 4.5 and a tabulation of El versus MMI values similar to those in Tables 4.1 and 4.2 .

Finally, an attempt will be made to develop damage scenarios for various El values for high-rise buildings similar to those now available for si scales. The EIS currently lacks any such scenarios. 
TABLE 4.1

CORRELATION OF MMI AND EI USING DATA FROM THE

1971 SAN FERNANDO EARTHQUAKE -

5\% DAMPING, LOGNORMAL MEAN $S$,

\begin{tabular}{|c|c|c|}
\hline $\begin{array}{c}\text { Direction } \\
\text { of Motion }\end{array}$ & MMI & EI \\
\hline Vertical & V & $233,333,333$ \\
& & $3-, 3,3$ \\
Vertical & VI & $233,344,443$ \\
& & $3-, 4-, 4-$ \\
Vertical & VII & $3+$ \\
& & $334,455,554$ \\
& & $4+, 5-$ \\
Horizontal & V & $234,444,443$ \\
& & $3,4,4-$ \\
& & $4-$ \\
Horizontal & VI & $344,455,454$ \\
& & $4-, 5-, 4+$ \\
& & $4+$ \\
Horizontal & VII & $345,555,665$ \\
& & $4,5,6-$ \\
& & 5 \\
\hline
\end{tabular}


TABLE 4.2

CORRELATION OF MMI AND EI USING DATA FROM THE

1971 SAN FERNANDO EARTHQUAKE -

5\% DAMPING, LOGNORMAL 84TH-PERCENTILE $S v$

\begin{tabular}{|c|c|c|}
\hline $\begin{array}{l}\text { Direction } \\
\text { of Motion }\end{array}$ & MMI & EI \\
\hline Vertical & V & $\begin{array}{c}233,333,443 \\
3-, 3,4- \\
3\end{array}$ \\
\hline Vertical & VI & $\begin{array}{c}334,444,444 \\
3+, 4,4 \\
4-\end{array}$ \\
\hline Vertical & VII & $\begin{array}{c}345,555,554 \\
4,5,5- \\
5-\end{array}$ \\
\hline Horizontal & V & $\begin{array}{c}234,444,444 \\
3,4,4 \\
4-\end{array}$ \\
\hline Horizontal & VI & $\begin{array}{c}345,555,555 \\
4,5,5 \\
5-\end{array}$ \\
\hline Horizontal & VII & $\begin{array}{c}345,666,665 \\
4,6,6- \\
5+\end{array}$ \\
\hline
\end{tabular}


TABLE 4.3

STRONG-MOTION RECORDS AVAILABLE ON MAGNETIC

TAPE FOR USE IN CORRELATING MMI AND EI

\begin{tabular}{|c|c|c|c|}
\hline \multicolumn{2}{|c|}{ Earthquake Identification } & \multirow{2}{*}{$\begin{array}{c}\text { Epicentral } \\
\text { MMI }\end{array}$} & \multirow{2}{*}{$\begin{array}{c}\text { Number of } \\
\text { Records }\end{array}$} \\
\hline Location & Date & & \\
\hline Long Beach, California & $3 / 10 / 33$ & IX & 3 \\
\hline Southern California & $10 / 2 / 33$ & VI & 2 \\
\hline Eureka, California & $7 / 6 / 34$ & V & 1 \\
\hline Helena, Montana & $10 / 31 / 35$ & VIII & 3 \\
\hline Lower California & $12 / 30 / 34$ & IX & 1 \\
\hline Humboldt Bay, California & $2 / 6 / 37$ & -- & 1 \\
\hline Northwest California & $9 / 11 / 38$ & VI & 1 \\
\hline Imperial Valley, California & $5 / 18 / 40$ & $X$ & 1 \\
\hline Northwest California & $2 / 9 / 41$ & -- & 1 \\
\hline Santa Barbara, California & $6 / 30 / 41$ & VIII & 1 \\
\hline Northern California & $10 / 3 / 41$ & VII & 1 \\
\hline Torrance-Gardena, Cal ifornia & $11 / 14 / 41$ & VIII & 2 \\
\hline Borrego Valley, California & $10 / 21 / 42$ & VII & 1 \\
\hline Northern California & $3 / 9 / 49$ & VII & 1 \\
\hline Western Washington & $4 / 13 / 49$ & VIII & 2 \\
\hline Imperial Valley, California & $1 / 23 / 51$ & VII & 1 \\
\hline Northwest California & $10 / 7 / 51$ & VII & 1 \\
\hline Kern County, California & $7 / 21 / 52$ & XI & 5 \\
\hline Northern California & $9 / 22 / 52$ & VII & 1 \\
\hline Southern California & $11 / 21 / 52$ & VII & 1 \\
\hline Imperial Valley, California & $6 / 13 / 53$ & VII & 1 \\
\hline Wheeler Ridge, California & $1 / 12 / 54$ & VIII & 1 \\
\hline Central California & $4 / 25 / 54$ & VII & 1 \\
\hline Lower California & $11 / 12 / 54$ & $\mathrm{~V}$ & 1 \\
\hline Eureka, California & $12 / 21 / 54$ & VII & 2 \\
\hline San Jose, California & $9 / 4 / 55$ & VII & 1 \\
\hline Imperial County, Cal ifornia & $12 / 16 / 55$ & VII & 1 \\
\hline El Alamo, Baja California & $2 / 9 / 56$ & -- & 2 \\
\hline Southern California & $3 / 18 / 57$ & VI & 1 \\
\hline
\end{tabular}


TABLE 4.3 (Continued)

\begin{tabular}{|c|c|c|c|}
\hline \multicolumn{2}{|c|}{ Earthquake Identification } & \multirow{2}{*}{$\begin{array}{c}\text { Epicentral } \\
\text { MMI }\end{array}$} & \multirow{2}{*}{$\begin{array}{l}\text { Number of } \\
\text { Records }\end{array}$} \\
\hline Location & Date & & \\
\hline San Francisco, Cal ifornia & $3 / 22 / 57$ & VII & $\left.\frac{5}{(3-a f t e r s h o c k}\right)$ \\
\hline Central California & $1 / 19 / 60$ & VI & 1 \\
\hline Northern California & $6 / 5 / 60$ & VI & 1 \\
\hline Hollister, California & $4 / 8 / 61$ & VI I & 2 \\
\hline Northern California & $9 / 4 / 62$ & VI & 1 \\
\hline Puget Sound, Washington & $4 / 29 / 65$ & VIII & 2 \\
\hline Southern California & $7 / 15 / 65$ & VI & 1 \\
\hline Parkfield, California & $6 / 27 / 66$ & VII & 7 \\
\hline Gulf of California & $8 / 7 / 66$ & VI & 1 \\
\hline Northern Cal ifornia & $9 / 12 / 66$ & VII & 1 \\
\hline Northern California & $12 / 10 / 67$ & VI & 2 \\
\hline Northern California & $12 / 18 / 67$ & VI & 1 \\
\hline Borrego Mountain, California & $4 / 8 / 68$ & VII & 13 \\
\hline Lytle Creek, California & $9 / 12 / 70$ & VII & 7 \\
\hline San Fernando, California & $2 / 9 / 71$ & XI & 101 \\
\hline Central California & $3 / 8 / 71$ & $\mathrm{~V}$ & 1 \\
\hline Andreanof Islands, Alaska & $5 / 1 / 71$ & VI & 1 \\
\hline Central Chile & $7 / 8 / 71$ & $x$ & $\begin{array}{c}1 \\
(1 \text { component })\end{array}$ \\
\hline Northern California & $9 / 12 / 71$ & V & 1 \\
\hline Southeast Alaska & $7 / 30 / 72$ & VII & 1 \\
\hline Central California & $9 / 4 / 72$ & VI & 3 \\
\hline Managua, Nicaragua & $1 / 3 / 72$ & -- & 3 \\
\hline Managua, Nicaragua & $12 / 23 / 72$ & IX & 3 \\
\hline Gazli, USSR & $5 / 17 / 76$ & -- & 1 \\
\hline Ruman ia & $3 / 4 / 77$ & IX & 1 \\
\hline Oroville, California & $8 / 11 / 75$ & VII & 14 \\
\hline Friuli, Italy & $5 / 76$ & IX & 26 \\
\hline Coyote Lake, California & $8 / 6 / 79$ & VII & 6 \\
\hline Imperial Valley, California & $10 / 15 / 79$ & IX & 22 \\
\hline Oaxaca, Mexico & $11 / 29 / 78$ & VI I I & 4 \\
\hline
\end{tabular}




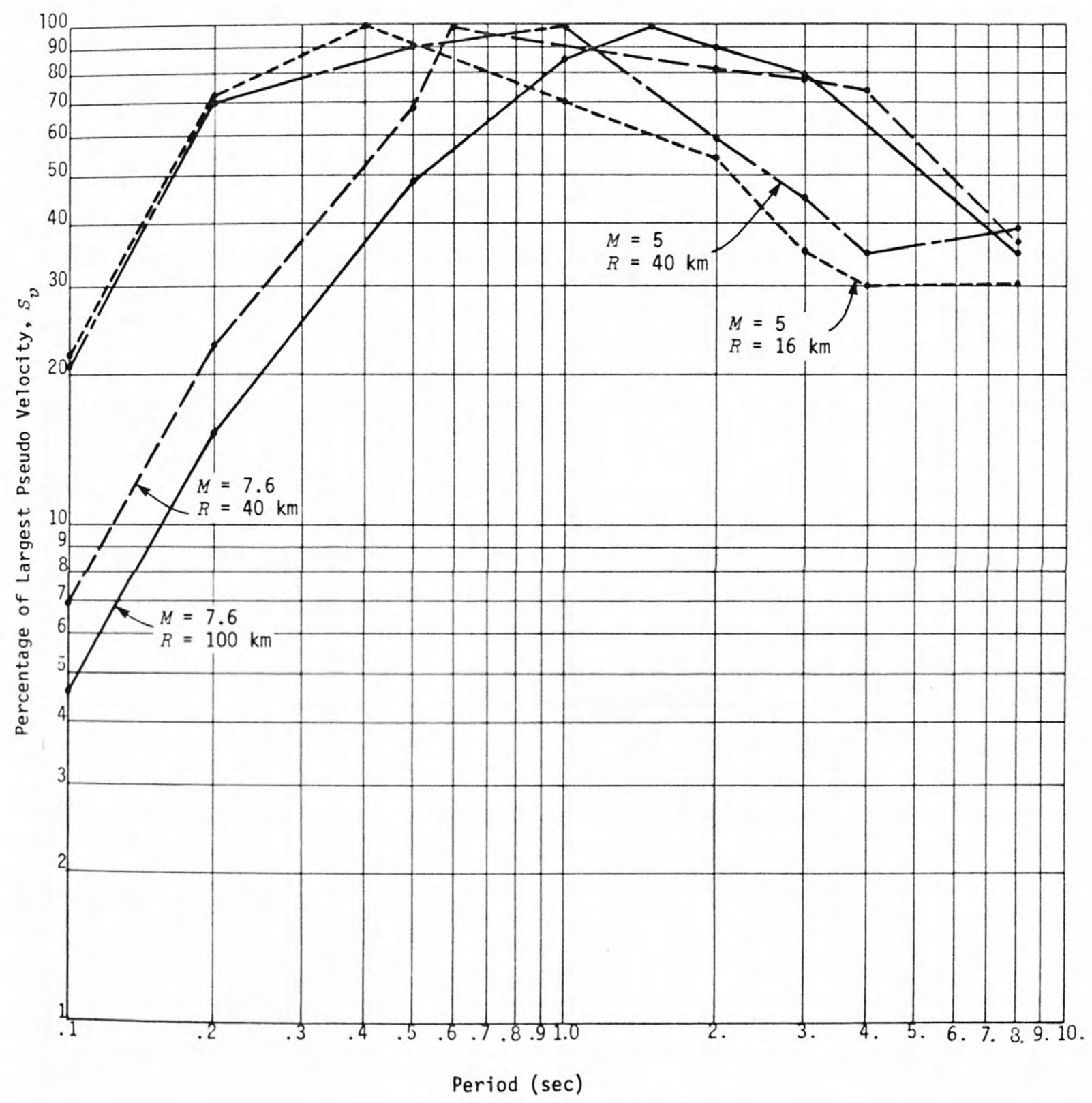

FIGURE 4.1 PREDICTED SPECTRAL PSEUDO VELOCITIES FOR EARTHQUAKES OF SEVERAL MAGNITUDES AND DISTANCES (AFTER MCGUIRE, 1977) 
FREQUENCY - HZ

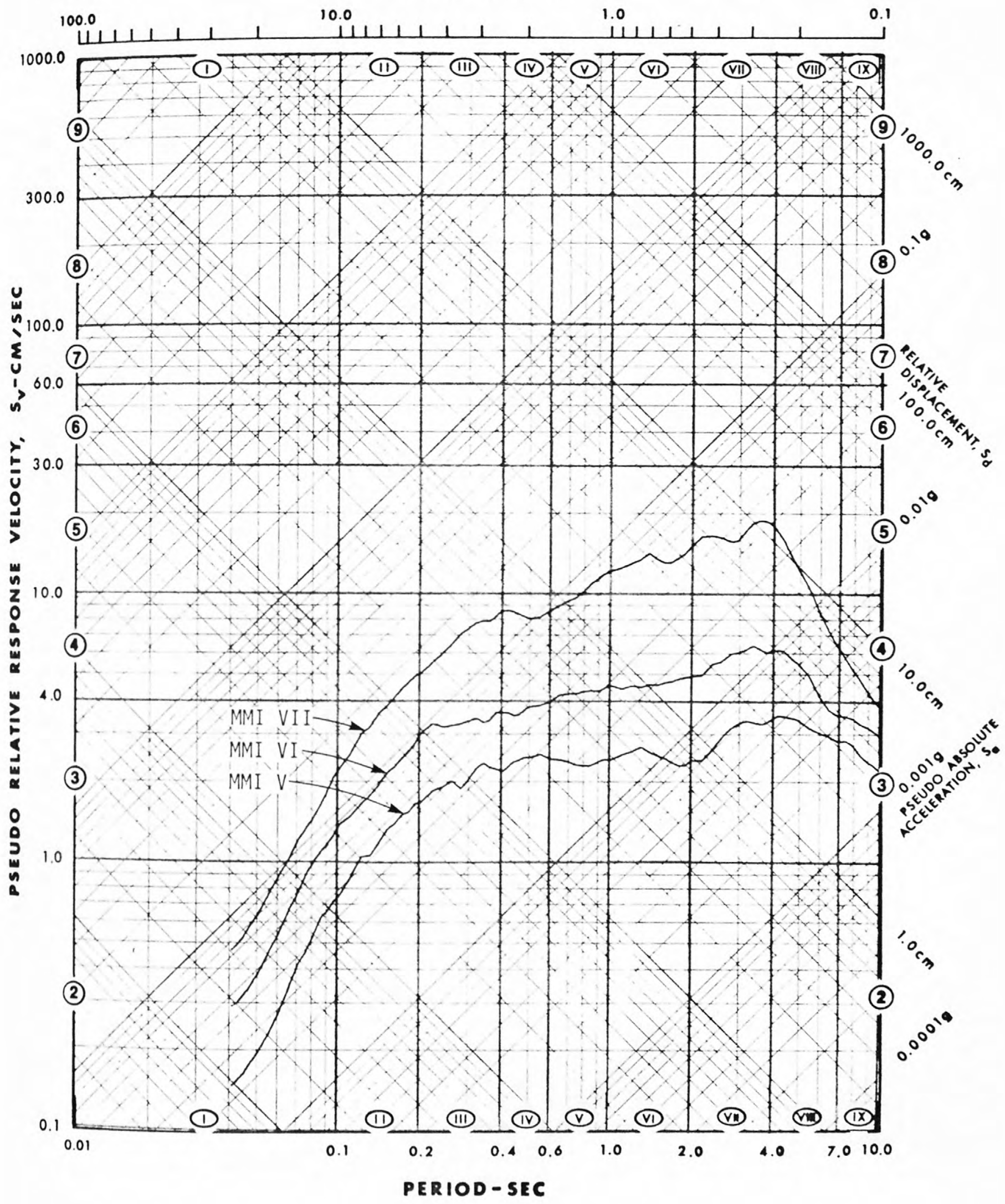

FIGURE 4.2 LOGNORMAL MEAN VERTICAL SPECTRA FOR MMI V, VI, AND VII $5 \%$ DAMPING 
FREQUENCY - H Z

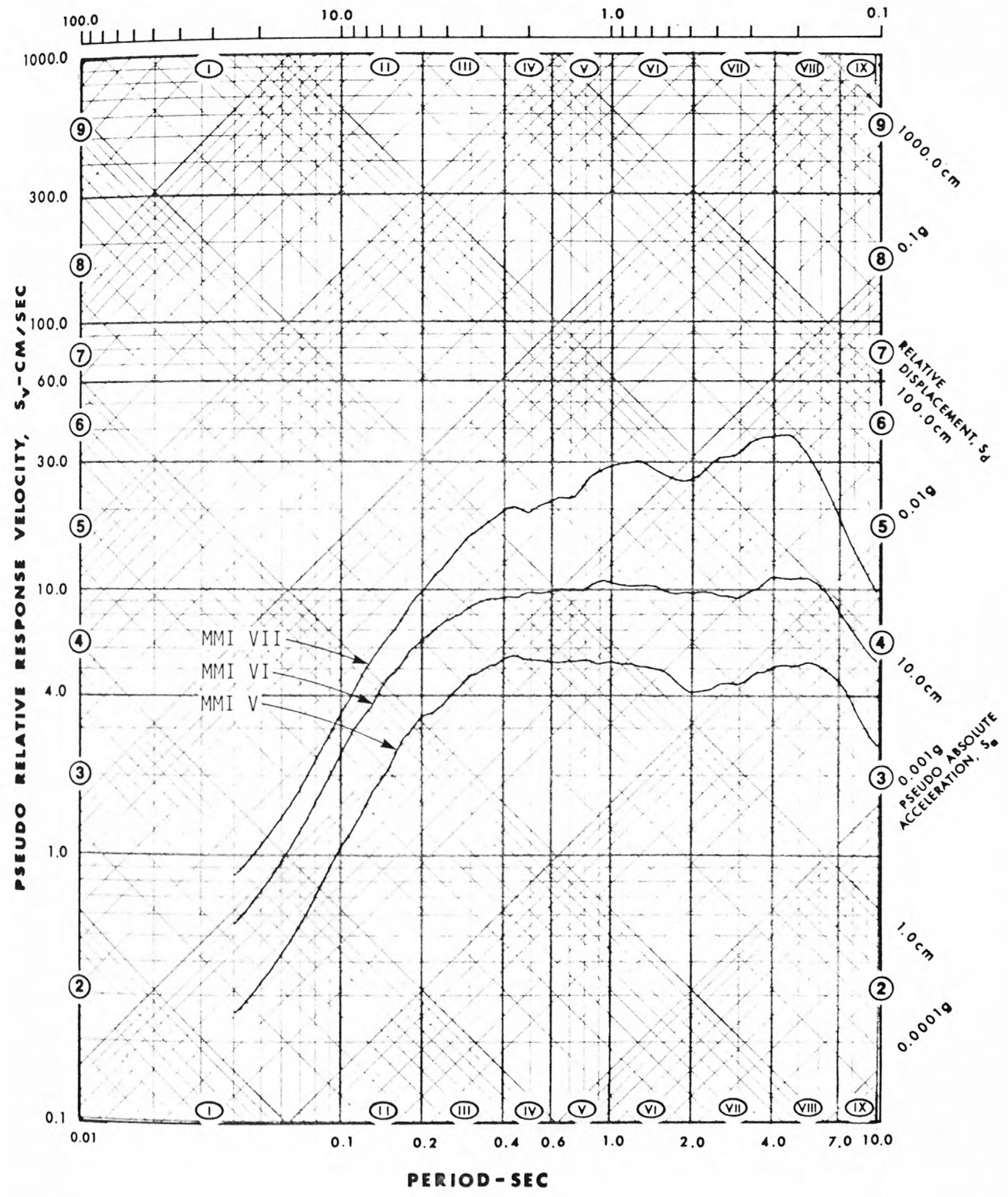

FIGURE 4.3 LOGNORMAL MEAN HORIZONTAL SPECTRA FOR MMI V, VI, AND VII $5 \%$ DAMPING 
FREQUENCY - H Z

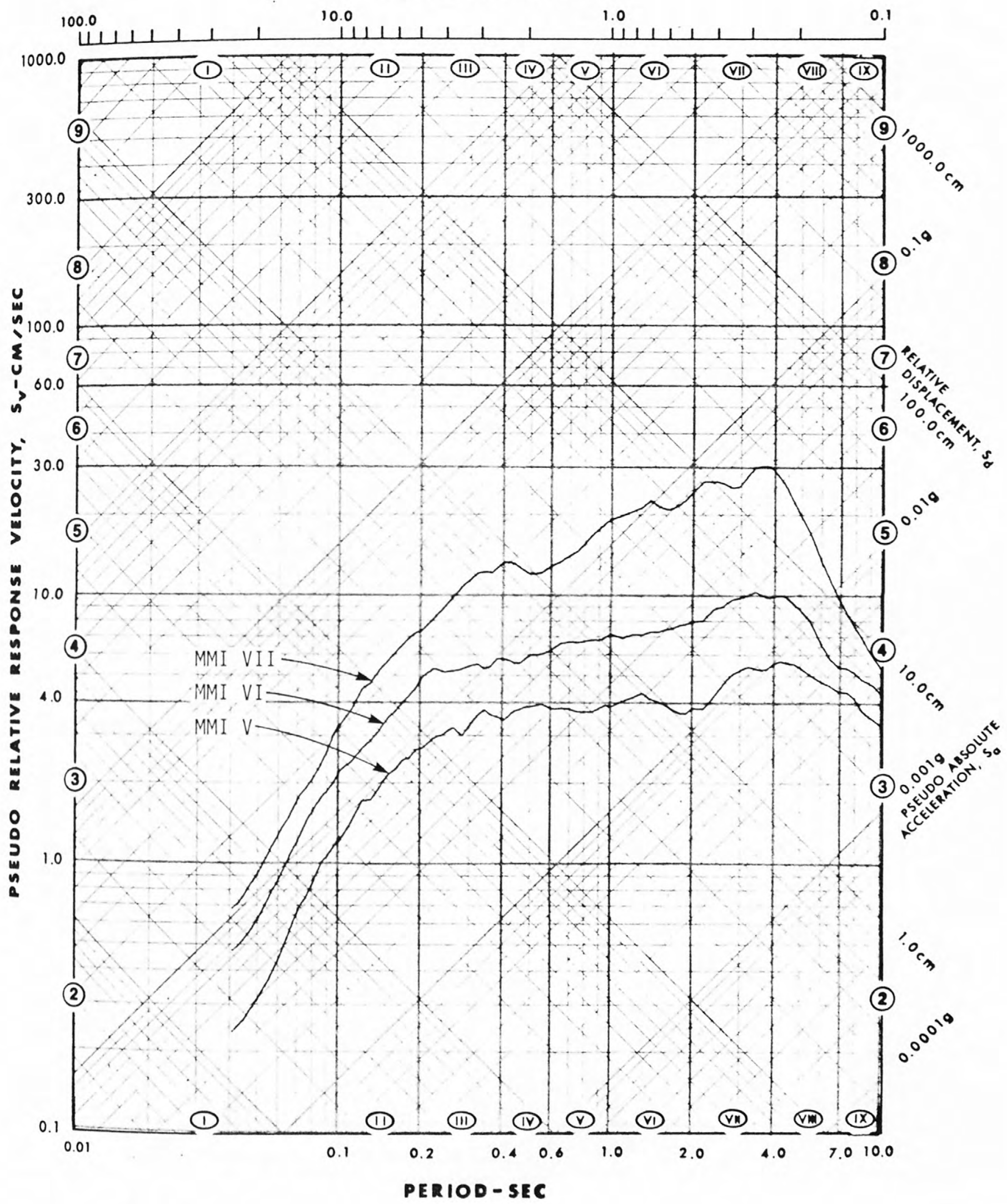

FIGURE 4.4 LOGNORMAL 84TH-PERCENTILE VERTICAL SPECTRA FOR MMI V, VI, AND VII - 5\% DAMPING 
FEEQENCY - HZ

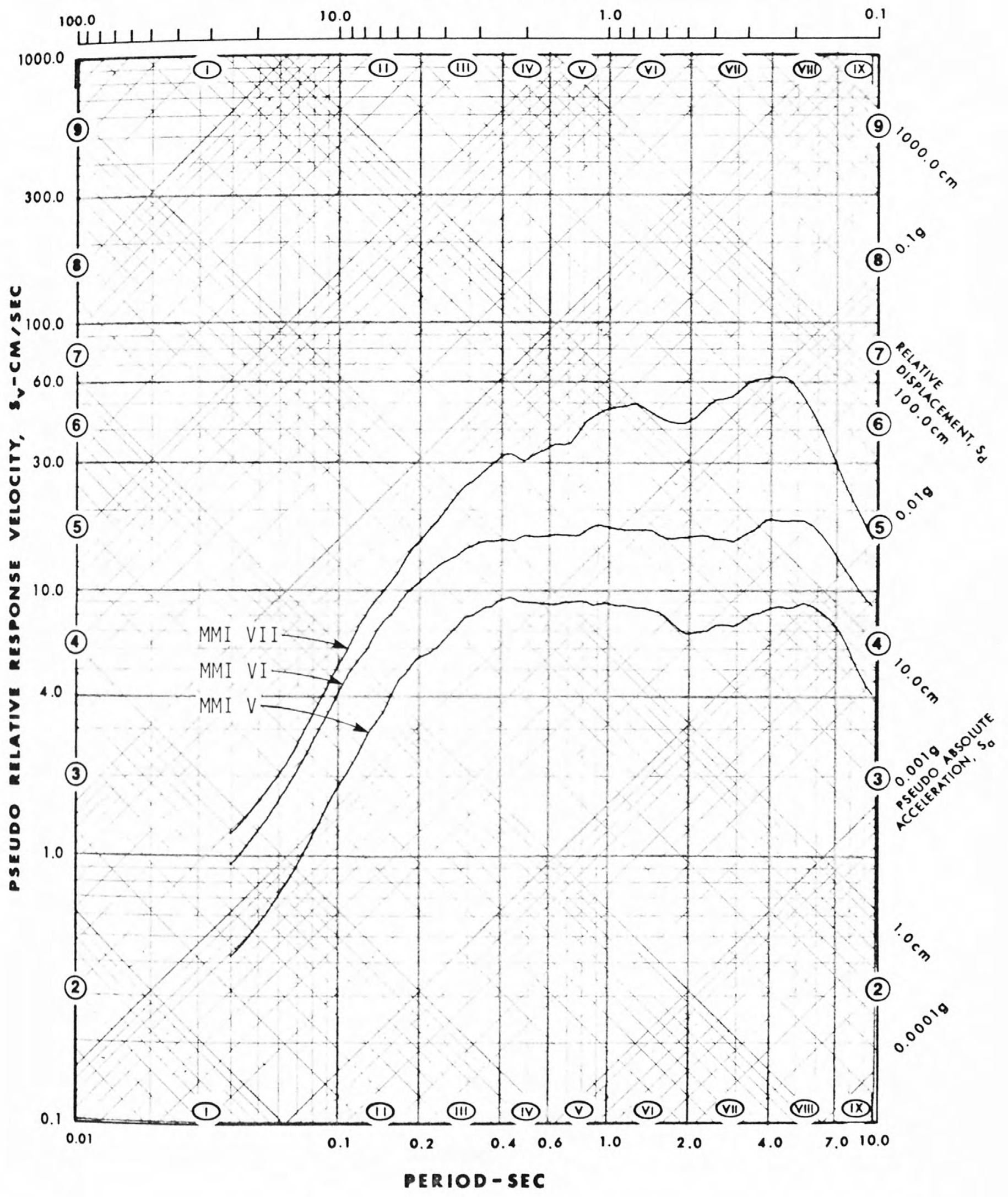

FIGURE 4.5 LOGNORMAL 84TH-PERCENTILE HORIZONTAL SPECTRA FOR MMI V, VI, AND VII - 5\% DAMPING 


\section{THEORETICAL MOTION-DAMAGE RELATIONSHIPS}

\subsection{Introduction}

Structural analysis technology for prediction of earthquake response has advanced significantly in the past 15 years. Linear dynamic response analyses are commonplace today, and nonlinear dynamic response analyses are feasible for simple structures. These procedures are used for calculating structure member stresses and strains and are correspondingly used in design (i.e., structure members are sized by comparing calculated stresses and strains with those allowed by codes).

Unfortunately, the codes do not specify the degree of damage associated with various prescribed stresses and strains. In addition, the stated philosophy of contemporary earthquake design procedures (Structural Engineers Association of California, 1979) is that structures are expected to be damaged during major earthquakes but that collapse is to be precluded by using the recommendations prescribed. Finally, because structures are expected to be damaged during major earthquakes, they will respond nonlinearly. Therefore, nonlinear response considerations must be included in any attempt to relate response and damage.

As indicated in Chapter 1, various researchers have begun developing methods for estimating damage to structures. A few have used structural response analysis concepts, but much work is still needed to develop a comprehensive methodology. Task IV of this project is directed toward furthering earthquake engineering technology by developing methods for predicting damage using fundamental structural response analysis concepts. Only through such developments will structural designers come to understand what amplitude of response causes a particular degree of damage.

The work of this task is divided into two major activities: (1) detailed analysis of high-rise buildings damaged by earthquakes and (2) approximate theoretical motion-damage relationships. 
The first activity was conducted to facilitate a detailed understanding of the manner in which a structure responds while experiencing damage. Nonlinear response is particularly important in this regard. The second activity is an attempt at consolidating various types of information currently available from various sources in order to establish a theoretical basis for predicting damage.

\subsection{Detailed Response Analysis of Damaged Buildings}

The overall objective of this study is to predict and evaluate the correlation of ground motion and damage to high-rise buildings. To help accomplish this goal, detailed structure response and damage data from high-rise buildings that were instrumented at the time of damaging earthquakes is being used to relate building damage and seismic motion.

The first buildings to be analyzed were the Bank of California Building and two Holiday Inn buildings, all of which experienced both structural and nonstructural damage during the San Fernando earthquake of February 9, 1971 (John A. Blume \& Associates, 1973). The roof, an intermediate floor, and the ground floor of the buildings were equipped with SMA-1 strong-motion accelerographs.

The first step of this study was to match the response time histories recorded on an intermediate floor and the roof of the building with response time histories calculated using the recorded first-floor ground acceleration. Because damage may have significantly changed structural behavior, record analyses were necessary to detect nonlinearities in the structural responses. In order to reasonably match the recorded and calculated response time histories, certain changes in the analysis models had to be made and justified.

\subsection{Detailed Response Analysis of the Bank of California Building}

5.3.1 Building Description. The Bank of California Building is a 12-story reinforced concrete structure located in the Sherman Oaks district of Los Angeles, California. The site is approximately $17 \mathrm{miles}$ south of the epicenter of the San Fernando earthquake. 
Typical plan dimensions of the floors are $60 \mathrm{ft}$ by $161 \mathrm{ft}$, except at the first floor, where plan dimensions are $90 \mathrm{ft}$ by $161 \mathrm{ft}$. Typical story height is 13 $\mathrm{ft}$, with the exception of a $16-\mathrm{ft}$ height for the first story. A mechanical penthouse covers $30 \%$ of the main roof area, which stands $159 \mathrm{ft}$ above the ground floor. Typical plans and sections are shown in Figures 5.1 through 5.4 .

The structure was designed in 1969, under the requirements of the 1968 Los Angeles city building code, and was completed in 1970 at a cost of $\$ 4$ million. Except at the lower levels, where some shear walls are located, lateral forces in both directions are resisted by moment-resisting reinforced concrete frames consisting of columns and girders. All the moment-resisting frames on the exterior extend to the full height of the structure. However, interior frames in both directions were designed to be moment-resisting only from the ground to the third floor. Above the third floor, interior columns continue to the roof and are considered to be non-moment-resisting because beams framing into these columns are merely wide joists, with reinforcement designed to carry only vertical loads.

Two shear walls, each two stories high, rise along column line 1, A 1-storyhigh separation wall rises along column line 4 , adjacent to the property 1 ine. This wall serves as a shear wall. Locations of these shear walls may be found on the ground-floor plan (Figure 5.1).

Spandrel beams are set back above the third floor 16-1/2 in. from the column lines of the longitudinal frame along column 1 ine 1 and from the column lines of the transverse frames along column Iines $A$ and 1 . This offset is 43 in. at the typical second-floor girders. In addition, along column 1 ine 3 between the ground floor and the second floor, alternate columns have been omitted between $\mathrm{I}$ ines $\mathrm{C}$ and $\mathrm{H}$.

Typical floor construction consists of a 4-1/2-in. slab on a 17-in.-deep panjoist system spanning from girder to girder. Lightweight concrete was used for all floor and girder construction. Rectangular tied columns, built with regular-weight stone-aggregate concrete, support the girders. The properties of the materials used in the construction are given in Tables 5.1 and 5.2. 
Soil at the site is primarily silt and silty sand, with lesser deposits of clay and sand. A typical soil boring log is shown in Figure 5.5. The shear wave velocities of the subsurface materials were investigated to a depth of $320 \mathrm{ft}$ by conventional downhole geophysical methods (Figure 5.6). Inhole testing was accomplished by measuring the travel time of polarized shear waves from a source at the surface to three multiple-component geophones coupled inside the casing. The testing methods are presented in the report by Shannon \& Wilson (1978).

Since silt and silty sand, the upper soils at the site, are only moderately firm and would tend to become weaker and more compressible when wet, pile foundations were provided. Column footings and pile foundations are shown on the foundation plan in John A. Blume \& Associates (1973). Piles shown on the foundation plan are drilled and cast-in-place concrete piles 35 to $50 \mathrm{ft}$ long.

Earthquake Damage. The San Fernando earthquake caused both structural and nonstructural damage to the Bank of California Building. All the damage was repairable. Structural damage consisted of both concrete cracking and spalling of columns, spandrel beams, girders, and a parapet wall at the first story. Nonstructural damage to partitions, ceilings, stairwells, stairs, mechanical equipment, and to some furnishings resulted. Repair costs were approximately $\$ 44,000$.

Visible structural damage, generally, was slight and consisted almost entirely of minor cracking and spalling of concrete. Nevertheless, extensive cracking occurred in some areas, particularly at the exposed parts of girders between the spandrel beams and exterior columns along the second-floor level, where torsional effects were induced. At the penthouse level, slight spalling of patched concrete was observed where the exterior penthouse walls joined the penthouse columns. Between the sixth and eleventh floors, there was minor spalling on some east and west columns at the floor line on the inside face of the building.

Exterior columns typically spalled at the floor levels of the third, fourth, and fifth floors. Spalling also occurred on the interior face at the top of the 
columns on the east and west sides of the building. Some slight spalling of spandrel beams showed up near these columns. Although interior columns, at the same levels, experienced no damage, a series of cracks occurred in the slab around the columns.

The typical spandrel-beam-column detail, which facilitated construction from the fourth floor to the roof, provided the main bottom reinforcing for the spandrel without confining stirrups within the column zone. Major joint rotation and column or spandrel-beam spalling occurred in areas where this detail was used.

At the second floor, the typical floor plan changes. Some of the exterior columns along column line 3 do not extend to the first floor below, and a 1-story low-roof structure is attached at the east side by means of a parapet. At the juncture of the parapet and office building columns, cracking occurred because the seismic separation joint was poured monolithically during construction. Girders projecting beyond the spandrel line were damaged at the secondfloor level. The torsion induced in girders between spandrel beams and columns on the north and south sides caused major cracking in these zones. Girders on the west side showed some bending cracks in the same zones.

The east wall of the 1-story structure showed horizontal cracks at construction joints, but no other damage or shear cracks were observed. The drilled and cast-in-place pile foundation seemed to perform satisfactorily. No noticeable foundation distress, settlement, or overturning effects were observed.

Nonstructural damage was widespread between the sixth and eleventh floors. The east-west gypsum wallboard on steel stud partitions was fastened to both the floor and the suspended ceiling. As the partitions pulled away from the east and west exterior columns, ceiling tiles fell out.

In the mechanical penthouse, a compressor mounted on an inertia block came off its spring support. Other equipment, such as the cooling tower and chiller units, were little affected. 
5.3.2 Instrumentation. Three SMA-1 triaxial accelerographs, serial No. 185, manufactured by Kinemetrics, Inc., were the strong-motion instruments used in this building. The station was established on February 1, 1971, by the Seismological Field Survey Unit of NOAA's National Ocean Survey. It is listed by Perez and Schwartz (1973) as USGS Station No. 466. The accelerometers have the following specifications:

\begin{tabular}{|c|c|c|c|}
\hline Component & Orientation & $\begin{array}{l}\text { Sensitivity } \\
(\mathrm{cm} / \mathrm{g}) \\
\end{array}$ & $\begin{array}{r}\text { Period } \\
(\mathrm{sec}) \\
\end{array}$ \\
\hline Long i tud inal & $\mathrm{N} 11^{\circ} \mathrm{E}$ & 1.98 & 0.041 \\
\hline Vertical & Down & 1.70 & 0.038 \\
\hline Transverse & $\mathrm{N} 79^{\circ} \mathrm{W}$ & 1.78 & 0.039 \\
\hline
\end{tabular}

The locations of the three SMA-1 triaxial accelerographs in the building--on the roof, the seventh floor, and the ground floor--can be found on the floor plans in Figures 5.1 to 5.4 .

Approximately $28 \mathrm{sec}$ of motion of the San Fernando earthquake were recorded. The recorded time histories and associated response spectra are presented in Figures 5.7 to 5.9. These time histories and response spectra have been digitized by the California Institute of Technology.

5.3.3 Record Analysis. The recorded time histories at the three different floor levels of the Bank of California Building were used as original data for extracting the building's natural frequencies, damping ratios, and mode shapes in the elastic range. While the structure was being damaged during the earthquake, the structural response became nonlinear. In other words, during the earthquake, the structural frequencies and damping ratios changed. The relationship between the ground time histories and the response time histories can be represented by instantaneous transfer functions of the structural response.

The transfer function $T E j$ at node $j$ can be written as:

$$
T F_{j}(i \omega)=\frac{X_{j}(i \omega)}{E(i \omega)}
$$


where:

$$
\begin{aligned}
\omega= & \text { circular frequency } \\
X_{j}(i \omega)= & \begin{array}{l}
\text { Fourier transform of the recorded relative } \\
\text { response at node } j
\end{array} \\
E(i \omega)= & \begin{array}{l}
\text { Fourier transform of the forcing function, } \\
\text { i.e., the recorded ground motion }
\end{array} \\
i= & \text { imaginary constant, } i^{2}=-1
\end{aligned}
$$

The response time history at the seventh floor in the transverse direction was selected for transfer function calculation because the mass and the rigidity centers are approximately coincident, which eliminates, or at least minimizes, the torsional effects during the earthquake.

Two different approaches were used for the calculation of transfer functions. In the first approach, $10-\mathrm{sec}$ segments of the time histories were used to generate the transfer function. If the structure stays within the elastic range, the dominant structural frequencies should be steady for all segments. To eliminate the instability in numerical analysis, time-history segments were overlapped. The plots of the variation of fundamental period shown in Figures 5.10 (cases 1 through 7) and 5.11 show that the structural fundamental period was approximately $1.8 \mathrm{sec}$ and shifted to around $3.5 \mathrm{sec}$ at about $22 \mathrm{sec}$. This indicates that the structural members were damaged at about this time.

In the second approach, the transfer function was calculated for the time interval from the beginning of the earthquake up to certain chosen times in the time history. Again, it is possible to conclude from the results (Figure 5.10 , cases A through $G$ ) that nonlinearity occurred after the first 22 sec of the earthquake.

Figure 5.12 shows plots of the transfer functions for each case in Figure 5.10. A smoothing technique was employed in the generation of the transfer functions to eliminate possible noises recorded in the time histories.

\subsubsection{Detailed Structural Analysis. Several mathematical models were used} in determining the dynamic properties of the structure. Mode shapes, periods, and participation factors were calculated for each model using the TABS 
(Wilson and Dovey, 1972) computer progrem. Two of these models are described below.

The first structural model attempts to duplicate the structure's response in its initial stage of vibration, which is considered to be within the range of linear elastic material properties. Therefore, all frames, including those designed to carry only vertical forces, were modeled.

In the longitudinal direction, three 12-story frames, one large shear wall, and two small pieces of 2 -story shear walls contribute to the lateral stiffness of the structure. The frames stand on column 1 ines 1, 2, and 3 . The interior frame on 1 ine 2 has an interior bay width twice as large as those of the exterior frames on 1 ines 1 and 3 . A 1 -story single-piece shear wall runs along column line 4, while the other two 2-story shear walls, each with the width of a bay, stand on 1 ine 1 .

In the transverse direction, there are nine 12-story frames on column lines $A$ to 1 . With the exception of the exterior frames on 1 ines $A$ and 1 , which have five typical bays $12 \mathrm{ft}$ in width, each frame has two bays $36 \mathrm{ft}$ and 24 $\mathrm{ft}$ in width. These frames contribute to the lateral stiffness of the structure. The principal axes of the central columns of the frames on lines $D, E$, and $F$ are different from those of the exterior columns.

The stiffness of the pan-joist floor systems spanning from girder to girder was not taken into account in either direction. However, because TABS assumes rigid diaphragms, the in-plane stiffness of the floor system was treated as infinite.

The resultant dynamic properties were, in turn, used as input to another computer program for generating response time histories and graphic plots. These theoretical plots are shown in Figure 5.13 along with the time histories actually recorded during the earthquake. Structural mode shapes and periods are shown in Figure 5.14 .

The second model includes only those structural systems that were designed specifically for resisting lateral forces. It was developed in an effort to reconcile structural responses with actual recordings in the last stage of vibration, when the building was already damaged. 
In this model, two frames, one shear wall, and two small 2-story shear walls constitute the whole lateral-load-resisting system in the longitudinal direction. The frames are on 1 ines 1 and 3 , and the frame on 1 ine 1 contains two 2-story shear walls 11-1/2 ft in width. The 1-story-high shear wall on line 4 remains the same as in model 1 .

In the transverse direction, only two exterior frames, those on column lines $A$ and 1 , were considered as a lateral-load-resisting system.

Elevation views of the four main frames are shown in Figures 5.15 through 5.17. Frames 1 and 3 were used to represent moment-resisting frames in the longitudinal direction for both Model 1 and Model 2, while frames A and I were used in the transverse direction.

Analysis of Model 2 showed a fundamental period of $3.0 \mathrm{sec}$, which closely approximates the $3.3 \mathrm{sec}$ measured in the building. Figure 5.18 shows the analytical results and recorded time histories for both the longitudinal and the transverse directions.

\subsubsection{Study of Interstory Drifts. Dynamic analyses of the two computer} models were performed using TABS. The results of these analyses, such as structural frequencies, mode shapes, and participation factors, were used in calculating interstory drifts due to the earthquake.

For Model 1, which simulates linear response of this structure, damping ratios of $3 \%$ and $5 \%$ of critical damping were used for the fundamental mode and higher modes, respectively. Because it was concluded that the structure frequencies shifted at about $22 \mathrm{sec}$ into the earthquake, information shown on plots after $22 \mathrm{sec}$ for Model 1 is inconsequential.

For Model 2, a damping ratio of $5 \%$ of critical damping was used for the fundamental mode, and $7 \%$ was used for higher modes in order to reconcile the theoretical response with the recorded nonlinear response time histories. To avoid interference of the 1 inear response with the nonlinear response, ground motion from 0 to $18 \mathrm{sec}$ was truncated: Model 2 was subjected to $40 \mathrm{sec}$ of ground acceleration motion with $18 \mathrm{sec}$ of zero motion. 
Figure 5.19 shows the maximum interstory drifts throughout the height of the building for both Model 1 and Model 2 .

Average interstory drifts between all floors, for both models, were also calculated as follows:

$$
\overline{\Delta u}=\sqrt{\frac{1}{N} \sum_{i=1}^{N} \Delta u_{i}^{2}}
$$

where:

$$
\begin{aligned}
D & =\text { number of stories } \\
\Delta u_{i} & =\text { interstory drift at } i \text { th floor level } \\
\frac{\Delta u}{\Delta u} & =\begin{array}{l}
\text { quantity describing average interstory } \\
\text { drift }
\end{array}
\end{aligned}
$$

Figures 5.20 and 5.21 show plots of average interstory drifts calculated using Equation (5.2) along the building height for Models 1 and 2, respectively.

\subsection{Detailed Response Analysis of the Holiday Inn Building}

5.4.1 Building Description. The Holiday Inn on Orion Avenue is a 7-story reinforced concrete structure with typical plan dimensions of about $62 \mathrm{ft}$ by $160 \mathrm{ft}$. The structure is located about 13 miles south of the epicenter of the San Fernando earthquake. It was designed in 1965 and constructed in 1966 at a cost of roughly $\$ 1.3$ million. It is essentially identical to the Holiday Inn on Marengo Street, for which the dynamic analysis is in progress.

Except for two small areas of the ground floor, which are covered by one-story canopies, the plan configurations of each floor, including the roof, are the same. The typical framing consists of columns spaced at $20-f t$ centers in the transverse direction and 19-ft centers in the longitudinal direction. Spandrel beams surround the perimeter of the structure. The floor system is a reinforced concrete flat slab, $10 \mathrm{in.}$ thick at the second floor, 8-1/2 in. thick at the third to seventh floors, and $8 \mathrm{in}$. thick at the roof. A penthouse with mechanical equipment covers approximately $10 \%$ of the roof area. 
Interior partitions, in general, are gypsum wallboard on metal studs. The north side of the building has four bays of brick masonry walls located between the ground floor and the second floor at the east end of the structure. Nominal 1-in. expansion joints separate these walls from the exterior columns, and nominal 1/2-in. expansion joints separate them from the underside of the second-floor spandrels.

5.4.2 Earthquake Damage. Costs for repairing the damage caused by the earthquake were approximately $\$ 145,000$. Structural repair amounted to less than $\$ 2,000$; the remainder was for nonstructural damage.

Nonstructural damage was observed in almost every guest room. About $80 \%$ of the repair cost was spent on drywall partitions, bathroom tiles, and plumbing fixtures. The damage was most severe on the second and third floors and least severe on the sixth and seventh floors.

5.4.3 Record Analysis. The recorded acceleration time histories at three different floor levels of the building were used as original data for extracting the dynamic properties of the structure, such as vibration frequencies, damping ratios, and mode shapes, in the linear elastic range. However, since the structure was damaged during the earthquake, the structural response became nonlinear, which means that the structural frequencies and damping ratios changed within the duration of motion.

The instantaneous transfer function technique described for the Bank of California Building study was employed to estimate the time when the structure went into the nonlinear response stage by using successive windows along the entire length of the records. Variations in the dominant periods in the longitudinal and transverse directions can be seen in Figures 5.22 and 5.23 , respectively.

For both the longitudinal and the transverse directions, the first peak of the transfer function plots shifted toward a lower period after about 15 to $20 \mathrm{sec}$, which implies that the structural responses stayed in the linear elastic range up to about $15 \mathrm{sec}$. 
5.4.4 Study of Interstory Drift. Figures 5.24 through 5.27 are average interstory-drift plots for Models 1 and 2 . The drift in the transverse direction reached its maximum value at about $12 \mathrm{sec}$; in the longitudinal direction, the maximum occurred at about $13 \mathrm{sec}$. Figures 5.23 and 5.29 show the maximum interstory drifts for each floor of the building.

The nonstructural damage reported for almost all guest rooms was most severe on the second and third floors and least severe on the sixth and seventh floors. The interstory drift plots reveal this phenomenon consistently. Lower floors experienced larger interstory displacement than upper floors did, reflecting the pattern of distribution of nonstructural damage caused by the earthquake.

5.4.5 Additional studies. At the time of this report, work was continuing on a detailed nonlinear analys is of this Holiday Inn building; the other Holiday $\operatorname{lnn}$ building was in the stage of system identification.

\subsection{Approximate Theoretical Motion-Damage Relationships}

Any theoretically based damage prediction will have certain simplifying assumptions. Observations of damage from severe earthquakes commonly reveal that design inadequacies (e.g., inadequately tied structure members) are common causes of catastrophic failures. At the outset, it will be assumed that these inadequacies do not exist. After the basic development has been put forth, which puts high-rise damage into perspective, it will be seen that these types of inadequacies can be taken into account through statistical variability.

5.5.1 General Considerations for Predicting Damage. A comprehensive damageprediction methodology should satisfy the following criteria:

- It should be based on sound theory and engineering principles, and it should relate to and use commonly known engineering analysis and design methods and parameters. This would allow improvements to be made easily in the damage-prediction methodology as the state of the art in engineering design and analysis advances. It would also facilitate the use of the methodology by most practicing professionals without requiring extensive experience with damageprediction technology. 
- The methodology should be easily adaptable to all engineering structures. This criterion will be satisfied if the methodology is based on engineering principles and uses commonly known design and analysis methods and parameters.

- The methodology should have provisions for using the data from actual earthquakes and from laboratory experiments as they become available.

- Uncertainties in the ground motion demand, the structural capacity, and the analytical methods and assumptions should be accounted for. This requires the methodology to adopt a probabilistic approach.

- The methodology should be able to be conveniently automated for use of computers in real-world applications. This requires a modular structuring of the methodology. Basic modules, for example, can be ground motion prediction, structure response prediction, structure (or component) inventory, basic damage prediction, and economic factors. In addition, a decision analysis module can also be incorporated. The structure response - damage relationships or data can be stored as a separate module or as a damage data library.

Existing methodologies that attempt to correlate directly a subjective ground motion intensity, such as 1 MII, with overall damage or loss do not satisfy most of these criteria. They basically provide an expanded definition of the subjective intensity scale they use, and, therefore, the predictions are as good as the experience and judgment of the person making the prediction.

Classification of structures presents another serious problem for some of the existing methodologies. Structures are usually classified as high-rise, lowrise, concrete, steel, etc. This type of classification is made necessary partly because these methodologies try to estimate the total damage to the structures under consideration without any regard to the components of the damage, i.e., damage to plaster, walls, columns, foundation, glass, or contents. No consensus exists among various investigators regarding how best to classify structures for damage prediction.

One possible way of resolving the structure classification problem is to estimate damage to components of structures rather than trying to estimate total damage. The number of components, such as beams, walls, and windows, used in constructing engineering structures are finite compared to the 
infinite number of combinations (i.e., independent structures) that can be built using these components. Also, extensive theoretical and experimental work has been done to study the behavior of components. If needed, further component data can easily and inexpensively be obtained from laboratory experiments. If such an approach is adopted, and the basic methodology is developed, the remaining task would be systematically to develop component damage behavior data and form a data base or library.

Considering the advantages and disadvantages of the various existing damageprediction methodologies, the following methodology has been synthesized and is being further developed as part of the current study.

The damage to a structure will be obtained by adding the damage to its modules or pieces. For a high-rise building, the most convenient module is a story or floor level. For each module, the damage will consist of the summation of the damage to its components.

The suggested damage components for high-rise buildings are:

- Structural damage

-- Steel frame

-- Concrete frame

- Concrete shear wall

-- Masonry shear wall

- Braced frames

-- Foundations

- Nonstructural damage

-- Drywall partitions

-- Brick infill walls

-- Concrete block infill walls

-- Glazing

-- Cladding

-- other (ceilings, mechanical and electrical equipment)

- Damage to contents 
For each one of these damage components, motion-damage relationships will be developed. For all structural damage (except foundations), dry wall partitions, brick and concrete block walls, and glazing, the motion parameter should be the maximum interstory drift. For cladding and other nonstructural damage, maximum floor acceleration or velocity could be the motion parameter. Damage to contents should most likely be related to maximum floor accelerations.

The motion-damage relationships for brittle elements, such as glazing, can be derived from typical geometry and from design practices. Test results can be used to verify these calculations. For ductile components, the various threshold values can be calculated analytically or derived from experiments, or certain assumptions can be made for the motion-damage relationships. Eventually the objective would be to develop and improve a library of component motion-damage relationships. Information from the data base will be used to verify and improve these relationships.

All components at a floor level will have the same maximum response (or demand), which will be either the interstory drift at that level or the maximum velocity or acceleration. The response parameters will be obtained from a dynamic analysis of the structure for the given ground motion. It should be noted that the prediction of the floor response parameters through a dynamic analysis of the structure is quite independent of the damage-prediction methodology and can be accomplished by any qualified professional using various available structural analysis techniques, such as response spectrum analysis or timehistory analysis. The analytical model and the analysis method used can be as sophisticated as judged to be necessary for the problem under consideration.

If the approach described is taken, statistics for the replacement values of building components, as precentages of the total value, must be collected for various types of buildings. Of course, for the study of an individual building, this information can be obtained from the contract documents or can be estimated by contractors.

A step-by-step application of this methodology would follow the flow chart shown in Figure 5.30 . 
5.5.2 Theoretical Motion-Damage Relationships for Various Types of Buildings. Using the concepts described in the preceding section, motion-damage relationships are presented here for various types of buildings. The specific methodology used is tentative and is subject to change during the third year of this project. The basic concepts are firm, however.

As stated in the preceding section, damage to most structural and nonstructural components of a building can be related to interstory drift, and component test data are available or can be estimated for many types of structure configurations. Accordingly, information such as that indicated in Table 5.3 can be determined.

The interstory drift information can then be used to calculate response spectrum amplitudes for the various drift limits as follows. From fundamental considerations of dynamic response analysis, and considering only the fundamental mode response:

$$
\delta_{\text {roof }}=S_{d}^{\gamma}
$$

where:

$$
\begin{aligned}
\delta_{\text {roof }}= & \text { displacement of the roof relative to the ground } \\
S_{d}= & \text { response spectrum displacement } \\
\gamma= & \text { modal participation factor for fundamental mode } \\
& \text { with roof displacement normalized to unity }
\end{aligned}
$$

Then, assuming:

1. building period $T=0.1 \mathrm{~N}$, where $N$ is the number of stories

2. straight-line mode shape

it follows that:

$$
\Delta u=\frac{\delta \text { roof }}{N}=\frac{r S_{d}}{N}
$$

where:

$$
\Delta u=\text { average interstory drift }
$$


Finally:

$$
S_{d}=\frac{N \Delta u}{y}
$$

Equation (5.5) facilitates plotting various interstory drift limits onto a response spectrum plot. In that form, damage can be crudely estimated by comparing a demand ground motion response spectrum with various structure component capacities developed from interstory drift limits. The calculated $S_{2}$ values for the example assumed drift limits in Table 5.3 are given in Table 5.4. These $S_{d}$ values are plotted in Figure 5.31, which also shows a plot of the 5\%-damped response spectrum for the 1940 El Centro earthquake record.

\subsection{Additional Studies for Project Completion}

The following additional work will be performed in connection with this task during Phase III.

- More succinct conclusions relating to nonlinear response will be derived from the detailed response analyses (e.g., changes in frequency and damping).

- Structure component test data will be reviewed to complete response spectrum plots of damage for various types of structure framing and nonstructural elements. Plots for equipment damage will be attempted. Variability of damage will be established where possible. 
TABLE 5.1

BANK OF CALIFORNIA BUILDING - PROPERTIES OF CONCRETE

\begin{tabular}{|l|c|c|c|c|}
\hline \multicolumn{1}{|c|}{ Member Type } & Aggregates & $\begin{array}{c}\text { Unit } \\
\text { Weight } \\
\text { (pcf) }\end{array}$ & $\begin{array}{c}f_{c}^{\prime} \\
(p s i)\end{array}$ & $\begin{array}{c}E \\
(p s i)\end{array}$ \\
\hline Columns & regular weight & 150 & 4,000 & $3.9 \times 10^{6}$ \\
$\begin{array}{c}\text { Beams, Joists, } \\
\text { and Slabs } \\
\text { Foundation }\end{array}$ & lightweight & 110 & 3,000 & $2.1 \times 10^{6}$ \\
\hline
\end{tabular}

TABLE 5.2

BANK OF CALIFORNIA BUILDING -

PROPERTIES OF REINFORCING BARS

\begin{tabular}{|l|c|c|c|}
\hline Location & Grade & $\begin{array}{c}f_{y} \\
(\mathrm{ksi})\end{array}$ & $\begin{array}{c}E \\
(\mathrm{psi})\end{array}$ \\
\hline $\begin{array}{l}\text { Walls, Slabs, Ties, } \\
\text { and Stirrups }\end{array}$ & 40 & 40 & $29 \times 10^{6}$ \\
All Other & 60 & 60 & $29 \times 10^{6}$ \\
\hline
\end{tabular}


TABLE 5.3

INTERSTORY DRIFT LIMITS FOR VARIOUS STRUCTURE TYPES

\begin{tabular}{|c|c|c|c|}
\hline \multirow{2}{*}{$\begin{array}{l}\text { Lateral-Force- } \\
\text { Resisting System }\end{array}$} & \multicolumn{3}{|c|}{$\begin{array}{c}\text { Interstory Drift } \\
(\mathrm{cm})\end{array}$} \\
\hline & $\begin{array}{l}\text { Observable } \\
\text { Damage, } \Delta u_{1}\end{array}$ & $\begin{array}{c}\text { Yield } \\
\text { Capacity, } \Delta u_{2}\end{array}$ & $\begin{array}{l}\text { Ultimate } \\
\text { Capacity, } \Delta u_{3}\end{array}$ \\
\hline $\begin{array}{l}\text { Wood Frame } \\
\text { Unreinforced Masonry } \\
\text { Reinforced Masonry } \\
\text { Reinforced Concrete } \\
\text { Frame } \\
\text { Reinforced Concrete } \\
\text { Shear Wall } \\
\text { Steel Frame } \\
\text { Steel Braced Frame } \\
\text { Steel Eccentrically } \\
\text { Braced Frame }\end{array}$ & $.25 *$ & $1.0 *$ & $5.0 *$ \\
\hline
\end{tabular}

*Values assumed for this example. As further data are obtained, appropriate values can be filled in for each structure type. 


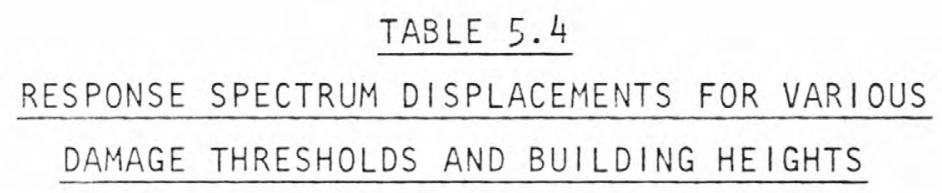

\begin{tabular}{|c|c|c|c|c|c|}
\hline \multirow{2}{*}{$\begin{array}{c}\text { Number of } \\
\text { Stories, } N\end{array}$} & \multirow{2}{*}{$\begin{array}{c}T \\
(\mathrm{sec})\end{array}$} & $\gamma$ & \multicolumn{3}{|c|}{$S_{d}=\frac{N \Delta u}{\gamma}$} \\
\cline { 3 - 6 } & & & $\begin{array}{c}\text { Observable } \\
\text { Damage }\end{array}$ & $\begin{array}{r}\text { Yield } \\
\text { Capacity }\end{array}$ & $\begin{array}{r}\text { Ultimate } \\
\text { Capacity }\end{array}$ \\
\hline 1 & 0.1 & 1.0 & 0.25 & 1.0 & 5.0 \\
2 & 0.2 & 1.2 & 0.42 & 1.67 & 8.3 \\
3 & 0.3 & 1.29 & 0.58 & 2.33 & 11.6 \\
4 & 0.4 & 1.33 & 0.75 & 3.01 & 15.0 \\
5 & 0.5 & 1.36 & 0.92 & 3.68 & 18.4 \\
10 & 1.0 & 1.43 & 1.75 & 6.99 & 35.0 \\
20 & 2.0 & 1.46 & 3.42 & 13.70 & 68.5 \\
30 & 3.0 & 1.48 & 5.06 & 20.27 & 101.4 \\
40 & 4.0 & $\approx 1.5$ & 6.67 & 26.67 & 133.3 \\
\hline
\end{tabular}




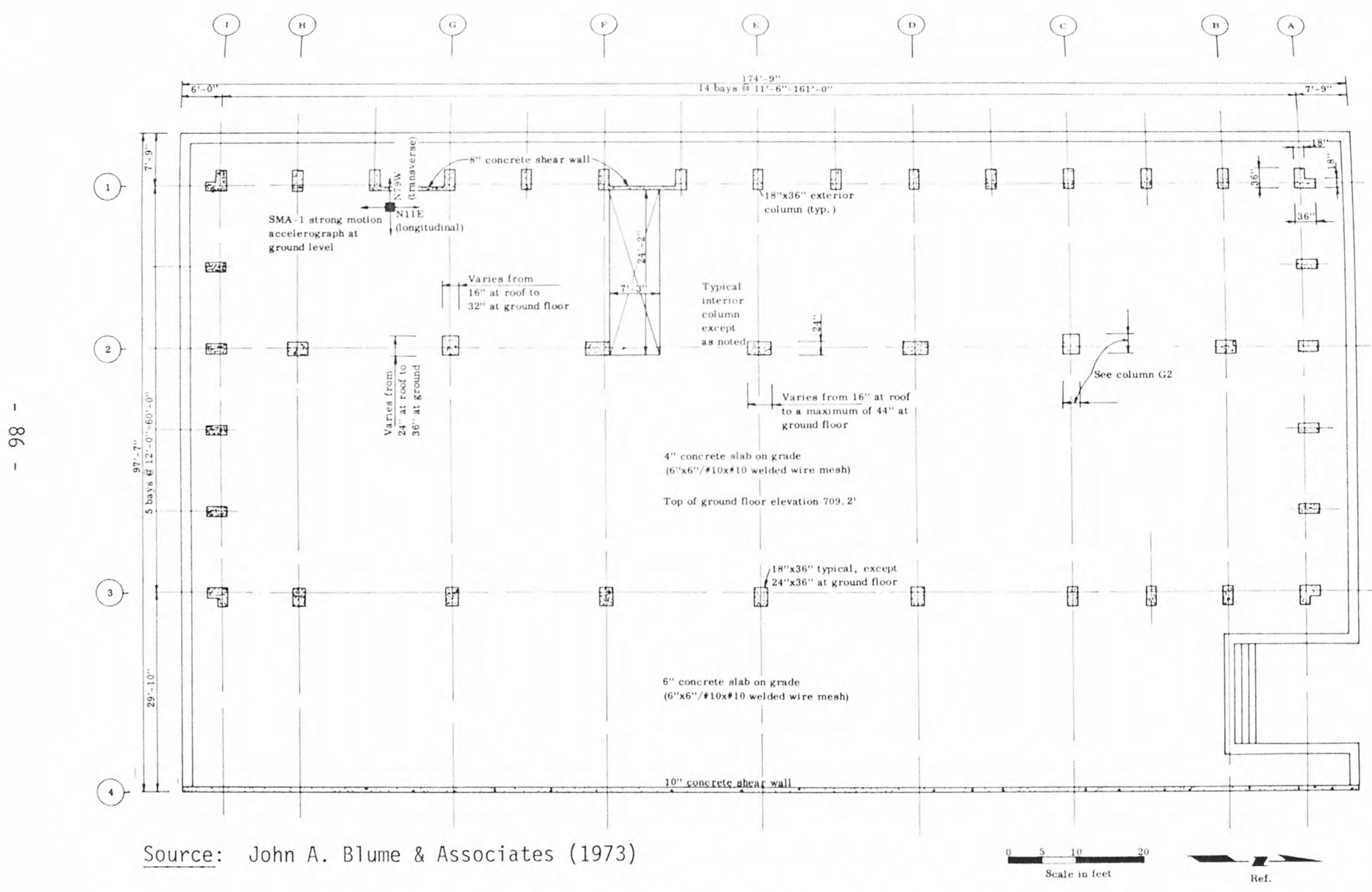

FIGURE 5.1 BANK OF CALIFORNIA BUILDING: GROUND-FLOOR PLAN 


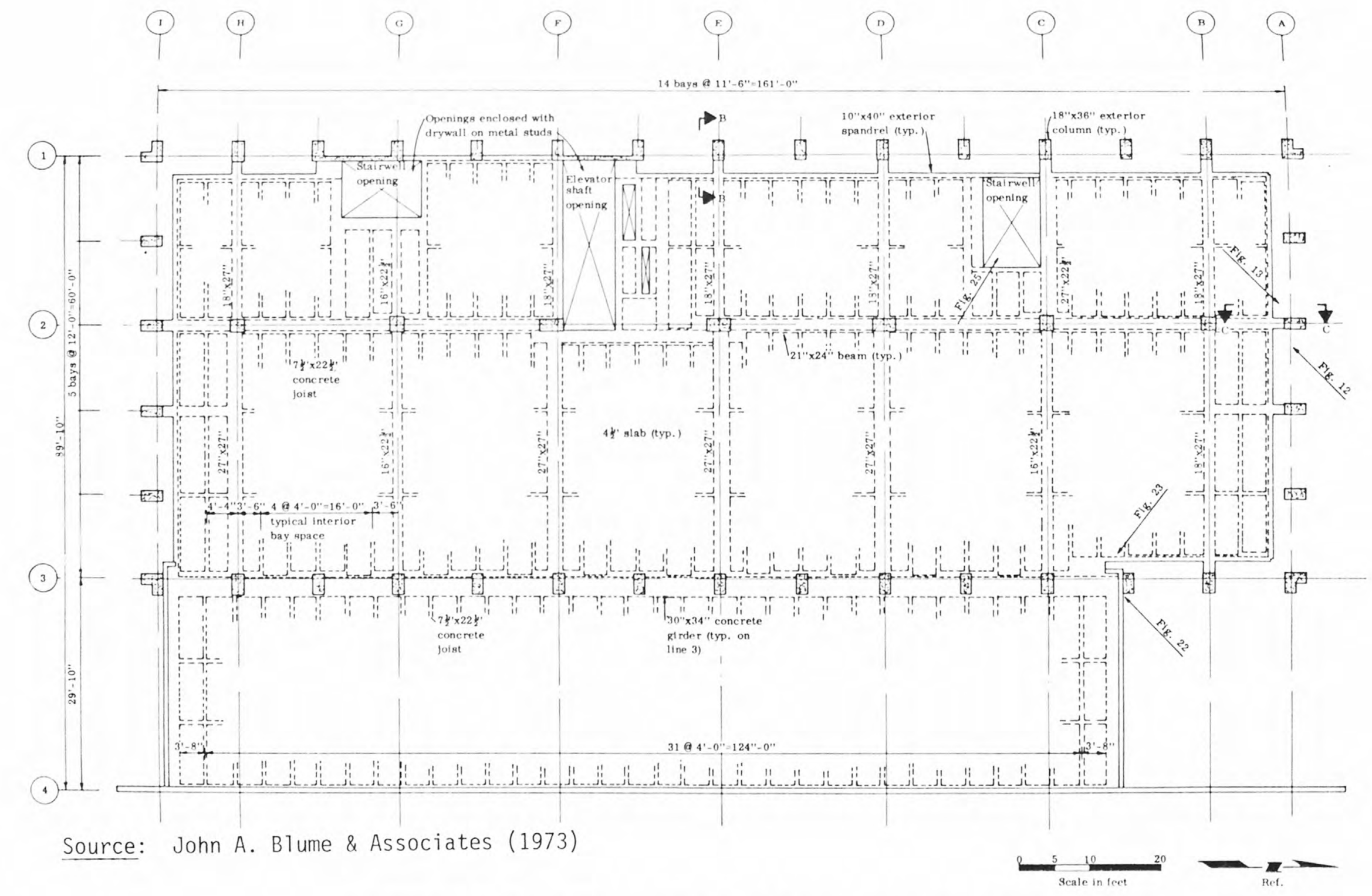

FIGURE 5.2 BANK OF CALIFORNIA BUILDING: SECOND-FLOOR PLAN 


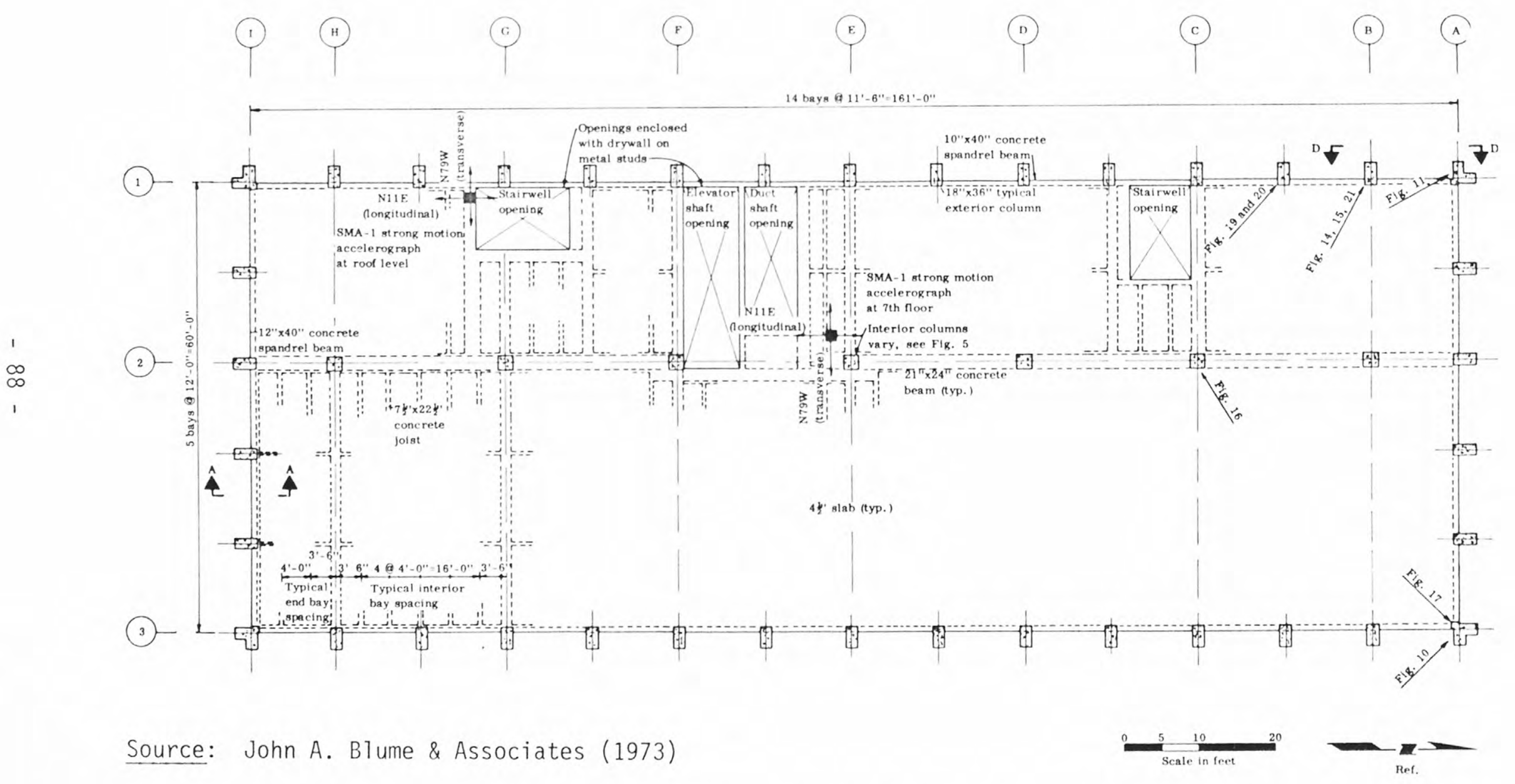

FIGURE 5.3 BANK OF CALIFORNIA BUILDING: TYPICAL FLOOR PLAN, THIRD THROUGH TWELFTH FLOORS 

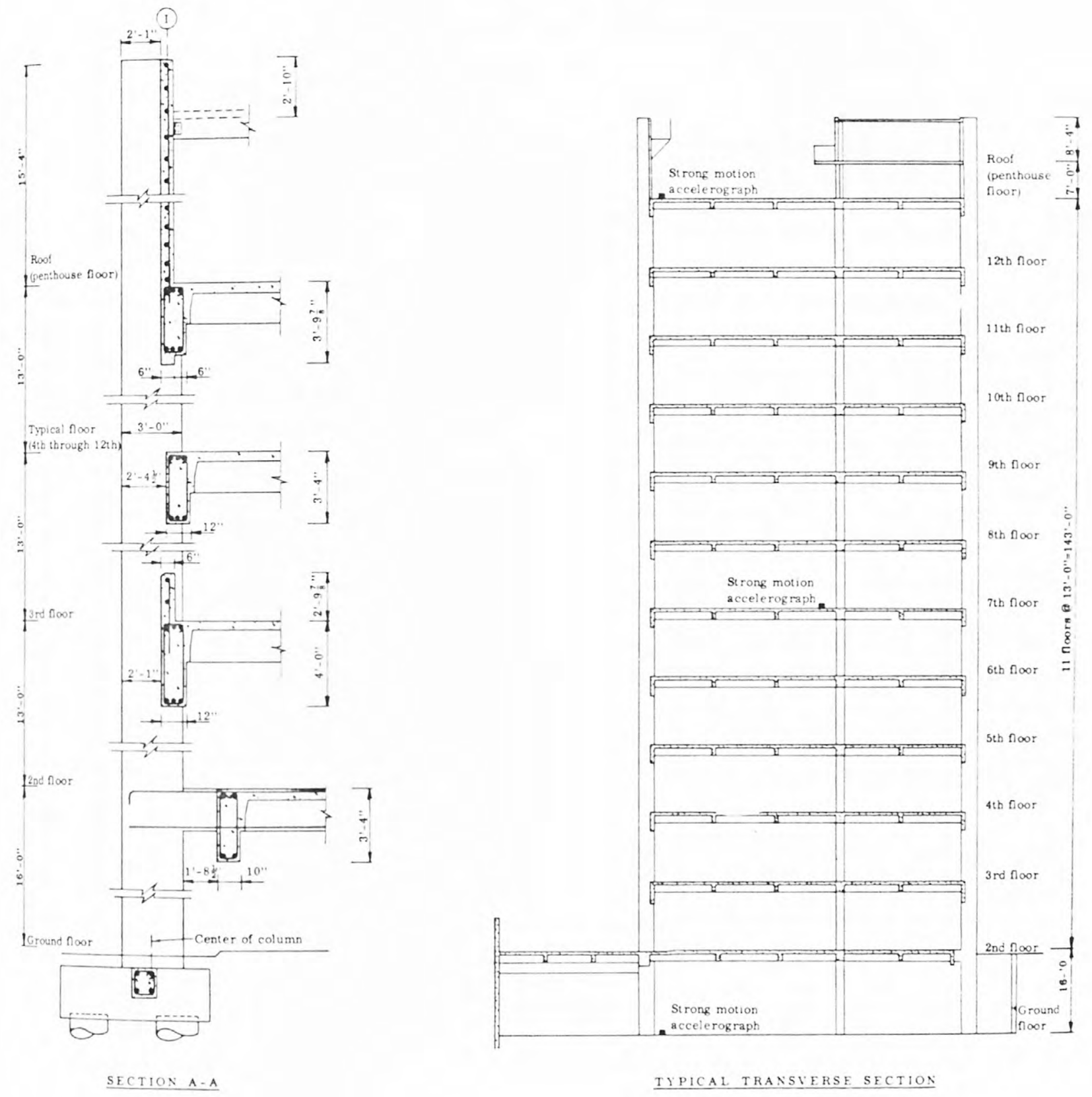

Source: John A. Blume \& Associates (1973)

FIGURE 5.4 BANK OF CALIFORNIA BUILDING: TYPICAL TRANSVERSE SECTION AND STRUCTURAL DETAILS 


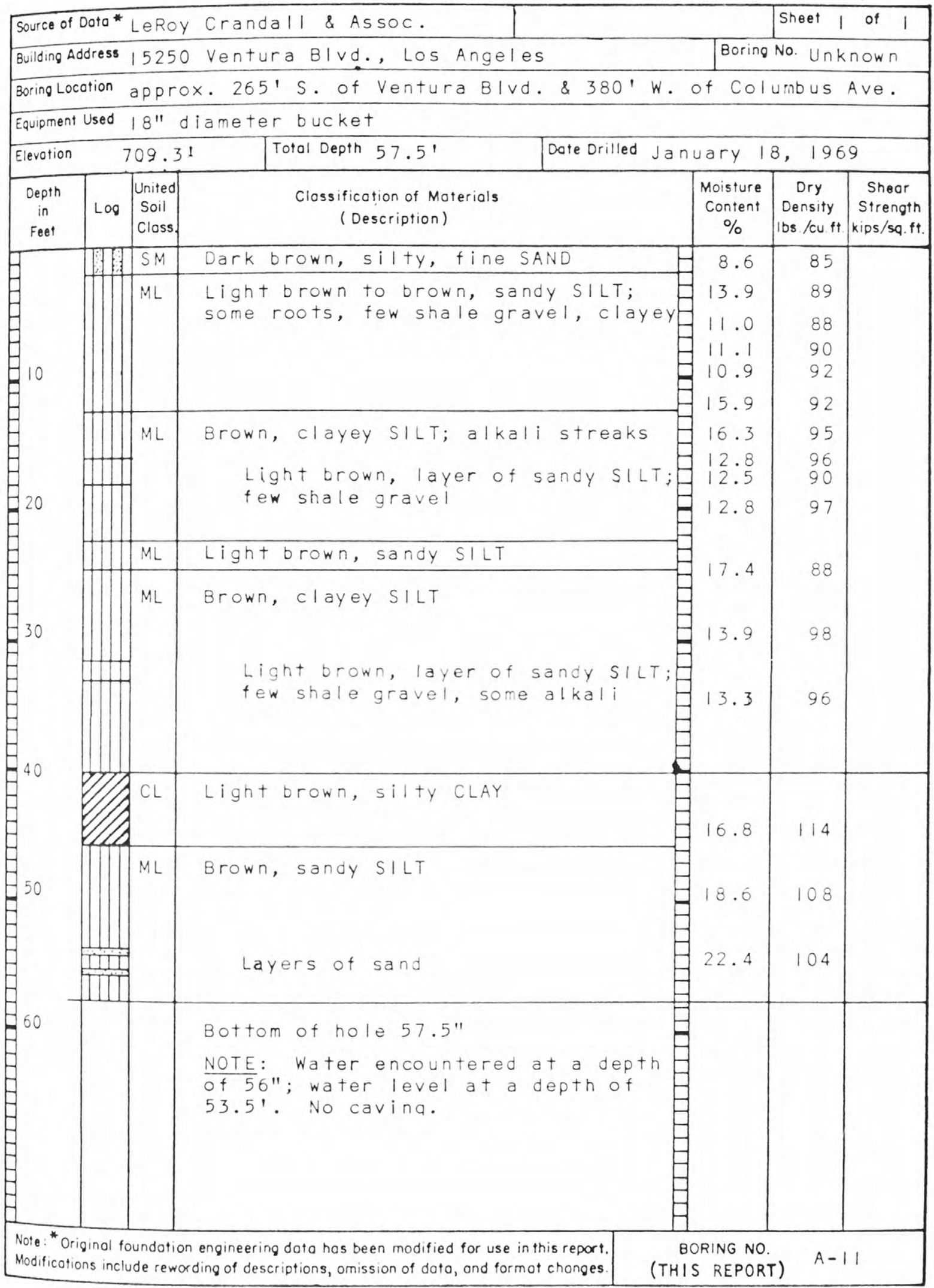

Source: Shannon \& Wilson (1978)

FIGURE 5.5 TYPICAL SOIL BORING LOG AT THE SITE OF THE BANK OF CALIFORNIA BUILDING 


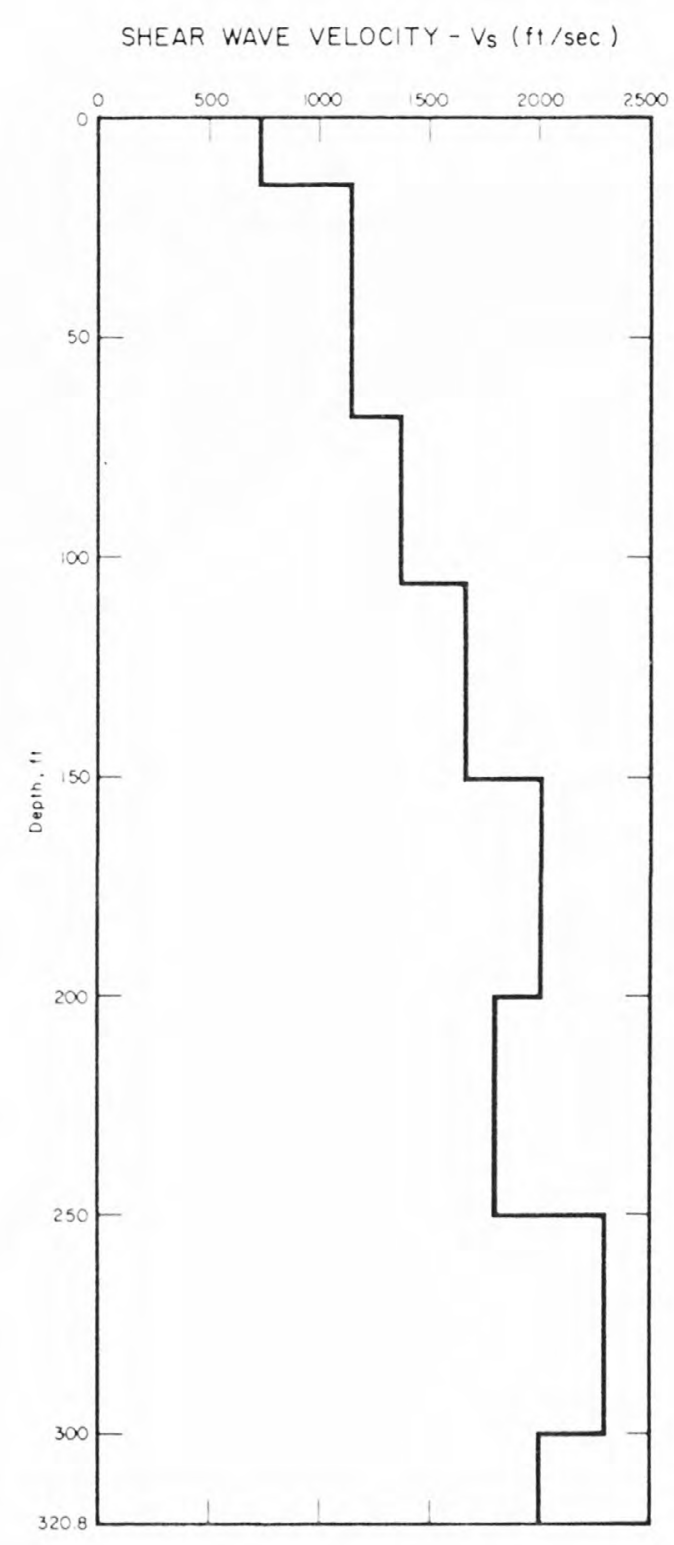

Source: Shannon \& Wilson (1978)

FIGURE 5.6 SHEAR WAVE VELOCITY AT THE SITE OF THE BANK OF CALIFORNIA BUILDING 

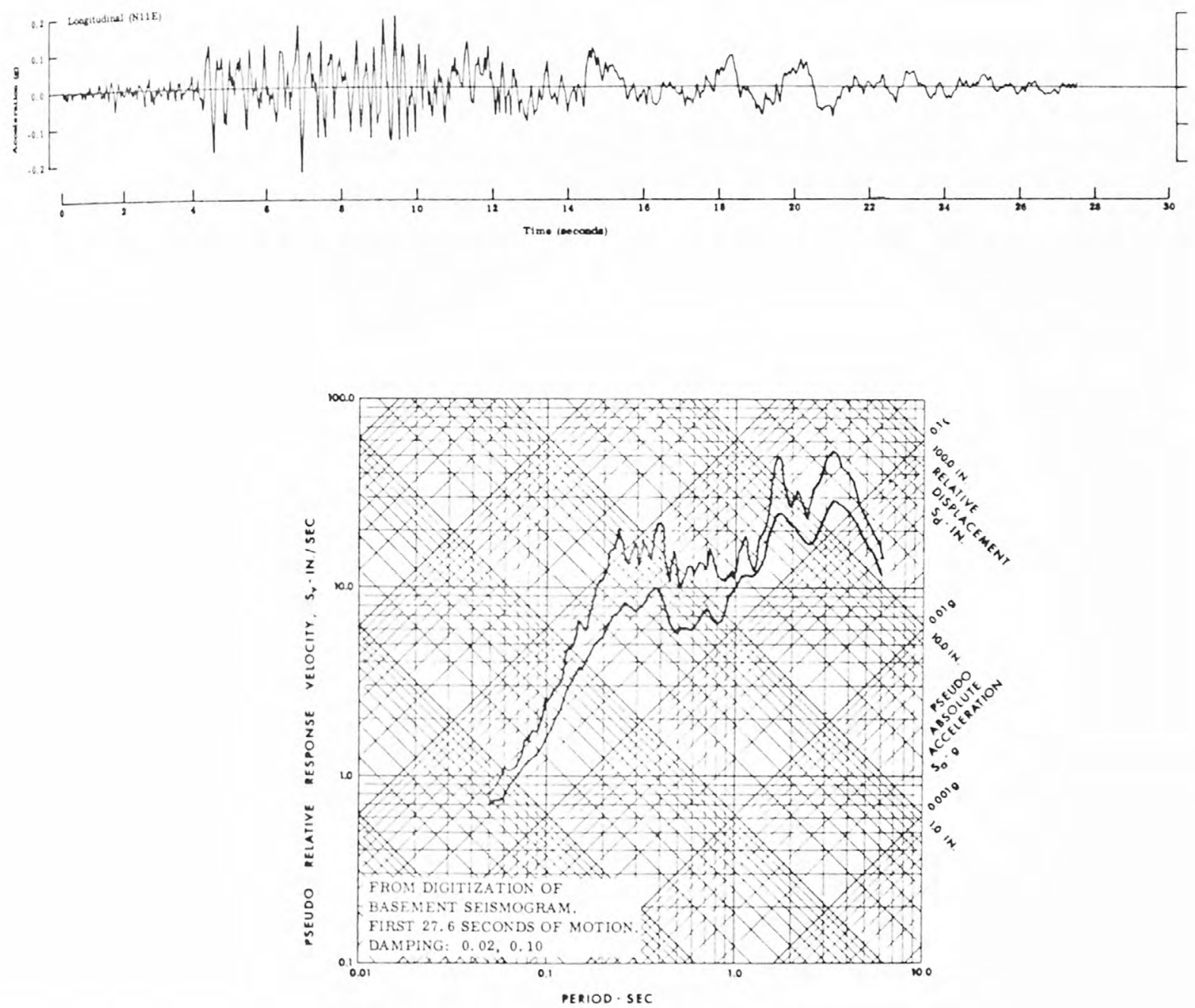

Source: John A. BTume \& Associates (1973)

FIGURE 5.7 BANK OF CALIFORNIA BUILDING, GROUND FLOOR: RECORDED LONGITUDINAL ACCELERATION TIME HISTORY AND ASSOCIATED RESPONSE SPECTRA 

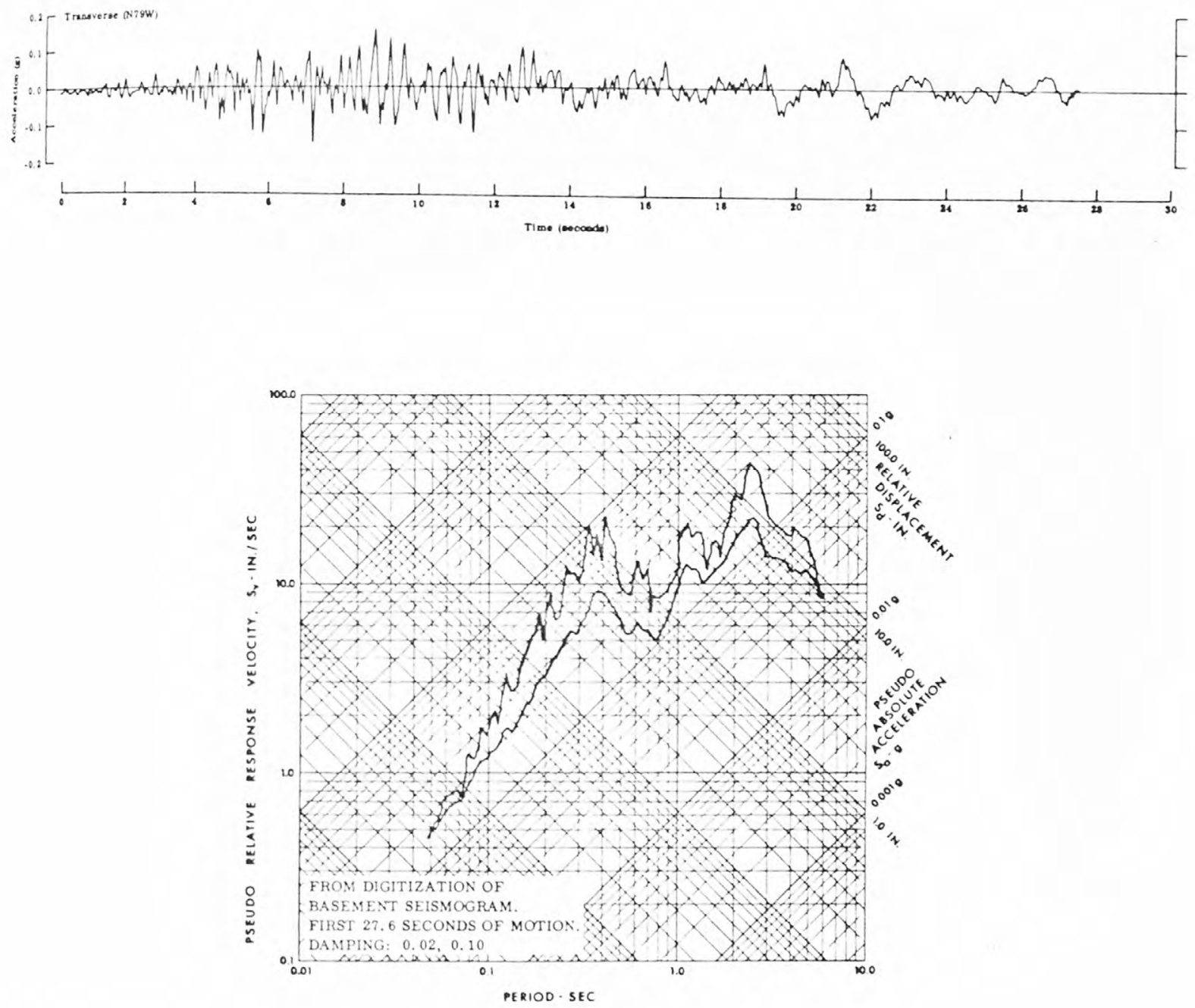

Source: John A. B7ume \& Associates (1973)

FIGURE 5.8 BANK OF CALIFORNIA BUILDING, GROUND FLOOR: RECORDED TRANSVERSE ACCELERATION TIME HISTORY AND ASSOCIATED RESPONSE SPECTRA 

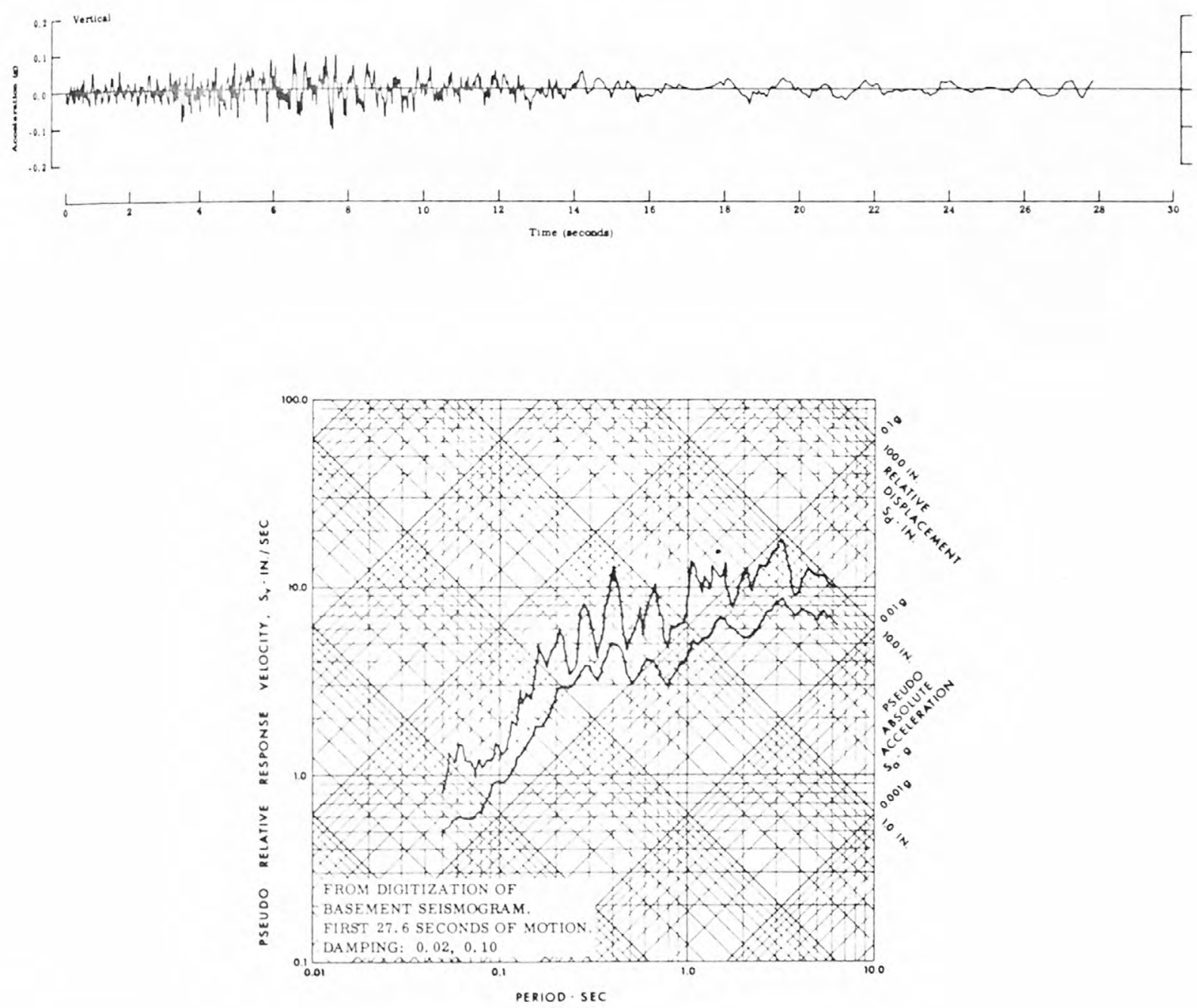

Source: John A. Blume \& Associates (1973)

FIGURE 5.9 BANK OF CALIFORNIA BUILDING, GROUND FLOOR: RECORDED VERTICAL ACCELERATION TIME HISTORY AND ASSOCIATED RESPONSE SPECTRA 
Time (sec)

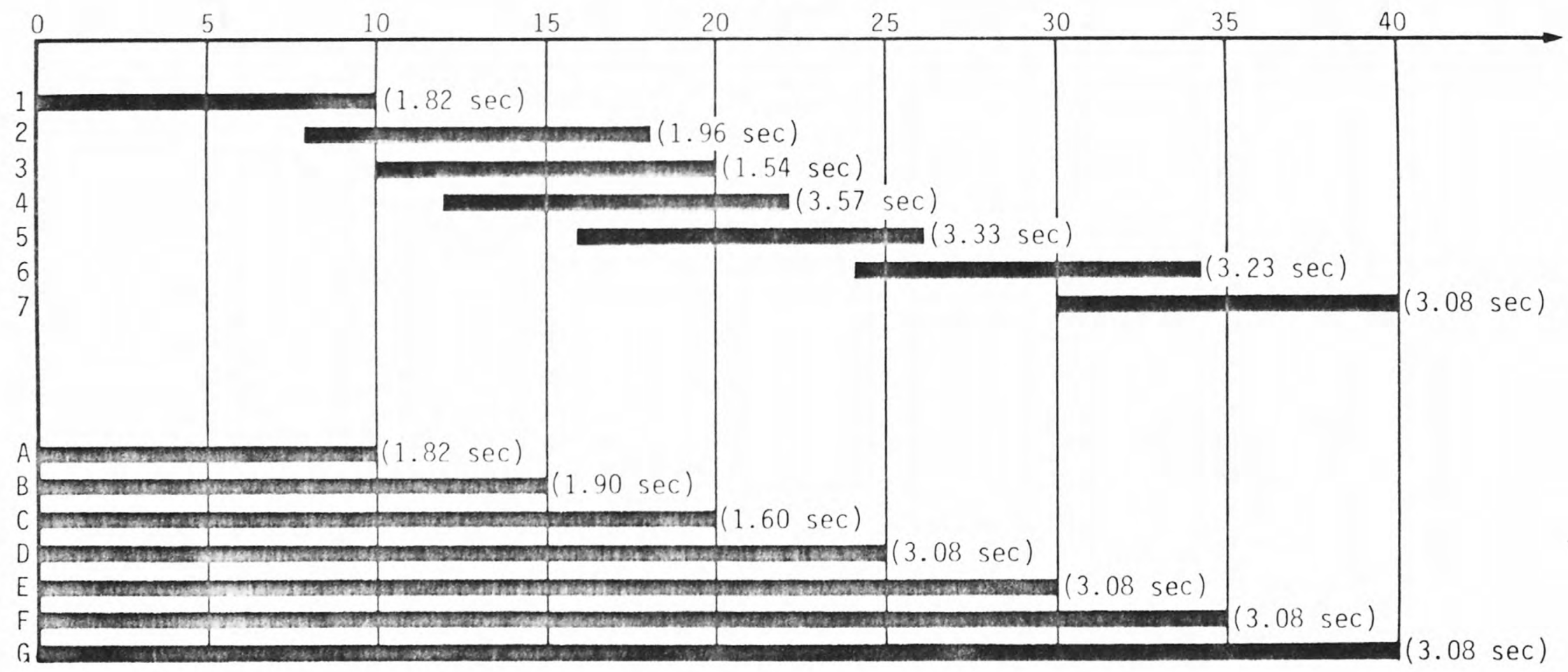

Note: Fundamental periods are shown in parentheses. Instantaneous transfer functions for cases 1 through 7 and A through $G$ are given in Figure 5.12 .

FIGURE 5.10 BANK OF CALIFORNIA BUILDING: FUNDAMENTAL PERIODS OBTAINED FROM INSTANTANEOUS TRANSFER FUNCTIONS 


\section{7th Floor, Transverse Direction}

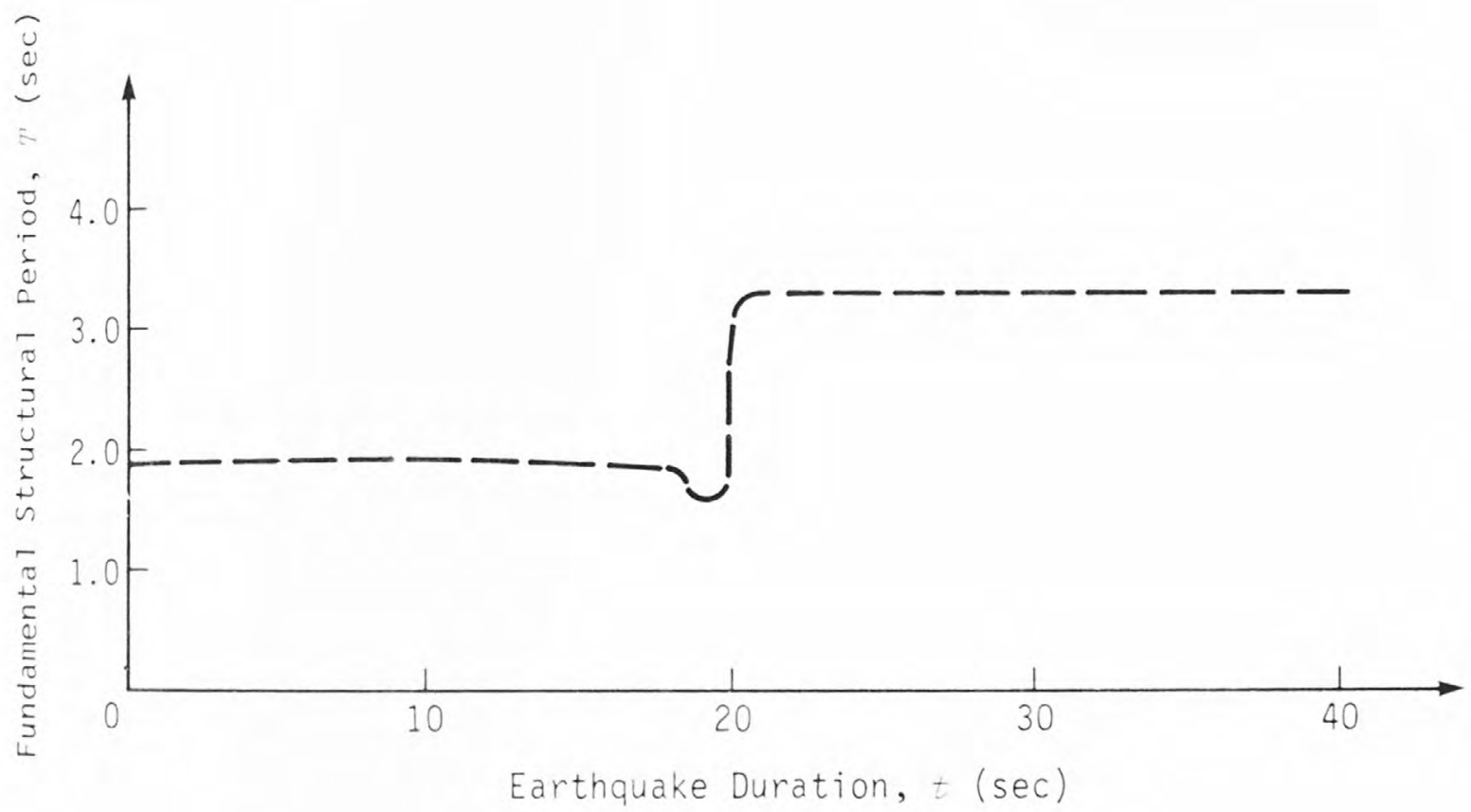

FIGURE 5.11 BANK OF CALIFORNIA BUILDING: CHANGE OF FUNDAMENTAL PERIODS DURING EARTHQUAKE EXCITATION 


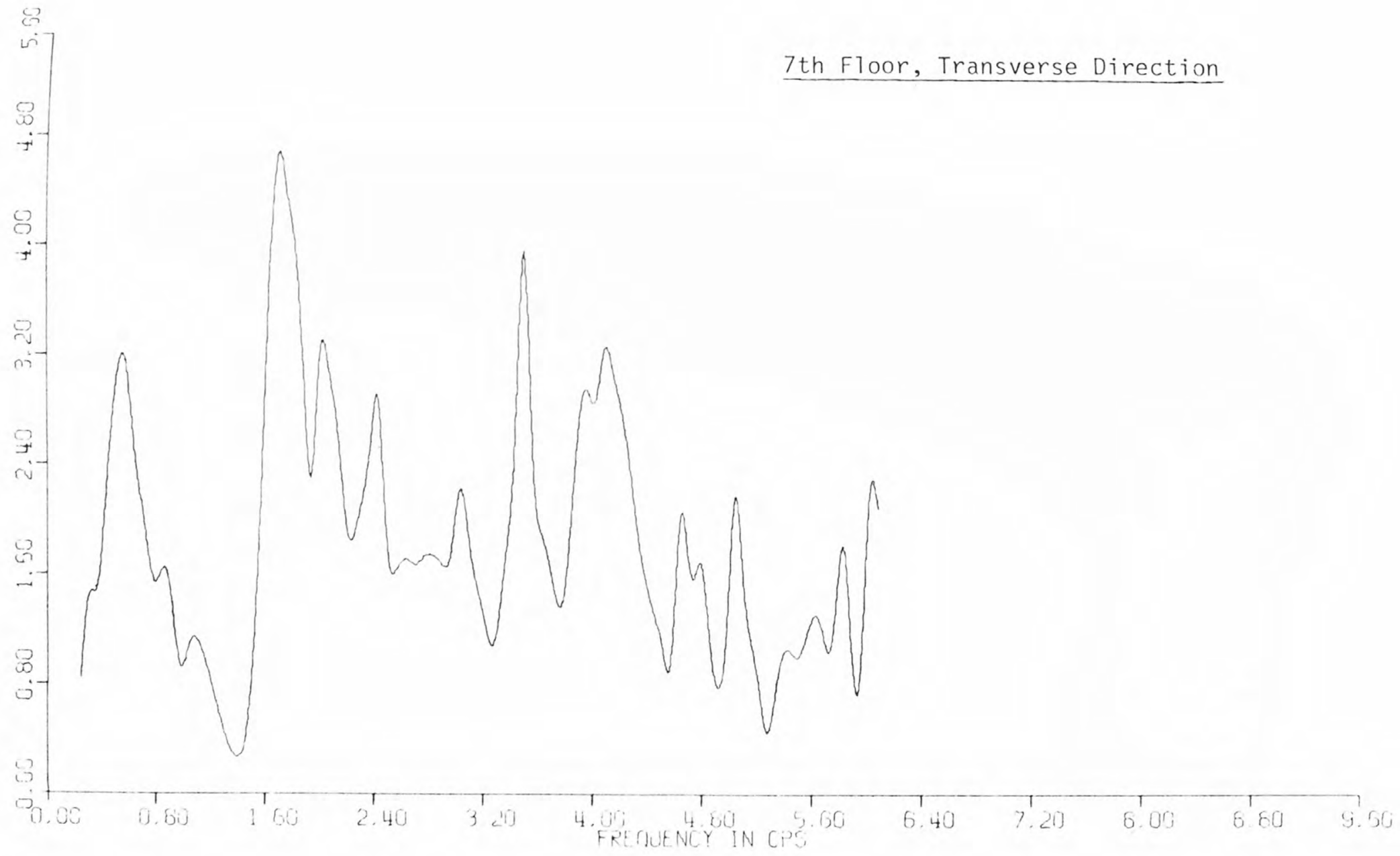

FIGURE 5.12a BANK OF CALIFORNIA BUILDING: INSTANTANEOUS TRANSFER FUNCTION: CASES 1 and A 


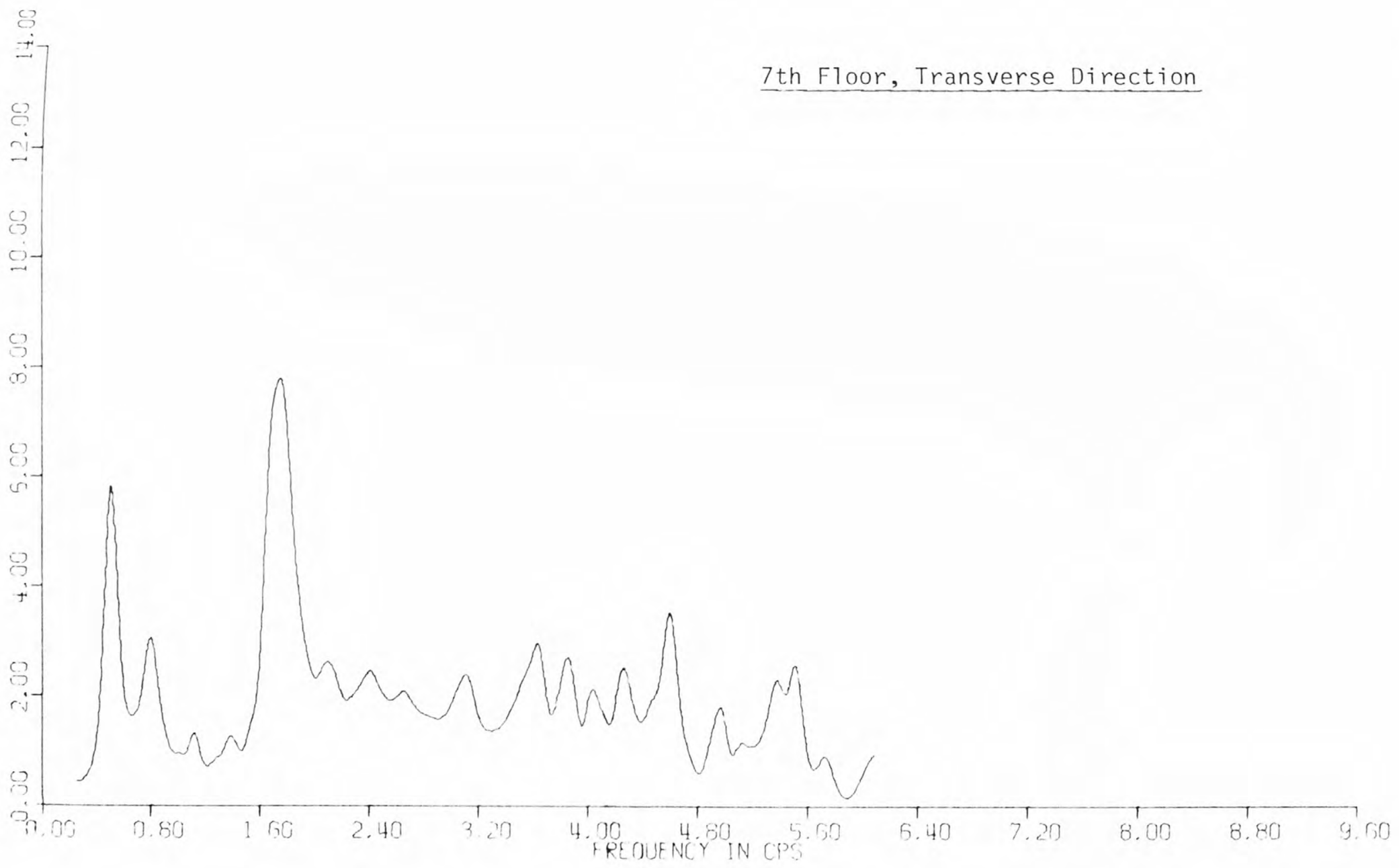

FIGURE 5.12b BANK OF CALIFORNIA BUILDING: INSTANTANEOUS TRANSFER FUNCTION: CASE 2 


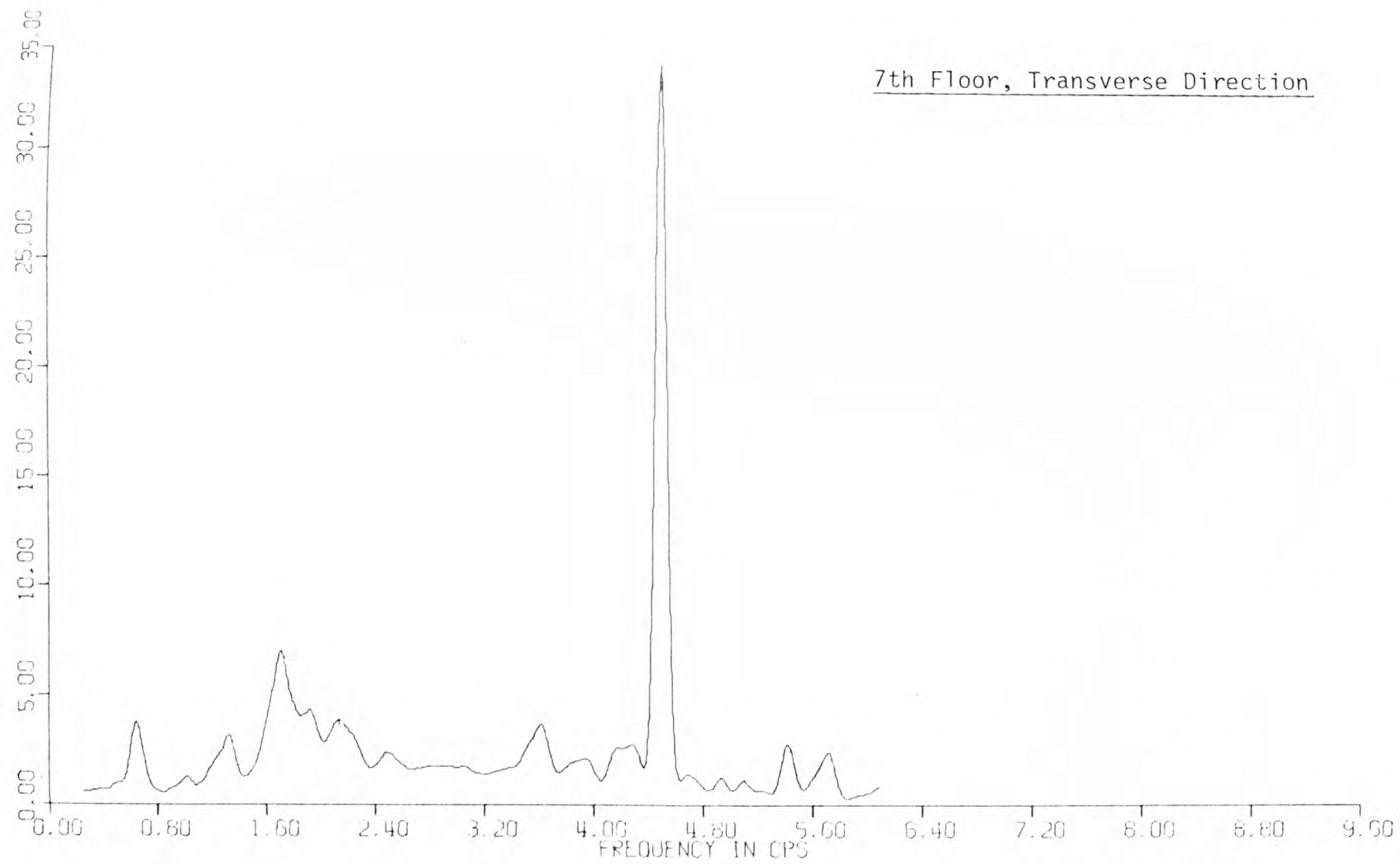

FIGURE 5.12C BANK OF CALIFORNIA BUILDING: INSTANTANEOUS TRANSFER FUNCTION: 


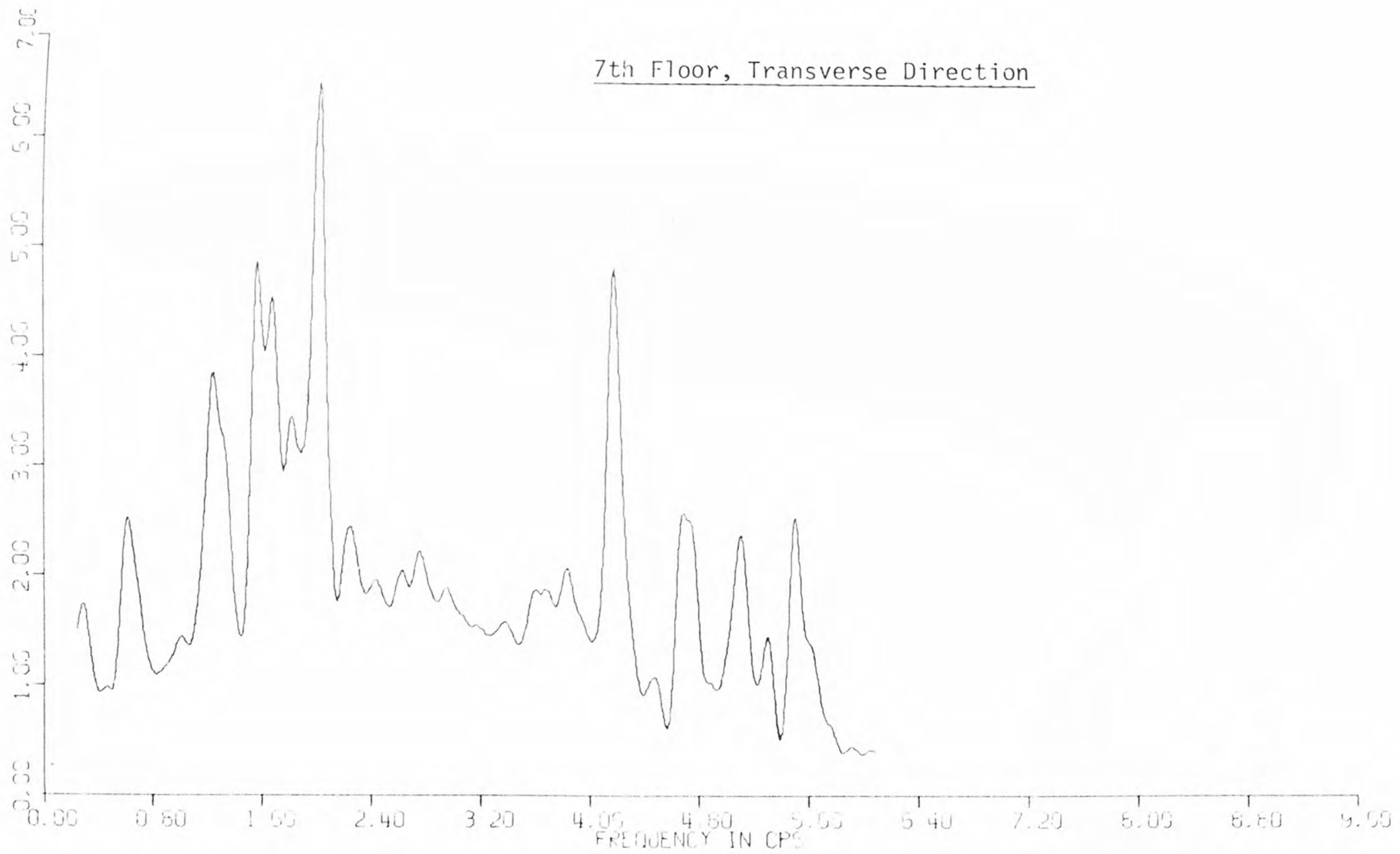

FIGURE 5.12d BANK OF CALIFORNIA BUILDING: INSTANTANEOUS TRANSFER FUNCTION: CASE 4 


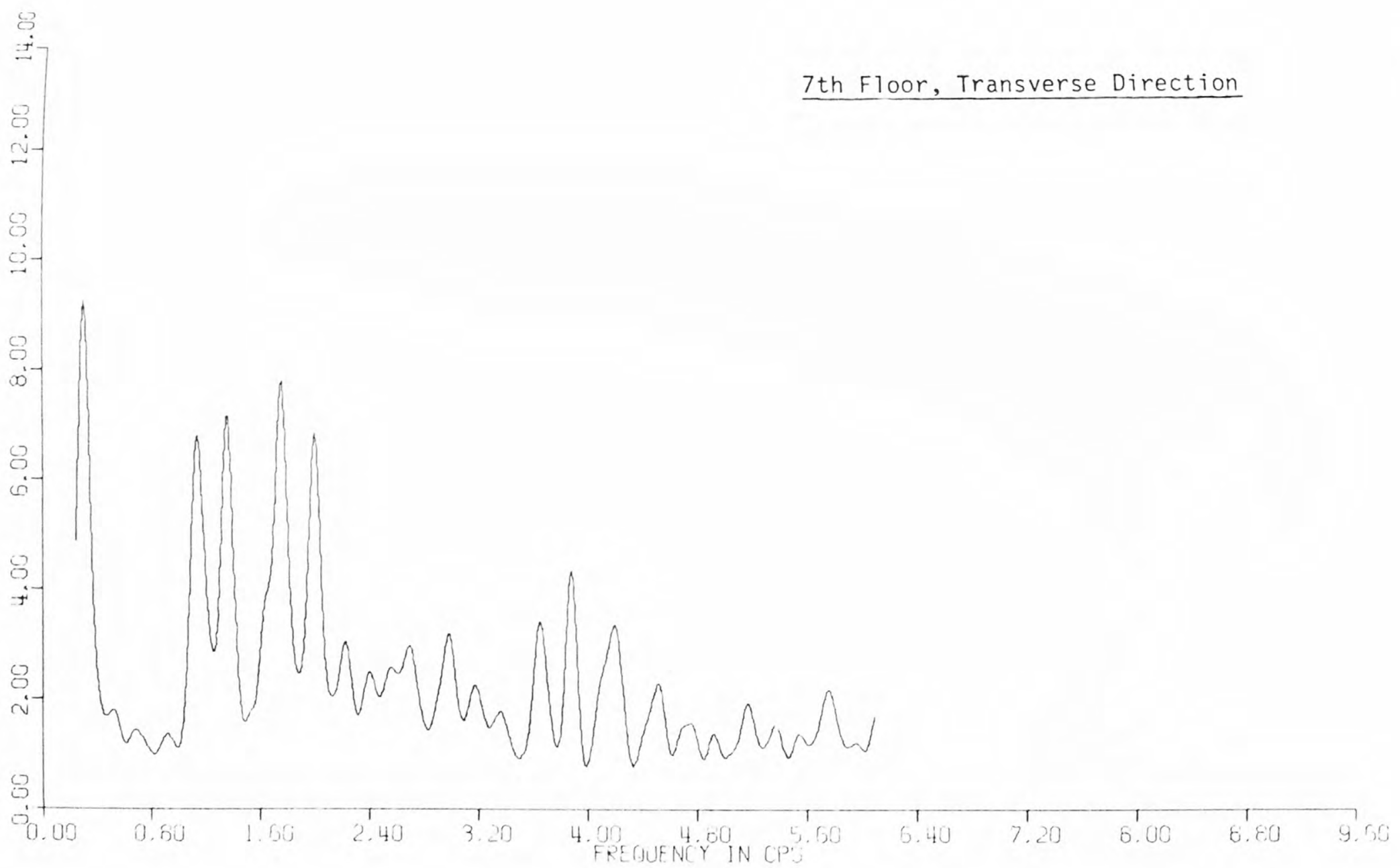

FIGURE 5.12e BANK OF CALIFORNIA BUILDING: INSTANTANEOUS TRANSFER FUNCTION: CASE 5 


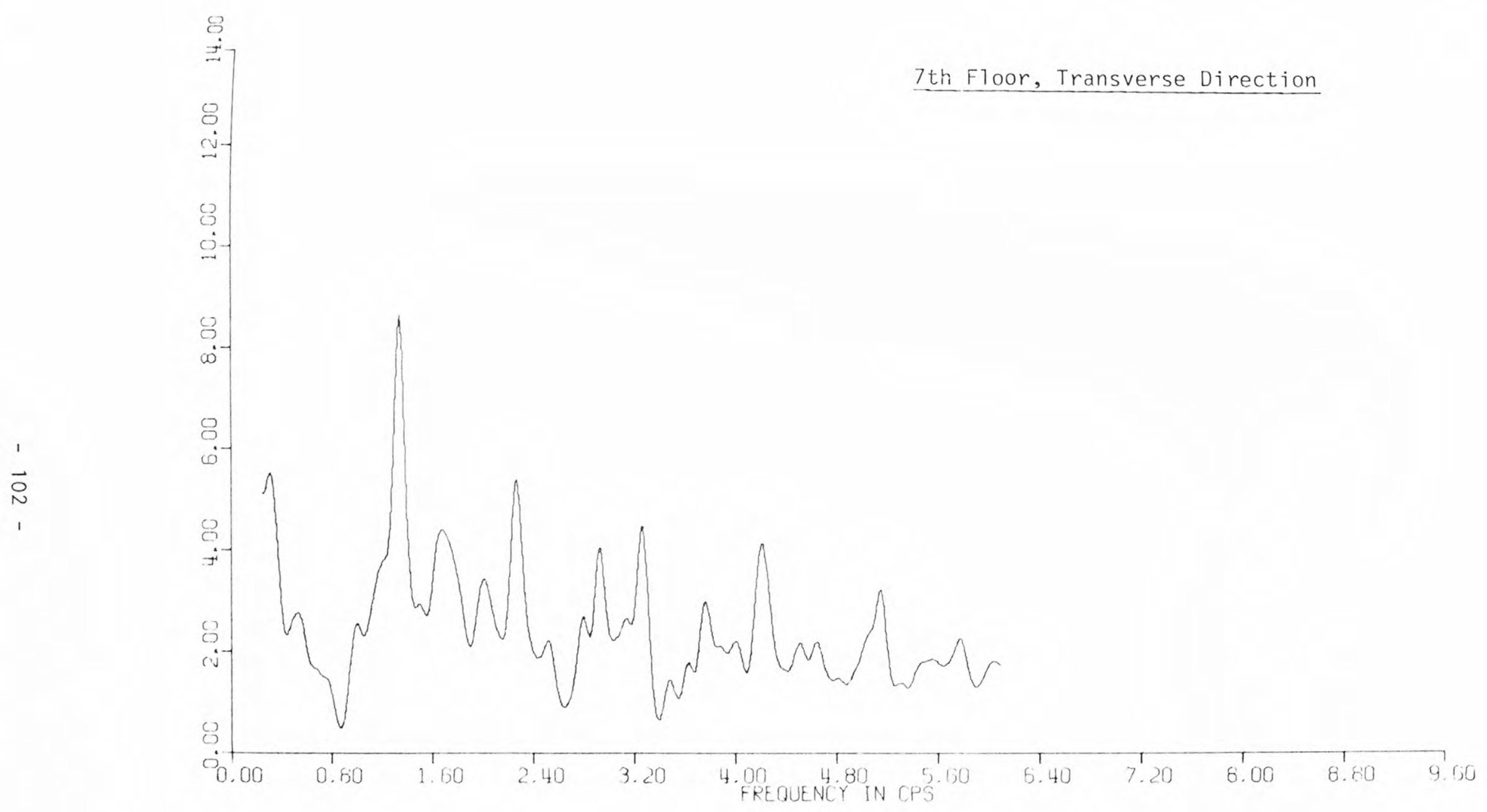

FIGURE 5.12f BANK OF CALIFORNIA BUILDING: INSTANTANEOUS TRANSFER FUNCTION: CASE 6 


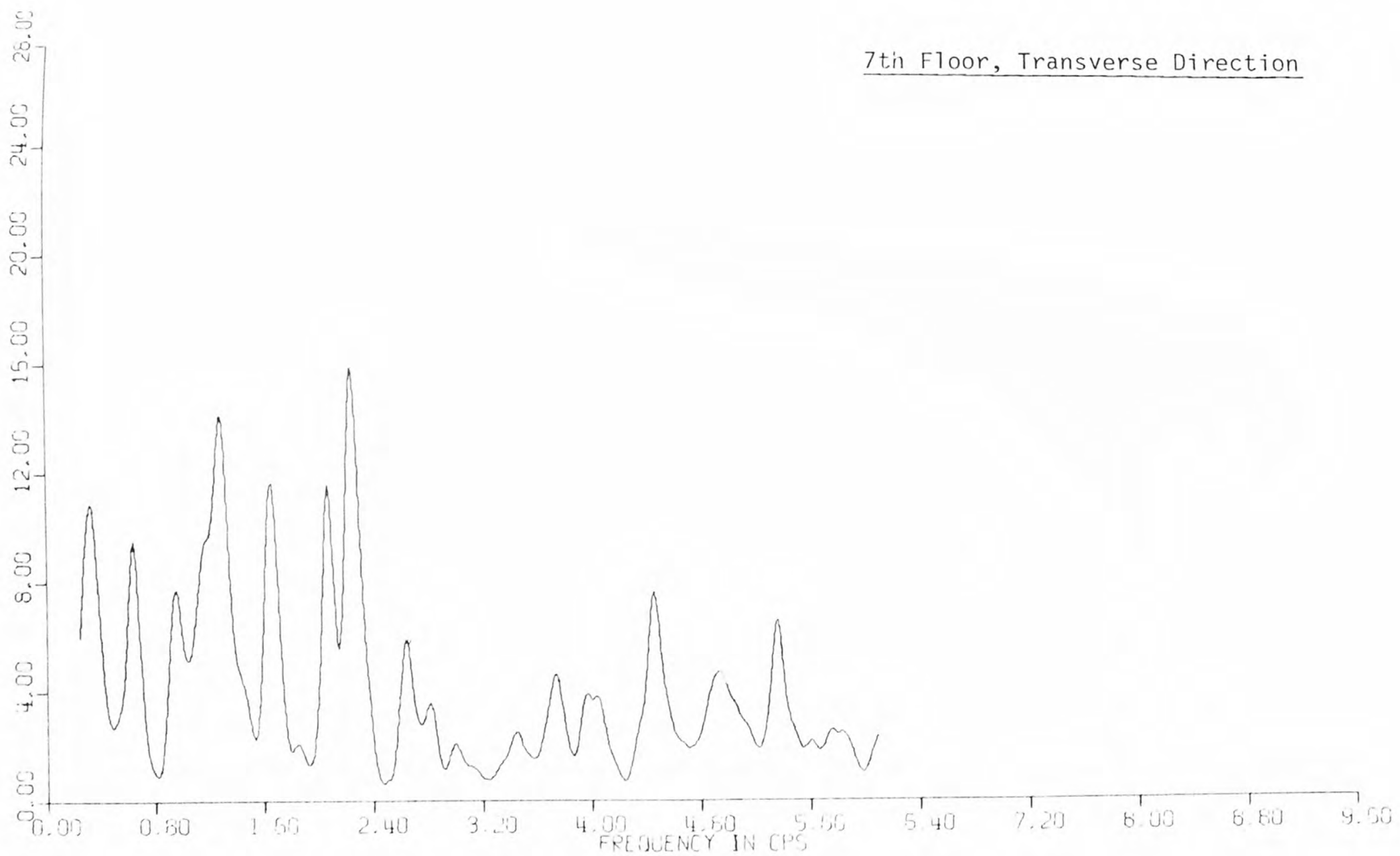

FIGURE $5.12 \mathrm{~g}$ BANK OF CALIFORNIA BUILDING: INSTANTANEOUS TRANSFER FUNCTION: CASE 7 


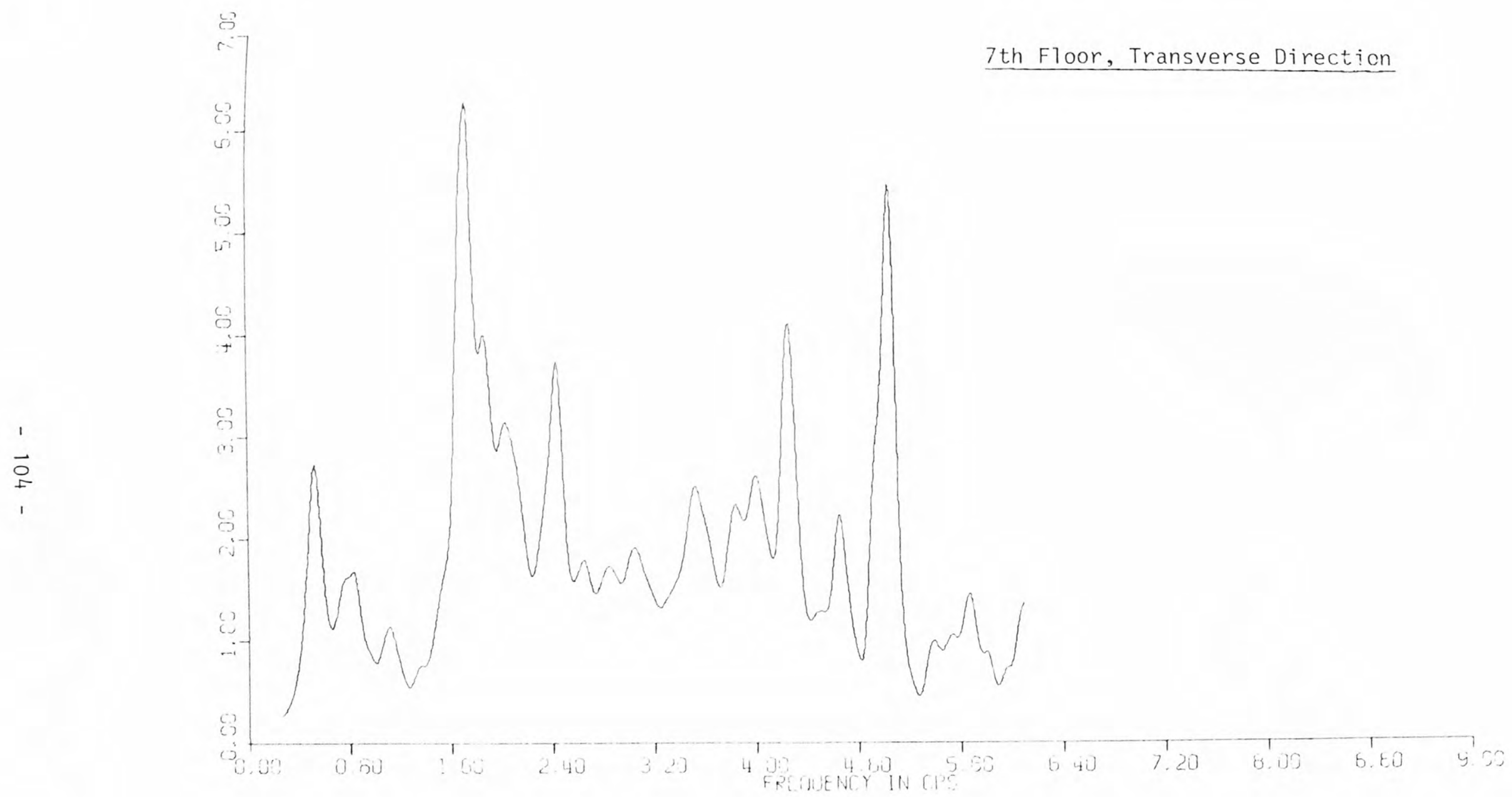

FIGURE 5.12h BANK OF CALIFORNIA BUILDING: INSTANTANEOUS TRANSFER FUNCTION: CASE B 


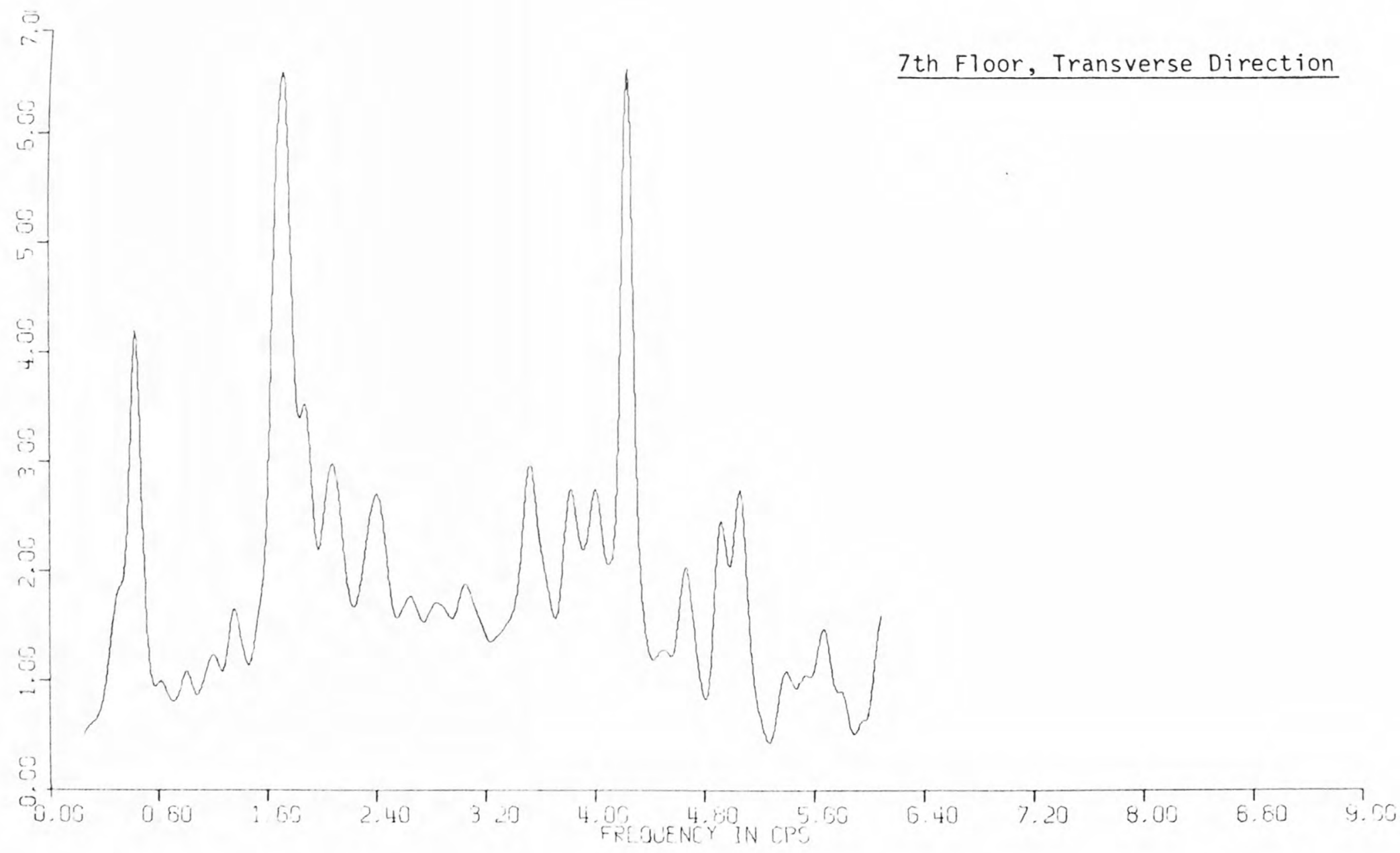

FIGURE $5.12 \mathrm{i}$ BANK OF CALIFORNIA BUILDING: INSTANTANEOUS TRANSFER FUNCTION: CASE C 


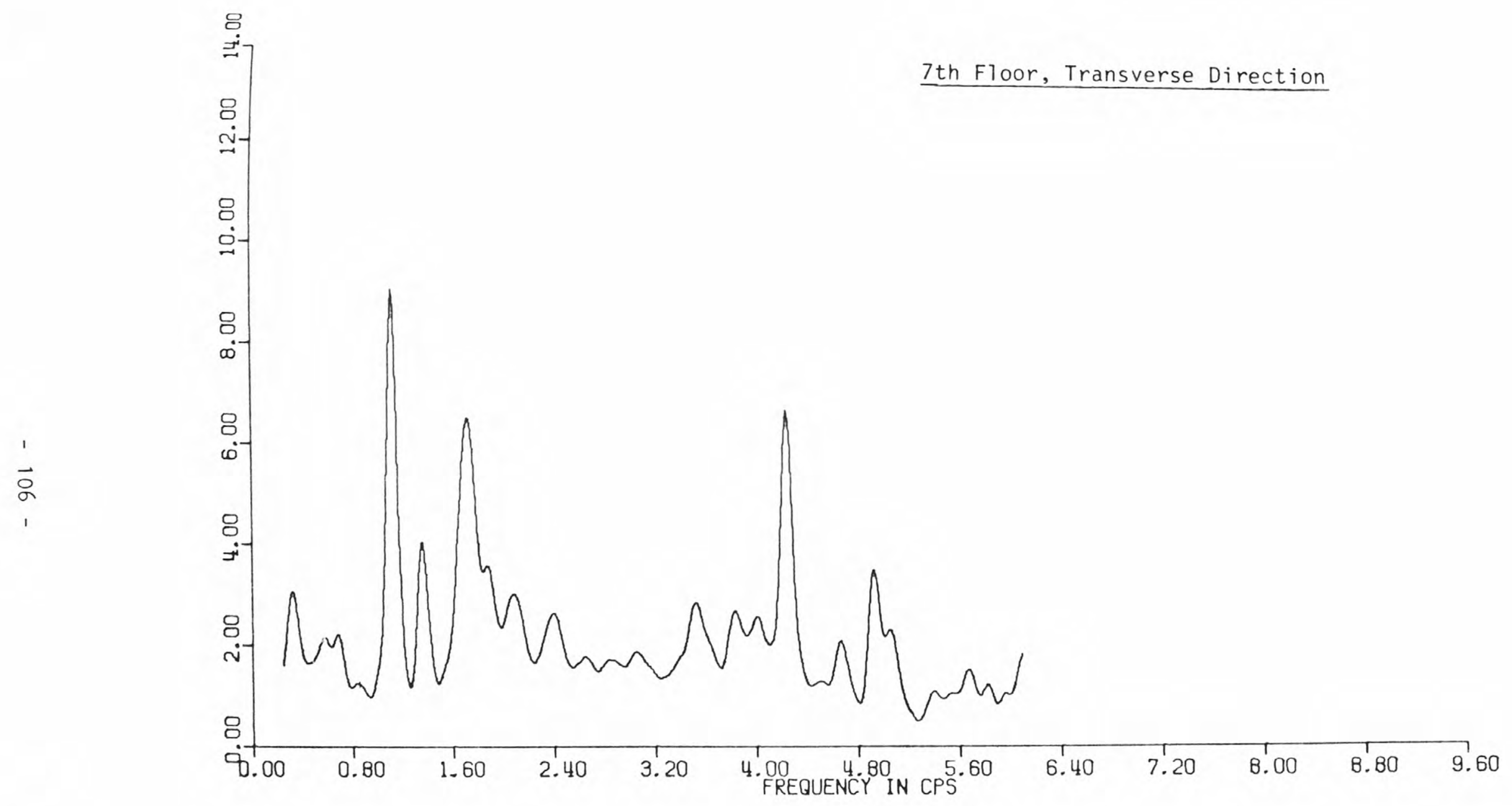

FIGURE $5.12 \mathrm{j}$ BANK OF CALIFORNIA BUILDING: INSTANTANEOUS TRANSFER FUNCTION: CASE D 


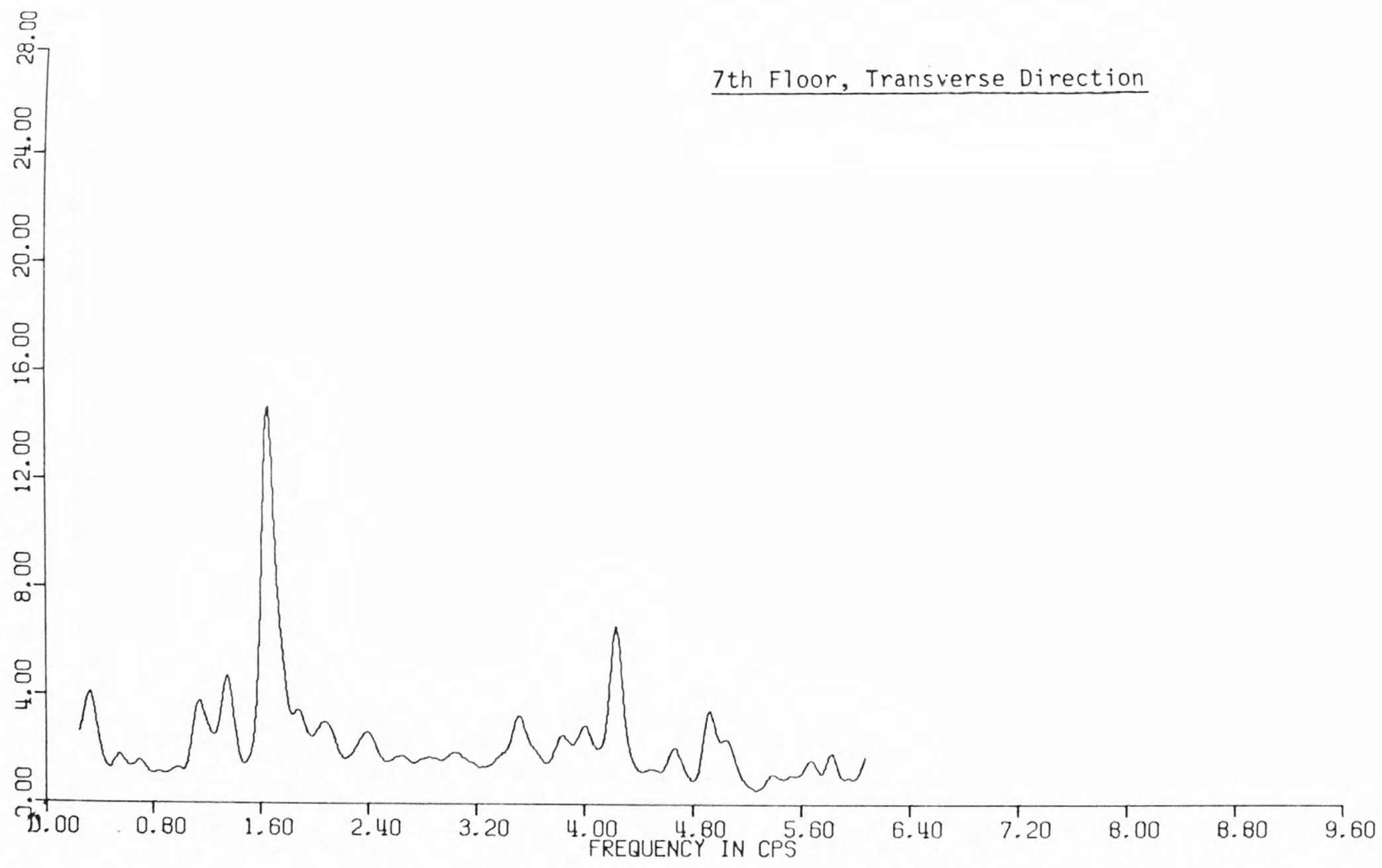

FIGURE 5.12k BANK OF CALIFORNIA BUILDING: INSTANTANEOUS TRANSFER FUNCTION: CASE E 


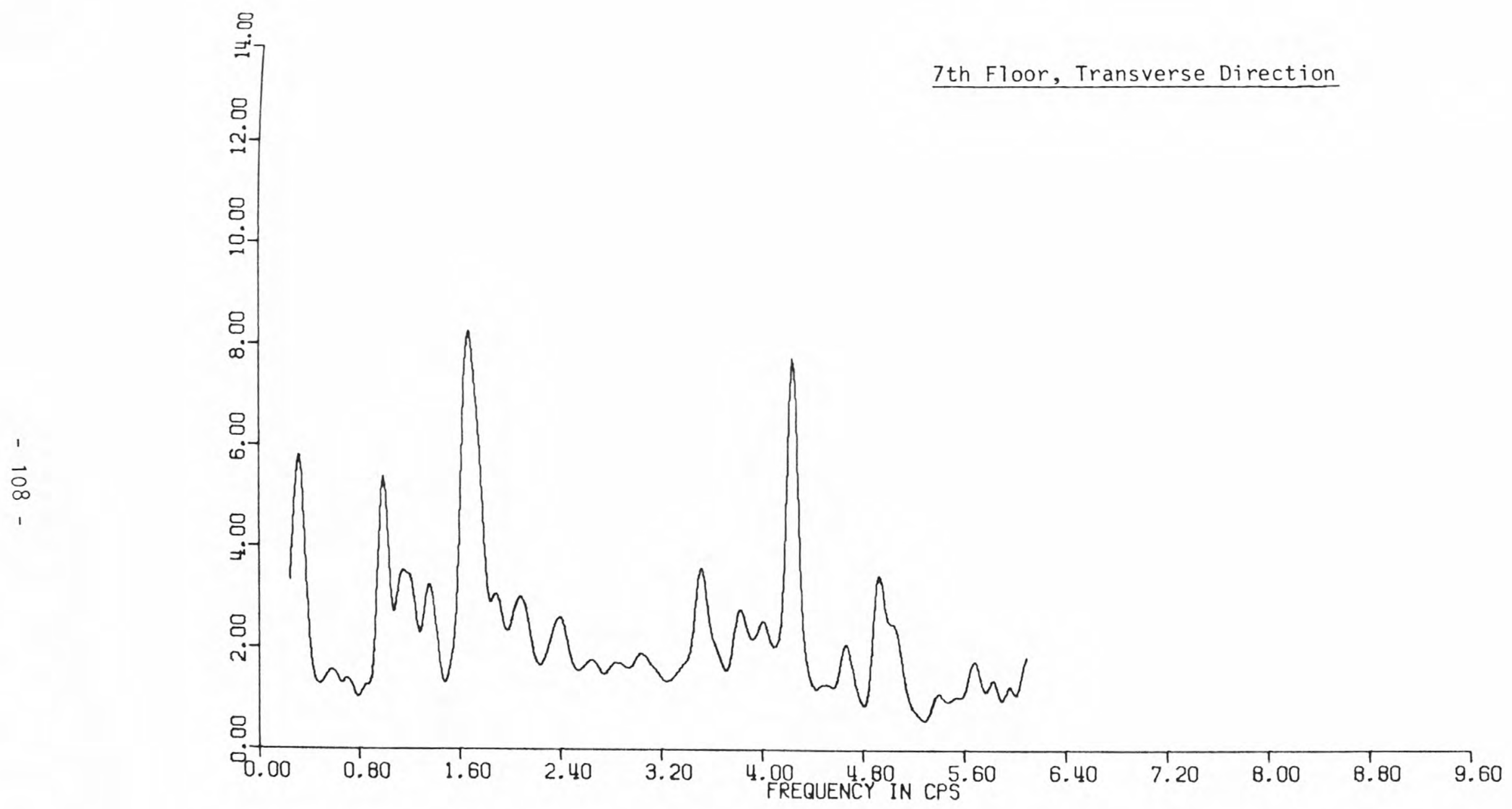

FIGURE 5.121 BANK OF CALIFORNIA BUILDING: INSTANTANEOUS TRANSFER FUNCTION: CASE F 


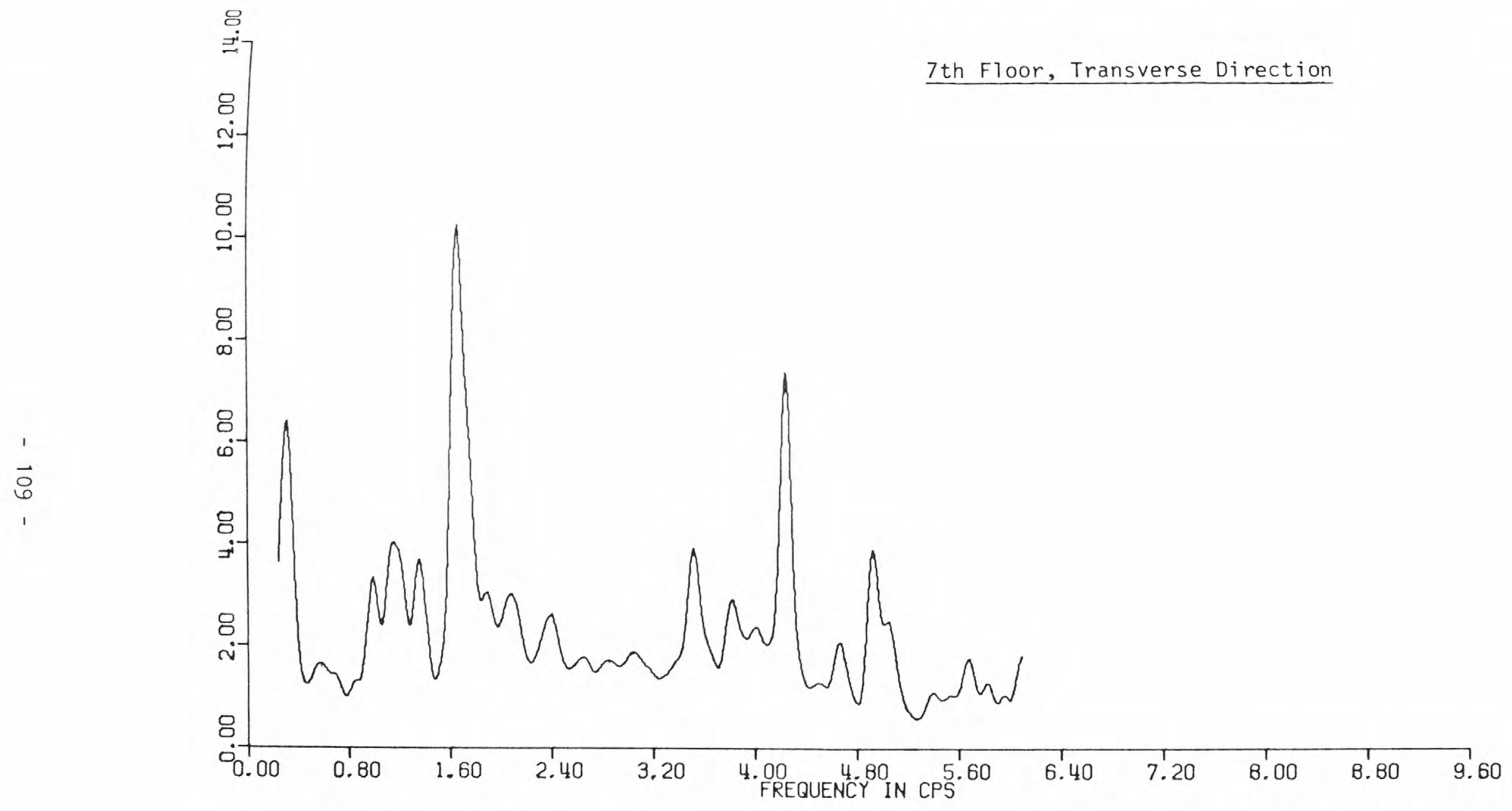

FIGURE 5.12m BANK OF CALIFORNIA BUILDING: INSTANTANEOUS TRANSFER FUNCTION: CASE G 


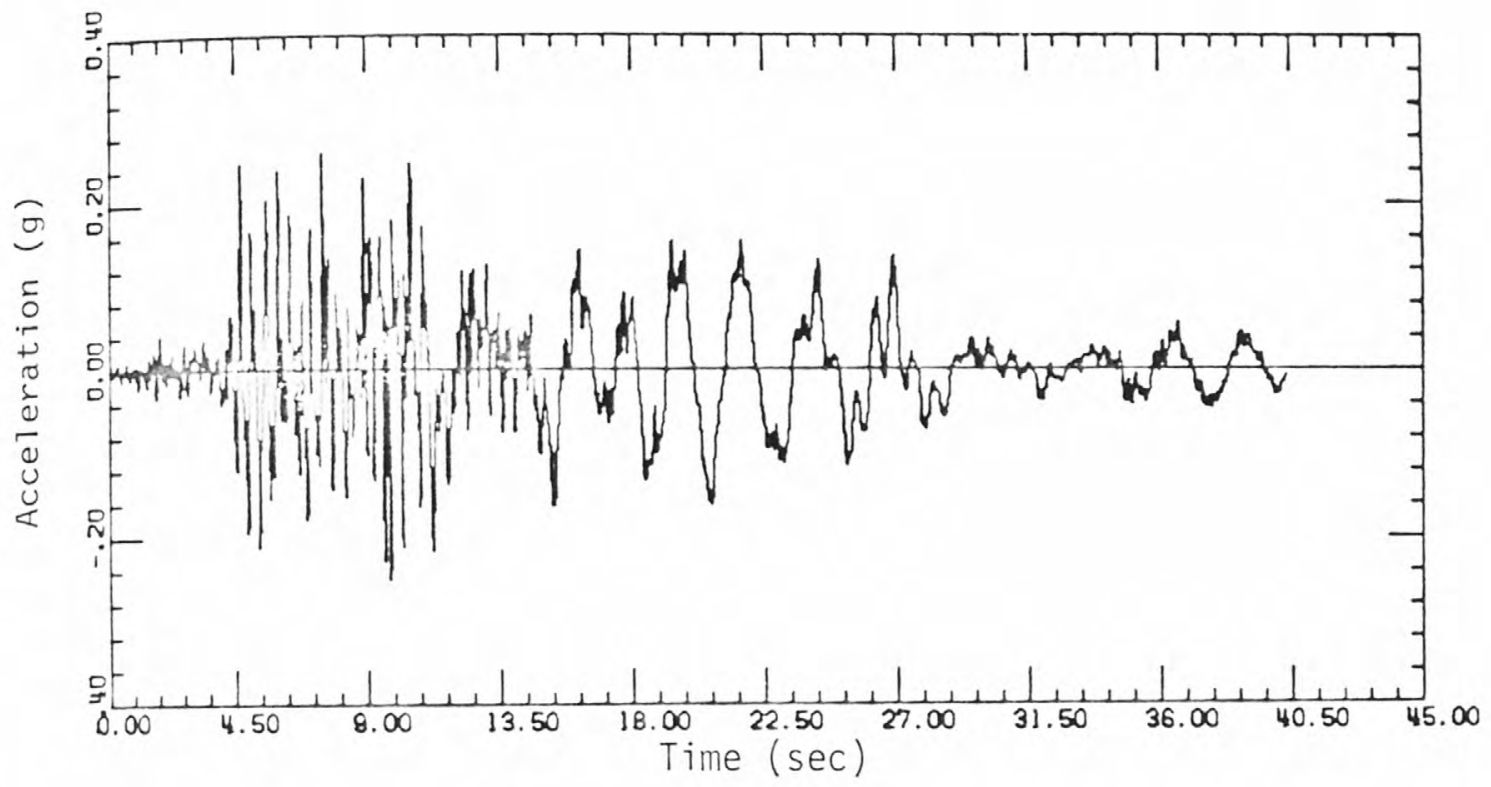

Recorded Time History

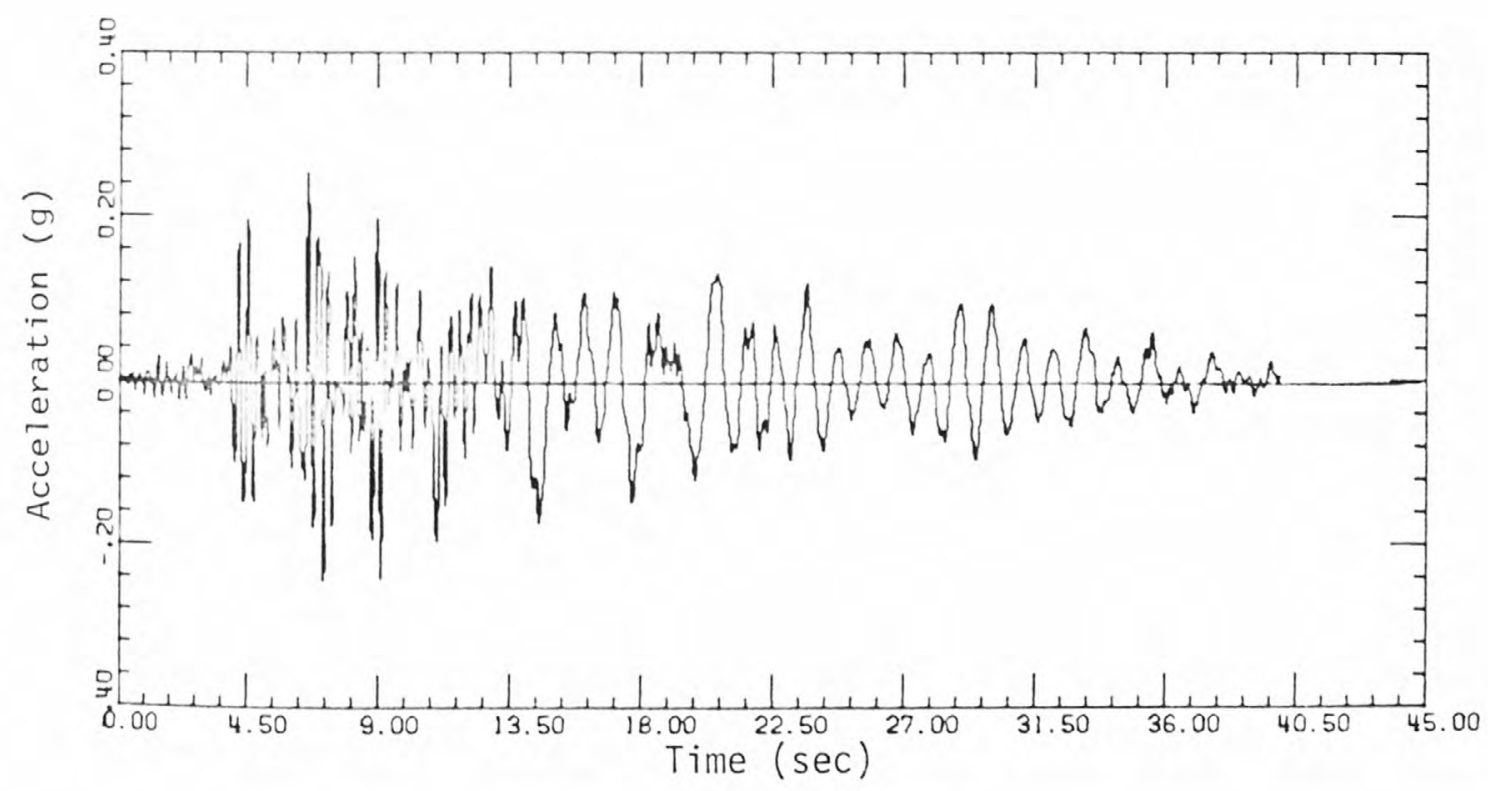

Theoretical Time History

FIGURE 5.13a MODEL 1, RECORDED AND THEORETICAL TIME HISTORIES: BANK OF CALIFORNIA BUILDING, SEVENTH FLOOR, LONGITUDINAL DIRECTION 


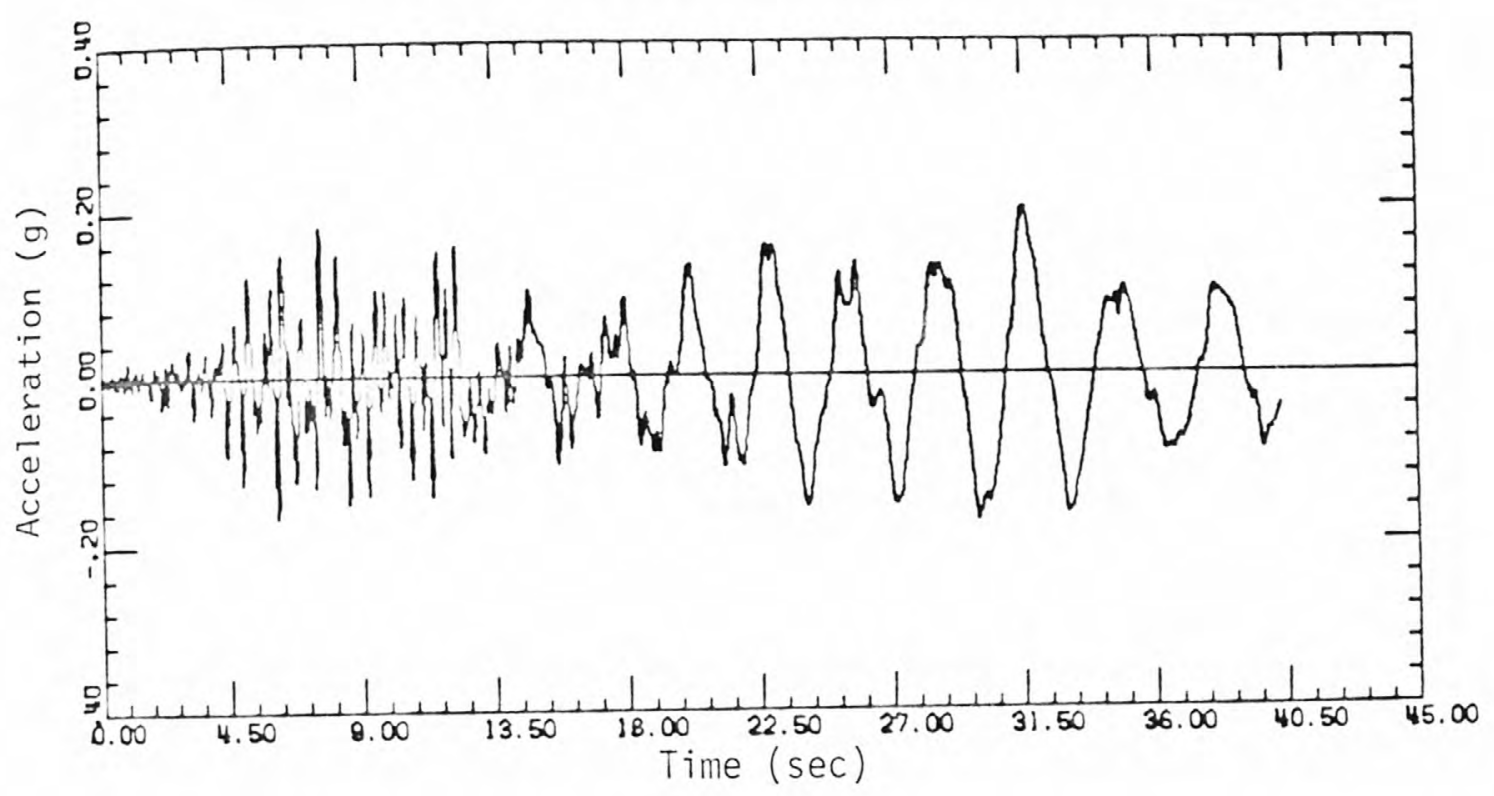

Recorded Time History

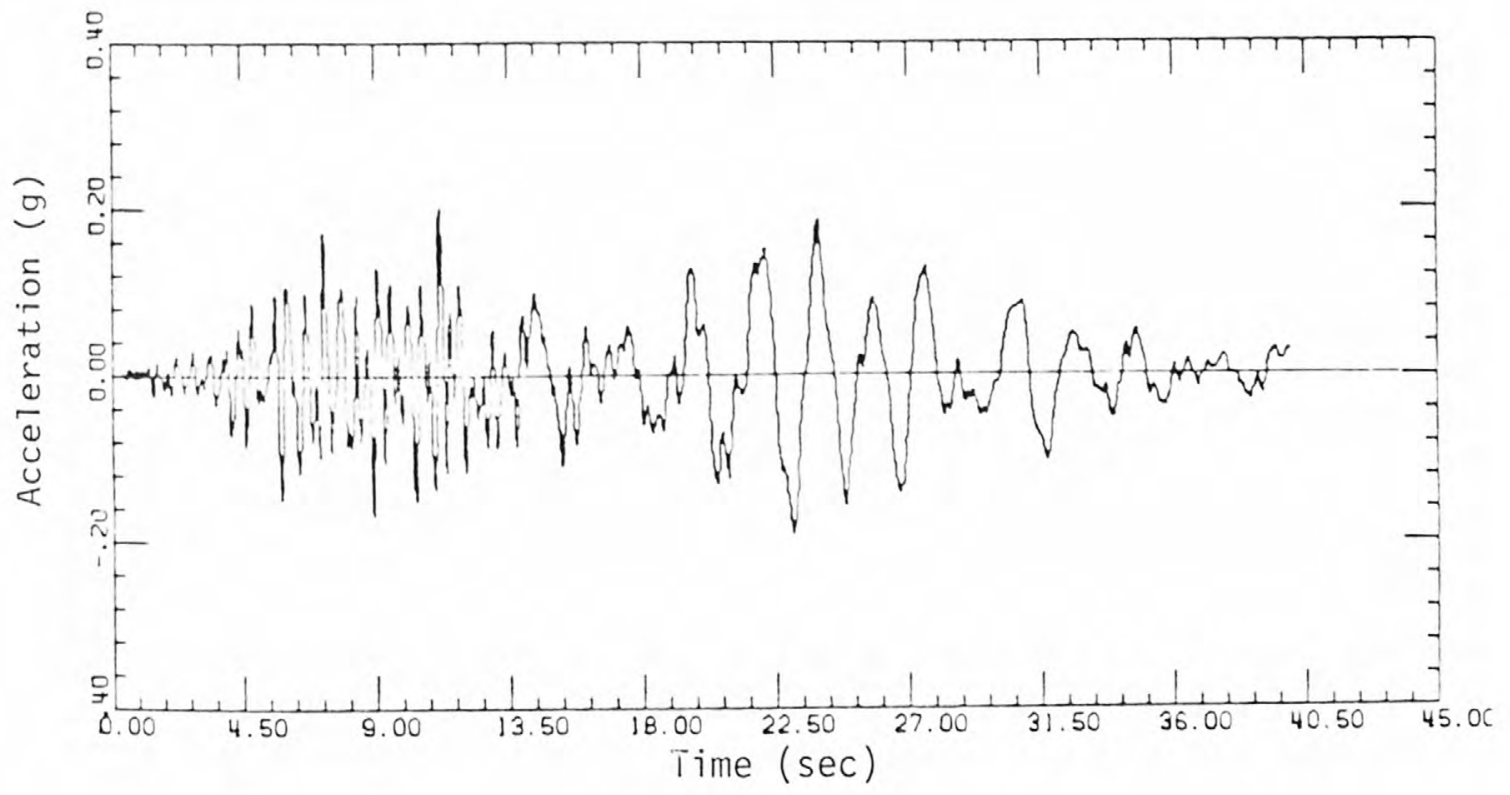

Theoretical Time History

FIGURE 5.13b MODEL 1, RECORDED AND THEORETICAL TIME HISTORIES: BANK OF CALIFORNIA BUILDING, ROOF, TRANSVERSE DIRECTION 


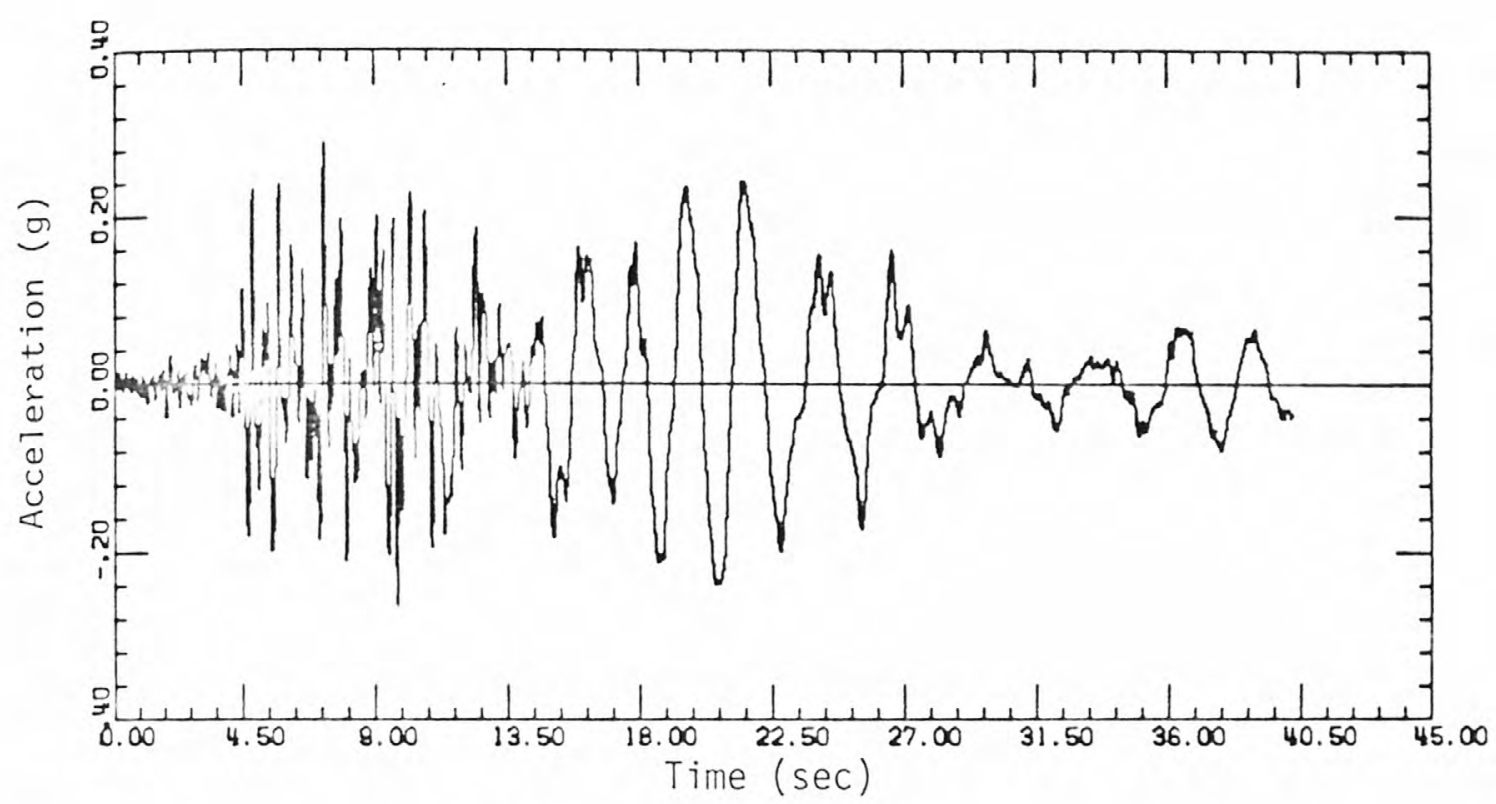

Recorded Time History

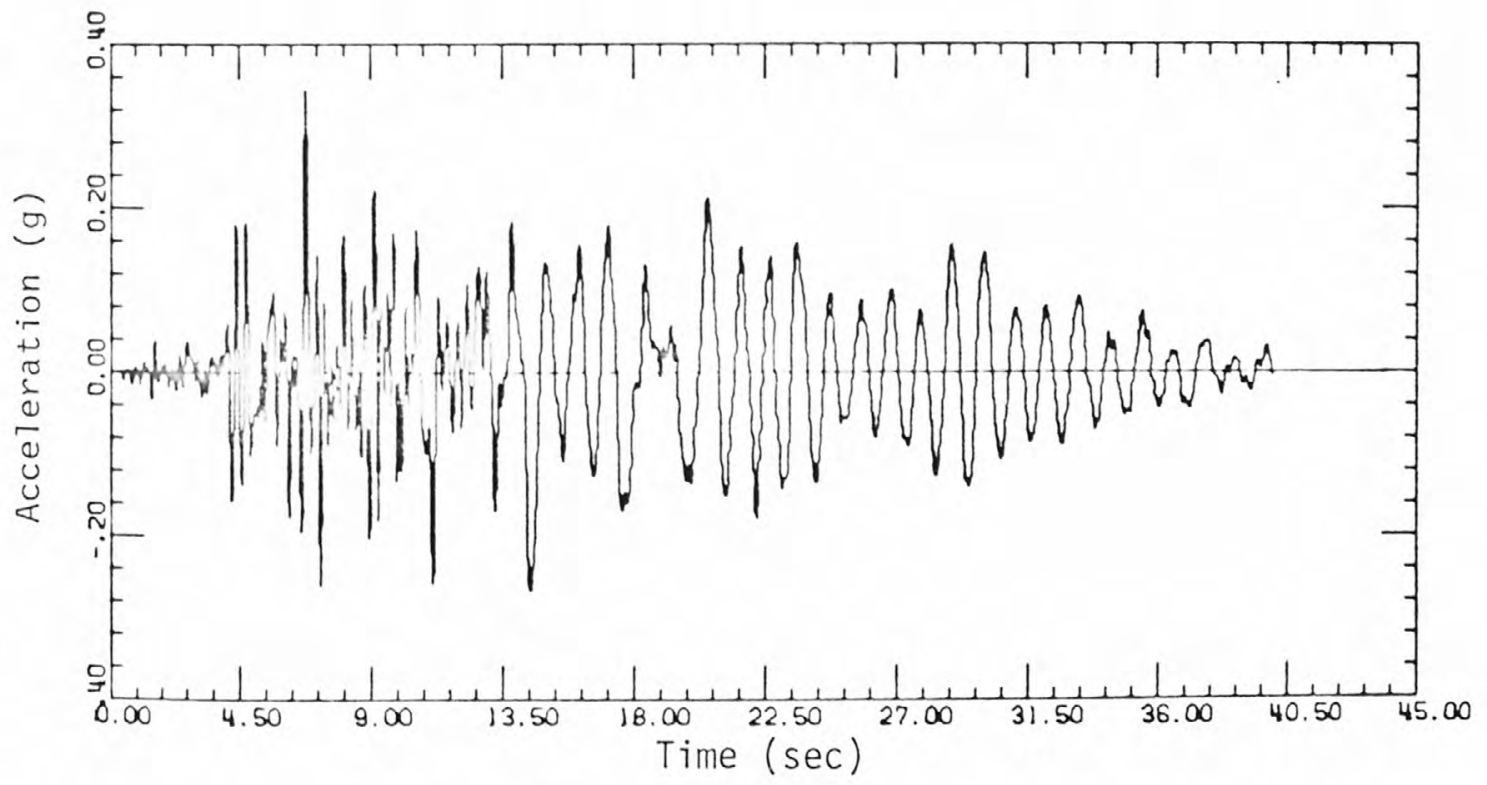

\section{Theoretical Time History}

FIGURE 5.13C MODEL 1, RECORDED AND THEORETICAL TIME HISTORIES: BANK OF CALIFORNIA BUILDING, ROOF, LONGITUDINAL DIRECTION 


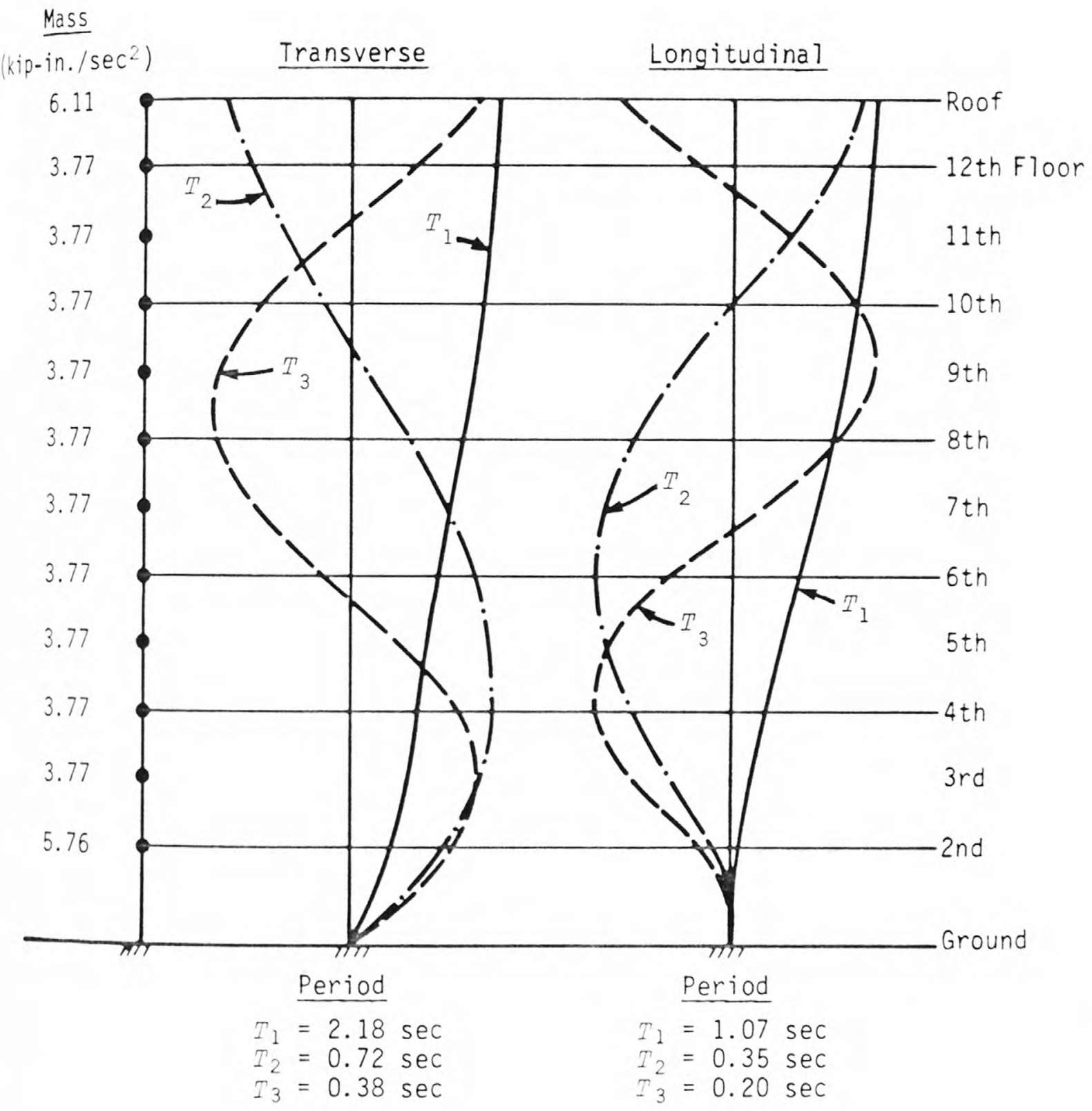

FIGURE 5.14 BANK OF CALIFORNIA BUILDING, MODEL 1: STRUCTURAL MODE SHAPES AND PERIODS 


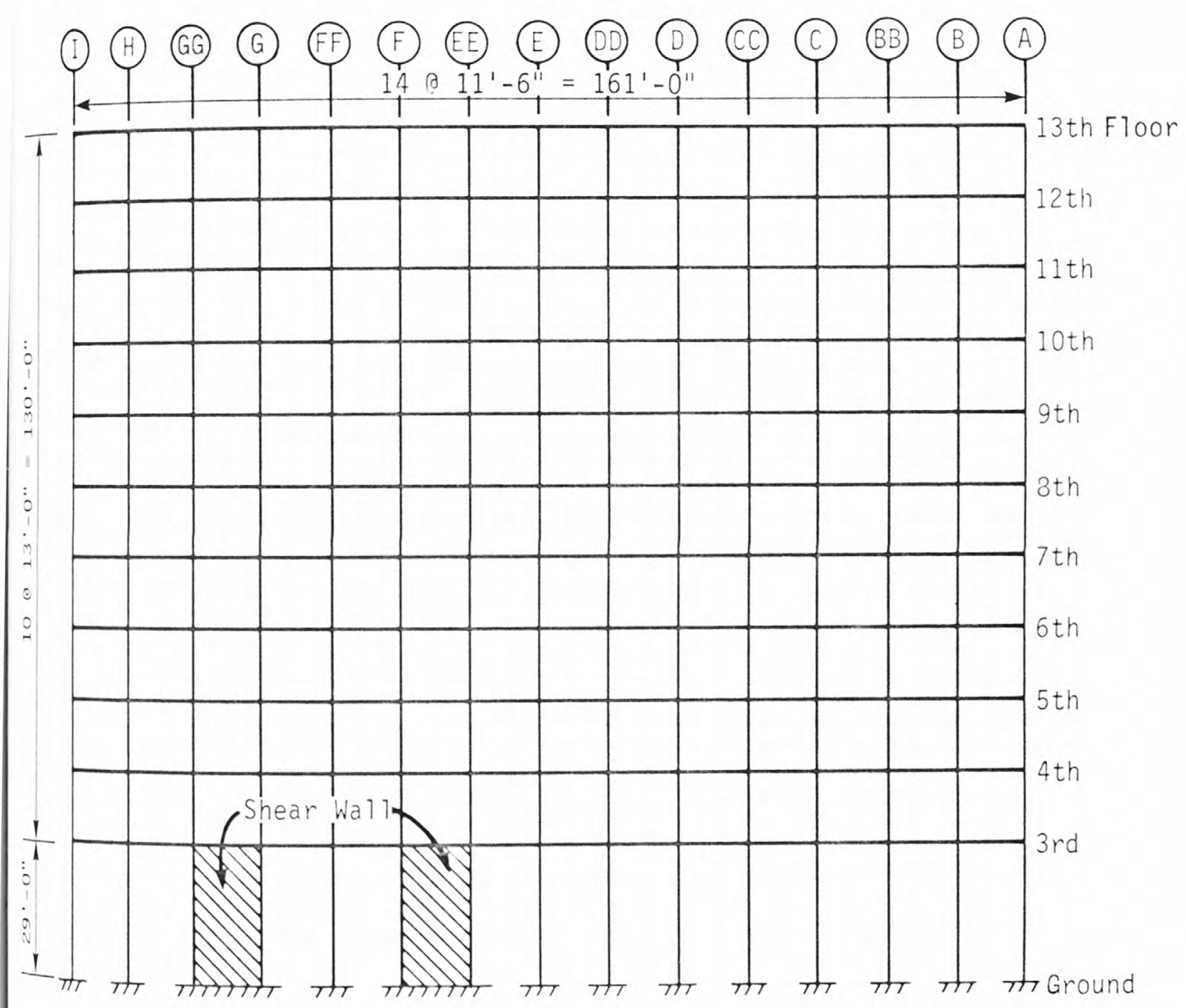

FIGURE 5.15 BANK OF CALIFORNIA BUILDING: LONGITUDINAL FRAME ON COLUMN LINE 1 


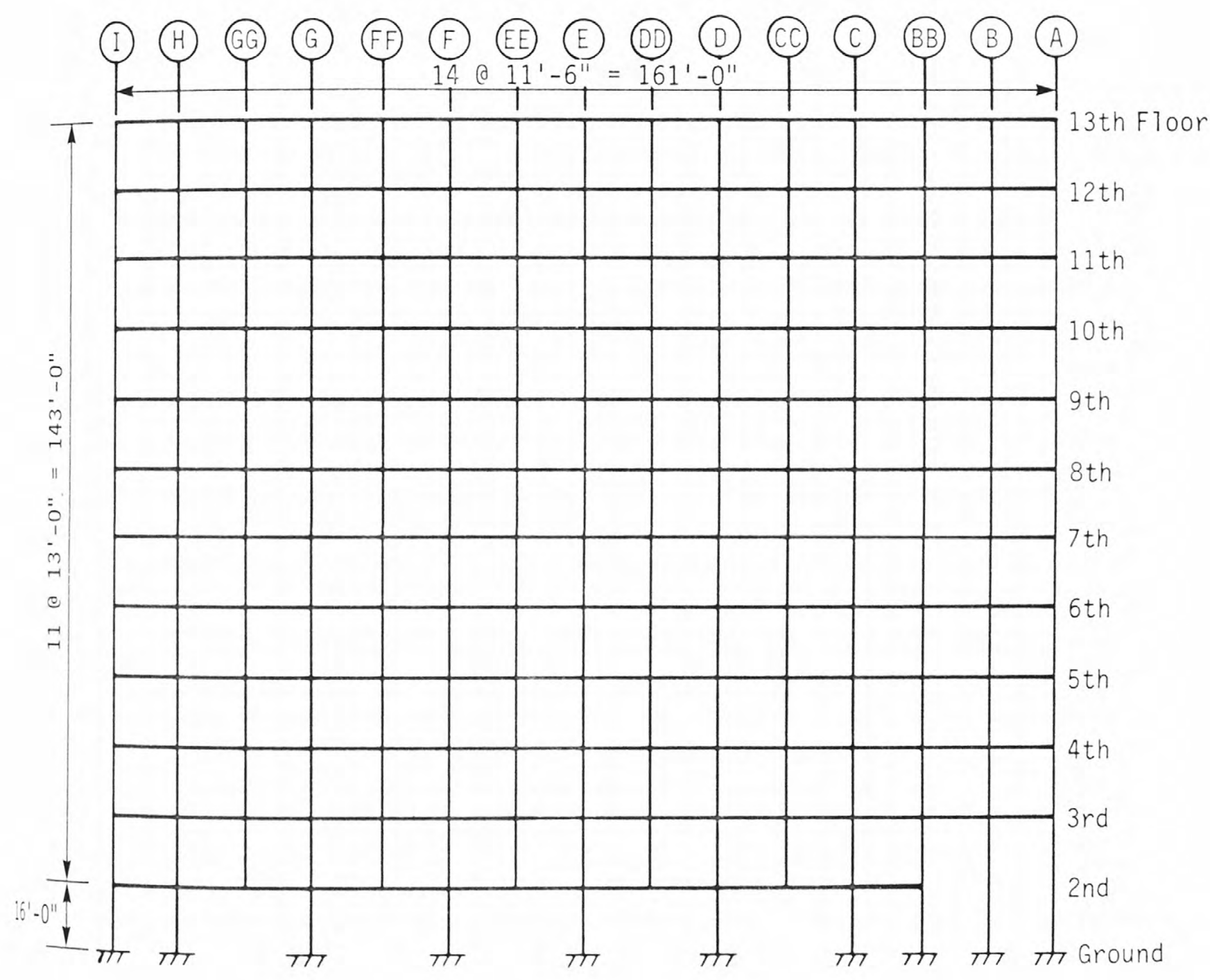

FIGURE 5.16 BANK OF CALIFORNIA BUILDING: LONGITUDINAL FRAME ON COLUMN LINE 3 


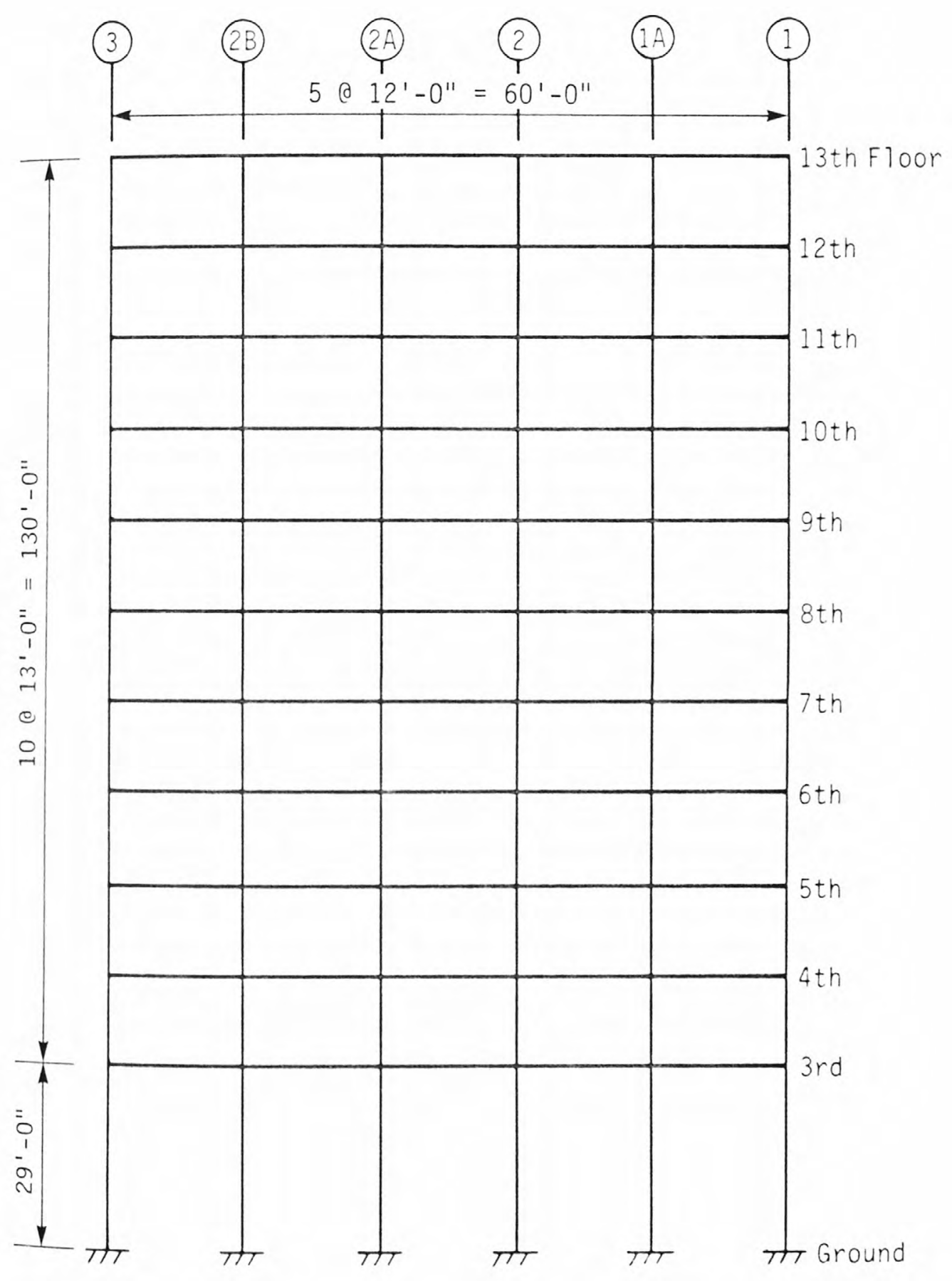

FIGURE 5.17 BANK OF CALIFORNIA BUILDING: TRANSVERSE FRAMES ON COLUMN LINES A AND I 


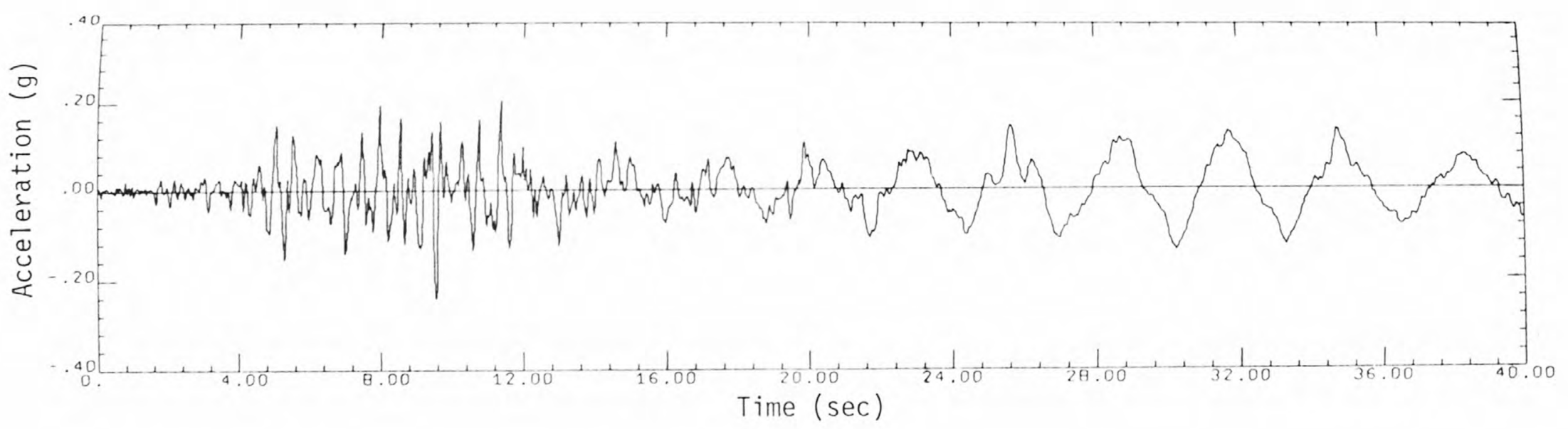

Recorded Time History

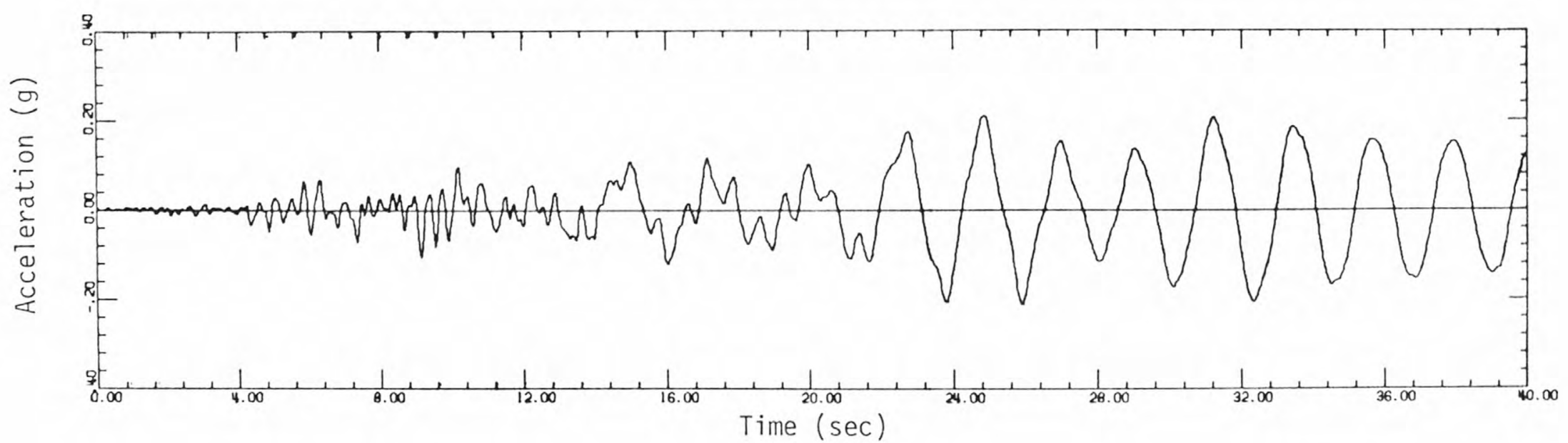

Theoretical Time History

FIGURE 5.18a MODEL 2: RECORDED AND THEORETICAL TIME HISTORIES: BANK OF CALIFORNIA BUILDING, SEVENTH FLOOR, TRANSVERSE DIRECTION 


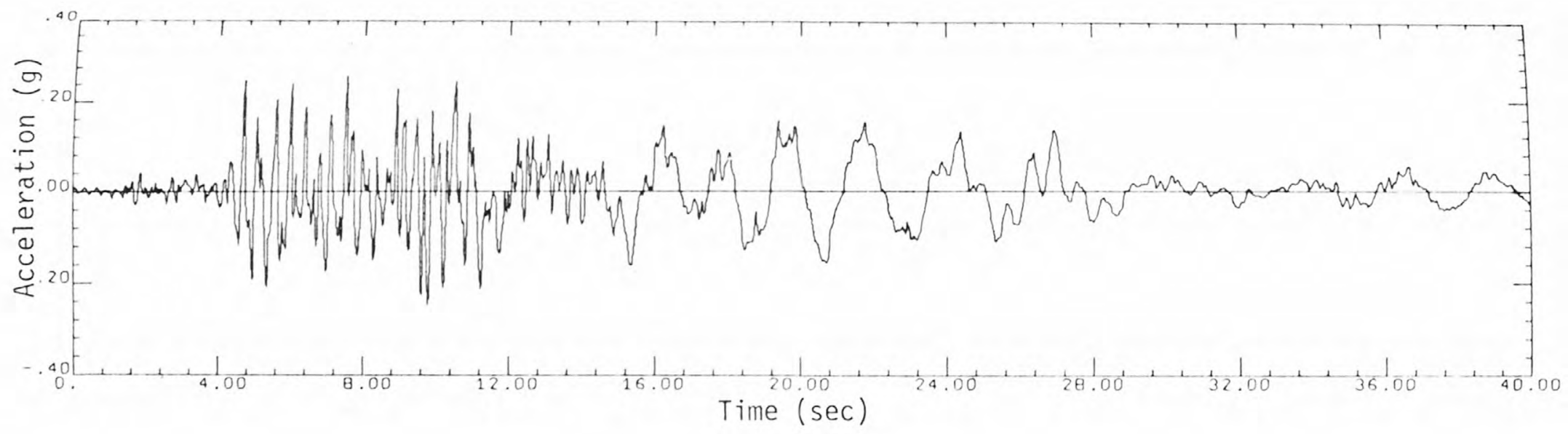

Recorded Time History

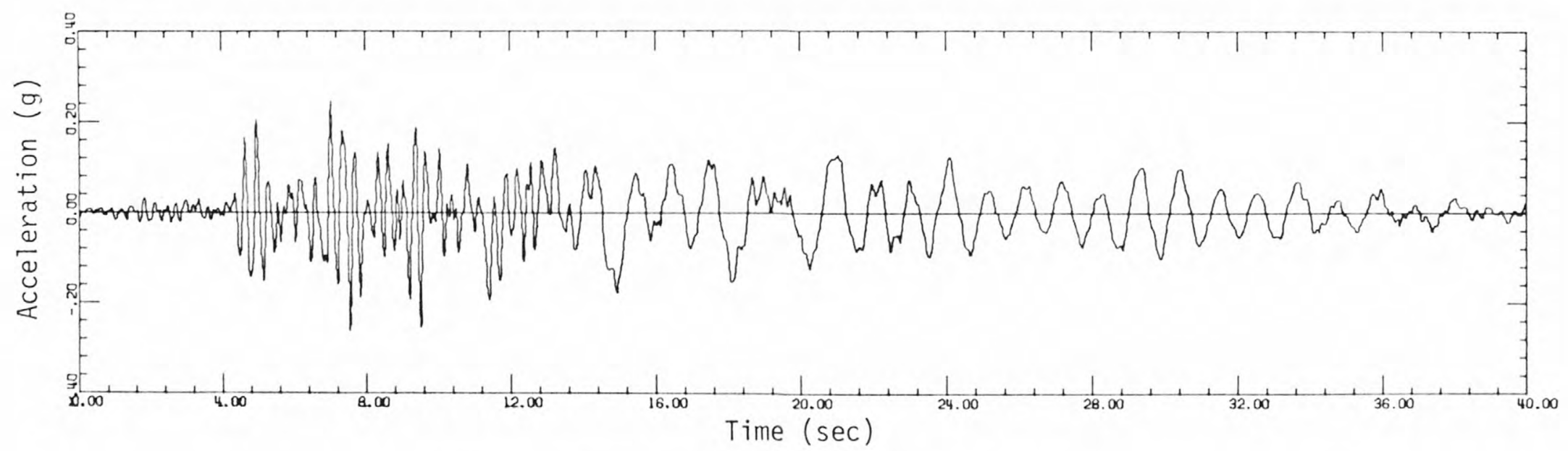

Theoretical Time History

FIGURE 5.18b MODEL 2: RECORDED AND THEORETICAL TIME HISTORIES: BANK OF CALIFORNIA BUILDING, SEVENTH FLOOR, LONGITUDINAL DIRECTION 


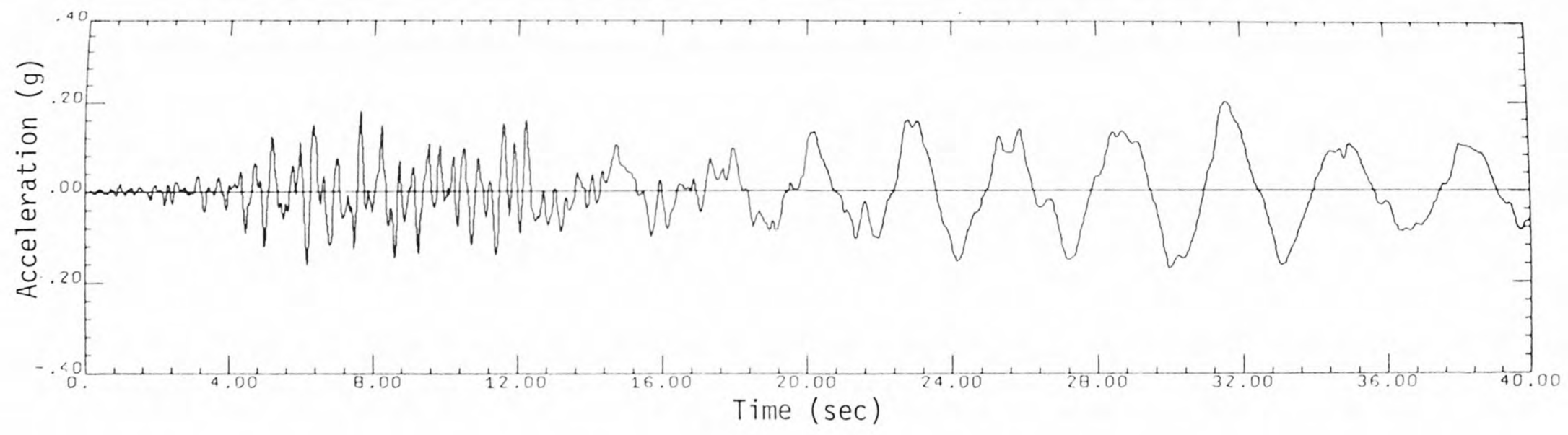

Recorded Time History

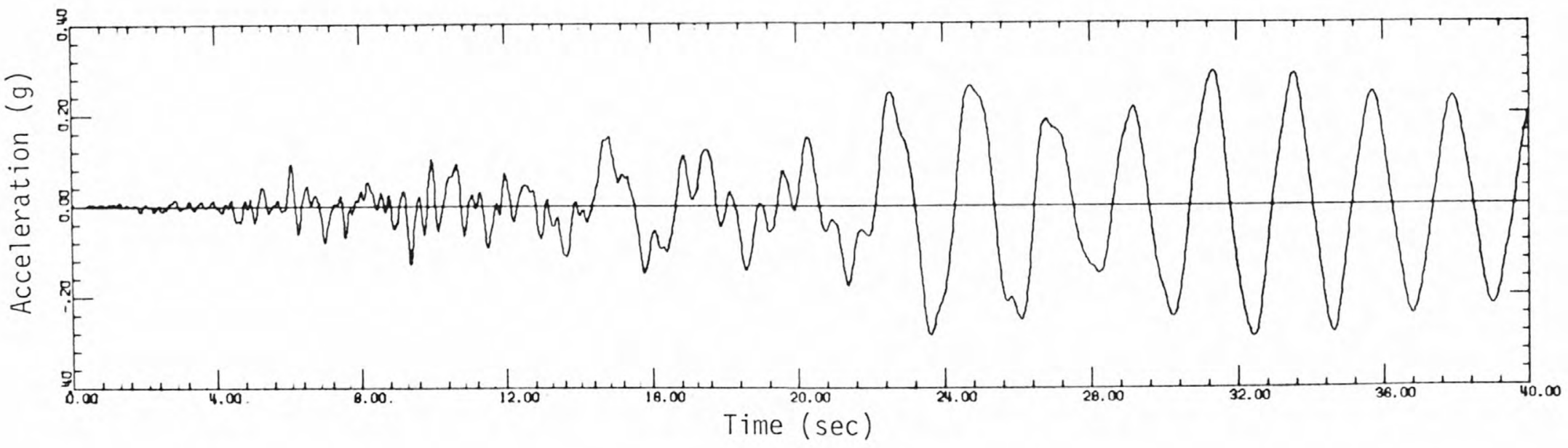

Theoretical Time History

FIGURE 5.18C MODEL 2: RECORDED AND THEORETICAL TIME HISTORIES: BANK OF CALIFORNIA BUILDING, ROOF, TRANSVERSE DIRECTION 


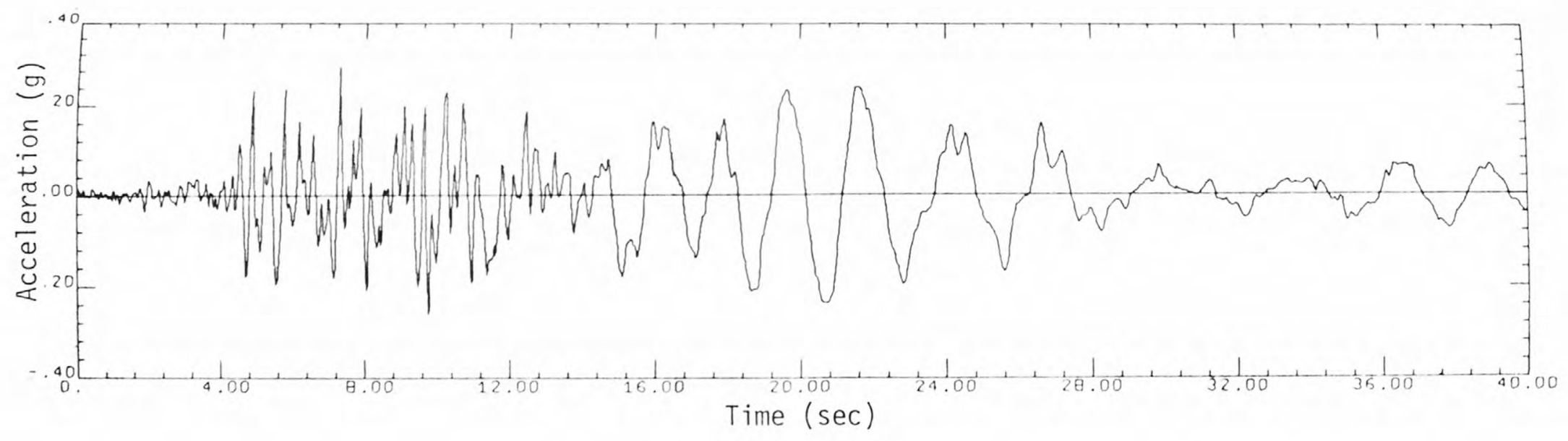

Recorded Time History

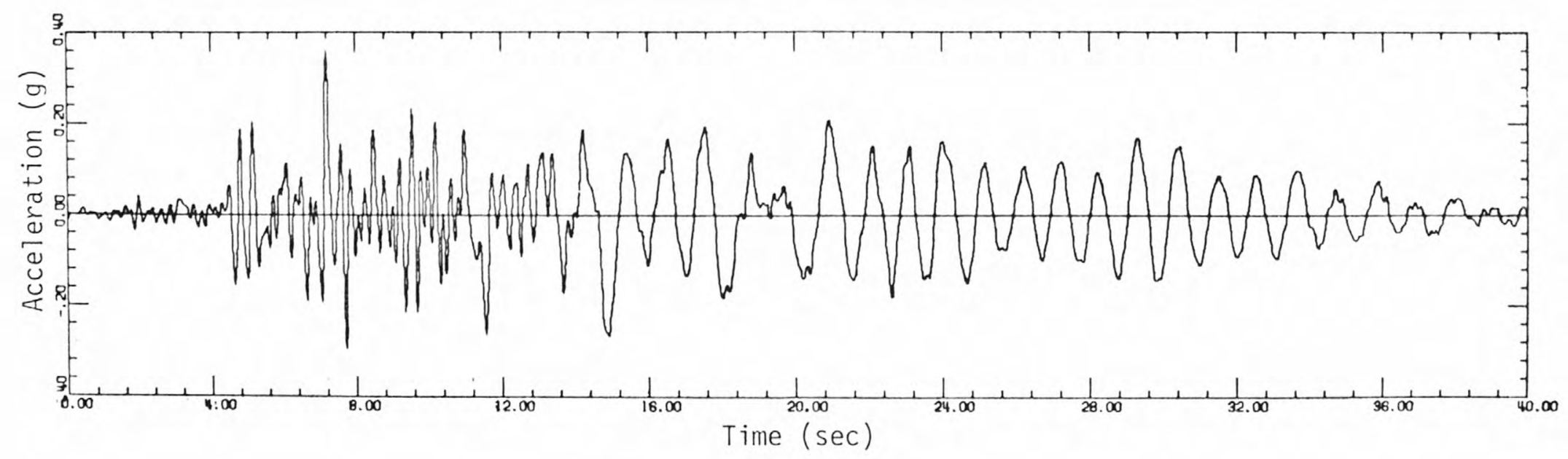

Theoretical Time History

FIGURE 5.18d MODEL 2: RECORDED AND THEORETICAL TIME HISTORIES: BANK OF CALIFORNIA BUILDING, ROOF, LONGITUDINAL DIRECTION 


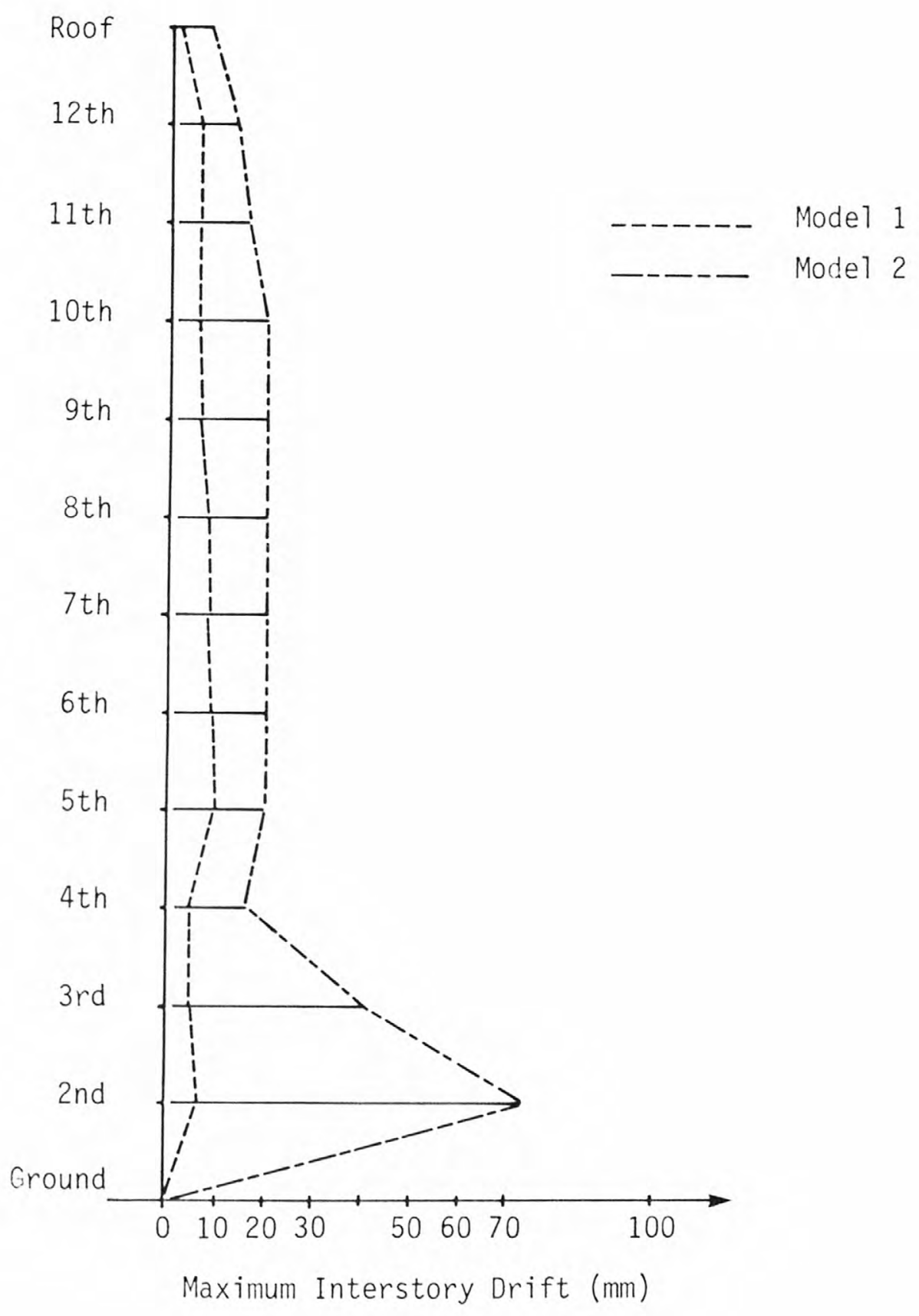

FIGURE 5.19 MAXIMUM CALCULATED INTERSTORY DRIFTS FOR THE BANK OF CALIFORNIA BUILDING, TRANSVERSE DIRECTION 


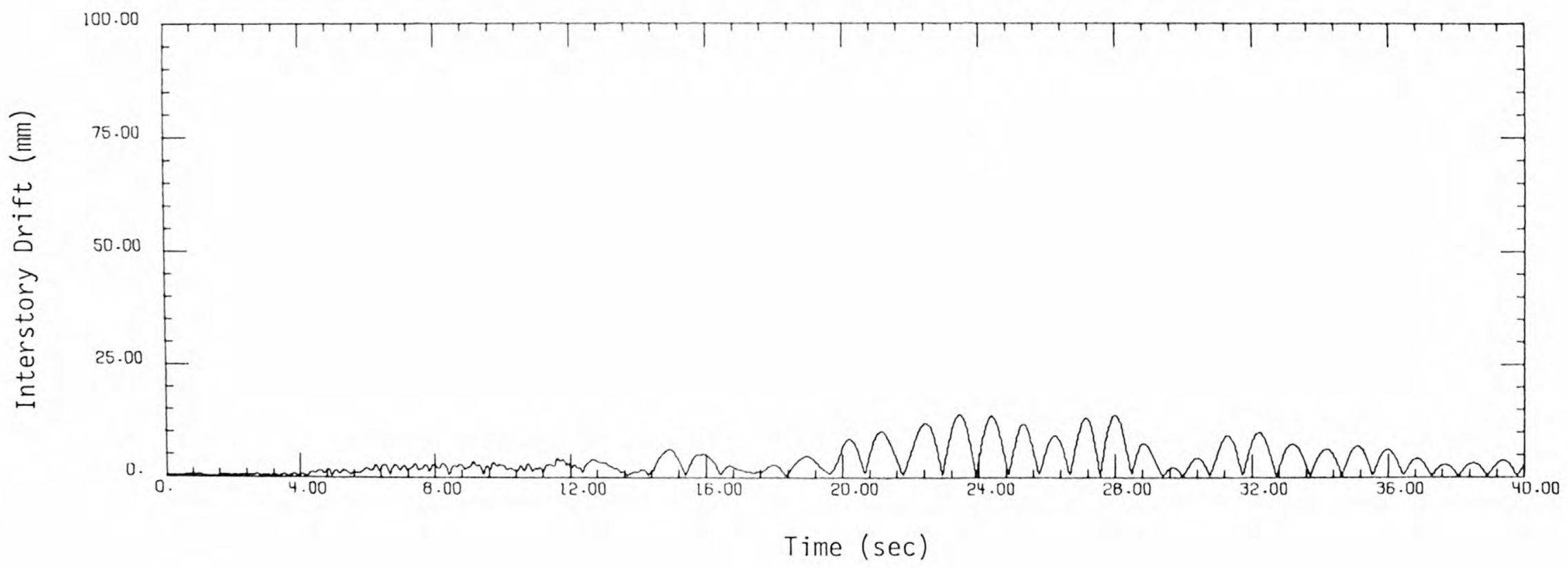

FIGURE 5.20 AVERAGE INTERSTORY DRIFT: BANK OF CALIFORNIA BUILDING, TRANSVERSE DIRECTION, MODEL 1 


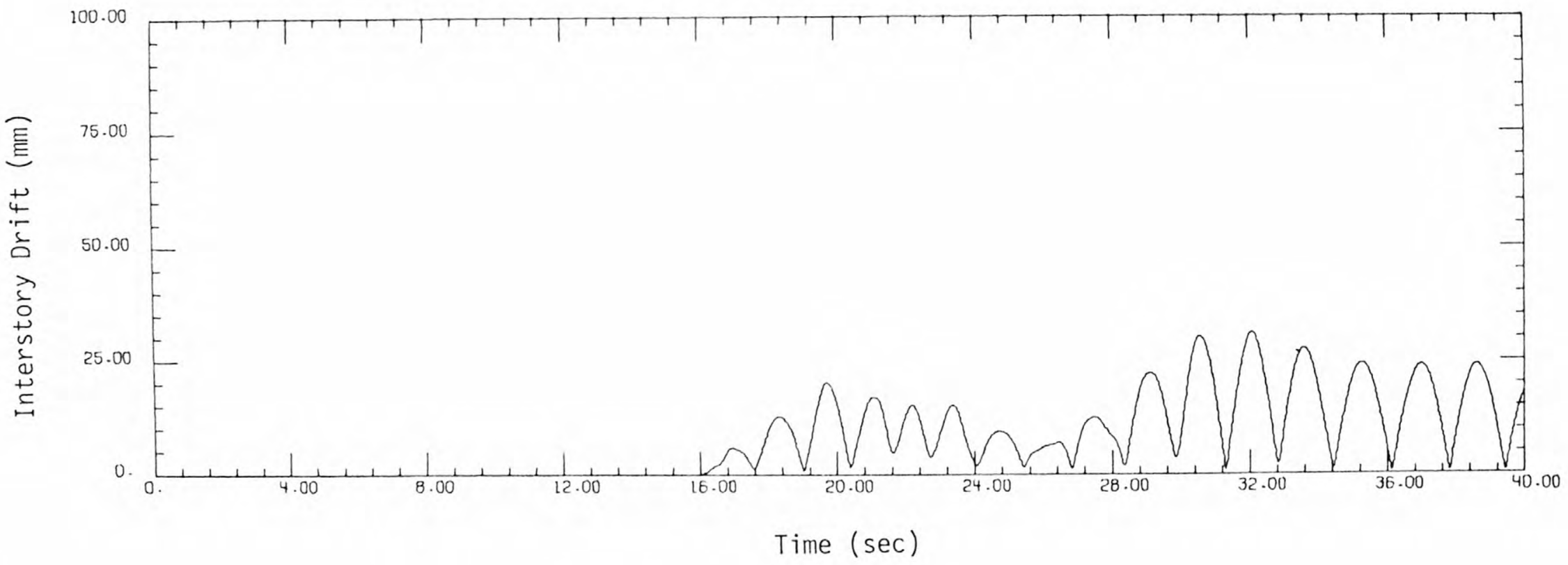

FIGURE 5.21 AVERAGE INTERSTORY DRIFT: BANK OF CALIFORNIA BUILDING, TRANSVERSE DIRECTION, MODEL 2 


\section{Time $(\mathrm{sec})$}

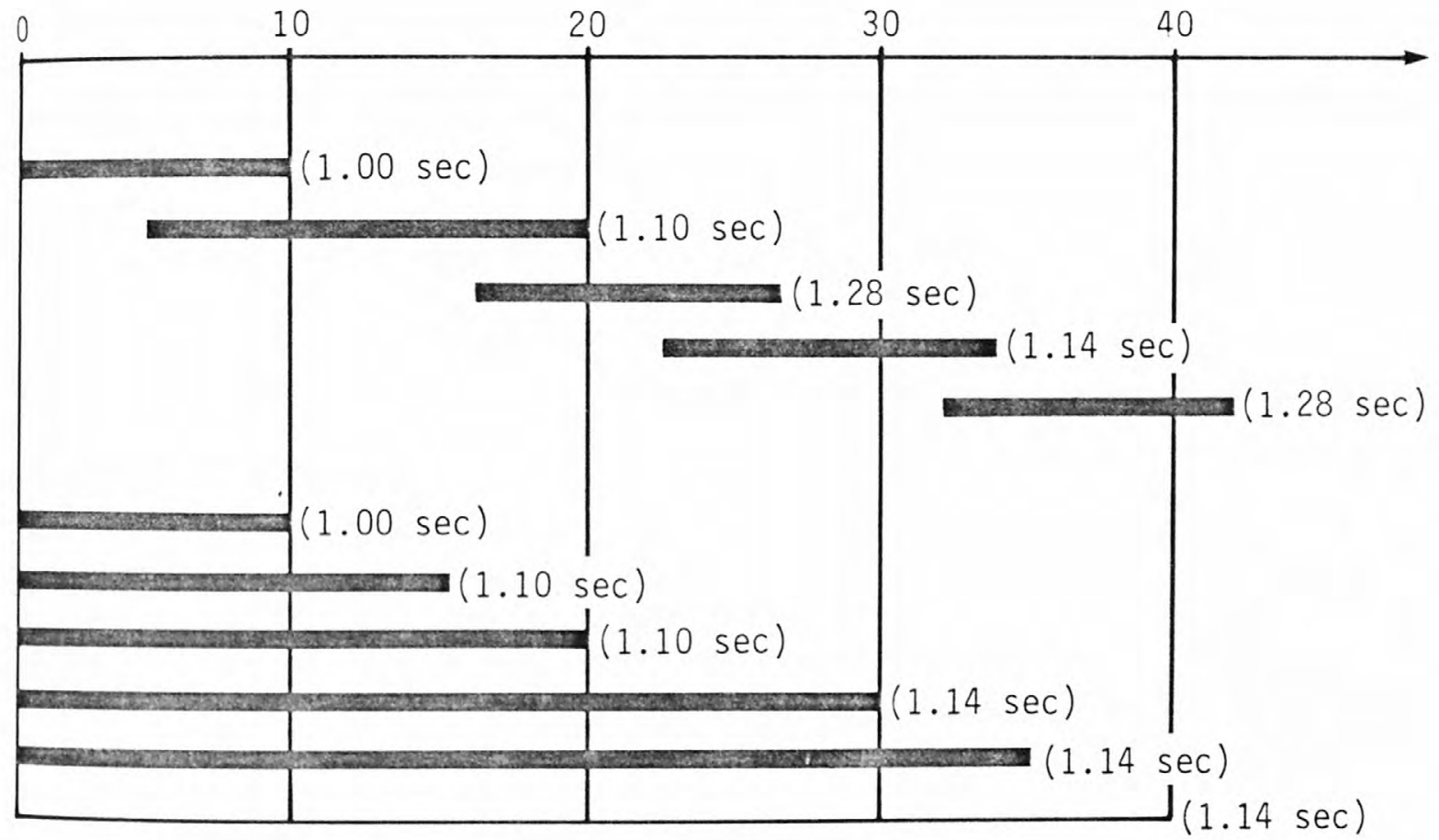

Note: Fundamental periods are shown in parentheses.

FIGURE 5.22 ORION AVENUE HOLIDAY INN: FUNDAMENTAL PERIODS OBTAINED FROM INSTANTANEOUS TRANSFER FUNCTIONS, LONGITUDDINAL DIRECTION 
Time $(\mathrm{sec})$

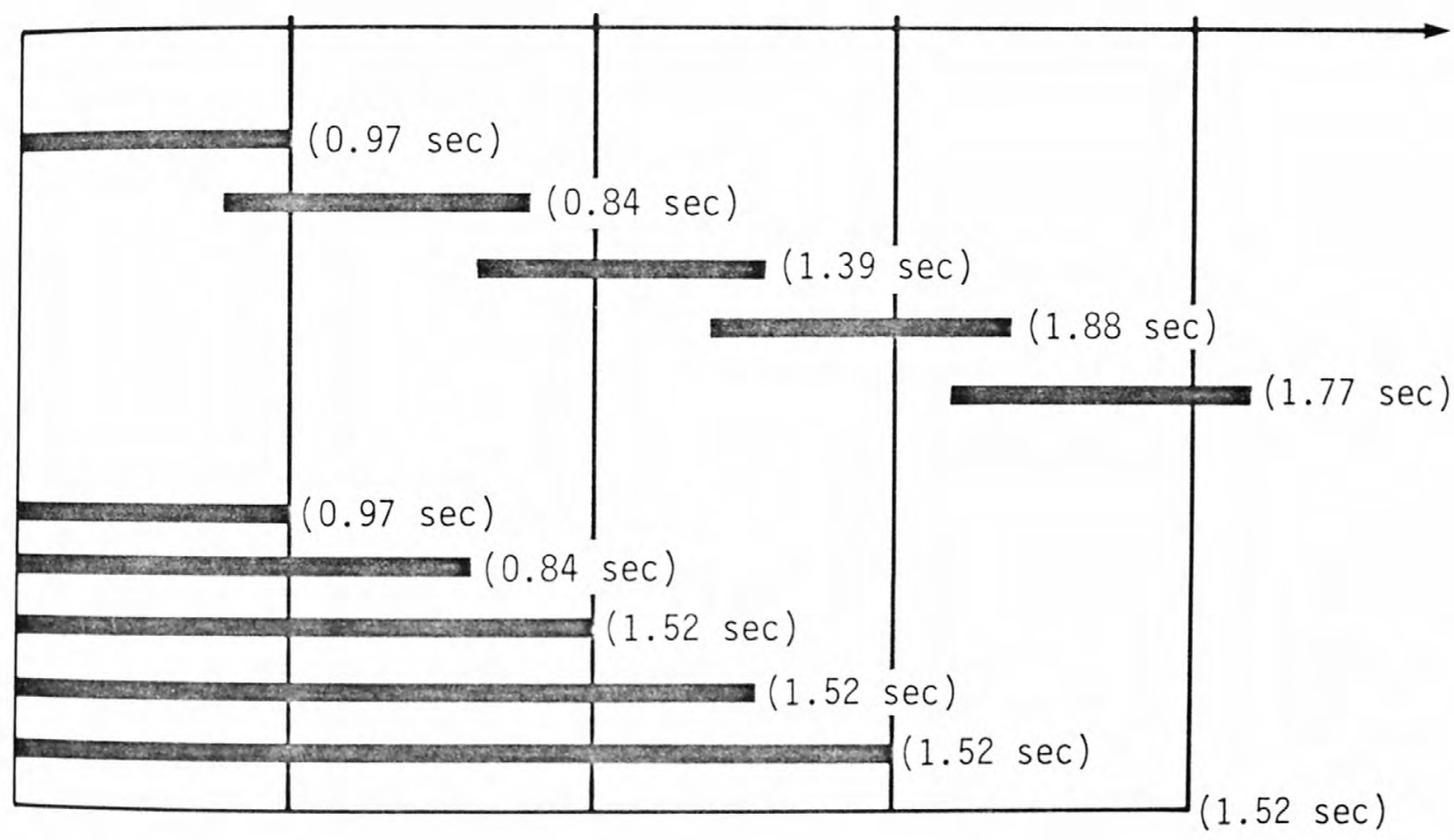

Note: Fundamental periods are shown in parentheses.

FIGURE 5.23 ORION AVENUE HOLIDAY INN: FUNDAMENTAL PERIODS OBTAINED FROM INSTANTANEOUS TRANSFER FUNCTIONS, TRANSVERSE DIRECTION 


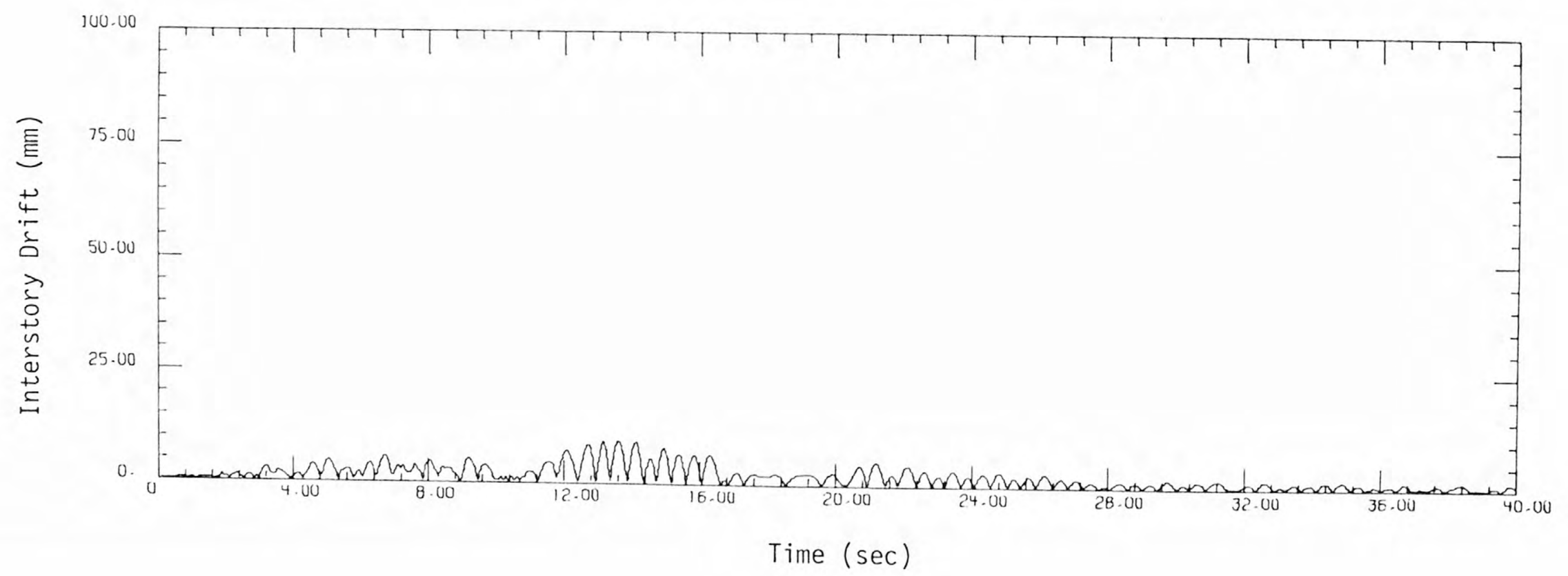

FIGURE 5.24 AVERAGE INTERSTORY DRIFT: ORION AVENUE HOLIDAY INN, LONGITUDINAL DIRECTION, MODEL 1 


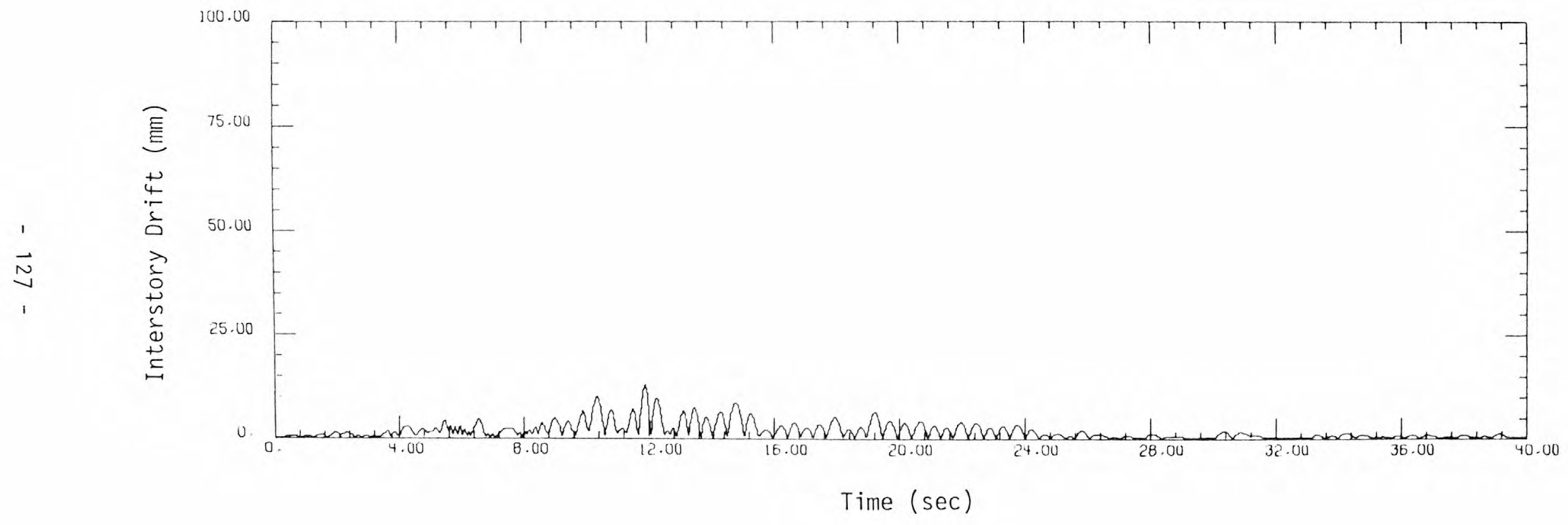

FIGURE 5.25 AVERAGE INTERSTORY DRIFT: ORION AVENUE HOLIDAY INN, TRANSVERSE DIRECTION, MODEL 1 


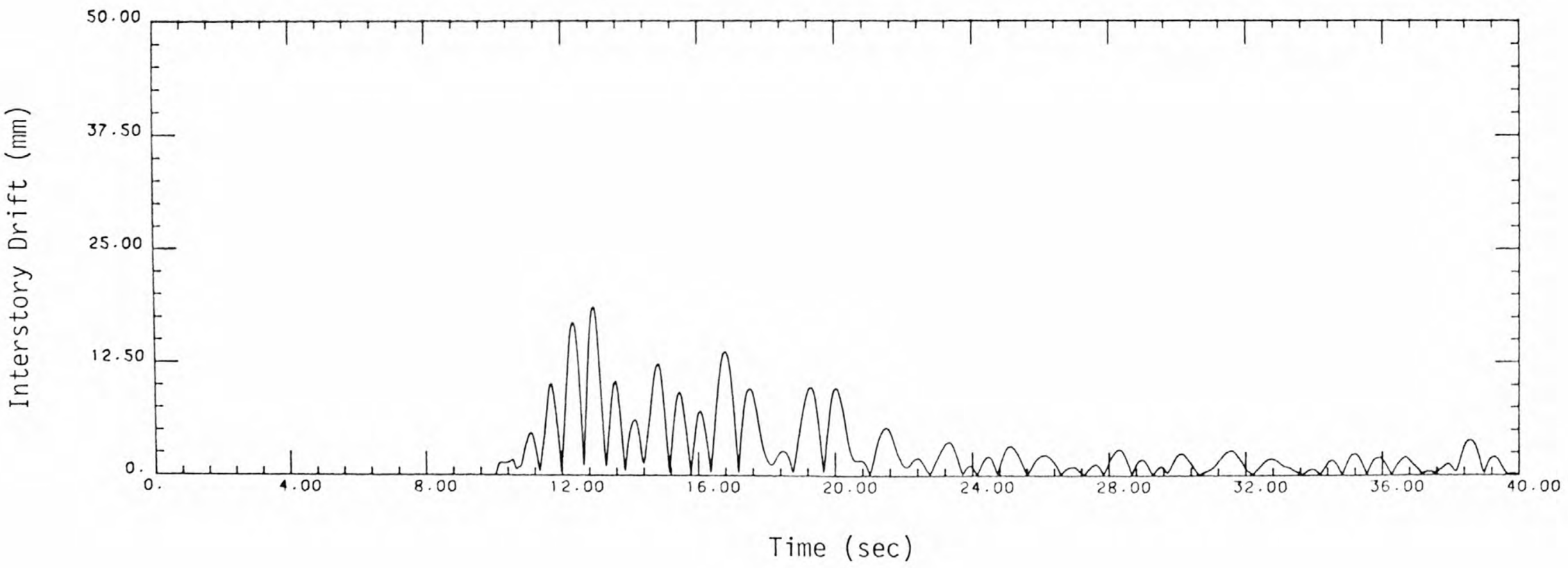

FIGURE 5.26 AVERAGE INTERSTORY DRIFT: ORION AVENUE HOLIDAY INN, LONGITUDINAL DIRECTION, MODEL 2 


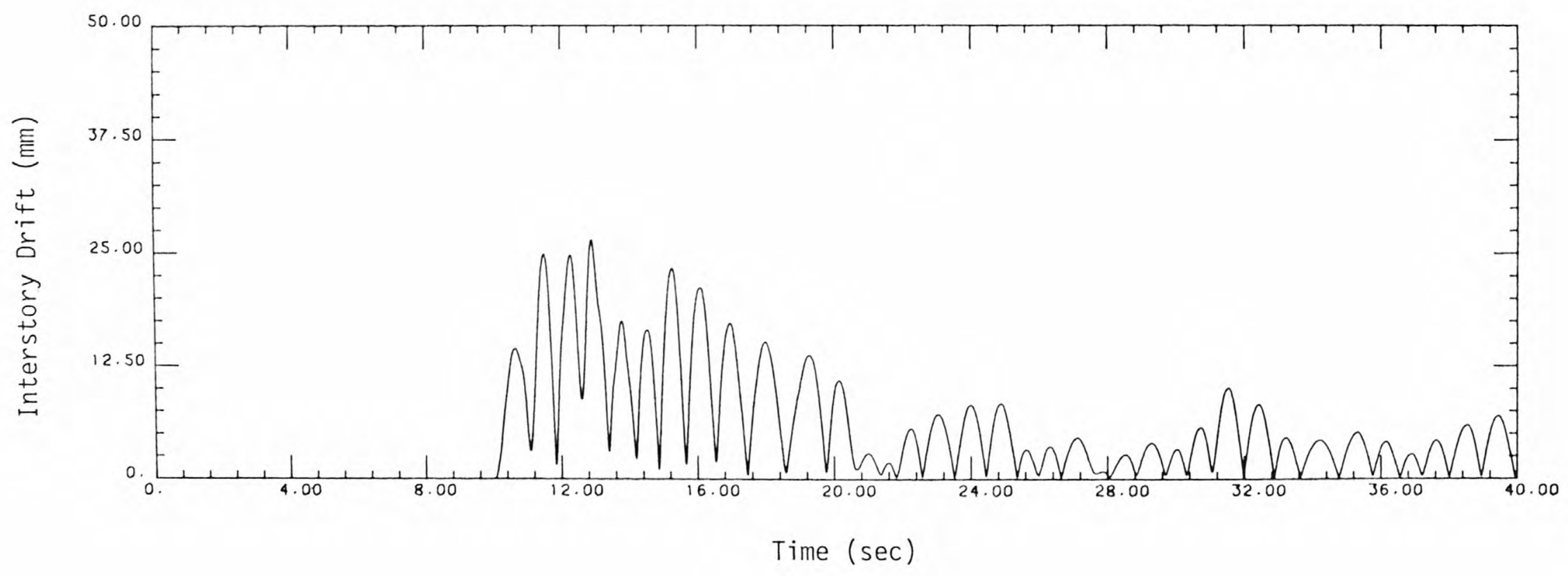

FIGURE 5.27 AVERAGE INTERSTORY DRIFT: ORION AVENUE HOLIDAY INN, TRANSVERSE DIRECTION, MODEL 2 


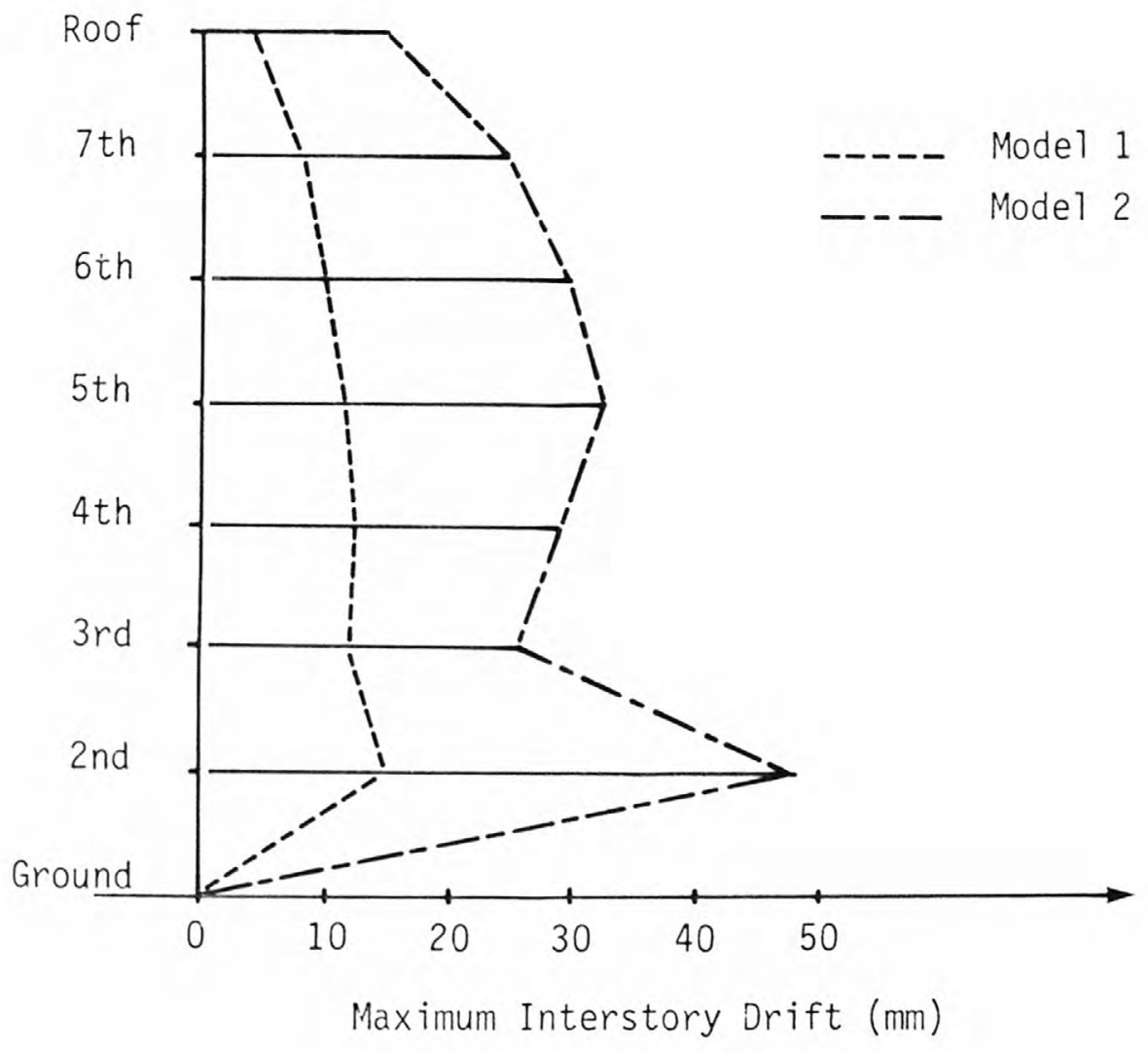

FIGURE 5.28 MAXIMUM CALCULATED INTERSTORY DRIFTS FOR ORION AVENUE HOLIDAY INN, TRANSVERSE DIRECTION 


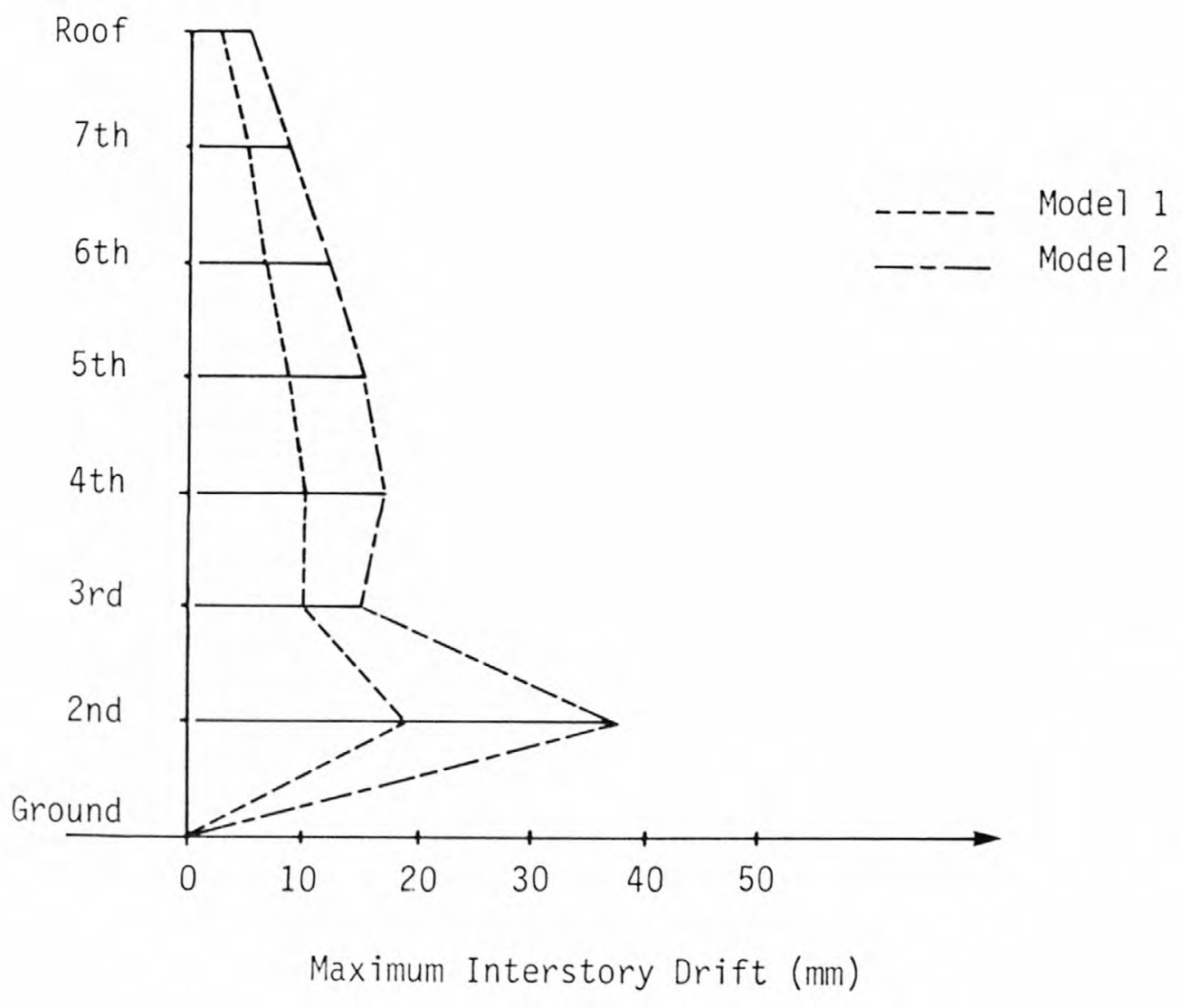

FIGURE 5.29 MAXIMUM CALCULATED INTERSTORY DRIFTS FOR ORION AVENUE HOLIDAY INN, LONGITUDINAL DIRECTION 


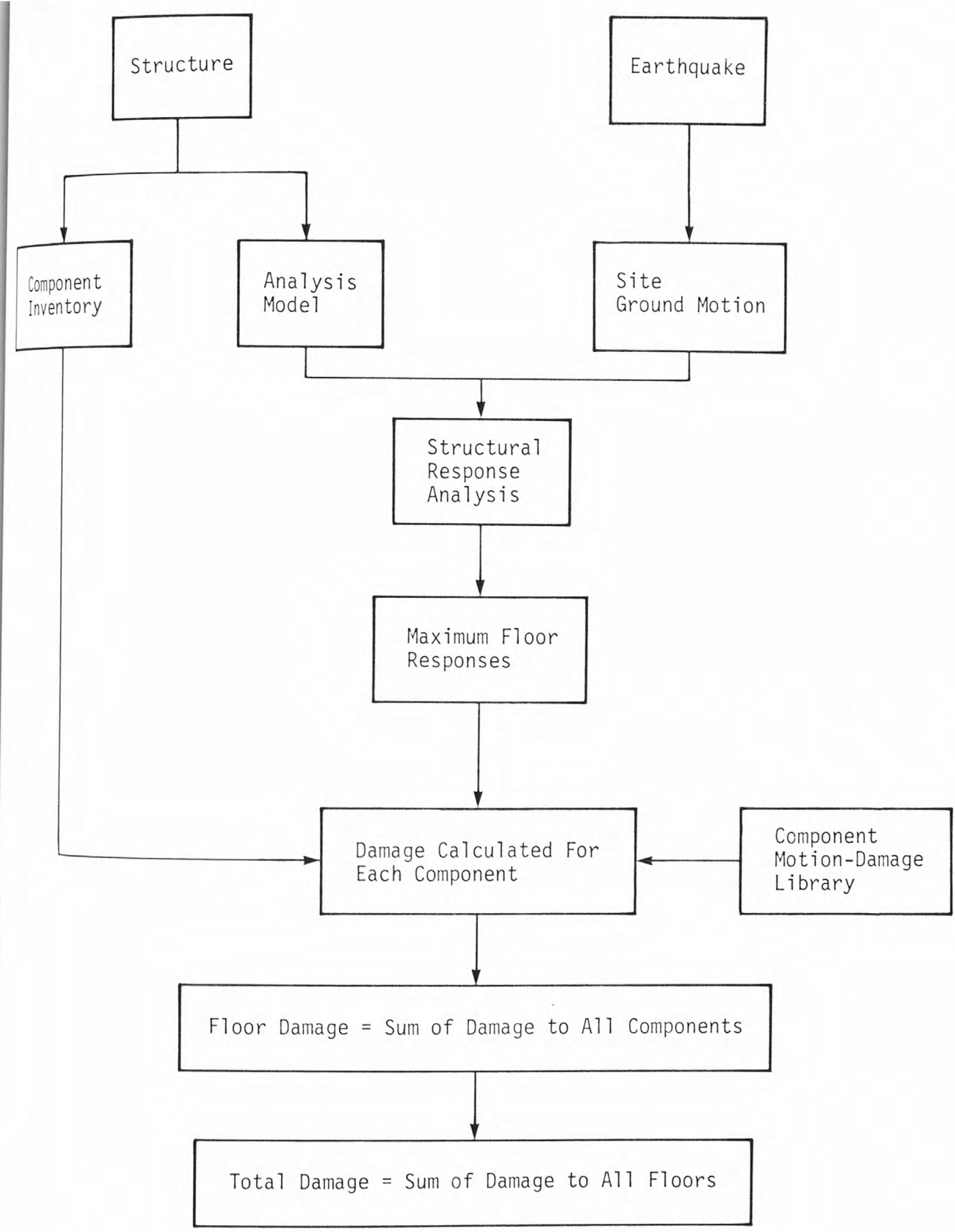

FIGURE 5.30 DAMAGE PREDICTION USING STRUCTURE COMPONENT INFORMATION 


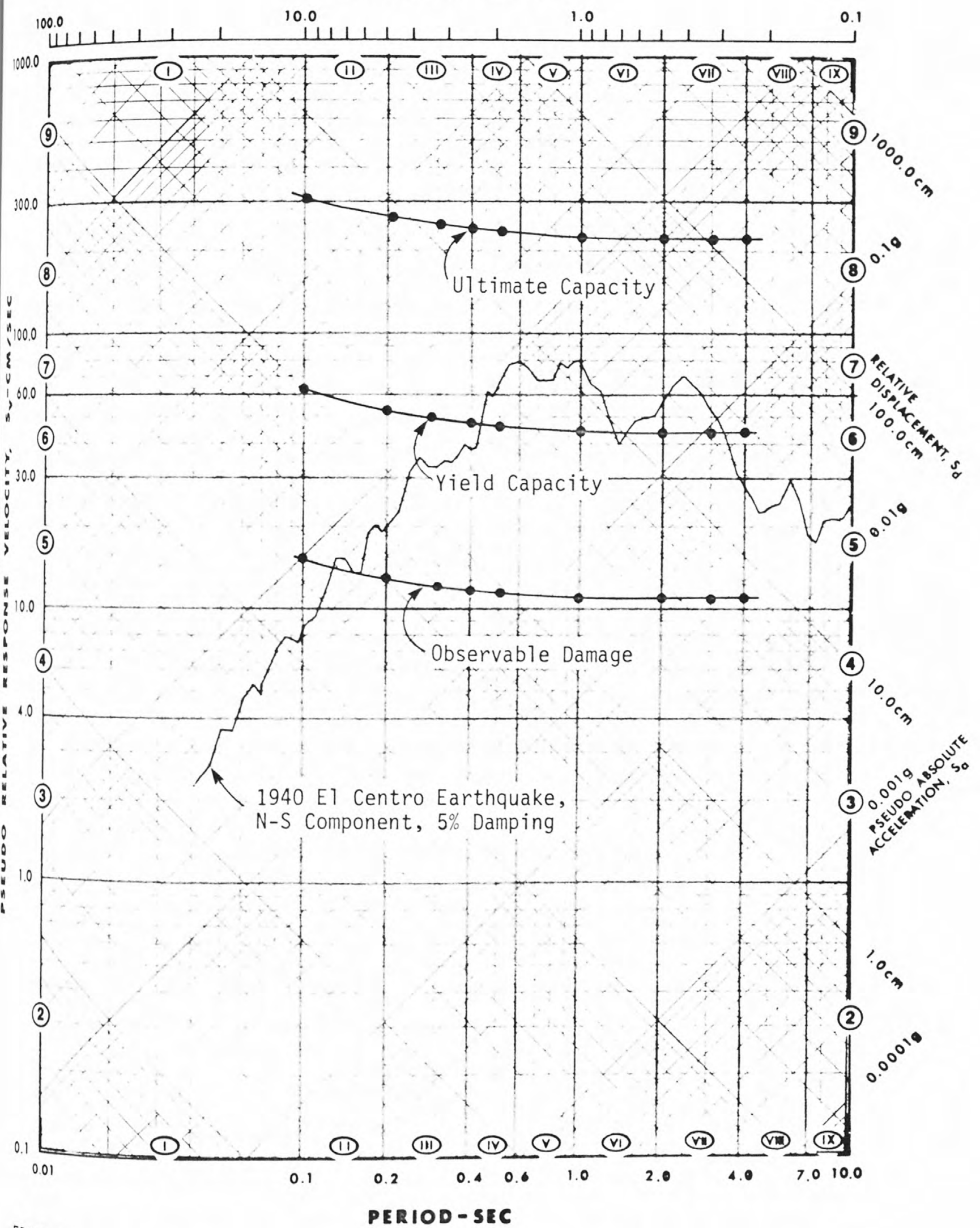

FIGURE 5.31 RESPONSE SPECTRUM AMPLITUDES FOR VARIOUS DAMAGE THRESHOLDS FOR REINFORCED CONCRETE FRAME STRUCTURES 


\section{EMPIRICAL MOTION-DAMAGE RELATIONSHIPS}

\subsection{Introduction}

Motion-damage correlation analyses can be performed and presented in a variety of ways. The most important parameters are the ground motion, the type of structure, and the damage. Effective correlation of ground motion with damage, therefore, requires careful and precise identification of the damage, idealization of the structure, and characterization of the ground motion. Proper attention to these parameters at the outset reduces scatter in the correlation results and thus minimizes the tedium involved in the work.

Motion-damage correlations that are useful for reducing hazards must be performed using parameters used in engineering design. Empirical motiondamage relationships developed with this in mind can be used to develop theoretically based damage-prediction procedures. If the theoretically based damage-prediction procedures are not too esoterically prescribed, they can be useful to the designer to reduce hazards. Several theoretical damage-prediction procedures have been proposed; these are discussed in Chapter 1. Various considerations germane to theoretically predicting damage are discussed in Chapter 5. Finally, for completeness, details of some other theoretically based damage-prediction formulations that have been proposed are presented in Appendix F.

Variability is another fact that must be considered in correlating motion and damage. Ground motion is highly random, and buildings, considering the substantial variation in design and construction, must similarly be recognized as highly variable. Accordingly, it is expectable that there will be substantial variability in calculated damage. It is important to recognize that, at least currently, the only practicable means for determining the variability of damage as a function of ground motion is from the analysis of empirical data.

\subsection{Correlation Parameters}

As stated above, the most important parameters of motion-damage correlations are the ground motion, the type of structure, and the damage. Various as- 
pects of these parameters, insofar as they must be considered for fruitful correlations and as they will be considered in this study, are discussed in this section.

\subsubsection{Ground Motion Characterization. The ground motion that a structure} might be subjected to can be identified in many ways: seismological intensity, peak ground motion parameters (acceleration, velocity, or displacement), response spectrum amplitude, or engineering intensity. The most important ground motion characteristics that affect dynamic structure response and damage are: motion amplitude, frequency content, periodicity, and duration. Insofar as these characteristics influence structure response and damage, they are all included in the response spectrum characterization, except duration. Ground motion duration is included to the extent that peak response is calculated, but structure response duration is not included. Structure response duration is not of significant importance for low levels of damage and for ductile materials (e.g., steel), but it is significant at high damage levels and for brittle materials (e.g., concrete). Another limitation of the response spectrum is that only linear response is depicted. At low levels of damage this is not a serious shortcoming, but at high damage levels it is.

Although response spectrum amplitudes are not a perfect means of characterizing ground motion, it is clear that spectral values are better than either seismological intensities or peak ground motion values. Accordingly, EIS values will be used as the principal ground motion characterization. Approximations to account for duration and for nonlinearity will be made where deemed necessary in the correlation analysis.

6.2.2 Structure Idealization. Structures can be idealized in many ways, for example by material type (e.g., steel, concrete, masonry) or construction system (e.g., frame, shear-wall, braced frame). The most important considerations for idealizing a structure are the dynamic response of the structure and the manner in which the construction materials and type imply that it will be damaged.

A multi-degree-of-freedom model is, of course, the most appropriate means to represent the dynamic response aspect of the problem. For the type of analysis being conducted, this is simply too elaborate, and approximations must 
be made. The most important aspect of dynamic response that needs to be included in the analysis is the characteristics of the fundamental mode of the building. These include period, mode shape, and damping. Period and damping can be readily included, but to include mode shape would require establishing another subset to the analysis. Accordingly, mode shape will be disregarded and will be recognized as contributing to the scatter in the results of the analysis. Consistent with the EIS, $5 \%$ damping will be assumed.

Construction materials and the type of construction system have a significant effect on the manner and degree in which damage is manifested. Accordingly, various classifications of structural systems and nonstructural components will be considered as follows:

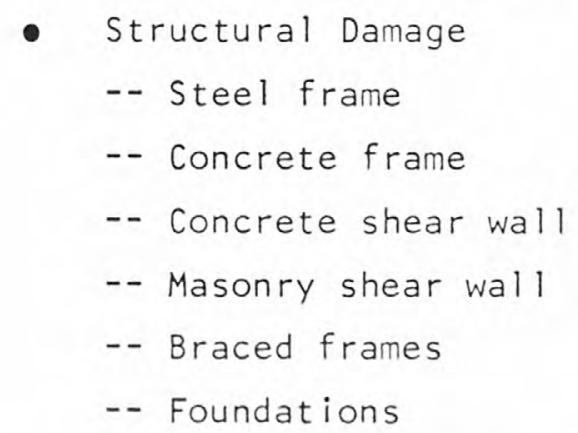

- Nonstructural Damage

-- Drywall partitions

-- Brick infill walls

-- Concrete block infill walls

-- Glazing

-- Cladding

-- Other (ceilings, mechanical and electrical equipment, etc.)

- Damage to Contents

\subsubsection{Damage Identification. The principal consideration in establishing} an appropriate means of describing damage is that it satisfy user needs. To that end, two quantities are useful: the incidence of damage and the degree of damage. Quantitatively, these are calculated as follows:

$$
\begin{aligned}
& \text { Damage ratio }(D R) \text {, defined by } \\
& \qquad D R=\frac{\text { number of buildings damaged }}{\text { total number of buildings }}
\end{aligned}
$$




$$
\begin{aligned}
& \text { Damage factor }(D F) \text {, defined by } \\
& \qquad D F=\frac{\text { damage repair cost }}{\text { replacement value of building }}
\end{aligned}
$$

These two nondimensional parameters are quite general and can be defined for a geographical area or subarea as well as for various building classifications or types of construction, e.g., steel, concrete, or masonry. They can also be defined for various types of damage, e.g., structural, nonstructural, or glass.

All that is needed for the ultimate development of a damage-prediction procedure is the DF and its variability. Tracking the DR facilitates a more complete understanding of the damage process.

\subsection{Correlation Analys is Procedures}

The principal correlation analyses will entail relating the two parameters -$D R$ and DF - to corresponding EI values.

Three statistics useful for establishing damage probability density functions (shown for DF) are:

The mean of the damage probability density function $m_{D F}$

$$
m_{D F}=\frac{1}{N} \sum_{i=1}^{N} D F_{i}
$$

The variance of the damage probability density function, $\sigma_{\mathrm{DF}}^{2}$

$$
\sigma_{D F}^{2}=\frac{1}{N} \sum_{i=1}^{N}\left(D F_{i}-m_{D F}\right)^{2}
$$

The standard deviation of the damage probability density function, $\sigma_{D F}$

$$
\sigma_{D F}=\sqrt{\sigma_{D F}^{2}}
$$


These statistics can be interpreted as geometric properties of the damage probability function. They are, respectively: the center of gravity, $m_{D F}$; the moment of inertia about the centroid, $\sigma_{D F}^{2}$; and the radius of gyration, $\sigma_{D F}$, of the area under the probability density function, which is considered as a plane curve.

A final statistic is the coefficient of variation, which is defined as:

$$
V_{D F}=\sigma_{D F} / m_{D F}
$$

$V_{D F}$ measures the relative uncertainty or relative spread of the probability density function. Large values of $V_{D F}$ are associated with large relative uncertainties, and vice versa.

Another means of revealing damage information is the damage probability matrix concept proposed by Whitman (1973). (See Tables 3.2 and 6.1.) Because these matrices so clearly reveal the shape of the damage probability density function, this information will also be calculated and presented.

To the extent that the motion-damage information can be linearized, correlation coefficients, $r$, will be calculated as follows (shown for DF):

$$
r_{D F}=\frac{\sum x y}{\sqrt{\left(\sum x^{2}\right)\left(\sum y^{2}\right)}}
$$

where:

$$
\begin{aligned}
& x=E I-\overline{E I} \\
& y=D F-\overline{D F}
\end{aligned}
$$

\subsection{Additional Studies for Completion}

The work remaining for this task, Task IV, is that of utilizing the data base to calculate the empirical motion-damage relationships. This work will be executed upon completion of Task III. 
TABLE 6.1

GENERAL FORM OF DAMAGE PROBABILITY MATRIX

\begin{tabular}{|c|c|c|c|c|c|c|c|c|}
\hline \multirow{2}{*}{$\begin{array}{l}\text { Damage } \\
\text { State }\end{array}$} & \multirow{2}{*}{$\begin{array}{l}\text { Structural } \\
\text { Damage }\end{array}$} & \multirow{2}{*}{$\begin{array}{c}\text { Nonstructural } \\
\text { Damage }\end{array}$} & \multirow{2}{*}{$\begin{array}{c}\text { Damage } \\
\text { Rat io } \\
(\%)\end{array}$} & \multicolumn{5}{|c|}{ Intensity of Earthquake } \\
\hline & & & & $\mathrm{V}$ & VI & VII & VIII & IX \\
\hline 0 & none & none & $0-0.05$ & 95 & 79 & 33 & 6 & 0 \\
\hline 1 & none & minor & $0.05-0.3$ & 5 & 18 & 34 & 19 & 2 \\
\hline 2 & none & localized & $0.3-1.25$ & 0 & 3 & 20 & 44 & 18 \\
\hline 3 & not noticeable & widespread & $1.25-3.5$ & 0 & 0 & 10 & 13 & 30 \\
\hline 4 & minor & substantial & $3.5-7.5$ & 0 & 0 & 3 & 6 & 20 \\
\hline 5 & substantial & extensive & $7.5-20$ & 0 & 0 & 0 & 12 & 10 \\
\hline 6 & major & nearly total & $20-65$ & 0 & 0 & 0 & 0 & 7 \\
\hline 7 & \multirow{2}{*}{\multicolumn{2}{|c|}{$\begin{array}{l}\text { building condemned } \\
\text { collapse }\end{array}$}} & 100 & 0 & 0 & 0 & 0 & 8 \\
\hline 8 & & & 100 & 0 & 0 & 0 & 0 & 5 \\
\hline
\end{tabular}

Source: Whitman (1973) 


\section{REFERENCES}

Agbabian Associates, Correlation of Ground Response Spectra With Modified Nerealii Intensity, June 1977.

Algermissen, S. T., K. V. Steinbrugge, and H. J. Lagorio, Estimation of Earthquake Losses to Buildings (Except Single Eamily Dwellings), USGS OpenFile Report 78-441, 1978 (a).

Algermissen, S. T., M. B. McGrath, and S. L. Hanson, DeveZopment of a Technique for the Rapid Estimation of Earthquake Losses, USGS Open-File Report 78-440, 1978 (b).

Anagnostopoulos, S. A., Nonlinear Dynomic Response and Ductility Requirements of Building Stmetures Subject to Earthquakes, Research Report R72-54, Department of Civil Engineering, Massachusetts Institute of Technology, Cambridge, September 1972 .

Biggs, J. M., and P. H. Grace, Seismic Response of Buizdings Designed by Code for Different Earthquake Intensities, Research Report R73-7, Department of Civil Engineering, Massachusetts Institute of Technology, Cambridge, January 1973.

Blume, J. A., "Comments on Structural Response to Earthquake Motion as Related to Damage Risk," Paper presented at the U.S. Department of Commerce Meeting on Seismology and Engineering Seismology, Rockville, Maryland, January 1967.

Blume, J. A., The Spectral Matrix Method of Damage Prediction; Description and Status, Nvo-99-33, John A. Blume \& Associates, Engineers, San Francisco, California, 1968.

Blume, J. A., A Threshold Evaluation Scale Procedure for Builaings Subjected to Ground Motion, Letter Report to E. M. Douthett, Director of office of Effects Evaluation, U.S. Atomic Energy Commission, November 4, 1969. 
Blume, J. A., "An Engineering Intensity Scale for Earthquakes and Other Ground Motion," Bulzetin of the Seismological Society of America, Vol. 60, No. 1, February 1970.

Blume, J. A., and R. E. Monroe, The Spectral Matrix Method of Predicting Damage from Ground Motion, JAB-99-81, John A. Blume \& Associates Research Division, San Francisco, California, September 1971.

Control Data Corporation, SYSTEM 2000 LEVEL 2 User Information Manual, Publication No. 6074000, Revision B, 1976.

Culver, C. G., H. S. Lew, G. C. Hart, and C. W. Pinkham, Natural Hazards Evaluation of Existing Buizdings, Report No. BSS-61, U.S. Department of Commerce/National Bureau of Standards, Washington, 1975.

Czarnecki, R. M., Earthquake Damage to TalZ Buizdings, Research Report R73-8, Department of Civil Engineering, Massachusetts Institute of Technology, Cambridge, January 1973.

Gutenberg, B., and C. F. Richter, Seismicity of the Earth and Associated Phenomena, Hafner, New York, 1965.

Hafen, D., and F. C. Kintzer, Correlations Between Ground Motion and Building Damage; Engineering Intensity Scale Applied to the San Femando Earthquake of Eebruary 1971, JAB-99-111, URS/John A. Blume \& Associates, Engineers, San Francisco, California, 1977.

John A. Blume \& Associates, Engineers, "Bank of California, 15250 Ventura Boulevard, Los Angeles," in San Eemando, Califomia, Earthquake of Eebmary 9, 1971, UDC 550.319.4:62: 69(794) "1971.02.09," U.S. Department of Commerce, Leonard M. Murphy, scientific coordinator, San Francisco, 1973.

HicGuire, R. K., "Seismic Design Spectra and Mapping Procedures Using Hazard Analysis Based Directly on Oscillator Response," Earthquake Engineering and Stmuctural Dynomics, Vol. 5, No. 3, September 1977. 
Perez, V., and S. C. Schwartz, Strong-Motion Seismograph Station Listing, Tune 30, 1973, USGS Open-File Report, 1973.

Richter, C. F., EZementary Seismology, Freeman, San Francisco, 1958.

Rinehart, W., S. T. Algermissen, and M. Gibbons, Estimation of Earthquake Losses to Single Eamily Dwelzings, U. S. Department of the Interior, Geological Survey, January 1976.

Scholl, R. E., "Statistical Analysis of Low-Rise Building Damage Caused by the San Fernando Earthquake," Bulletin of the Seismological Society of America, Vol. 64, No. 1, 1974.

Schopp, K. F., and R. E. Scholl, Production of Time Dependent Response and Band Pass Fizter Spectra, JAB-99-101, John A. Blume \& Associates Research Division, San Francisco, 1972.

Schumaker, B., and R. V. Whitman, Models of Threshold Exceedance and Loss Computation of Non-Homogeneous, Spatially Distmibuted Facilities, Research Report R77-9, Department of Civil Engineering, Massachusetts Institute of Technology, Cambridge, March 1977.

Shannon \& Wilson, Inc., and Agbabian Associates, Data from SeZected Accelerograph Stations at Wilshire Boulevard, Century City, and Ventura Boulevard, Los Angeles, Califomia, NUREG/CR-0074, 1978.

Steinbrugge, K. V., F. E. McClure, and A. J. Snow, Studies in Seismicity and Earthquake Domage Statistics; Appendix A, U.S. Department of Commerce, Coast and Geodetic Survey, Washington, 1969.

Structural Engineers Association of Cal ifornia, Recommended Lateral Force Requirements and Commentary, San Francisco, California, 1975.

Trifunac, M. D., and A. G. Brady, "On the Correlation of Seismic Intensity with Peaks of Recorded Strong Ground Motion," BuZZetin of the Seismological Society of America, Vol. 65, No. 1, 1975. 
URS/John A. Blume \& Associates, Engineers, Effects Prediction Guidelines for Structures Subjected to Ground Motion, JAB-99-115, San Francisco, 1975.

Whitman, R. V., Domage Probability Matrices for Prototype Buizdings, Research Report R73-57, Department of Civil Engineering, Massachusetts Institute of Technology, Cambridge, October 1973.

Whitman, R. V., C. A. Cornell, E. H. Vanmarcke, and J. W. Reed, Methodology and Initial Damage Statistics, Research Report R72-17, Massachusetts Institute of Technology, Cambridge, March 1972.

Whitman, R. V., S. Hong, and J. W. Reed, Domage Statistics for High-Rise Buildings in the Vicinity of the San Eemando Earthquake, Research Report R73-24, Department of Civil Engineering, Massachusetts Institute of Technology, Cambridge, April 1973.

Whitman, R. V., T. S. Aziz, and E. H. Wong, Preliminary Correlations Between Earthquake Damage and Strong Ground Motion, Research Report R-77-5, Department of Civil Engineering, Massachusetts Institute of Technology, Cambridge, February 1977 .

Wilson, E. L., and H. H. Dovey, Three-Dimensional Analysis of Building Systems - TABS, EERC 72-8, Earthquake Engineering Research Center, University of California, Berkeley, 1972.

Wong, E. H., Correlations Between Earthquake Damage and Strong Ground Motion, Research Report R75-23, Department of Civil Engineering, Massachusetts Institute of Technology, Cambridge, June 1975. 
APPENDIX A

References for Data Collection 

USA 1 Murphy, L. M., Editor, "Effects on Building Structures," San Fernando, Califomia, Earthquake of Febmary 9, 1971, Vol. I, Part A, U.S. Department of Commerce, National Oceanic and Atmospheric Administration, Washington, 1973.

2 Murphy, L. M., Editor, "Effects on Building Structures," San Fernando, Califomia, Earthquake of Febmary 9, 1971, Vol. I, Part B, U.S. Department of Commerce, National Oceanic and Atmospheric Administration, Washington, 1973.

3 Murphy, L. M., Editor, "Geological and Geophysical Studies," San Femando, Califomia, Earthquake of Febmary 9, 1971, Vol. III, U.S. Department of Commerce, National Oceanic and Atmospheric Administration, Washington, 1973.

4 Steinbrugge, K. V., et al., San Femando Earthquake, February 9, 1971, Pacific Fire Rating Bureau, San Francisco, 1971.

5 Carder, D. S., Earthquake Investigations in the Westem United States 1931-1964, Publication 41-2, U.S. Department of Commerce, Coast and Geodetic Survey, Washington, 1964.

6 Bolt, B. A., et al., Geological Hazards, Springer-Verlag, New York, 1975.

7 Steinbrugge, K. V., and D. F. Moran, "An Engineering Study of the Southern California Earthquake of July 21, 1952, and Its Aftershocks," Bulletin of the Seismological Society of America, Vol. 44, No. 2B, 1954 .

8 Oakeshott, G. B., Editor, San Francisco Earthquakes of March 1957, Special Report 57, California Division of Mines, San Francisco, 1959. 
USA 9 Meehan, J. F., Structural Safety Section, Office of the State Architect, "Reconnaissance Report, Santa Barbara Earthquake, August 13, 1978," Earthquake Engineering Research Institute Newsletter, Vol. 12, No. 5, September 1978 .

10 Wood, F. J., The Prince William Sound, Alaska, Earthquake of 1964 and Aftershocks, Vol. II, Part A, U.S. Department of Commerce, Environmental Science Services Administration, Coast and Geodetic Survey Publication 10-3, Washington, 1967.

11 Berg, G. V., and J. L. Stratta, Anchorage and the Alaska Earthquake of March 27, 1964, American Iron and Steel Institute, Washington, 1964 .

12 Steinbrugge, K. V., W. K. Cloud, and N. H. Scott, The Santa Rosa, Califomia, Earthquakes of October 1, 1969, U.S. Department of Commerce, Environmental Science Services Administration, Coast and Geodetic Survey, Maryland, 1970.

13 Nielsen, N. N., et al., The Honom, Hawaii, Earthquake, National Research Council, National Academy of Sciences, Washington, 1977.

14 Freeman, J. R., Earthquake Damage and Earthquake Insurance, McGrawHill, New York, 1932.

15 Edwards, H. H., Author-Chairman, Earthquake Committee, American Society of Civil Engineers, Seattle Section, Discussion of Damage Caused by the Pacific Northwest Earthquake of April 13, 1949, Seattle, 1950.

16 Steinbrugge, K. V., et al., The Puget Sound, Washington, Earthquake of Apriz 29, 1965, U.S. Department of Commerce, Coast and Geodetic Survey, Washington, 1965.

17 Lawson, A. C., Chairman, State Earthquake Investigation Commission, The Califomia Earthquake of April 18, 1906, Carnegie Institution, Washington, 1908 . 
USA 18 Board of Supervisors of San Francisco, Excerpts from San Francisco Municipal Reports, Neal Publishing Co., San Francisco, 1908.

19 Gilbert, G. K., et al., The San Francisco Earthquake and Fire of Aprit 18, 1906, U.S. Department of the Interior, U.S. Geological Survey, Washington, 1907.

20 Himmelwright, A. L. A., The San Francisco Earthquake and Fire, The Roebling Construction Co., New York, 1906.

21 Ayres, J.M., et al., A Report on Non-Stmctural Damage to Buildings: Alaska Earthquake, March 27, 1964, Consulting Engineers Association of California, Burlingame, 1967.

22 Hansen, W. R., The Alaska Earthquake, March 27, 1964 - Effects on Communities, U.S. Department of the Interior, Geological Survey Professional Paper 542-A, Washington, 1965.

23 Degenkolb, H. J., "Structural Observations of the Kern County Earthquake, Transactions, American Society of Civil Engineers, Vol. 120, Paper No. 2777, New York, 1955.

24 California Institute of Steel Construction, Southern California Division, Why Take a Chance?, Los Angeles, 1925.

25 Alvarez, A. C., The Santa Barbara Earthquake of June 29, 1925 Effects on Buizdings of Various Types, University of California Press, Berkeley, 1925.

26 Davis, R. E., Effect of Southem Califomia Earthquake Upon Buildings of Unit Masonxy Constmuction, American Society for Testing Materials, Berkeley, 1933.

27 National Board of Fire Underwriters, Committee on Fire Prevention and Engineering Standards, Report on the Southem Califormia Earthquake of March 10, 1933, New York, 1933. 
USA 28 Gutenberg, B., and C. F. Richter, Seismicity of the Earth and Associated Phenomena, Hafner Publishing Co., New York, 1965.

29 Harding, S. T., et al., The Parkfield, Califomia, Earthquake of June 27, 1966, U.S. Department of Commerce, Environmental Science Services Administration, Coast and Geodetic Survey, Washington, 1966.

30 National Center for Earthquake Research, The Parkfield-Cholome, Califormia, Earthquakes of June-August 1966 - Surface Geologic Effects, Water Resources Aspects, and Preliminary Seismic Data, U.S Department of the Interior, Geological Survey Professional Paper 579, Washington, 1967 .

31 Cloud, W. K., and C. F. Knudson, The Eairbanks, AZaska, Earthquakes of June 21, 1967, U.S. Department of Commerce, Environmental Science Services Administration, Coast and Geodetic Survey, Washington, 1967.

32 Seismological Field Survey, U.S. Department of Commerce, Environmental Science Services Administration, Coast and Geodetic Survey, and Earthquake Engineering Research Laboratory, Division of Engineering and Applied Science, California Institute of Technology, StrongMotion Instrumental Data on the Borrego Mountain Earthquake of 9 Aprit 1968, Pasadena, 1968.

33 Hileman, J. A., et al., Seismicity of the Southem Califomia Region 1 January 1932 to 31 December 1972, Seismological Laboratory, California Institute of Technology, Pasadena, 1973.

34 Seismological Society of America, "Seismological Notes," Buzzetin of the Seismological Society of America, Vol. 63, No. 5, 1973.

35 Seismological Society of America, "Seismological Notes," BuZletin of the Seismological Society of America, Vol. 39, No. 3, 1949.

36 Seismological Society of America, "Seismological Notes," Bulletin of the Seismological Society of America, Vol. 45, No. 1, 1955. 
USA 37 Seismological Society of America, "Seismological Notes," BuZZetin of the Seismological Society of America, Vol. 46, No. 1, 1956.

38 Blume, J. A., San Francisco Seismic Safety Investigation, URS/John A. Blume E Associates, Engineers, San Francisco, 1974.

39 Structural Engineers Association of Northern California, Lateral Force Committee, 1952 Earthquakes of Kem County, Califomia, San Francisco, 1955.

40 U.S. Geological Survey, U.S. Department of the Interior, A Study of Earthquake Losses in the Puget Sound, Washington, Area, Open-File Report 75-375, Washington, 1975.

41 Philbrick, R. A., and G. N. Owen, Reconnaissance Report - August 13, 1978 Santa Barbara Earthquake, URS/John A. Blume \& Associates, Engineers, San Francisco, 1978.

42 Takahashi, S. K., and W. E. Schniete, Preliminary Investigation of Stmetural Damage From Point Mugu, Califomia Earthquake of Febmary 21, 1973, Naval Civil Engineering Laboratory, Port Hueneme, 1973.

43 Brazee, R. J., Editor, Catalog of Strong-Motion Seismograph Stations and Records, U.S. Department of Commerce, National Oceanic and Atmospheric Administration, Environmental Data Service, National Geophysical and Solar-Terrestrial Data Center, Boulder, 1974.

44 Oakeshott, G. B., Editor, Earthquakes in Kern County Califomia During 1952, Bulletin 171, California Division of Mines, San Francisco, 1955 .

45 Shannon \& Wilson, Inc., and Agbabian Associates, Geotechnical and Strong Motion Earthquake Data From U.S. Accelerograph Stations, NUREG-0029, Vol. 2, NRC-6A, U.S. Nuclear Regulatory Commission, Washington, 1978 . 
USA 46 Agbabian Associates, Comelation of Ground Response Spectra With Modified Mercalli Site Intensity, Energy Research and Development Administration, Washington, 1977.

47 Wiegel, R. L., Coordinating Editor, Earthquake Engineering, PrenticeHall, Inc., Engelwood Cliffs, New Jersey, 1970.

48 Earthquake Engineering Research Laboratory, California Institute of Technology, Strong Motion Earthquake AcceZerograms, Vol. 2 and 3 , Pasadena, 1971-1976.

49 Boore, D. B., et al., Estimation of Ground Motion Parameters, Open File Report 78-509, U.S. Department of the Interior, Geological Survey, Washington, 1978 .

50 U.S. Department of the Interior, Geological Survey, Westem Hemisphere Strong-Motion AcceZerograph Station List: 1976, Open File Report No. 77-374, Washington, 1977.

51 Trifunac, M. D., and A. G. Brady, "On the Correlation of Seismic Intensity Scales with the Peaks of Recorded Strong Ground Motion," Bulletin of the Seismological Society of America, Vol. 65, No. 1, 1975.

52 Trifunac, M. D., and A. G. Brady, "A Study on the Duration of Strong Earthquake Ground Motion," Bulzetin of the Seismological Society of America, Vol. 65, No. 3, 1975.

53 Trifunac, M. D., "Preliminary Empirical Model for Scaling Fourier Amplitude Spectra of Strong Ground Acceleration in Terms of Earthquake Magnitude, Source-to-Station Distance, and Recording Site Conditions," Bulzetin of the Seismological Society of America, Vol. 66, No. 4, 1976 .

54 Duke, C. M., et al., Subsurface Site Conditions and Geology in the San Fermando Earthquake Area, UCLA-ENG-7206, University of California, Los Angeles, 1971. 
USA 55 Duke, C. M., et al., Effects of Site Classification and Distance on Instmumental Indices in the San Femando Earthquake, UCLA-ENG-7247, University of California, Los Angeles, 1972.

56 Campbell, K. W., et al., Shear Velocities and Near-Surface Geologies at Accelerograph Sites that Recorded the San Eemando Earthquake, UCLA-ENG-7653, University of California, Los Angeles, 1976.

57 Chang, F. K., An Empirical Interpretation of the Effects of Topography on Ground Motion of the San Eemando, Califomia, Earthquake, 9 January 1971, Miscellaneous Paper S-76-1, Office, Chief of Engineers, U.S. Army, Washington, 1976.

58 Hansen, W. R., et al., Geotechnical Data Compilation for Selected Strong-Motion Seismograph Sites in Califomia, Woodward-Lundgren $\varepsilon$ Associates, Oakland, California, 1973.

59 Committee on the Alaska Earthquake, Division of Earth Sciences, National Research Council, The Great Alaska Earthquake of 1964: Engineering, National Academy of Sciences, Washington, 1973.

60 Gates, W. E., "Building Period Relations," unpublished manuscript, 1976.

61 U.S. Geological Survey, Seismic Engineering Program Report: October December 1974, Geological Survey Circular 713, Washington, 1974.

62 Hafen, D., and F. C. Kintzer, Correlations Between Ground Motion and Building Domage: Engineering Intensity Scale Applied to the San Fernando Earthquake of Eebmary 1971, URS/John A. Blume \& Associates, Engineers, San Francisco, 1977.

63 Whitman, R. V., et al., Damage Statistics for High-Rise Buizaings in the Vicinity of the San Fermando Earthquake, Report No. 7, Publication No. R73-24, Massachusetts Institute of Technology, Cambridge, 1973. 
USA 64 Whitman, R. V., Damage Probability Matrices for Prototype Buizdings, Report No. 8, Publication No. R73-57, Massachusetts Institute of Technology, Cambridge, 1973.

65 Wong, E. H., Correlations Between Earthquake Damage and Strong Ground Motion, Report No. 19, Publication No. R75-23, Massachusetts Institute of Technology, Cambridge, 1975.

66 Porter, L. D., Compization of Strong-Motion Records Recovered from the Santa Barbara Earthquake of 13 August 1978, Preliminary Report 22, California Division of Mines and Geology, Sacramento, 1978.

67 Whitman, R. V., et al., 1964 AZaskan Earthquake Talz Building Damage Review, Internal Study Report No. 11, Massachusetts Institute of Technology, Cambridge, 1972.

68 Hong, S. T., and J. W. Reed, 1965 Puget Sound, Washington, Earthquake Tall Building Damage Review, Internal Study Report No. 23, Massachusetts Institute of Technology, Cambridge, 1972.

69 Hong, S. T., and J. W. Reed, 1957 San Erancisco Earthquake TaZl Buizding Domage Review, Internal Study Report No. 22, Massachusetts Institute of Technology, Cambridge, 1972.

70 Reuter, H. R., Colzapse of the Four Seasons Apartment Buizding, Technical Report No. 4, Western Concrete Structures Co., Inc., Gardena, 1965.

71 Algermissen, S. T., et al., A Study of Earthquake Losses in the Los Angeles, Califomia, Area, U.S. Department of Commerce, National Oceanic and Atmospheric Administration, Environmental Research Laboratories, Washington, 1973.

72 Duke, C. M., and D. J. Leeds, Site Characteristics of Southem Califomia Strong-Motion Earthquake Stations, Report 62-55, Department of Engineering, University of California, Los Angeles, 1962; reprinted by the California Division of Mines and Geology, Special Publication 38,1972 . 
USA 73 Meehan, J. F., Office of the State Architect, "Reconnaissance Report, Santa Barbara Earthquake, August 13, 1978, "Earthquake Engineering Research Institute Newsletter, Vol. 12, No. 5, 1978.

74 Porter, L. D., et al., Processed Data from the Partial Strong-Motion Records of the Santa Barbara Earthquake of 13 August 1978, Preliminary Report 23, California Division of Mines and Geology, Sacramento, 1979.

75 U.S. Geological Survey, "Preliminary Information from Recent Earthquakes," Strong-Motion Information Retrieval System: Users Manual, Open-File Report 79-289, Menlo Park, 1973. 
MEXICO (MEX)

MEX 1 Herrera, I., "Foundation Failures During the Coatzacoalcos (Mexico) Earthquake of August 26, 1959," Ingeniería, December 1959.

2 Rosenblueth, E., "The Earthquake of 28 July 1957 in Mexico City," Proceedings of the and World Conference on Earthquake Engineering, Vol. 1, Japan, 1960.

3 Herrera, I., E. Rosenblueth, and 0. Rascon, "Earthquake Spectrum Prediction for the Valley of Mexico," Proceedings on the 3rd World Conference on Earthquake Engineering, New Zealand, 1965.

4 Binder, R. W., "The Acapulco, Mexico, Earthquakes of May 11 and 19, 1962," Proceedings of the 3rd World Conference on Earthquake Engineering, Vol. 3, New Zealand, 1965.

5 Esteva, L., 0. Rascon, and A. Gutierrez, "Lessons from Recent Earthquakes in Latin America," Proceedings of the 4th World Conference on Earthquake Engineering, chile, 1969.

6 Esteva, L., and E. Rosenblueth, "Espectros de temblores a distancias moderadas y grandes," Boletin, Sociedad Mexicana de Ingenieria Sismica, Vol. 2, No. 1, Mexico, 1964.

7 Meehan, J. F., "Reconnaissance Report of the Veracruz, Mexico Earthquake of August 28, 1973," Buzletin of the Seismological Society of America, Vol. 64, No. 6, 1974.

8 Irvine, H. M., Veracruz Earthquake of 28 August 1973, EERL 73-06, Earthquake Engineering Research Laboratory, California Institute of Technology, Pasadena, October 1973. 
MEX 9 Bustamante, J. I., J. Lopez, and M. Gonzalez, Espectros del sismo del 9 de diciembre, 1965, en Acapulco, El Infiemilto y México, Instituto de Ingeniería, Universidad Nacional Autónoma de México, Reporte $140,1967$.

10 Esteva, L., "Los temblores de mayo de 1962 en Acapulco," Boletin, Sociedad Mexicana de Ingeniería Sísmica, Vol. 1, No. 2, Mexico, 1963.

11 Figueroa, J., "Determinación de las velocidades de propagación y constantes elasticas por prospección sísmica," Boletín, Sociedad Mexicana de Ingeniería Sísmica, Vol. 2, No. 1, Mexico, 1964.

12 Universidad Nacional Autónoma de México, Escuela Nacional de Ingeniería, "The Effects of the Earthquake of July 28, 1957 and the Resulting Revision of the Criteria for the Seismic Design of Structures," from the Symposium held at the Escuela Nacional de Ingeniería, Ciudad Universitaria, Mexico City, August 27, 1957, Ingenieria, January 1958.

13 John A. Blume \& Associates, Engineers, Stmuctural Effects in Mexico City from the August 2, 1968 Earthquake, Preliminary Report, October 1969.

14 Thornley, J. H., and P. Albin, Jr., "Mexico City Earthquake Damage Examined," Civir Engineering, ASCE, Vol. 27, No. 10, 1957.

MANAGUA, NICARAGUA (MNG)

MNG 1 Earthquake Engineering Research Institute, Managua, Nicaragua, Earthquake of December 23, 1972, San Francisco, May 1973.

2 Leeds, D. J., "Destructive Earthquakes of Nicaragua," Managua, Nicaragua, Earthquake of December 23, 1972, Conference Proceedings, Vol. 1 and 2, Earthquake Engineering Research Institute, San Francisco, 1973. 
MNG 3 Dewey, J.W., S. T. Algermissen, and C. Langer, "The Managua Earthquake of 23 December 1972: Location, Focal Mechanism, Aftershocks, and Relationship to Recent Seismicity of Nicaragua," Managua, Nicaragua, Earthquake of December 23, 1972, Conference Proceedings, Vol. 1 and 2, Earthquake Engineering Research Institute, San Francisco, 1973.

4 Pereira, E. H., and P. J. Creegan, "Statistical Damage Report: Managua," Managua, Nicaragua, Earthquake of December 23, 1972, Conference Proceedings, Vol. 1 and 2, Earthquake Engineering Research Institute, San Francisco, 1973.

5 Hansen, F. A., and V. M. Chávez, "Isoseismal Maps of the Managua December 23, 1972 Earthquake," Managua, Nicaragua, Earthquake of December 23, 1972, Conference Proceedings, Vol. 1 and 2, Earthquake Engineering Research Institute, San Francisco, 1973.

6 Knudson, C. F., and F. A. Hansen, "Accelerograph and Seismoscope Records from Managua, Nicaragua Earthquakes," Managua, Nicaragua, Earthquake of December 23, 1972, Conference Proceedings, Vol. 1 and 2, Earthquake Engineering Research Institute, San Francisco, 1973.

7 Earthquake Engineering Research Institute, Managua, Nicaragua, Earthquake of December 23, 1972, Conference Proceedings, Vol. 1 and 2, San Francisco, 1973.

8 Pérez, V., 'Time-Dependent Spectral Analysis of Four Managua Earthquake Records," Managua, Nicaragua, Earthquake of December 23, 1972 , Conference Proceedings, Vol. 1 and 2, Earthquake Engineering Research Institute, San Francisco, 1973.

9 Valera, J. E., "Soil Conditions and Local Soil Effects During the Managua Earthquake of December 23, 1972," Managua, Nicaragua, Earthquake of December 23, 1972, Conference Proceedings, Vol. 1 and 2, Earthquake Engineering Research Institute, San Francisco, 1973. 
10 Facioli, E., E. V. Santoyo, and J. L. T. León, "Microzonation Criteria and Seismic Response Studies for the City of Managua," Managua, Nicaragua, Earthquake of December 23, 1972, Conference Proceedings, Vol. 1 and 2, Earthquake Engineering Research Institute, San Francisco, 1973 .

11 Hays, W. W., and K. W. King, "Use of Managua Earthquake Aftershock Data to Estimate Main Shock Power Spectra," Managua, Nicaragua, Earthquake of December 23, 1972, Conference Proceedings, Vol. 1 and 2, Earthquake Engineering Research Institute, San Francisco, 1973.

12 Teran, J. F., "Historical Content of Building Forms in Nicaragua," Managua, Nicaragua, Earthquake of December 23, 1972, Conference Proceedings, Vol. 1 and 2, Earthquake Engineering Research Institute, San Francisco, 1973.

13 Wyllie, L. A. J., "Performance of the Banco Central Building," Managua, Nicaragua, Earthquake of December 23, 1972, Conference Proceedings, Vol. 1 and 2, Earthquake Engineering Research Institute, San Francisco, 1973 .

14 T. Y. Lin International, John A. Blume \& Associates, Engineers, and H. C. Shah, "An Evaluation of Structural Behavior as a Result of the December 23, 1972, Earthquake: Teatro Nacional Rubén Darío; Edificio ENALUF; Banco Central de Nicaragua," Managua, Nicaragua, Earthquake of December 23, 1972, Conference Proceedings, Vol. 1 and 2, Earthquake Engineering Research Institute, San Francisco, 1973.

15 Shah, H. C., J.P. Nicoletti, and F. Kulka, "Post Earthquake Dynamic Measurements of Four Structures in Managua," Managua, Nicaragua, Earthquake of December 23, 1972, Conference Proceedings, Vol. 1 and 2, Earthquake Engineering Research Institute, San Francisco, 1973.

16 Rojahn, C., "Analysis of Banco de América and Banco Central Post Earthquake Ambient Vibration Observation," Managua, Nicaragua, Earthquake of December 23, 1972, Conference Proceedings, Vol. 1 and 2, Earthquake Engineering Research Institute, San Francisco, 1973. 
MNG 17 Selna, L. G., and M. D. Cho, "Banco de América, Managua: A HighRise Shear Wall Building Withstands a Strong Earthquake," Managua, Nicaragua, Earthquake of December 23, 1972, Conference Proceedings, Vol. 1 and 2, Earthquake Engineering Research Institute, San Francisco, 1973 .

18 McLean, R. S., "Three Reinforced Concrete Frame Buildings, Managua Earthquake, December 1972,"Managua, Nicaragua, Earthquake of December 23, 1972, Conference Proceedings, Vol. 1 and 2, Earthquake Engineering Research Institute, San Francisco, 1973.

19 International Conference of Building Officials, Uniform Building Code, Pasadena, 1964.

20 Sozen, M. A., and A. Shibata, "An Evaluation of the Banco de América Building, Managua, Nicaragua," Managua, Nicaragua, Earthquake of December 23, 1972, Conference Proceedings, Vol. 1 and 2, Earthquake Engineering Research Institute, San Francisco, 1973.

21 Aktan, H. M., and R. D. Hanson, "Dynamic Behavior of Hotel Managua Intercontinental in the Managua Earthquake of December 23, 1972, Managua, Nicaragua, Earthquake of December 23, 1972, Conference Proceedings, Vol. 1 and 2, Earthquake Engineering Research Institute, San Francisco, 1973.

22 Hanson, R. D., and S. C. Goel, "Behavior of the ENALUF Office Building in the Managua Earthquake of December 23, 1972,"Managua, Nicaragua, Earthqukae of December 23, 1972, Conference Proceedings, Vol. 1 and 2, Earthquake Engineering Research Institute, San Francisco, 1973.

23 Nicoletti, J. P., and F. Kulka, "Response of the ENALUF Building to the Managua Earthquake," Managua, Nicaragua, Earthquake of December 23, 1972, Conference Proceedings, Vol. 1 and 2, Earthquake Engineering Research Institute, San Francisco, 1973. 
24 Earthquake Engineering Research Institute Investigative Team I, Survey of Damages and Earthquake Performance of Managua Buildings," Managua, Nicaragua, Earthquake of December 23, 1972, Conference Proceedings, Vol. 1 and 2, Earthquake Engineering Research Institute, San Francisco, 1973.

VENEZUELA (VNZ)

VNZ 1 Hanson, R. D., and H. J. Degenkolb, The VenezueZa Earthquake of July 29, 1967, American Iron \& Steel Institute, New York, 1969.

2 Skinner, R. I., "Damage Mechanisms and Design Lessons from Caracas," Proceedings of the 4th World Conference on Earthquake Engineering, Chile, 1969.

3 Whitman, R. V., Effect of Soil Conditions Upon Damage to Structures, Caracas Earthquake of 29 July 1967, Presidential Commission for Study of the Earthquake, Cambridge, 1968.

4 Esteva, L., R. Diaz de Cossio, and J. Elorduy, "El temblor de Caracas, 29 de julio de 1967," Ingeniería, Vol. 38, No. 3, Mexico, 1968.

5 Skinner, R. I., "Engineering Study of Caracas Earthquake, Venezuela, 29 July 1967," Buzletin of the New Zealand Department of Seience and Industrial Researeh, Vol. 191, 1968.

6 Seed, H. B., I. M. Idriss, and H. Dezfulian, Relationships Between Soil Conditions and Building Damage in the Caracas Earthquake of July 29, 1967, Report No. EERC 70-2, Earthquake Engineering Research Center, University of California, Berkeley, February 1970.

7 Sozen, M. A., P. C. Jennings, R. B. Matthiesen, G. W. Housner, and N. M. Newmark, Engineering Report on the Caracas Earthquake of 29 Juzy 1967, prepared for the Committee on Earthquake Engineering Research, National Academy of Engineering, National Academy of Sciences, Washington, 1968. 
VNZ 8 Ministerio de Obras Publicas, "Plano de inmuebles afectados por el sismo del 29-7-67," joint information of different Minesterio de Obras Publicas and other engineering public institutions on the basis of Caracas, Venezuela 1:5.000 plan, Caracas, 1967.

9 Instituto de Materiales y Modelos Estructurales, "Mediciones y ensayos practicados sobre muestras obtenidas de escombros de cinco edificios destruídos por el sismo ocurrido en Caracas el 29-7-67," Informe Especial, Facultad de Ingeniería, Universidad Central de Venezuela, Caracas, 1967.

10 Fintel, M., J. M. Nieves, H. J. Jobse, J. E. Armhein, and P. G. Griffin, The Behavior of Reinforced Concrete Structures in the Caracas, Venezuela, Earthquake of July 29, 1967, Preliminary Report, Portland Cement Association, Skokie, 111 inois, September 1967.

11 Steinbrugge, K. V., and L. S. Cluff, The Caracas, Venezuela Earthquake of July 29, 1967, Mineral Information Service, San Francisco, January 1968.

12 Mahin, S. A., and V. V. Bertero, "Nonlinear Seismic Response Evaluation: Charaima Building," Joumal of the Stmctural Division, ASCE, Vol. 100, No. ST6, 1974.

13 Seed, H. B., I. M. Idriss, and H. Dezfulian, ReZationships Between Soil Conditions and Buizding Damage in the Caracas Earthquake of July 29, 1967, Report No. EERC 70-2, Earthquake Engineering Research Center, University of California, Berkeley, February 1970.

PERU (PER)

PER 1 Lee, K. L. and E. J. Monge, "Effect of Soil Conditions on Damage in the Peru Earthquake of October 17, 1966," Bulletin of the Seismological Society of America, Vol. 58, No. 3, 1968.

2 Cluff, L. S., "Peru Earthquake of May 31, 1970, Engineering Geology observations," Buzletin of the Seismological Society of America, Vol. 61, No. 3, 1971. 
PER 3 Meehan, J. F., "Performance of School Buildings in the Peru Earthquake of May 31, 1970," Buzletin of the Seismological Society of America, Vol. 61, No. 3, 1971.

4 Berg, G. V., and L. R. Husid, "Structural Effects of the Peru Earthquake," Bulletin of the Seismological Society of America, Vol. 61, No. 3,1971 .

5 Espinosa, A. F., R. Husid, S. T. Algermissen, and J. de las Casas, "The Lima Earthquake of October 3, 1974: Intensity Distribution," Bulletin of the Seismological Society of America, Vol. 67, No. 5, 1977.

6 Husid, R., A. F. Espinosa, and J. de las Casas, "The Lima Earthquake of October 3, 1974: Damage Distribution," Bulletin of the Seismological Society of America, Vol. 67, No. 5, 1977.

\section{CHILE (CHI)}

CHI 1 Lomnitz, C., "A Study of Maipo Valley Earthquakes of September 4, 1958," Proceedings of the 2nd Worta Conference on Earthquake Engineering, Japan, 1960.

2 Flores, A. R., S. Arias, V. Jenschke, and L. A. Rosenberg, "Engineering Aspects of the Earthquakes in the Maipo Valley, Chile, in 1958," Proceedings of the 2nd World Conference on Earthquake Engineering, Vol. 1, Japan, 1960.

3 Earthquake Engineering Research Institute, "An Engineering Report on the Chilean Earthquakes of May 1960," Buzletin of the Seismological Society of America, Vol. 53, No. 4, 1963.

4 Duke, C. M., and D. J. Leeds, "Response of Soils, Foundations, and Earth Structures to the Chilean Earthquakes of 1960," Buzletin of the Seismological Society of America, Vol. 53, No. 4, 1963. 
CHI 5 Lastrico, R. M., and J. Monge, "Engineering Aspects of the July 8, 1971 Earthquake in Central Chile," Proceedings of the 5th World Conference on Earthquake Engineering, Rome, 1973.

6 Hidalgo, P., and J. Vasquez, "Analys is of the Behavior of the Puerto Montt, Banco Central de Chile Structure," Proceedings of the 3rd World Conference on Earthquake Engineering, Vol. 3, New Zealand, 1965.

7 Rojas, H., "Analysis of the Damage Caused by the 1960 Earthquakes in a Building of the Chiprodal Factory in Llanquihue, Chile," Proceedings of the $3 r d$ World Conference on Earthquake Engineering, Vol. 3, New Zealand, 1965.

8 Eisenberg, A., R. Husid, and J. E. Luco, "A Preliminary Report The July 8, 1971 Chilean Earthquake," Buzletin of the Seismological Society of America, Vol. 62, No. 1, 1972.

\section{GUATEMALA (GUA)}

GUA 1 Espinosa, A. F., Intensity Distribution of the Guatemala Earthquake," Earthquake Information Bulletin, U.S. Geological Survey, Vol. 9, No. 2, 1977.

2 Harkins, J. P., personal communication.

3 Instituto de Fomento de Hipopecas Aseguradas and Centro de Estudios Mesoamericanos de Technología Apropiada, Proceedings of the International Symposium on the Eebruary 4, 1976 Guatematan Earthquake and the Reconstruction Process, Vol. 1 and 2, 1978.

EL SALVADOR (SAS)

SAS 1 Rosenblueth, E. and J. Prince, "El temblor de San Salvador, 3 de mayo de 1965," Ingeniería Sísmica, Vol. 3, No. 2, Mexico, 1965. 
ANTIGUA (ANT)

ANT 1 Tomblin, J. F., and W. P. Aspinall, "Reconnaissance Report of the Antigua, West Indies, Earthquake of October 8, 1974, "Buzletin of the Seismological Society of America, Vol. 65, No. 6, 1975. 
REFERENCES FOR DATA COLLECTION - EUROPE AND THE MEDITERRANEAN (EUR)

EUR 1 American Iron and Steel Institute, Earthquakes, New York, 1975.

2 Stratta, J. L., and L. A. Wyllie, Jr., PreZiminamy Reconnaissance Report on the Italian Earthquake of May 6, 1976 , Earthquake Engineering Research Institute, Vol. 10, No. 4, San Francisco, 1976.

3 Leeds, D. J., Earthquake in Romania, A Preliminary Report to EERI, Earthquake Engineering Research Institute, Vol. 11, No. 3B, San Francisco, 1977.

4 L'Industria Italiana del Cemento, The Earthquake in Eriuzi, May 6, 1976, Luglio, August 1976

5 CNEN-ENEL Commission on Seismic Problems Associated with the Installation of Nuclear Plants, Contribution to the Study of the Friuli Earthquake, November 1976.

6 Penzien, J., and R. Hanson, The Gediz, Turkey Earthquake of 1970 , National Academy of Sciences for the National Academy of Engineering, Washington, 1970 .

7 Sozen, M. A., Stmetural Damage Caused by the Skopje Earthquake of 1963, Civil Engineering Studies, Structural Research Series, No. 279, University of 111 inois, Urbana, 1964.

8 Tasdemiroğlu, M., "The Gediz Earthquake in Western Anatolia, Turkey," Bulletin of the Seismological Society of America, Vol. 61, No. 6, 1971 .

9 Arioğlu, E., and K. Anadol, "The Gediz Earthquake, March 1970 (Turkey),"Mimartik, Vol. 9, No. 90/91, 1971. 
EUR 10 Despeyroux, J., "The Agadir Earthquake of February 29, 1960: Behavior of Modern Buildings During the Earthquake," Proceedings of the 2nd World Conference on Earthquake Engineering, Vol. 1, Tokyo, 1960.

11 Blume, J. A., PreZiminary Report: SaZonica, Greece Earthquake, Earthquake Engineering Research Institute, Vol. 12, No. 4, San Francisco, 1978 .

12 Psycharis, 1., The Salonica (Thessaloniki) Earthquake of June 20, 1978, Earthquake Engineering Research Laboratory, California Institute of Technology, Pasadena, October, 1978.

13 Fintel, M., "Report of the Earthquakes of May 24 and June 20, 1978, Solanika, Greece," Joumal of the American Concrete Institute, October 1978 .

14 Carydis, P., Preliminary Report on the Thessaloniki Earthquakes of May 24 and June 20, 1978, Greece National Technical University, Athens. Prepared for publication by the Earthquake Engineering Research Institute, San Francisco, 1978.

15 Mandrescu, N., "The Vrancea Earthquake of March 4, 1977 and the Seismic Microzonation of Bucharest," Proceedings of the 2nd International Conference on Microzonation, Vol. 1, November 1978.

16 Sozen, M. A., Structural Damage Caused by the Skopje Earthquake of 1963, Civil Engineering Studies, Structural Research Series, No. 279, University of 111 inois, Urbana, 1964.

17 Fattal, G., E. Simiu, and C. Culver, Observations on the Behavion of Buizdings in the Romania Earthquake of March 4, 1977, NBS Special Publication 490, National Bureau of Standards, U.S. Department of Commerce, September 1977. 
PAC 1 Kawasumi, H., General Report on the Niigata Earthquake of 1964 , Tokyo Electrical Engineering Press, Tokyo, 1968.

2 The National Research Center for Disaster Prevention Science and Technology, Strong Motion Earthquake Records in Japan, Japan, Vol. 12,1971 - Vol. 21, 1976.

3 Suzuki, Z., General Report on the Tokachi-oki Earthauake of 1968, Keigaku Publishing Co., Ltd., Japan, 1971.

4 Ehlers, J.H., Reconstmetion and Development of the Tokyo-Yokohoma District, U.S. Department of Commerce, Washington, 1928.

5 Office of the Engineer General Headquarters, Far East Command, Geological Surveys Branch, The Eukui Earthquake, Hokuriku Region, Japan, Vol. 1 and 2, Tokyo, 1949.

6 Imamura, A., "Preliminary Note on the Great Earthquake of Southeastern Japan on September 1, 1923," Buzletin of the Seismological Society of America, Vol. 14, No. 2, 1924.

7 Hadley, H. M., "Earthquake-Proof Building Construction As Revealed by the Japanese Earthquake," Bulletin of the Seismological Society of America, Vol. 14, No. 1, 1924.

8 Richter, C. F., EZementary Seismology, W. H. Freeman and Company, San Francisco, 1958.

9 Jaggar, T. A., "The Yokohama-Tokyo Earthquake of September 1, 1923," Bulletin of the Seismological Society of America, Vol. 13, No. 4, 1923.

10 Seismological Society of America, "Seismological Notes," Buzletin of the Seismological Society of America, Vol. 13, No. 3, 1923. 
PAC 11 Freeman, J. R., Earthquake Damage and Earthquake Insurance, McGrawHill, New York, 1932.

12 Stechschulte, U. C., "Japanese Earthquake of March 29, 1928 and the Problem of Depth of Focus, "Bulzetin of the Seismological Society of America, Vol. 22, No. 2, 1932.

13 Hodgson, E. A., "The P-Curve and the S-Curve Resulting from a Study of the Tango Earthquake, Japan, March 7, 1927," BulZetin of the Seismological Society of America, Vol. 22, No. 1, 1932.

14 National Research Center for Disaster Prevention Science and Technology Agency, Reports of the Niigata Earthauake from the Viewpoint of Disaster Prevention (Part 1), Tokyo, March 1966.

15 Ohtani, K., and T. Kubota, "Damage of Structures Due to the 1974 Izuhanto-Oki Earthquake," Proceedings of the 6th World Conference on Earthquake Engineering, New Delhi, Vol. 1, 1977.

16 Yamada, M. and H. Kawamura, "Damaged and Nondamaged Re inforced Concrete Modern Buildings at the Oita Earthquake, April 21, 1975," Proceedings of the 6th World Conference on Earthquake Engineering, New Delhi, Vol. 1, 1977.

17 Tomii, M. and K. Yoshimura, "Damage to a Reinforced Concrete Hotel Building Due to the Oita Earthquake of April 21, 1975," Proceedings of the 6th World Conference on Earthquake Engineering, New Delhi, Vol. $1,1977$.

18 Public Works Research Institute, Preliminary Report of Investigations on the Relief and Rehabilitation in the Izu-Ohsima Kinkai Earthquake of 1978 , No. 344, Tokyo, February 1978.

19 Brady, A. G., Strong Motion Earthquake Records, United States Geological Survey, Menlo Park, 1978. 
20 Wentworth, C. W., Off-Miyagi Earthquake of June 12, 1978: Seismicity and Geologic Settings, United States Geological Survey, Menlo Park, 1978.

21 URS/John A. Blume \& Associates, Engineers, Builaing Response Data for the Off-Miyagi Earthquakes of Eebmary 20, 1978 and June 12, 1978, Project File 7817-01, San Francisco, October 1978.

22 Stratta, James L., et al., Reconnaissance Report, Mindanao, Philippines Earthquake, August 17, 1976, Earthquake Engineering Research Institute, San Francisco, August 1977.

23 Bureau of Statistics, Office of the Prime Minister, Japan Statistical Yearbook: 1976, Tokyo, 1976.

24 "Strong Quakes Rock Northern Japan," The Japan Times, Tokyo, May $17,1968$.

25 "Strong Quake Rocks Northern Japan," The Japan Times, Tokyo, January 22, 1970.

26 "South Kyushu Rocked by Strong Earthquake," The Japan Times, Tokyo, July $27,1970$.

27 "Tohuku Area Quake Hits JNR Line," The Japan Times, Tokyo, October $17,1970$.

28 "Strong Earthquake Jolts East Coast of Northern Japan," The Japan Times, Tokyo, June 19, 1973.

29 "Quake Rocks Kyushu, Shikoku: 10 Injured," The Japan Times, Tokyo, April 22, 1975.

30 Tada, T., "Fault Model and Crustal Movement of the 1973 Nemuro-0ki Earthquake," Zisin, Joumal of the Seismological Society of Japan, Vol. 27, No. 2, 1974 . 
PAC 31 Yokouchi, T., et al., "Studies on the Earthquake off the Nemuro Peninsula, June 17, 1973," General Report on the Earthquake off the Nemuro Peninsula, June 17, 1973, Japan, Ministry of Education, Tokyo, March 1974.

32 "Seismological Notes," Bulletin of the Seismological Society of America, Vol. 14, No. 1, 1924.

33 Bureau of Social Affairs, Home Office, The Great Earthquake of 1923 in Japan, Japan, 1926.

34 Kanamori, H., "Faulting of the Great Kanto Earthquake of 1923 as Revealed by Seismological Data," Bulzetin of the Earthquake Research Institute, Vol. 49, Tokyo, 1971.

35 Yamasaki, N., and F. Tada, "The Oku-Tango Earthquake of 1927," Bulletin of the Earthquake Research Institute, Vol. 4, Tokyo, 1928.

36 Imamura, A., "On the Destructive Tango Earthquake of March 7, 1927," Bulletin of the Earthquake Research Institute, Vol. 4, Tokyo, 1928.

37 Imamura, A., "Seismometric Study of the Recent Destructive N. Idu Earthquake," Buzletin of the Earthquake Research Institute, Vol. 9, Tokyo, 1931.

38 Tanaka, T., "Period and Damping of Vibration in Actual Buildings During Earthquakes," Buzletin of the Earthquake Research Institute, Vol. 47, Tokyo, 1969.

39 N. M. Nielsen, and K. Nakagawa, The Tokachi-Oki Earthquake, Japan, May 16, 1968: A Preliminary Report on Damage to Structures, IISEE Report No. 2, International Institute of Seismology and Earthquake Engineering, Japan, 1968. 
PAC 40 Fukutomi, T., "On the Vibration of the Takeda Building," BuZZetin of the Earthquake Research Institute, Vol. 9, No. 4, Tokyo, 1931.

41 Acharya, H. K., "Mindanao Earthquake of August 16, 1976: Preliminary Seismological Assessment," Bulletin of the Seismological Society of America, Vol. 68, No. 5, 1978. 



\section{APPENDIX B}

Sample Listings of the HIRISE Data Base 



\section{SAMPLE LISTINGS OF THE HIRISE DATA-BASE}

\section{B.1 General Listings}

The product of this project's data-collection effort is stored at the Lawrence Berkeley Laboratory computer using the MRI SYSTEM 2000 data-base management system. Rather than a large computer output, this appendix includes a number of tables and figures that summarize certain features of the HIRISE data base and indicate the versatility of the data-base system.

Table B. 1 lists the total number of sites in each of the 27 urban areas included in the data base. The earthquakes considered in the study are listed chronologically by area in Table B.2. Tables B.3, B.4, and B.5 were generated by scanning the data and extracting a subset of elements meeting stated criteria. Site geology (element $\mathrm{C4}$ ) was used to select the elements shown in Table B.3, where all buildings listed are located on rock sites. Table 8.4 lists selected data for all sites affected by the Kern County earthquake of July 21, 1952. All buildings with a damage factor greater than 0.70 or a damage state equal to 8 , indicating collapse or condemnation, are 1 isted in Table B. 5 along with the earthquake ID, the number of stories, and the MMI.

The unique occurrences and frequency of occurrence can be tabulated for any KEY element in the data base. This is shown in Table B.6 for data-base elements $\mathrm{C4} 3$ and $\mathrm{C47}$, the number of stories and height code, respectively, along with the correlation between the two elements. For example, a height code of 3 is assigned to 105 buildings with 12 to 17 stories.

All available information for a specific building can be readily listed using the SYSTEM 2000 PRINT command. Examples of this are shown in Figures B.1, B.2, and B.3 for one building in each of three cities: Los Angeles, Mexico City, and Sendai, Japan. The data values following each asterisk may be interpreted with the help of the codes shown on the data collection forms reproduced in Chapter 3 (Figures 3.12 through 3.15 ). 
Data base HIRISE contains a wide variety of information describing the greater Los Angeles area and the effects of the San Fernando earthquake. Figure 3.4 is a graphic representation of the grid system showing the location code and soil type for each grid cell as well as the average MMl, the number of affected high-rise buildings, and the availability of ground motion records for the San Fernando earthquake. Many cells did not have any highrise buildings in 1971; the figure shows that approximately $45 \%$ of the buildings were concentrated in downtown Los Angeles in grid cell E06.

The high-rise building inventory for the Los Angeles area is listed in Table B.7, which shows selected data for each building. The most complete documentation was obtained for the buildings numbered 201 to 275 , which had strong-motion recording instruments in 1971 as required by the Los Angeles city building code. The majority of buildings were not instrumented, and these are numbered 501 and above. Some data items for these noninstrumented buildings were given assumed values because more complete information was unavailable. For example, design base shear values were calculated assuming a code design based on the date of construction and the number of floors. Buildings constructed prior to 1933 are shown as having no building code and a design base shear coefficient of 0.0. Data for the Los Angeles grid system is shown in Table B.8 including the latitude and longitude at the center of each grid cell and average values for the soil type, epicentral distance, MMI, and the duration of strong motion in seconds.

Two additional listings are included to illustrate the selectivity and sorting capabilities of the data-base system. The first, Table B.9, was generated by a scan of the building list to tally the number of buildings in each grid cell. These subtotals for each cell are also given in Figure B.4. The second example, Table B.10, includes only undamaged, reinforced concrete buildings in grid cell D06 (roughly the area bounded by 3 rd Street, Vermont Avenue, Rodeo Boulevard, and Hauser Boulevard). Fourteen of the eighteen 13-story buildings in the Park LaBrea complex were selected using these criteria. The remaining four buildings in this complex are also undamaged, reinforced concrete but are in grid cell c06 and thus were not listed. This sort-and-selection capability is important for use with correlation procedures. 
TABLE B. 1

$\frac{\text { NUMEER OF SITES IN EACH AREA }}{\text { 79/04/01 }}$

COUNTRY
* *
* UNITED STATES
* UNITED STATES
* UNITED STATES
* UNITED STATES
* UNITED STATES
* UNITED STATES
* UNITED STATES
* UNITED STATES
* UNITED STATES
* UNITED STATES
* UNITED STATES
* GUATEMALA
* MEXICO
* NICARAGUA
* VENEZUELA
* VENEZUELA
* GREECE
* ITALY
* MOROCCO
* ROMANIA
* YUGOSLAVIA
* JAPAN
* JAPAN
* JAPAN
* JAPAN
* JAPAN
* PHILIPPINES
JHIPA

UREAN AREA

NUMEER

OF SITES

ANCHORAGE

12

WI ITTIER

EAKERSFIELC

LOS ANGELES

OAKLAND

SAA FRANCISCO

1

SAA JOSE

SANTA BARBARA

OLYMPIA

SEATTLE

TACOMA

GUATEMALA

MEXICO

137

MANAGUA

CARABELLEDA

CARACAS

SALONICA

FRUILI

AGAOIR

BUCHAREST

SKOPJE

HACHINOHE

IZU PENINSULA

1

66

NI IGATA

SE NDAI

TOKYO

COTABATO

19

1

3

2

3

45

12

5

24

5

8

11

6

10

B-3 


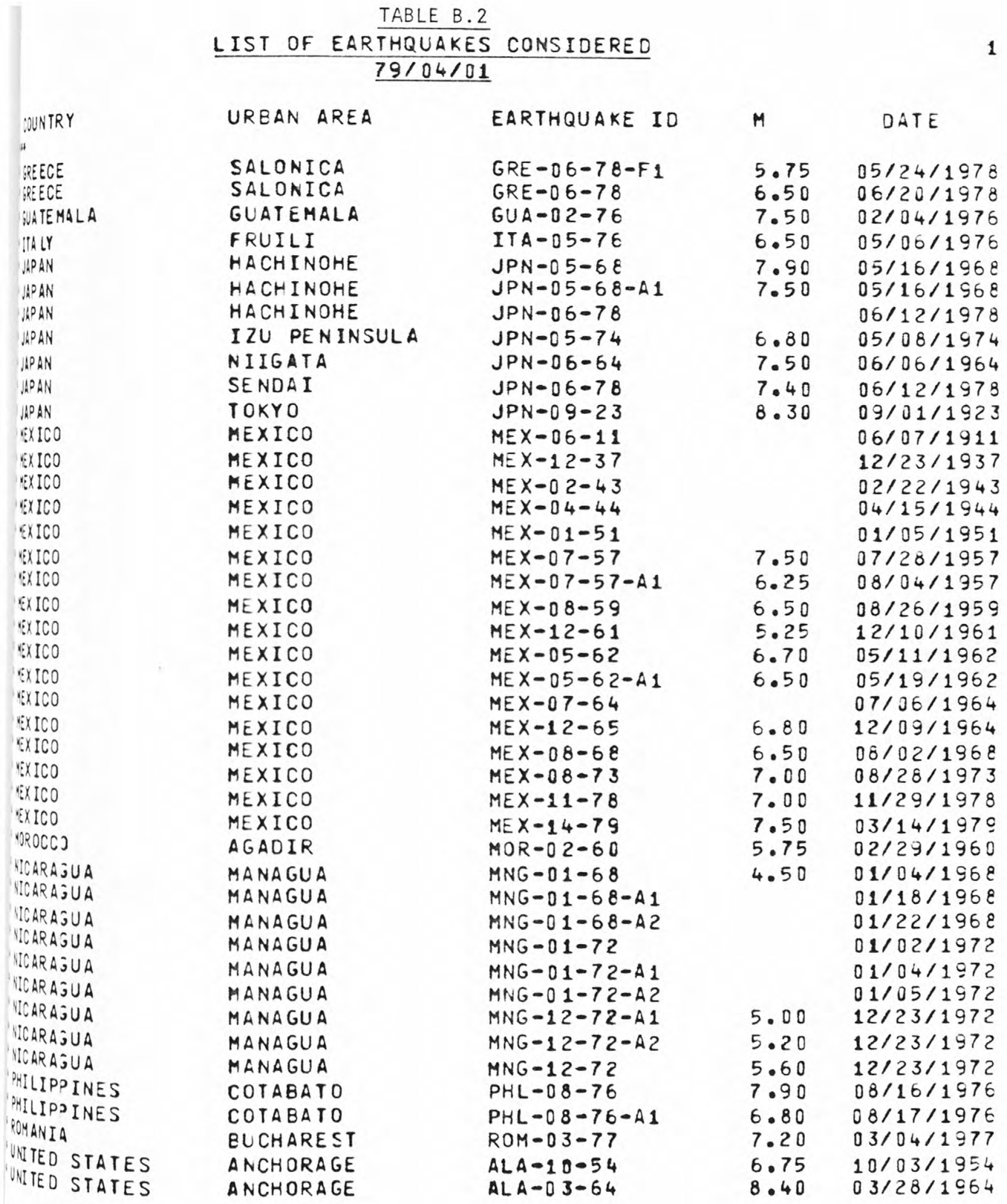


WUNTRY

NIED STATES

NITEO STATES

WITED STATES

WITEO STATES

WITEO STATES

WITED STATES

WNITEO STATES

WNTED STATES

WIIEO STATES

MIIEO STATES

UNITEO STATES

WITEO STATES

NITED STATES

WITED STATES

UITED STATES

WITED STATES

UNTED STATES

WITED STATES

UNTED STATES

UNIED STATES

UNIED STATES

NIIED STATES

WITEO STATES

NITEO STATES

WITED STATES

WITED STATES

NITEO STATES

WITED STATES

WITEO STATES

NITEO STATES

MITEO STATES

WNTED STATES

WITED STATES

WNITED STATES

WITED STATES

WITED STATES

WITEO STATES

NITED STATES

WIIED STATES

NITEO STATES

VNEZUELA

VNEZUELA

YUGOSLAVIA
UREAN AREA

BAKERSFIELD
BAKERSFIELD
BAKERSFIELD
LOS ANGELES
LOS ANGELES
LOS ANGELES
LOS ANGELES
LOS ANGELES
LOS ANGELES
LOS ANGELES
LOS ANGELES
OAKLAND

OAKLAND

OAKLAND

OAKLAND

OAKL AND

OLYMPIA

OLYMPIA

SAN FRANCISCO

SAN FRANCISCO

SAN FRANCISCO

SAN FRANCISCO

SAN FRANCISCO

SAN JOSE

SAN JOSE

SAN JOSE

SAN JOSE

SANTA BAREARA

SANTA BAREARA

SANTA BAREARA

SANYR BAREARA

SANTA BAREARA

SANTA BAREARA

SANTA BARBARA

SANTA BAREARA

SEATTLE

SEAT TLE

TACOMA

TACOMA

WHIT TIER

CARABELLEDA

CARACAS

SKOPJE
EARTHQUAKE ID

$K R N=07-52$

KRN-OB-52

SFD-02-71

$L B H-03-33$

$T O R-11-41$

$K R N-07-52$

$K R N-08-52$

BOR-0 4-68

LYT $-09-70$

SFD-02-71

$P M G-02-73$

SFR $-04-06$

JOS $-09-55$

$O A K-10-55$

$S F R-03-57$

ROS $-10-69$

OL $Y-04-49$

SEA-0 4-65

SFR-04-D6

JOS-09-55

$O A K-10-55$

$S F R-03-57$

ROS-10-69

SFR-0 4-06

JOS-09-55

$O A K-10-55$

$S F R-03-57$

$S B A-D 6-25$

$S B A-06-41$

$K R N-07-52$

$K R N-08-52$

$B O R-04-68$

SFD-02-71

$P M G-02-73$

SBA-0 8-78

OL $Y-04-4$ S

SEA-04-65

OL $Y-04-49$

SEA $=04-65$

ALA $-03-64$

YNZ $-07-67$

$V N Z-07-67$

$Y \cup G-07-63$
M

DATE

$07 / 21 / 1952$

$5.80 \quad 08 / 22 / 1952$

$02 / 09 / 1971$

$6.30 \quad 03 / 11 / 1933$

5. $40 \quad 11 / 14 / 1941$

$7.70 \quad 07 / 21 / 1952$

$08 / 22 / 1952$

$6.40 \quad 04 / 09 / 1968$

$5.40 \quad 09 / 12 / 1970$

E.40 02/09/1971

5.90 $02 / 21 / 1973$

$04 / 18 / 1906$

$09 / 05 / 1955$

$5.50 \quad 10 / 24 / 1955$

$03 / 22 / 1957$

$10 / 02 / 196 \%$

$7.10 \quad 04 / 13 / 1 \subseteq 49$

$04 / 29 / 1965$

$8.2504 / 18 / 1906$

$09 / 05 / 1955$

$10 / 24 / 1955$

$5.30 \quad 03 / 22 / 1957$

$5.70 \quad 10 / 02 / 1969$

$04 / 18 / 1906$

$5.80 \quad 09 / 05 / 1955$

$10 / 24 / 1955$

$03 / 22 / 1957$

$6.30 \quad 06 / 29 / 1925$

5.90 $07 / 01 / 1941$

$07 / 21 / 1952$

$08 / 22 / 1952$

$04 / 09 / 1968$

$02 / 09 / 1971$

$02 / 21 / 1973$

$5.10 \quad 08 / 13 / 1978$

$04 / 13 / 1 \subseteq 49$

$6.50 \quad 04 / 29 / 1965$

$04 / 13 / 1949$

$04 / 29 / 1965$

$03 / 28 / 1964$

$07 / 29 / 1967$

$6.50 \quad 07 / 29 / 1967$

$6.00 \quad 07 / 26 / 1963$ 
TABLE B. 3

SAMPLE LIST OF BUILOINGS ON ROCK SIIES

$04 / 29 / 79$

URBAN AREA

114

' LOS ANGELES

' IOS ANGELES

' $1 O S$ ANGELES

' $L O S$ ANGELES

' $L O S$ ANGELES

'LOS ANGELES

' $\mathrm{OSS}$ ANGELES

'SAN FRANCISCO
SITE INSTRU- SOIL NO. OF

ID MENTS TYPE STORIES

$220 \mathrm{BU}$

$222 \quad 8 U$

$2258 \mathrm{BU}$

$231 \quad B U$

$232 \quad B U$

$272 \quad H B$

$273 \mathrm{HB}$

$204 \quad \mathrm{HB}$

RK
$R K$
$R K$
$R K$
$R K$
$R K$
$R K$
$R K$

RK

RK

RK

RK

RK

RK
YEAR STRUCT. BUILT MATL.

$\begin{array}{ll}1965 & S T \\ 1968 & S T \\ 1966 & S T \\ 1962 & S T \\ 1968 & R C \\ 1930 & \\ 1927 & S T \\ 1960 & R C\end{array}$


TABLE B. 4

$\frac{\text { SELECTED DATA FOR THE KERN COUNTY EARTHQUAKE OF } 21 \text { JUL } 52}{\underline{79 / 04 / 01}}$

1

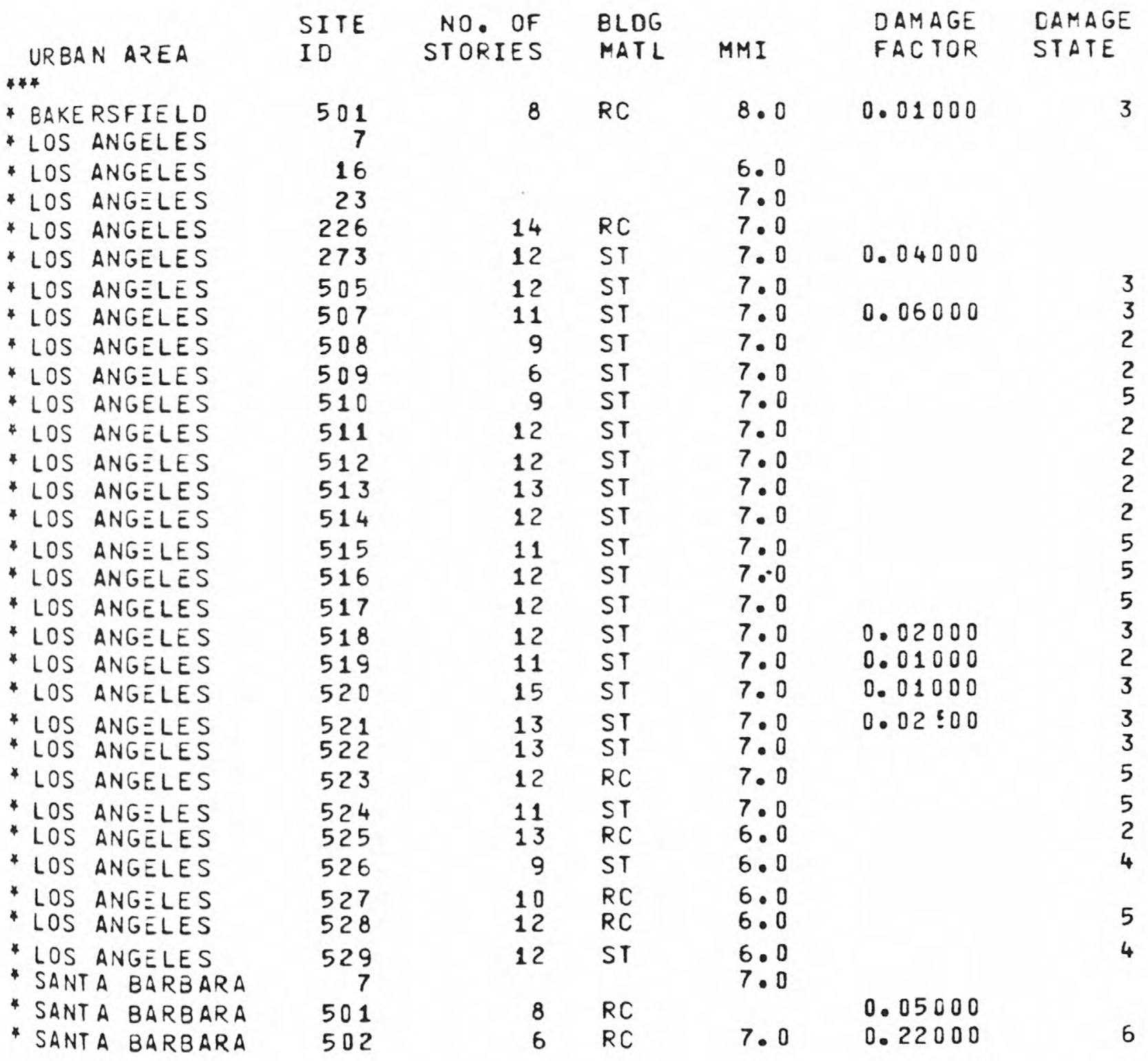


TABLE B. 5

LIST OF EXTENSIVELY DAMAGED BUILDINGS

1 $80 / 08 / 11$

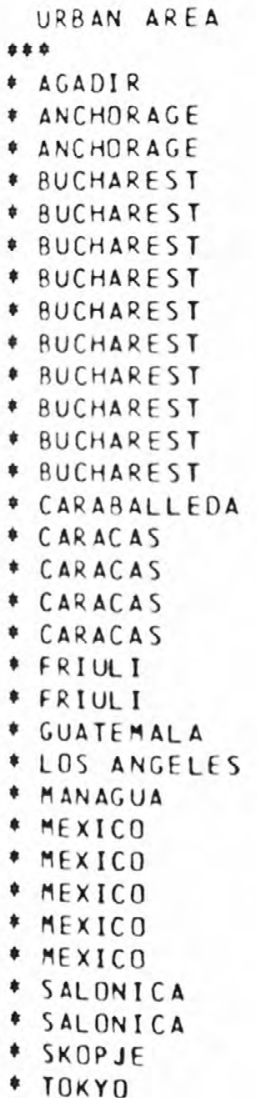

UR

- agadir

- anchorage

- bucharest

- bucharest

- bucharest

- caracas

- caracas

friUl I

- managua

- mexico

- Mexico

- salonica

- TOKYO

$\begin{array}{lc}\text { SITE } & \text { EARTHOUAKE } \\ \text { ID } & \text { ID } \\ 502 & \text { MOR-02-60 } \\ 501 & \text { ALA-03-64 } \\ 506 & \text { ALA-03-64 } \\ 501 & \text { ROM-03-77 } \\ 502 & \text { ROM-03-77 } \\ 503 & \text { ROM-03-77 } \\ 504 & \text { ROM-03-77 } \\ 505 & \text { ROM-03-77 } \\ 506 & \text { ROM-03-77 } \\ 507 & \text { ROM-03-77 } \\ 508 & \text { ROM-03-77 } \\ 510 & \text { ROM-03-77 } \\ 511 & \text { ROM-03-77 } \\ 503 & \text { VNZ-07-67 } \\ 501 & \text { VNZ-07-67 } \\ 502 & \text { VNZ-07-67 } \\ 503 & \text { VNZ-07-67 } \\ 504 & \text { VNZ-07-67 } \\ 501 & \text { ITA-05-76 } \\ 503 & \text { ITA-05-76 } \\ 501 & \text { GUA-02-76 } \\ 504 & \text { SFD-02-71 } \\ 509 & \text { MNC-12-72 } \\ 505 & \text { MEX-07-57 } \\ 510 & \text { MEX-07-57 } \\ 516 & \text { MEX-07-57 } \\ 517 & \text { MEX-07-57 } \\ 518 & \text { MEX-07-57 } \\ 201 & \text { GRE-06-78 } \\ 501 & \text { GRE-06-78 } \\ 501 & \text { YUG-07-63 } \\ 507 & \text { JPN-09-23 }\end{array}$

NO. OF STORIES

MMI

DAMAGE

FACTOR

DAMAGE STATE

$\begin{array}{rrr}8 & 10.0 & \\ 6 & 9.0 & 1.00000 \\ 6 & 9.0 & 1.00000\end{array}$

12

9

10

10

8

11

10

12

11

6

6

6
6

8.0

7.0

7.0

7.0

7.0

9.0

9.0

8.0

11.0

9.0

168.0

88.0

8.0
8.0

8.0

8.0

6.0

6.0

9.0

9.0

1.00000

1.00000 
TABLE B. 6

HEIGHT DISTRIBUTION FOR 338 BUILDINGS

THLY/EACH/C43:

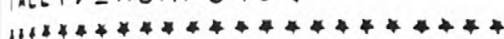

SLEMENT- STORIES ABOVE GRLDE

LLEMENT-

HEIGHT CODE /NI

BAEQUENCY VALUE

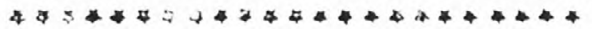

MEQCENCY

FREQUERTY

VALUE

\section{$3 \varepsilon$}

40

30

32

41

24

32

27

$1 \dot{c}$

11

s

o

5

3

$\epsilon$

2

1

1

1

1

1

1

1

1

1

1

1

1

\section{$\cdots \cdots \cdot-$}

20 UNIOLE LALUEJ

338 OCCURRENIES

Height Code 1: 6 to 8 stories Height Code 2: 9 to 11 stories Height Code 3: 12 to 17 stories Height Code 4: 18 to 43 stories 


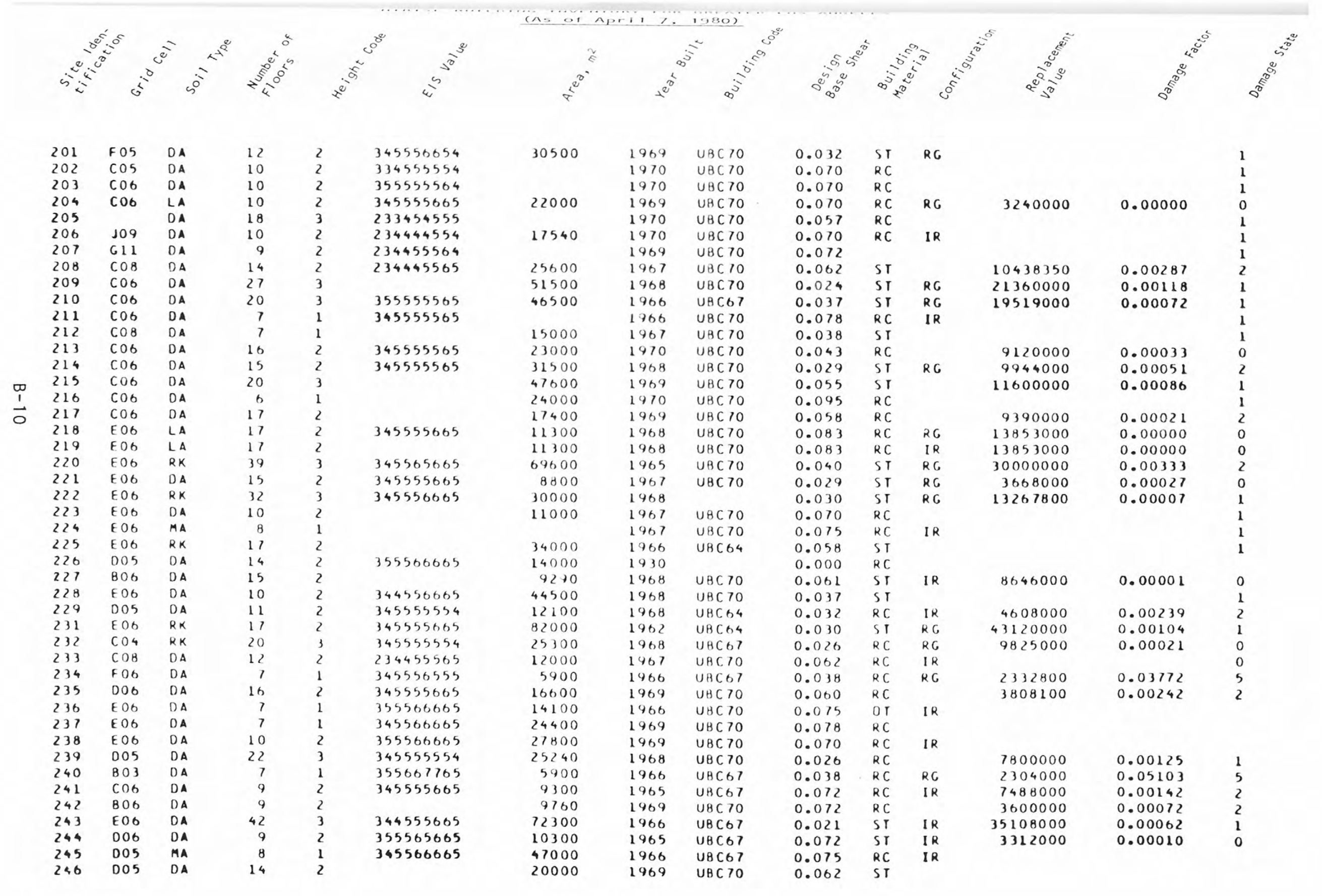




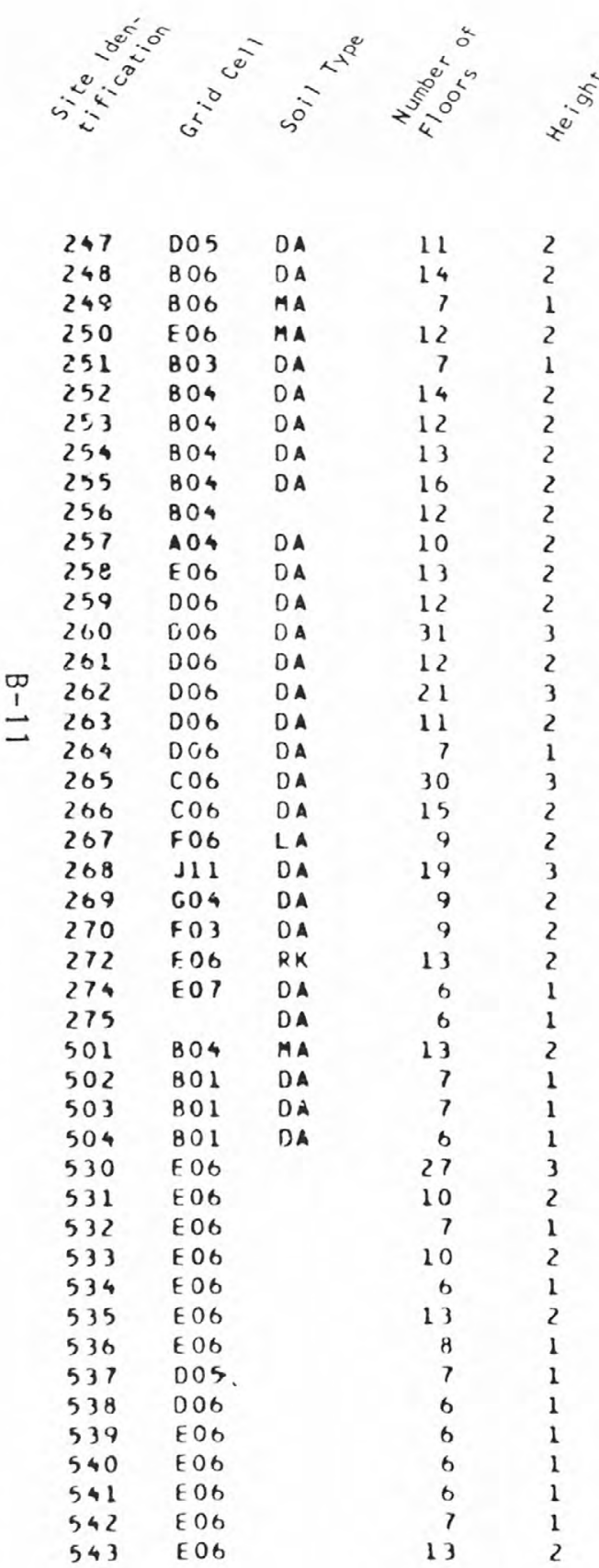
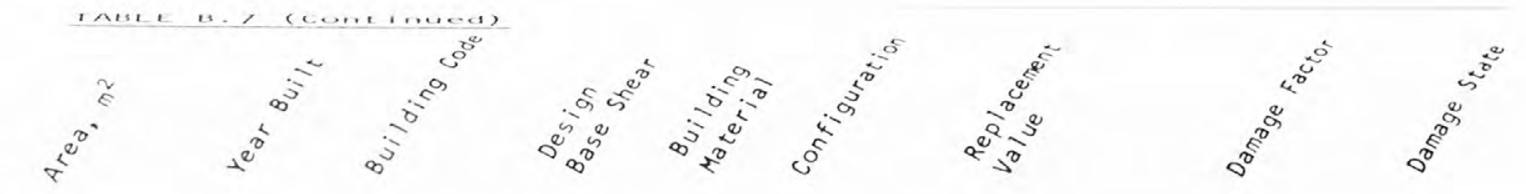

\begin{tabular}{|c|c|c|c|}
\hline \multirow{4}{*}{$\begin{array}{l}345455554 \\
234556665\end{array}$} & \multirow{3}{*}{$\begin{array}{l}8830 \\
9100\end{array}$} & \multirow{2}{*}{$\begin{array}{l}1968 \\
1966\end{array}$} & \multirow{2}{*}{$\begin{array}{l}\cup 8 C 70 \\
\cup B C O ?\end{array}$} \\
\hline & & & \\
\hline & & 1969 & $\cup B C 70$ \\
\hline & 6270 & 1966 & $48 C 67$ \\
\hline 345557775 & 21800 & 1970 & $\cup 8 C 73$ \\
\hline 356656775 & 15800 & 1966 & $48 \mathrm{CO}_{4}$ \\
\hline \multirow[t]{2}{*}{355556765} & 10900 & 1970 & UBC 70 \\
\hline & 11000 & 1967 & UBC 70 \\
\hline \multirow[t]{3}{*}{345566664} & 17900 & 1970 & $\cup B C>0$ \\
\hline & 55000 & 1969 & UAC 73 \\
\hline & 10200 & 1965 & $\cup B C 70$ \\
\hline \multirow[t]{3}{*}{344556664} & 21400 & 1970 & $\cup 8 C 70$ \\
\hline & 11800 & 1966 & U $8 C 70$ \\
\hline & 50000 & 1969 & UBC 70 \\
\hline \multirow[t]{2}{*}{345566665} & 26700 & 1966 & U BC 70 \\
\hline & 41300 & 1969 & บ8C70 \\
\hline 345556665 & 28000 & 1965 & $U B C>0$ \\
\hline \multirow[t]{2}{*}{345555665} & 8082 & 1966 & UBC 70 \\
\hline & 40000 & 1968 & U $B C>0$ \\
\hline 345555675 & 19000 & 1969 & $\cup B C>0$ \\
\hline 334555555 & 10100 & 1966 & $48 C 70$ \\
\hline 234444554 & 1700 & 1967 & $\cup 8 C>0$ \\
\hline \multirow{23}{*}{345555554} & 4330 & 1966 & U日C 70 \\
\hline & 8180 & 1966 & $\cup B C>0$ \\
\hline & 32500 & 1930 & \\
\hline & & 1930 & \\
\hline & & 1966 & U $8 C 70$ \\
\hline & 18600 & 1965 & U $8 C 70$ \\
\hline & 7400 & 1966 & UBC 70 \\
\hline & 13000 & 1961 & U 8 C 60 \\
\hline & & 1965 & U $8 C_{4}$ \\
\hline & 55700 & 1928 & NO \\
\hline & 13900 & 1953 & UBC \\
\hline & 31200 & 1932 & NO \\
\hline & 5390 & 1964 & $\triangle B C$ \\
\hline & & 1930 & NO \\
\hline & & 1925 & NO \\
\hline & & 1912 & NO \\
\hline & & 1928 & NO \\
\hline & & 1927 & NO \\
\hline & & 1920 & NO \\
\hline & & 1909 & NO \\
\hline & & 1907 & NO \\
\hline & & 1920 & NO \\
\hline & & 1918 & NO \\
\hline
\end{tabular}

0.067
0.062
0.078
0.066
0.040
0.077
0.057
0.064
0.029
0.066
0.070
0.064
0.053
0.048
0.047
0.054
0.048
0.078
0.048
0.061
0.079
0.056
0.068
0.072
0.000
0.000
0.083
0.064
0.045
0.052
0.045
0.000
0.041
0.000
0.070
0.000
0.000
0.000
0.000
0.000
0.000
0.000
0.000
0.000
0.000
0

(1)

0.00057

1

$R G$

$I R$
$R G$

5875000

4161600

4879750

5700000

0.00769

0.01293

0.01754

4312560

0.06000

6780000

$0.00004 \quad 0$

29640000

0.00002

0.00186 ?

13000800

4454500

$\begin{array}{ll}0.00232 & 2 \\ 0.00786 & 3\end{array}$

IR

18080000

0.00277

0.00000

c

I R

5167500

0.01935
0.00286

6

0.01597

0.16000

0.48000

1.00000

9500000

0.08667

15000000

5420000

8400000

0.00000

0.02524

0.00000

0.00000

0.00000

0.00000

0.00000

0.00000

0.00000

0.00000

0.00000

0.00000

0.00000 

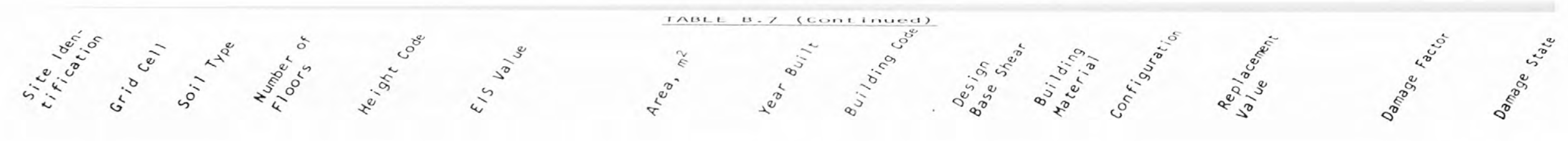

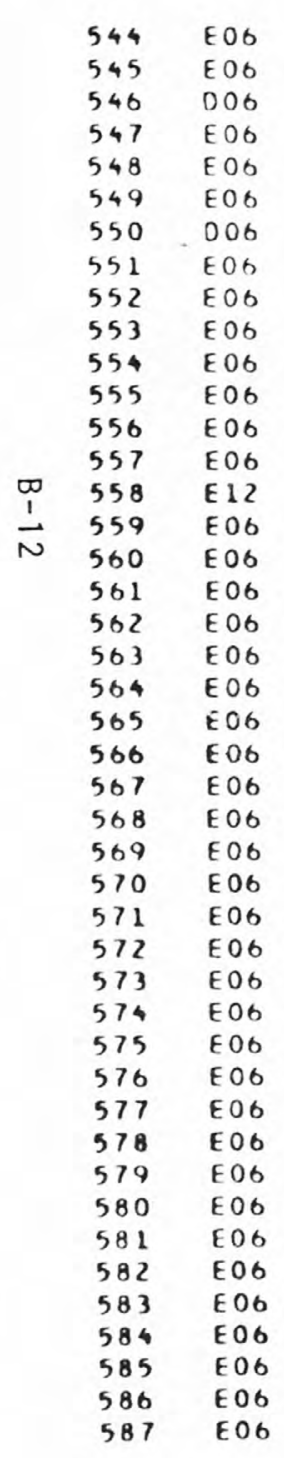

\begin{tabular}{|c|c|c|}
\hline & 1920 & NO \\
\hline & 1926 & NO \\
\hline & 1928 & NO \\
\hline & 1920 & NO \\
\hline & 1904 & NO \\
\hline & 1910 & NO \\
\hline & 1930 & NO \\
\hline & 1905 & NO \\
\hline \multirow[t]{2}{*}{650} & 1915 & NO \\
\hline & 1915 & NO \\
\hline \multirow{2}{*}{14600} & 1914 & NO \\
\hline & 1905 & NO \\
\hline 10400 & 1927 & NO \\
\hline 7840 & 1913 & NO \\
\hline \multirow[t]{3}{*}{13010} & 1964 & UBC \\
\hline & 1923 & NO \\
\hline & 1913 & NO \\
\hline \multirow[t]{4}{*}{7150} & 1930 & NO \\
\hline & 1906 & NO \\
\hline & 1920 & NO \\
\hline & 1921 & NO \\
\hline \multirow[t]{6}{*}{660} & 1911 & NO \\
\hline & 1933 & UBC \\
\hline & 1927 & NO \\
\hline & 1908 & NO \\
\hline & 1920 & NO \\
\hline & 1910 & NO \\
\hline \multirow[t]{2}{*}{18600} & 1923 & NO \\
\hline & 1924 & NO \\
\hline \multirow[t]{2}{*}{10100} & 1907 & NO \\
\hline & 1923 & NO \\
\hline \multirow[t]{2}{*}{20400} & 1912 & NO \\
\hline & 1906 & NO \\
\hline 6380 & 1914 & NO \\
\hline 3900 & 1921 & NO \\
\hline 46300 & 1912 & NO \\
\hline \multirow[t]{4}{*}{13000} & 1927 & NO \\
\hline & 1924 & NO \\
\hline & 1924 & NO \\
\hline & 1912 & NO \\
\hline 1630 & 1924 & NO \\
\hline \multirow[t]{2}{*}{11600} & 1926 & NO \\
\hline & 1927 & NO \\
\hline 7900 & 1924 & No \\
\hline
\end{tabular}

0.000
0.000
0.000
0.000
0.000
0.000
0.000
0.000
0.000
0.000
0.000
0.000
0.000
0.000
0.066
0.000
0.000
0.000
0.000
0.000
0.000
0.000
0.010
0.000
0.000
0.000
0.000
0.000
0.000
0.000
0.000
0.000
0.000
0.000
0.000
0.000
0.000
0.000
0.000
0.000
0.000
0.000
0.000
0.000

$\begin{array}{ll}R C & I R \\ R C & I R \\ S I & I R \\ S T & I R \\ R C & I R \\ S T & I R \\ R C & I R \\ R C & I R \\ S T & I R \\ S T & I R \\ S T & I R \\ R C & I R \\ S T & I R \\ R C & I R \\ S T & R G \\ S T & I R \\ S I & I R \\ S I & I R \\ R C & I R \\ R C & I R \\ R C & I R \\ R C & I R \\ R C & I R \\ R C & I R \\ S T & I R \\ R C & I R \\ R C & I R \\ R C & I R \\ R C & I R \\ R C & I R \\ S T & I R \\ S T & I R \\ S T & I R \\ S T & I R \\ S T & I R \\ S T & I R \\ S T & I R \\ R C & I R \\ R C & I R \\ R C & I R \\ R C & I R \\ R C & I R \\ R C & I R \\ R C & I R \\ R C & I R \\ R C & \end{array}$

175000

3915000

2800000

2109500

4770000

1925000

0.00000

0.00000

0.00000

0.00000

0.00000

0.00000

0.00000

0.02857

0.00000

0.03814

0.00000

0.01673

0.00000

0.00000

0.00000

0.00052

0.00000

0.00000

0.00000

88750

0.06761

0.00000

0.00000

0.00000

0.0000

5000000

0.02000

0.00000

0.08309

0.00000

5500000

0.00000

1717500

0.00000

524250

12469000

0.28612
0.00642

0.00642
0.00583

0.00000

0.00000

0.00000

219250

0.09122

3125000

0.02816

0.00000

2125000

0.00235

0
0
0
0
0
0
0
0
4
0
5
0
2
4
0
0
0
1
0
0
0
5
0
0
0
0
0
4
0
5
0
4
0
0
7
3
3
0
0
0
6
4
0
2



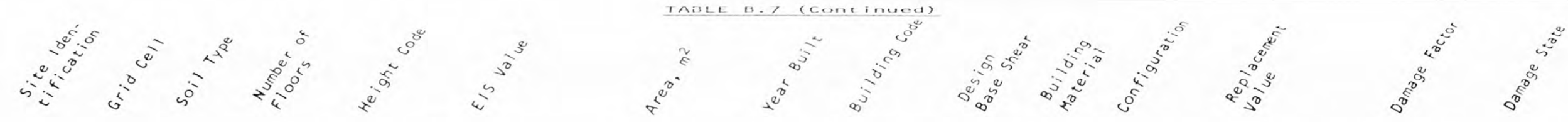

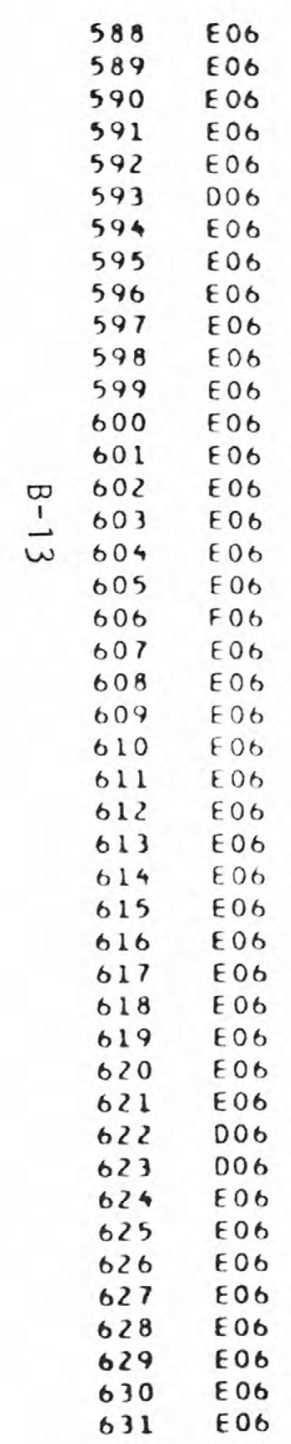

\begin{tabular}{|c|c|c|}
\hline \multirow[t]{5}{*}{3250} & 1923 & NO \\
\hline & 1920 & NO \\
\hline & 1916 & NO \\
\hline & 1925 & NO \\
\hline & 1925 & NO \\
\hline \multirow{6}{*}{13900} & 1961 & UBC \\
\hline & 1924 & NO \\
\hline & 1919 & NO \\
\hline & 1918 & NO \\
\hline & 1918 & NO \\
\hline & 1921 & NO \\
\hline \multirow[t]{3}{*}{11900} & 1929 & NO \\
\hline & 1914 & NO \\
\hline & 1919 & NO \\
\hline \multirow[t]{4}{*}{7780} & 1926 & NO \\
\hline & 1923 & NO \\
\hline & 1924 & NO \\
\hline & 1925 & No \\
\hline $17<0$ & 1963 & UBC \\
\hline \multirow{4}{*}{8920} & 1726 & NO \\
\hline & 10 & NO \\
\hline & 1720 & NO \\
\hline & 171 & NO \\
\hline \multirow{5}{*}{16700} & 1912 & NO \\
\hline & 1913 & Nn \\
\hline & 1915 & NO \\
\hline & 1923 & NO \\
\hline & 1926 & NO \\
\hline 6970 & 1905 & UBC \\
\hline 21000 & 1971 & UBC \\
\hline \multirow[t]{4}{*}{37200} & 1926 & NO \\
\hline & 1922 & NO \\
\hline & 1926 & NO \\
\hline & 1920 & NO \\
\hline \multirow[t]{6}{*}{1770} & 1964 & U8C \\
\hline & 1923 & NO \\
\hline & 1926 & NO \\
\hline & 1914 & NO \\
\hline & 1924 & NO \\
\hline & 1926 & NO \\
\hline \multirow{2}{*}{4980} & 1922 & 086 \\
\hline & 1915 & NO \\
\hline
\end{tabular}

$\begin{array}{lll}0.000 & R C & R G \\ 0.000 & R C & R G \\ 0.000 & R C & I R \\ 0.000 & R C & I R \\ 0.000 & R C & I R \\ 0.036 & S T & I R \\ 0.000 & R C & I R \\ 0.000 & \text { UM } & I R \\ 0.000 & \text { UM } & \text { IR } \\ 0.000 & \text { UM } & \text { IR } \\ 0.000 & R C & I R \\ 0.000 & R C & I R \\ 0.000 & S T & I R \\ 0.000 & S I & I R \\ 0.000 & S I & I R \\ 0.000 & R C & I R \\ 0.000 & R C & I R \\ 0.000 & R C & I R \\ 0.083 & R C & I R \\ 0.000 & R C & I R \\ 0.000 & S I & I R \\ 0.000 & S I & I R \\ 0.000 & R C & I R \\ 0.000 & S I & I R \\ 0.000 & S I & I R \\ 0.000 & S I & I R \\ 0.000 & U M & I R \\ 0.000 & S T & I R \\ 0.000 & S I & I R \\ 0.075 & S I & R G \\ 0.001 & S I & R G \\ 0.000 & S I & I R \\ 0.000 & R C & I R \\ 0.000 & S I & I R \\ 0.000 & S T & I R \\ 0.064 & S T & R C \\ 0.000 & R C & I R \\ 0.000 & R C & I R \\ 0.000 & R C & I R \\ 0.000 & R C & I R \\ 0.000 & R C & I R \\ 0.057 & R C & I R \\ 0.000 & R C & I R \\ 0.000 & S T & I R \\ 0.000 & & \text { IR }\end{array}$

875000

0.00000

0.00000

0.00000

0.00000

0.00000

0.00000

0.00000

0.00000

0.00000

0.00434

0.00000

0.00000

2094000

0.04059

0.000000

0.00000

0.05779

2077000

0.04046

0.00000

0.00000

0.00000

0.00000

0.00000

0.00000

0.00000

0.00000

0.00000

5254800

5110000

0.11000

0.1000

0.00000

0.00000

785000

0.00000

0.00000

. 00000

0.00000

0.00000

0.00403

670000

0.00000 

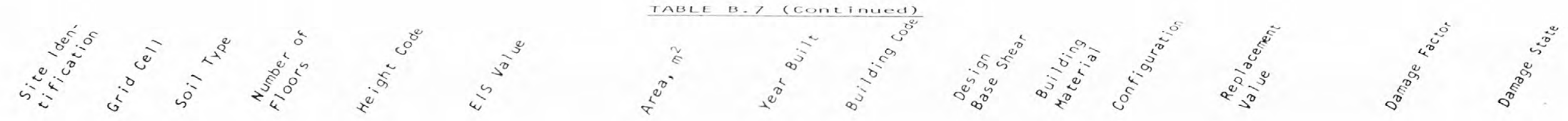

\begin{tabular}{ll}
632 & $E 06$ \\
633 & $E 06$ \\
634 & $E 06$ \\
635 & $E 06$ \\
636 & $E 06$ \\
637 & $E 06$ \\
638 & $E 06$ \\
639 & $E 06$ \\
640 & $E 06$ \\
641 & $E 06$ \\
642 & $E 06$ \\
643 & $E 06$ \\
644 & $E 06$ \\
645 & $E 06$ \\
646 & $E 06$ \\
607 & $E 06$ \\
\hline 648 & $E 06$ \\
6069 \\
649 & $E 06$ \\
650 & $E 06$ \\
651 & $E 06$ \\
652 & $D 06$ \\
653 & $E 07$ \\
654 & $B 07$ \\
655 & $C 08$ \\
656 & $D 06$ \\
657 & $E 06$ \\
658 & 006 \\
659 & $D 05$ \\
660 & $C 06$ \\
661 & $C 06$ \\
662 & $C 06$ \\
663 & $C 06$ \\
664 & $C 06$ \\
665 & $E 06$ \\
666 & $E 06$ \\
667 & $E 05$ \\
668 & $D 06$ \\
669 & $B 06$ \\
670 & $C 06$ \\
671 & 806 \\
672 & $C 05$ \\
673 & $C 05$ \\
674 & $E 06$ \\
675 & $E 06$ \\
&
\end{tabular}

\begin{tabular}{|c|c|c|}
\hline 20440 & 1921 & NO \\
\hline \multirow{4}{*}{9480} & 1959 & UBC \\
\hline & 1931 & NO \\
\hline & 1925 & NO \\
\hline & 1920 & NO \\
\hline \multirow[t]{2}{*}{10220} & 1929 & NO \\
\hline & 1924 & NO \\
\hline 3120 & 1906 & NO \\
\hline 9290 & 1927 & NO \\
\hline 44600 & 1963 & UBC \\
\hline \multirow[t]{2}{*}{44600} & 1965 & UBC \\
\hline & 1920 & NO \\
\hline \multirow[t]{3}{*}{16200} & 1913 & NO \\
\hline & 1925 & NO \\
\hline & 1927 & NO \\
\hline \multirow[t]{7}{*}{18580} & 1925 & NO \\
\hline & 1924 & NO \\
\hline & 1923 & NO \\
\hline & 1963 & $U B C$ \\
\hline & 1962 & UBC \\
\hline & 1962 & UBC \\
\hline & 1925 & NO \\
\hline 16200 & 1970 & U BC \\
\hline \multirow[t]{5}{*}{13800} & 1963 & UBC \\
\hline & 1920 & NO \\
\hline & 1913 & NO \\
\hline & 1929 & NO \\
\hline & 1928 & NO \\
\hline 27900 & 1964 & $U B C$ \\
\hline 27900 & 1964 & U8C \\
\hline 74320 & 1966 & UBC \\
\hline 39300 & 1965 & UBC \\
\hline \multirow[t]{5}{*}{39300} & 1965 & UBC \\
\hline & 1913 & NO \\
\hline & 1920 & N0 \\
\hline & 1932 & NO \\
\hline & 1920 & No \\
\hline \multirow[t]{2}{*}{17200} & 1961 & $U A C$ \\
\hline & 1968 & UBC \\
\hline 11600 & 1963 & U8 C \\
\hline 10220 & 1955 & UBC \\
\hline \multirow[t]{3}{*}{12800} & 1962 & UBC \\
\hline & 1922 & No \\
\hline & 1940 & U8 C \\
\hline
\end{tabular}

$\begin{array}{lll}0.000 & R C & I R \\ 0.034 & S T & R G \\ 0.000 & R C & I R \\ 0.000 & R C & I R \\ 0.000 & S T & I R \\ 0.000 & R C & I R \\ 0.000 & S T & I R \\ 0.000 & R C & I R \\ 0.000 & S I & I R \\ 0.062 & S T & R G \\ 0.064 & S T & R G \\ 0.000 & R C & I R \\ 0.000 & S T & I R \\ 0.000 & S T & I R \\ 0.000 & S T & I R \\ 0.000 & S T & I R \\ 0.000 & R C & I R \\ 0.000 & R C & I R \\ 0.075 & R C & R G \\ 0.075 & R C & R G \\ 0.083 & R C & R G \\ 0.000 & R C & I R \\ 0.066 & R C & R G \\ 0.075 & R C & R C \\ 0.000 & R C & I R \\ 0.000 & R C & I R \\ 0.000 & R C & I R \\ 0.000 & U M & I R \\ 0.064 & S T & R G \\ 0.064 & S T & R G \\ 0.060 & S T & I R \\ 0.050 & S T & R G \\ 0.050 & S T & R G \\ 0.000 & R C & I R \\ 0.000 & R C & I R \\ 0.000 & S T & I R \\ 0.000 & 0 I & I R \\ 0.041 & S T & R G \\ 0.066 & R C & I R \\ 0.070 & R C & R G \\ 0.044 & S I & I R \\ 0.072 & S T & R G \\ 0.000 & R C & I R \\ 0.010 & S T & I R \\ & & \end{array}$

5500000

4300000

2750000

040000

2500000

17172000

17172000

4350000

5000000

(2)

3500000

5565000

13700000

13700000

32112000

13100000

13100000

5080000

2679150

2750000

2450000

0.010 

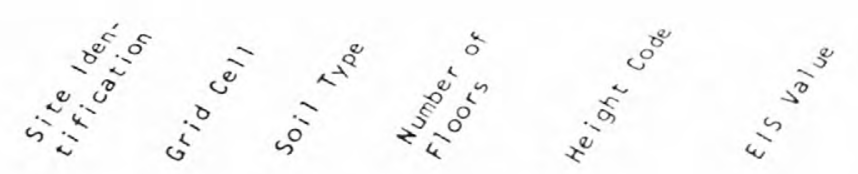

$\begin{array}{ll}676 & \text { EO6 } \\ 677 & B O 7 \\ 678 & \text { EO6 } \\ 679 & \text { EO6 } \\ 680 & \text { EO6 } \\ 681 & \text { EO6 } \\ 682 & \text { EO6 } \\ 683 & \text { EO6 } \\ 684 & \text { EO6 } \\ 685 & \text { EO6 } \\ 686 & \text { EO6 } \\ 687 & \text { EO6 } \\ 688 & \text { EO6 } \\ 689 & \text { EO6 } \\ 690 & \text { EO6 } \\ 691 & \text { EO6 } \\ 692 & \text { EO6 } \\ 693 & \text { EO6 } \\ 694 & \text { EO6 } \\ 606 \\ 695 & \text { EO6 } \\ 696 & \text { EO6 } \\ 697 & \text { EO6 } \\ 698 & \text { EO6 } \\ 699 & \text { EO6 } \\ 700 & \text { EO6 } \\ 701 & \text { EO6 } \\ 702 & \text { EO6 } \\ 703 & \text { EO6 } \\ 704 & \text { EO6 } \\ 705 & \text { EO6 } \\ 706 & \text { EO6 } \\ 707 & \text { EO6 } \\ 708 & \text { EO6 } \\ 709 & \text { EO6 } \\ 710 & \text { EO6 } \\ 711 & \text { EO6 } \\ 712 & \text { EO6 } \\ 713 & \text { EO6 } \\ 714 & \text { EO6 } \\ 715 & \text { EO6 } \\ 716 & \text { EO6 } \\ 717 & \text { EO6 } \\ 718 & \text { EO6 } \\ 719 & \text { EO6 }\end{array}$

$\begin{array}{rl}14 & 2 \\ 7 & 2 \\ 8 & 1 \\ 10 & 2 \\ 7 & 1 \\ 6 & 1 \\ 7 & 1 \\ 7 & 1 \\ 11 & 2 \\ 10 & 2 \\ 6 & 1 \\ 6 & 1 \\ 6 & 1 \\ 11 & 2 \\ 7 & 1 \\ 9 & 2 \\ 10 & 2 \\ 7 & 1 \\ 12 & 2 \\ 6 & 1 \\ 6 & 1 \\ 7 & 1 \\ 7 & 1 \\ 7 & 1 \\ 8 & 1 \\ 11 & 2 \\ 13 & 2 \\ 6 & 1 \\ 8 & 1 \\ 12 & 2 \\ 6 & 1 \\ 12 & 2 \\ 12 & 2 \\ 13 & 2 \\ 12 & 2 \\ 6 & 1 \\ 8 & 1 \\ 15 & 2 \\ 11 & 2 \\ 7 & 1 \\ 12 & 2 \\ 10 & 2 \\ 13 & 2 \\ 12 & 2\end{array}$
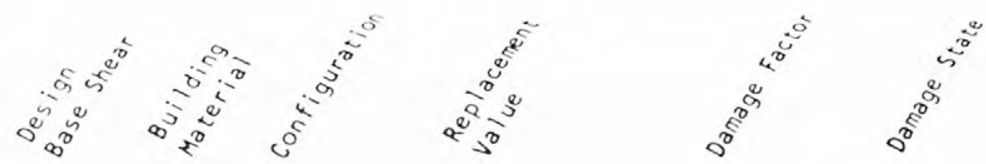

\begin{tabular}{|c|c|c|}
\hline 40100 & 1958 & UBC \\
\hline \multirow[t]{12}{*}{47700} & 1958 & $U \times C$ \\
\hline & 1931 & NO \\
\hline & 1911 & NO \\
\hline & 1905 & NO \\
\hline & 1902 & NO \\
\hline & 1920 & NO \\
\hline & 1920 & NO \\
\hline & 1914 & NO \\
\hline & 1907 & NO \\
\hline & 1920 & NO \\
\hline & 1920 & NO \\
\hline & 1923 & NO \\
\hline 10300 & 1910 & NO \\
\hline \multirow[t]{2}{*}{22100} & 1924 & NO \\
\hline & 1907 & NO \\
\hline \multirow[t]{18}{*}{11900} & 1913 & NO \\
\hline & 1906 & NO \\
\hline & 1921 & NO \\
\hline & 1920 & nO \\
\hline & 1920 & NO \\
\hline & 1920 & NO \\
\hline & 1920 & NO \\
\hline & 1920 & NO \\
\hline & 1914 & NO \\
\hline & 1912 & NO \\
\hline & 1912 & NO \\
\hline & 1924 & NO \\
\hline & 1943 & U BC \\
\hline & 1924 & NO \\
\hline & 1913 & NO \\
\hline & 1928 & NO \\
\hline & 1925 & NO \\
\hline & 1929 & NO \\
\hline \multirow[t]{7}{*}{23200} & 1930 & NO \\
\hline & 1917 & NO \\
\hline & 1914 & NO \\
\hline & 1927 & NO \\
\hline & 1924 & NO \\
\hline & 1913 & NO \\
\hline & 1925 & NO \\
\hline 7520 & 1921 & NO \\
\hline 1250 & 1925 & NO \\
\hline 79900 & 1957 & UBC \\
\hline
\end{tabular}

0.033
0.044
0.000
0.000
0.000
0.000
0.000
0.000
0.000
0.000
0.000
0.000
0.000
0.000
0.000
0.000
0.000
0.000
0.000
0.000
0.000
0.000
0.000
0.000
0.000
0.000
0.000
0.000
0.048
0.000
0.000
0.000
0.000
0.000
0.000
0.000
0.000
0.000
0.000
0.000
0.000
0.000
0.000
0.036

$\begin{array}{ll}S T & I R \\ R C & R C \\ S T & I R \\ R C & I R \\ S T & I R \\ R C & I R \\ U M & I R \\ S T & I R \\ R C & I R \\ R C & I R \\ U M & I R \\ S T & I R \\ O T & I R \\ S T & I R \\ R C & I R \\ R C & I R \\ S T & I R \\ S T & I R \\ S T & I R \\ S T & I R \\ S T & I R \\ S T & I R \\ S T & I R \\ S T & I R \\ R C & I R \\ S T & I R \\ S T & I R \\ S T & I R \\ R C & I R \\ U M & I R \\ R C & I R \\ S T & I R \\ S T & I R \\ S T & I R \\ S T & I R \\ S T & I R \\ R C & I R \\ S T & I R \\ R C & I R \\ R C & I R \\ R C & I R \\ R C & I R \\ R C & I R \\ S T & I R \\ & \\ S C & \end{array}$

16200000 0.00000 0.00000 0.00000 0.00000 0.00000 0.00000 0.00000 0.00000 0.04916 0.00000 0.00000 0.00000 0.00592 0.00114 0.00000 0.01044 0.00000 0.00000 0.00000 0.00000 0.00000 0.00000 0.00000 0.00000 0.00000 0.00000 0.00000 0.00000 0.00000 0.00000 0.00000 0.00000 0.00000 0.00800 0.00000 0.00000 0.00000 0.00000 0.00000 0.00000 0.00000 0.02794 $\begin{array}{ll}336000 & 0.47619 \\ 5800000 & 0.00167\end{array}$ 


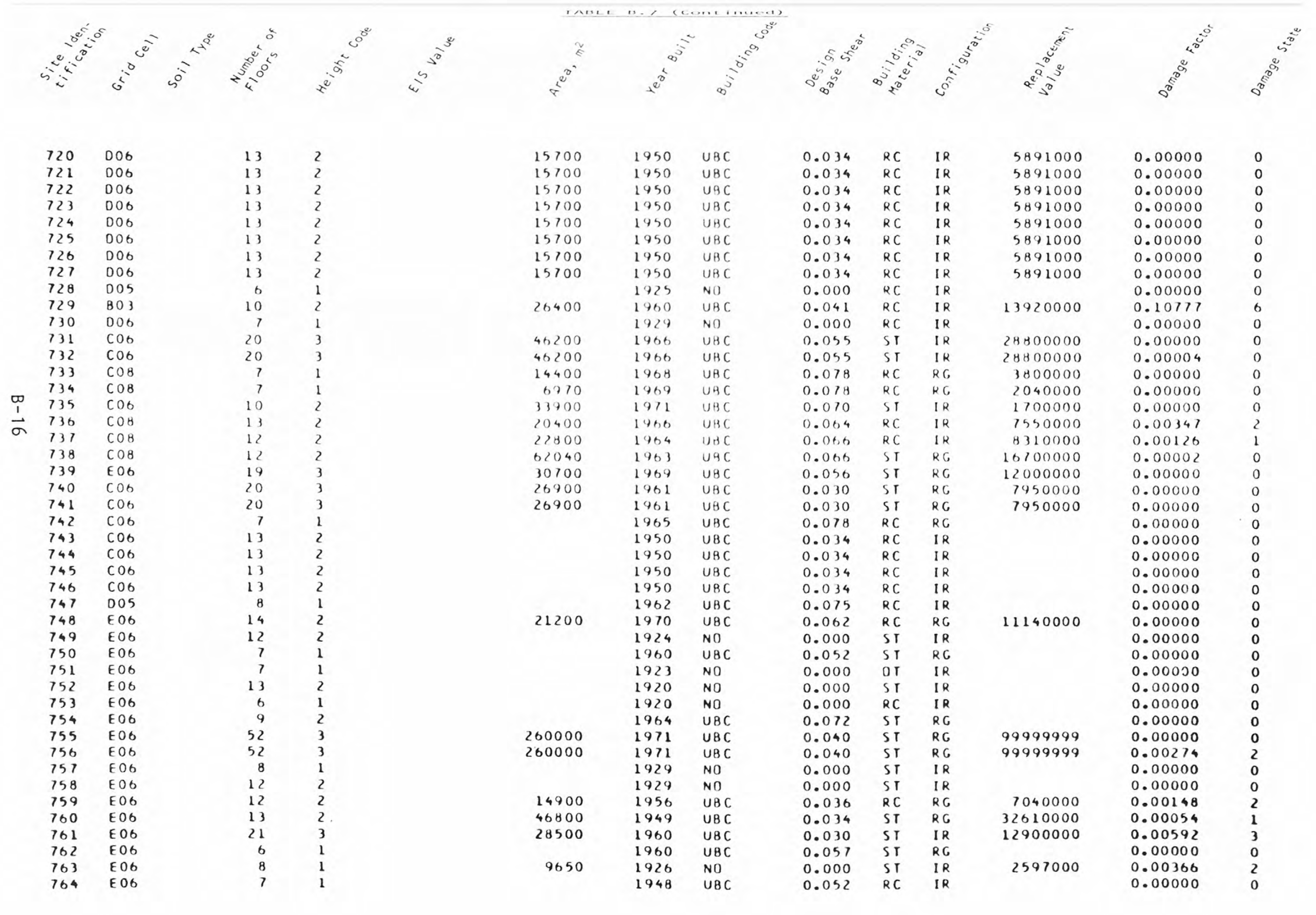



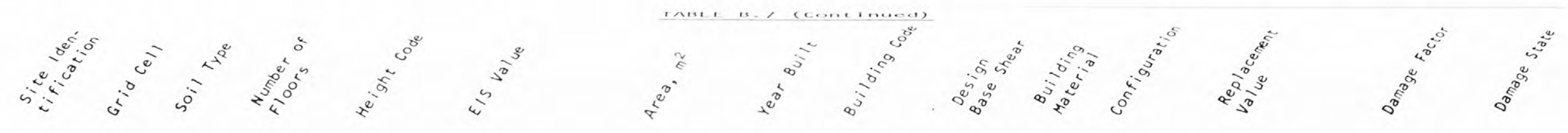

\begin{tabular}{|c|c|c|}
\hline & 765 & E06 \\
\hline & 766 & E06 \\
\hline & 767 & EO6 \\
\hline & 768 & EO6 \\
\hline & 769 & EO6 \\
\hline & 770 & EO6 \\
\hline & 771 & 005 \\
\hline & 772 & 005 \\
\hline & 773 & 005 \\
\hline & 774 & 005 \\
\hline & 775 & 006 \\
\hline & 776 & 006 \\
\hline & 777 & 006 \\
\hline & 778 & 806 \\
\hline & 779 & 006 \\
\hline & 780 & 006 \\
\hline & 781 & $D 06$ \\
\hline & 782 & DOG \\
\hline & 783 & EOB \\
\hline & 784 & EOb \\
\hline & 785 & EO6 \\
\hline & 786 & EO6 \\
\hline & 787 & EO6 \\
\hline & 788 & EO6 \\
\hline & 789 & EO6 \\
\hline & 790 & EO6 \\
\hline & 791 & EO6 \\
\hline & 792 & EOB \\
\hline & 793 & EOO \\
\hline & 794 & EO6 \\
\hline & 795 & E07 \\
\hline & 796 & E07 \\
\hline & 797 & 000 \\
\hline & 798 & 006 \\
\hline & 799 & 006 \\
\hline & 800 & DOS \\
\hline & 801 & 005 \\
\hline & 802 & 005 \\
\hline & 803 & 806 \\
\hline & 804 & EO6 \\
\hline & 805 & $\mathrm{COO}$ \\
\hline & 806 & EO6 \\
\hline & 807 & EO6 \\
\hline & 808 & E06 \\
\hline & 809 & EO6 \\
\hline
\end{tabular}

\begin{tabular}{|c|c|c|}
\hline & 1924 & NO \\
\hline & 1923 & NO \\
\hline & 1941 & $U B C$ \\
\hline & 1952 & $U B C$ \\
\hline & 1924 & NO \\
\hline & 1958 & $U B C$ \\
\hline 27400 & 1951 & $U B C$ \\
\hline & 1928 & No \\
\hline & 1931 & NO \\
\hline 38600 & 1964 & UBC \\
\hline 15700 & 1950 & UBC \\
\hline 15700 & 1950 & UBC \\
\hline 15700 & 1950 & U B C \\
\hline 27900 & 1962 & UBC \\
\hline & 1929 & NO \\
\hline & 1931 & NO \\
\hline & 1923 & NO \\
\hline & 1926 & NO \\
\hline & 1963 & UBC \\
\hline & 1961 & UBC \\
\hline & 1947 & UBC \\
\hline 13000 & 1927 & NO \\
\hline & 1924 & NO \\
\hline 65000 & 1964 & UBC \\
\hline 6500 & 1926 & NO \\
\hline & 1963 & UBC \\
\hline & 1924 & NO \\
\hline & 1913 & NO \\
\hline & 1913 & NO \\
\hline & 1945 & $U B C$ \\
\hline & 1922 & NO \\
\hline & 1921 & NO \\
\hline 15700 & 1950 & UBC \\
\hline 15700 & 1950 & U BC \\
\hline 15700 & 1950 & $\cup 8 C$ \\
\hline 9290 & 1958 & U BC \\
\hline 11150 & 1964 & $\cup B C$ \\
\hline 2800 & 1928 & NO \\
\hline 18900 & 1961 & บ8C \\
\hline & 1926 & NO \\
\hline & 1907 & NO \\
\hline & 1910 & NO \\
\hline & 1920 & NO \\
\hline & 1907 & NO \\
\hline & 1913 & NO \\
\hline
\end{tabular}

$\begin{array}{lll}0.000 & S T & I R \\ 0.000 & R C & I R \\ 0.010 & R C & R G \\ 0.057 & R C & R G \\ 0.000 & R C & I R \\ 0.057 & S T & I R \\ 0.044 & S T & I R \\ 0.000 & S T & I R \\ 0.000 & S T & I R \\ 0.064 & R C & I R \\ 0.034 & R C & I R \\ 0.034 & R C & I R \\ 0.034 & R C & I R \\ 0.055 & S T & R G \\ 0.000 & R C & I R \\ 0.000 & R C & I R \\ 0.000 & R C & I R \\ 0.000 & R C & I R \\ 0.083 & S T & I R \\ 0.052 & R C & R C \\ 0.041 & S T & R G \\ 0.000 & R C & I R \\ 0.000 & R C & I R \\ 0.048 & S T & R G \\ 0.000 & S T & I R \\ 0.083 & R C & I R \\ 0.000 & R C & I R \\ 0.000 & R C & I R \\ 0.000 & R C & I R \\ 0.057 & R C & I R \\ 0.000 & U M & I R \\ 0.000 & R C & I R \\ 0.034 & R C & I R \\ 0.034 & R C & I R \\ 0.034 & R C & I R \\ 0.036 & S T & I R \\ 0.072 & R C & I R \\ 0.000 & R C & I R \\ 0.033 & R C & I R \\ 0.000 & S T & I R \\ 0.000 & R C & I R \\ 0.000 & R C & I R \\ 0.000 & R C & I R \\ 0.000 & S T & I R \\ 0.000 & R C & I R\end{array}$

0.00000

0.00000

0.00000

0.00000

0.00000

7364000

0.13145

0.00000

0.00000

10500000

5891000

5891000

5891000

0.00000

0.00000

0.00000
0.00000

0.00000

0.00000

0.00000

0.00000

0.00000

0.00000

0.00000

0.00000

3510000

0.0057

0.00000

32650000

1750000

0.00200

0.00000

0.00000

0.00000

0.00000

0.00000

0.00000

5891000

5891000

0.0000

5891000

0.00000

0.00069

2500000
3660000

0.00057

750000

0.00000

6590000

0.00000

0.00000

0.00000

0.00000

0.00000

0.00000 

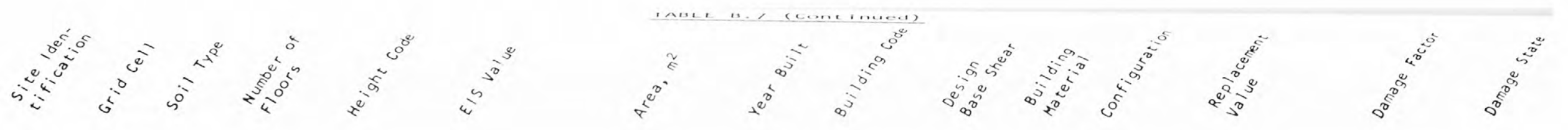

\begin{tabular}{ll}
810 & $E 06$ \\
811 & $E 06$ \\
812 & $E 06$ \\
813 & $E 06$ \\
814 & $E 06$ \\
815 & $E 06$ \\
816 & $E 06$ \\
817 & $E 06$ \\
818 & $E 06$ \\
819 & $E 06$ \\
820 & $E 06$ \\
821 & $E 06$ \\
822 & $E 06$ \\
823 & $E 06$ \\
824 & $E 06$ \\
825 & $E 06$ \\
\hline 826 & $E 06$ \\
827 & $E 06$ \\
828 & $E 06$ \\
829 & $E 06$ \\
830 & $D 05$ \\
831 & $E 06$ \\
832 & 005 \\
833 & 006 \\
834 & $D 06$ \\
835 & $D 05$ \\
836 & 005 \\
837 & 005 \\
838 & $D 05$ \\
839 & $D 05$ \\
840 & $D 05$ \\
841 & 005 \\
842 & 005 \\
843 & 005 \\
844 & 005 \\
845 & 005 \\
846 & 005 \\
847 & 005 \\
848 & $D 05$ \\
849 & 005 \\
850 & 005 \\
851 & $E 06$ \\
852 & $E 06$ \\
853 & $E 06$ \\
854 & $E 06$ \\
8 &
\end{tabular}

\begin{tabular}{|c|c|}
\hline 10 & 2 \\
\hline 12 & 2 \\
\hline 12 & 2 \\
\hline 9 & 2 \\
\hline 13 & 2 \\
\hline 12 & 2 \\
\hline 8 & 1 \\
\hline 8 & 1 \\
\hline 8 & 1 \\
\hline 13 & 2 \\
\hline 12 & 2 \\
\hline 7 & 1 \\
\hline 7 & 1 \\
\hline 13 & 2 \\
\hline 12 & 2 \\
\hline 6 & 1 \\
\hline 7 & 1 \\
\hline 10 & 2 \\
\hline 30 & 3 \\
\hline 8 & 1 \\
\hline 7 & 1 \\
\hline 11 & 2 \\
\hline 6 & 1 \\
\hline 7 & 1 \\
\hline 6 & 1 \\
\hline 7 & 1 \\
\hline 12 & 2 \\
\hline 9 & 2 \\
\hline 12 & 2 \\
\hline 7 & l \\
\hline 6 & 1 \\
\hline 9 & 2 \\
\hline 7 & 1 \\
\hline 12 & 2 \\
\hline 12 & 2 \\
\hline 7 & 1 \\
\hline 12 & 2 \\
\hline 14 & 2 \\
\hline 8 & 1 \\
\hline 12 & 2 \\
\hline 13 & 2 \\
\hline 8 & 1 \\
\hline 6 & 1 \\
\hline 13 & 2 \\
\hline 11 & 2 \\
\hline
\end{tabular}

\begin{tabular}{|c|c|c|}
\hline 2420 & 1930 & NO \\
\hline \multirow[t]{2}{*}{900} & 1925 & NO \\
\hline & 1919 & No \\
\hline 12500 & 1909 & NO \\
\hline \multirow{2}{*}{4650} & 1928 & NO \\
\hline & 1930 & NO \\
\hline \multirow[t]{3}{*}{4980} & 1925 & NO \\
\hline & 1934 & UBC \\
\hline & 1907 & NO \\
\hline \multirow[t]{8}{*}{13000} & 1929 & NO \\
\hline & 1922 & NO \\
\hline & 1922 & NO \\
\hline & 1914 & NO \\
\hline & 1924 & NO \\
\hline & 1924 & NO \\
\hline & 1920 & NO \\
\hline & 1912 & ND \\
\hline 0410 & 1423 & NO \\
\hline 65000 & 1965 & UBC \\
\hline \multirow[t]{2}{*}{61300} & 1970 & UBC \\
\hline & 1929 & N0 \\
\hline \multirow[t]{8}{*}{26000} & 1964 & U8C \\
\hline & 1962 & UBC \\
\hline & 1929 & NO \\
\hline & 1920 & NO \\
\hline & 1927 & NO \\
\hline & 1929 & NO \\
\hline & 1928 & N0 \\
\hline & 1924 & NO \\
\hline 6300 & 1925 & NO \\
\hline 5570 & 1929 & NO \\
\hline 6000 & 1921 & No \\
\hline 6040 & 1957 & $U B C$ \\
\hline 5090 & 1927 & NO \\
\hline \multirow[t]{2}{*}{9480} & 1959 & UBC \\
\hline & 1925 & NO \\
\hline \multirow{3}{*}{18600} & 1965 & UBC \\
\hline & 1926 & NO \\
\hline & 1926 & NO \\
\hline 13470 & 1969 & UBC \\
\hline \multirow[t]{5}{*}{27600} & 1965 & $U B C$ \\
\hline & 1925 & NO \\
\hline & 1921 & NO \\
\hline & 1925 & NO \\
\hline & 1808 & NU \\
\hline
\end{tabular}

$\begin{array}{lll}0.000 & S T & I R \\ 0.000 & R C & I R \\ 0.000 & S T & I R \\ 0.000 & R C & I R \\ 0.000 & S T & I R \\ 0.000 & R C & I R \\ 0.000 & R C & I R \\ 0.010 & S T & I R \\ 0.000 & R C & I R \\ 0.000 & S T & I R \\ 0.000 & S T & I R \\ 0.000 & R C & I R \\ 0.000 & R C & I R \\ 0.000 & R C & I R \\ 0.000 & R C & I R \\ 0.000 & \text { IT } & I R \\ 0.000 & R C & I R \\ 0.000 & R C & I R \\ 0.048 & S T & I R \\ 0.075 & R C & R G \\ 0.000 & R C & I R \\ 0.067 & S T & R G \\ 0.083 & S T & I R \\ 0.000 & S T & I R \\ 0.000 & U M & I R \\ 0.000 & R C & I R \\ 0.000 & R C & I R \\ 0.000 & R C & I R \\ 0.000 & R C & I R \\ 0.000 & R C & I R \\ 0.000 & S T & I R \\ 0.000 & U M & I R \\ 0.052 & S T & I R \\ 0.000 & S T & I R \\ 0.036 & S T & I R \\ 0.000 & S T & I R \\ 0.066 & S T & I R \\ 0.000 & R C & I R \\ 0.000 & R C & I R \\ 0.066 & R C & R G \\ 0.064 & S T & I R \\ 0.000 & O T & I R \\ 0.000 & R C & I R \\ 0.000 & S T & I R \\ 0.000 & S T & I R \\ & & \end{array}$

500000
241250
3375000
1250000
1341250
3500000
30000

1875000
25920000
14400000
15160000
16
1690000000
1625000
1369000
3600000
6340000

1690000

0.14508

0.00000

0.00006

0.01200

0.00000

0.02610

0.00000

0.00000

0.00571

0.00000

0.00000

0.00000

0.00000

0.00000

0.00000

0.01016

0.00000

0.00000

0.00000

(

0.00000

0.00000

0.00000

0.00000

0.00590

0.00233

0.00031

0.06154

0.00146

0.00059

0.00000

0.00063

0.00000

0.00000

0.00000
0.00000

0.00000

0.00000

0.00000

0.00000 

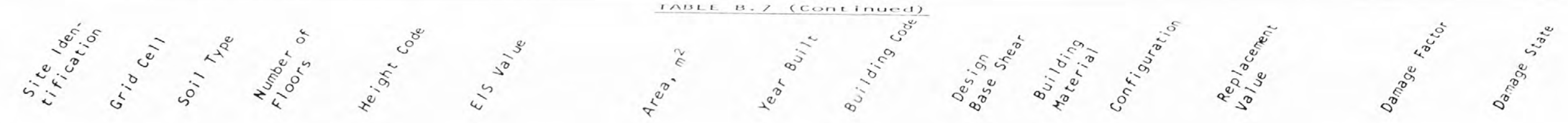

\begin{tabular}{|c|c|c|}
\hline 855 & EO6 & 8 \\
\hline 856 & EOb & 6 \\
\hline 857 & EOO & 6 \\
\hline 858 & EOb & 9 \\
\hline 859 & E06 & 9 \\
\hline 860 & EOB & 6 \\
\hline 861 & 006 & 8 \\
\hline 862 & 006 & 20 \\
\hline 863 & 005 & 12 \\
\hline 864 & 006 & 6 \\
\hline 865 & 006 & 6 \\
\hline 866 & EOb & 9 \\
\hline 867 & EOb & 7 \\
\hline 868 & $\mathrm{CO} 4$ & 7 \\
\hline 869 & 005 & 11 \\
\hline 870 & CO8 & 6 \\
\hline 871 & EO6 & 8 \\
\hline 872 & EO6 & 6 \\
\hline 873 & EOB & 8 \\
\hline 874 & EO6 & 6 \\
\hline 875 & EOO & 6 \\
\hline 876 & EOG & 6 \\
\hline 877 & EO6 & 13 \\
\hline 878 & EOG & 12 \\
\hline 879 & EO6 & 6 \\
\hline 880 & EO6 & 7 \\
\hline 881 & EO6 & 11 \\
\hline 882 & EO6 & 9 \\
\hline 883 & EO6 & 12 \\
\hline 884 & EOG & 9 \\
\hline 885 & 005 & 14 \\
\hline 886 & 005 & 14 \\
\hline 887 & EO6 & 7 \\
\hline 888 & EOG & 20 \\
\hline 889 & E06 & 8 \\
\hline 890 & EO6 & 6 \\
\hline 891 & EO6 & 7 \\
\hline 892 & EOG & 6 \\
\hline 893 & EO6 & 14 \\
\hline 894 & EO6 & 6 \\
\hline 895 & EOB & 6 \\
\hline 896 & EO6 & 10 \\
\hline 897 & EO6 & 12 \\
\hline 898 & EO6 & 7 \\
\hline
\end{tabular}

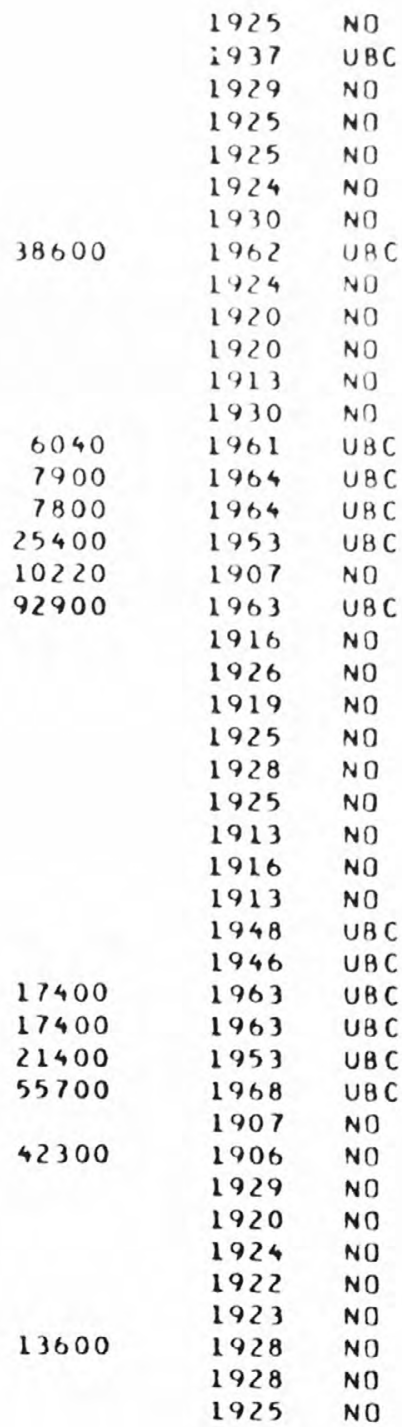

$\begin{array}{lll}0.000 & R C & I R \\ 0.010 & R C & I R \\ 0.000 & R C & I R \\ 0.000 & S T & I R \\ 0.000 & S T & I R \\ 0.000 & R C & I R \\ 0.000 & S T & I R \\ 0.055 & S T & R G \\ 0.000 & R C & I R \\ 0.000 & S T & I R \\ 0.000 & S T & I R \\ 0.000 & R C & I R \\ 0.000 & R C & I R \\ 0.052 & S T & I R \\ 0.007 & R C & I R \\ 0.083 & S T & I R \\ 0.048 & R C & I R \\ 0.000 & R C & I R \\ 0.075 & R C & R G \\ 0.000 & R C & I R \\ 0.000 & R C & I R \\ 0.000 & R C & I R \\ 0.000 & R C & I R \\ 0.000 & R C & I R \\ 0.000 & R C & I R \\ 0.000 & R C & I R \\ 0.000 & R C & I R \\ 0.000 & R C & I R \\ 0.036 & R C & I R \\ 0.044 & R C & I R \\ 0.062 & S T & R G \\ 0.062 & S T & R G \\ 0.052 & R C & I R \\ 0.055 & R C & I R \\ 0.000 & U M & I R \\ 0.000 & U M & I R \\ 0.000 & R C & I R \\ 0.000 & U M & I R \\ 0.000 & R C & I R \\ 0.000 & R C & I R \\ 0.000 & R C & I R \\ 0.000 & R C & I R \\ 0.000 & R C & I R \\ 0.000 & S T & I R \\ & & \end{array}$

0.00000

0.00000

0.00000

0.00000

0.00000

0.00000

11500000

0.00000

0.00377

0.00000

0.00000

0.00000

5853000

2700000

0.01025

0.00390

9420000

0.00000

2750000

0.00000

30690000

0.00000

0.00000

0.00000

0.00000

0.00000

0.00000

0.00000

0.00000

0.00000

0.00000

0.00000

4980000

0.00000

4980000

0.00000

0.02283

0.00000

0.00000

11385000

0.00445

0.00000

0.00000

0.00000
0.00000

0.00000

0.01323

3650000

0.00000

0.00000 

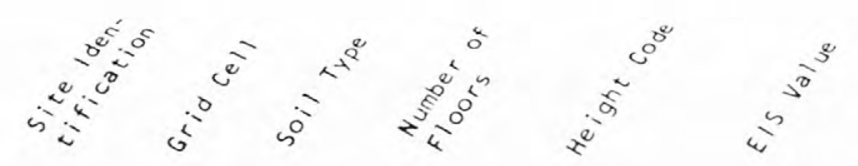

\begin{tabular}{|c|c|}
\hline 899 & 006 \\
\hline 900 & 102 \\
\hline 901 & 102 \\
\hline 902 & 006 \\
\hline 903 & 006 \\
\hline 904 & 006 \\
\hline 905 & 006 \\
\hline 906 & EO6 \\
\hline 907 & EO6 \\
\hline 908 & 807 \\
\hline 909 & EO6 \\
\hline 910 & EO6 \\
\hline 911 & EO6 \\
\hline 912 & $E 06$ \\
\hline 913 & EOG \\
\hline 914 & EOS \\
\hline 915 & EOG \\
\hline 916 & EOB \\
\hline 917 & $E O B$ \\
\hline 918 & EOS \\
\hline 919 & EO6 \\
\hline 920 & EOB \\
\hline 921 & E06 \\
\hline 922 & EO6 \\
\hline 923 & E06 \\
\hline 924 & EO6 \\
\hline 925 & 806 \\
\hline 926 & 005 \\
\hline 927 & 006 \\
\hline 928 & 006 \\
\hline 929 & DOA \\
\hline 930 & EO6 \\
\hline 931 & EOB \\
\hline 032 & EOG \\
\hline 933 & 006 \\
\hline 934 & D06 \\
\hline 935 & E06 \\
\hline 936 & 804 \\
\hline 937 & 807 \\
\hline 938 & DOS \\
\hline 939 & 005 \\
\hline 940 & 005 \\
\hline 941 & 006 \\
\hline 942 & EOB \\
\hline
\end{tabular}
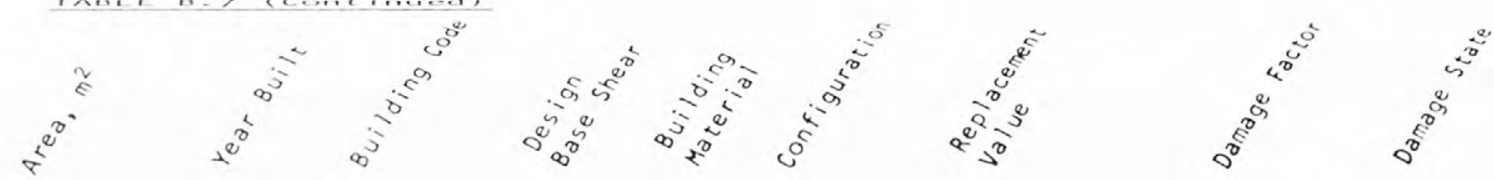

$\begin{array}{lll}28800 & 1963 & \text { UBC } \\ 13630 & 1962 & \text { UBC } \\ & 1964 & \text { UBC } \\ & 1920 & \text { NO } \\ & 1928 & \text { NO } \\ & 1920 & \text { NO } \\ & 1920 & \text { NO } \\ & 1920 & \text { NO } \\ 12100 & 1965 & \text { UBC } \\ 13800 & 1964 & \text { UBC } \\ & 1929 & \text { NO } \\ & 1920 & \text { NO } \\ & 1923 & \text { NO } \\ & 1925 & \text { NO } \\ & 1924 & \text { NO } \\ & 1927 & \text { NO } \\ 27900 & 1967 & \text { UBC } \\ & 1928 & \text { NO } \\ 6500 & 1913 & \text { NO } \\ & 1922 & \text { NO } \\ & 1922 & \text { NO } \\ & 1957 & \text { UBC } \\ & 1929 & \text { NO } \\ 12300 & 1924 & \text { NO } \\ 23000 & 1925 & \text { NO } \\ & 1931 & \text { NO } \\ 2680 & 1965 & \text { UBC } \\ 11200 & 1964 & \text { UBC } \\ & 1920 & \text { NO } \\ & 1929 & \text { NO } \\ & 1920 & \text { NO } \\ & 1925 & \text { NO } \\ & 1926 & \text { NO } \\ & 1927 & \text { NO } \\ & 1915 & \text { NO } \\ & 1928 & \text { NO } \\ & 1910 & \text { NO } \\ & 1965 & \text { UBC } \\ & 1924 & \text { NO } \\ & 1940 & \text { UBC } \\ & 1928 & \text { NO } \\ & 1936 & \text { UBC } \\ & 1920 & \text { NO } \\ & 1924 & \text { NO } \\ & & \\ & 190 & \end{array}$

$\begin{array}{ll}R C & I R \\ S T & I R \\ S T & I R \\ S T & I R \\ R C & I R \\ S T & I R \\ S T & I R \\ S T & I R \\ S T & I R \\ S T & I R \\ R C & I R \\ R C & I R \\ R C & I R \\ R C & I R \\ S T & I R \\ S T & I R \\ S T & R G \\ S T & I R \\ R C & I R \\ S T & I R \\ R C & I R \\ R C & I R \\ S T & I R \\ R C & I R \\ R C & I R \\ R C & I R \\ S T & R G \\ S T & R G \\ S T & I R \\ R C & I R \\ S T & I \\ R C & I \\ R C & I R \\ R C & I R \\ R C & I R \\ R C & I R \\ R C & I R \\ S T & R C \\ R C & I R \\ R C & I R \\ R C & I R \\ R C & I R \\ S T & I R \\ U A & I R \\ & \end{array}$

10442000
3668100

3190000
3311000

13440000
1750000

3311500
6203400
2869000
3080000
116000

$\begin{array}{ll}0.00000 & 0 \\ 0.00575 & 3 \\ 0.00545 & 3 \\ 0.00000 & 0 \\ 0.00000 & 0 \\ 0.00000 & 0 \\ 0.00000 & 0 \\ 0.00000 & 0 \\ 0.00035 & 0 \\ 0.00151 & 2 \\ 0.00000 & 0 \\ 0.00000 & 0 \\ 0.00000 & 0 \\ 0.00000 & 0 \\ 0.00000 & 0 \\ 0.00000 & 0 \\ 0.00000 & 0 \\ 0.00000 & 0 \\ 0.00183 & 2 \\ 0.00000 & 0 \\ 0.00000 & 0 \\ 0.00000 & 0 \\ 0.00000 & 0 \\ 0.04022 & 5 \\ 0.00806 & 3 \\ 0.00000 & 0 \\ 0.00010 & 0 \\ 0.00000 & 0 \\ 0.00000 & 0 \\ 0.00000 & 0 \\ 0.00000 & 0 \\ 0.00000 & 0 \\ 0.00000 & 0 \\ 0.00500 & 3 \\ 0.00000 & 0 \\ 0.00000 & 0 \\ 0.00000 & 0 \\ 0.00040 & 0 \\ 0.00000 & 0 \\ 0.00000 & 0 \\ 0.00000 & 0 \\ 0.00000 & 0 \\ 0.00000 & 0 \\ 0.00000 & 0\end{array}$



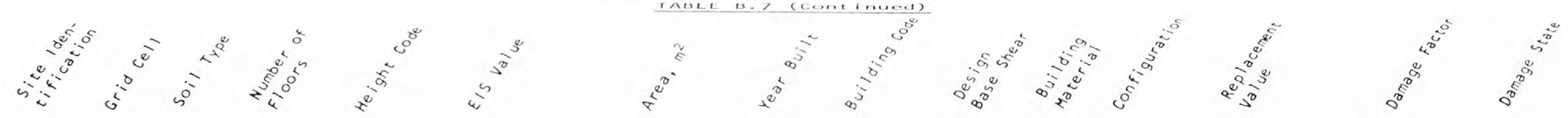

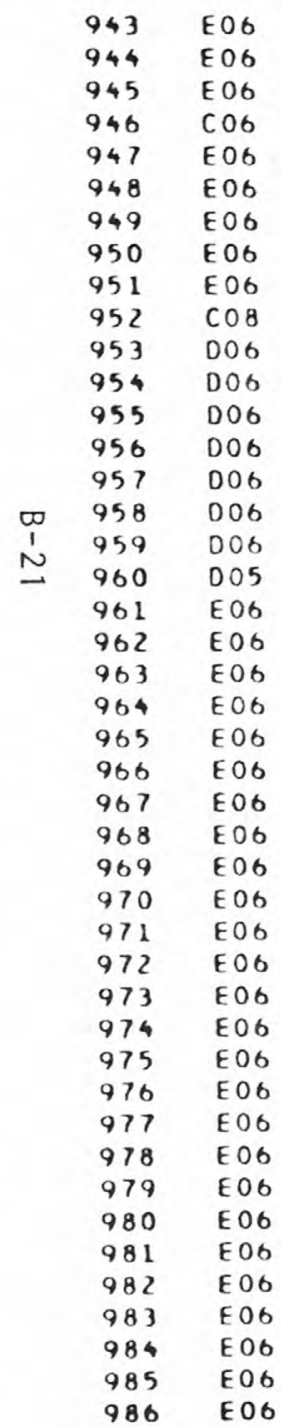

\begin{tabular}{|c|c|c|}
\hline & 1922 & NO \\
\hline & 1928 & NO \\
\hline & 1916 & N0 \\
\hline \multirow[t]{6}{*}{55700} & 1971 & UBC \\
\hline & 1918 & NO \\
\hline & 1925 & NO \\
\hline & 1926 & NO \\
\hline & 1923 & NO \\
\hline & 1928 & NO \\
\hline \multirow[t]{9}{*}{10200} & 1964 & UBC \\
\hline & 1930 & NO \\
\hline & 1920 & NO \\
\hline & 1929 & NO \\
\hline & 1929 & NO \\
\hline & 1928 & NO \\
\hline & 1929 & NO \\
\hline & 1930 & NO \\
\hline & 1930 & NO \\
\hline \multirow[t]{2}{*}{17700} & 1948 & UBC \\
\hline & 1913 & NO \\
\hline \multirow[t]{3}{*}{480} & 1956 & UBC \\
\hline & 1903 & NO \\
\hline & 1914 & NO \\
\hline 25300 & 1928 & NO \\
\hline 5270 & 1955 & UBC \\
\hline 23800 & 1929 & NO \\
\hline 16300 & 1913 & NO \\
\hline 12700 & 1913 & NO \\
\hline \multirow[t]{4}{*}{17700} & 1907 & NO \\
\hline & 1910 & NO \\
\hline & 1908 & NO \\
\hline & 1923 & NO \\
\hline 17500 & 1913 & NO \\
\hline \multirow[t]{7}{*}{26000} & 1959 & $\cup B C$ \\
\hline & 1930 & NO \\
\hline & 1923 & NO \\
\hline & 1915 & NO \\
\hline & 1930 & NO \\
\hline & 1918 & NO \\
\hline & 1930 & NO \\
\hline 12400 & 1921 & NO \\
\hline \multirow[t]{3}{*}{23400} & 1924 & NO \\
\hline & 1924 & NO \\
\hline & 1914 & NO \\
\hline
\end{tabular}

\begin{tabular}{|c|c|}
\hline 0.000 & $R C$ \\
\hline 0.000 & RC \\
\hline 0.000 & $R C$ \\
\hline 0.051 & ST \\
\hline 0.000 & $R C$ \\
\hline 0.000 & $R C$ \\
\hline 0.000 & $R C$ \\
\hline 0.000 & $2 \mathrm{C}$ \\
\hline 0.000 & RC \\
\hline 0.075 & $R C$ \\
\hline 0.000 & ST \\
\hline 0.000 & UN \\
\hline 0.000 & $R C$ \\
\hline 0.000 & RC \\
\hline 0.000 & $R C$ \\
\hline 0.000 & $R C$ \\
\hline 0.000 & $R C$ \\
\hline 0.000 & $R C$ \\
\hline 0.036 & $S T$ \\
\hline 0.000 & ST \\
\hline 0.048 & RM \\
\hline 0.000 & $S T$ \\
\hline 0.000 & $R C$ \\
\hline 0.000 & $R C$ \\
\hline 0.052 & $R C$ \\
\hline 0.000 & ST \\
\hline 0.000 & $R C$ \\
\hline 0.000 & $R C$ \\
\hline 0.000 & $R C$ \\
\hline 0.000 & ST \\
\hline 0.000 & $R C$ \\
\hline 0.000 & ST \\
\hline 0.000 & $R C$ \\
\hline 0.031 & ST \\
\hline 0.000 & $S T$ \\
\hline 0.000 & ST \\
\hline 0.000 & $R C$ \\
\hline 0.000 & ST \\
\hline 0.000 & $R C$ \\
\hline 0.000 & ST \\
\hline 0.000 & ST \\
\hline 0.000 & ST \\
\hline 0.000 & ST \\
\hline & $S T$ \\
\hline
\end{tabular}

0.00000 0.00000 0.00000 0.00000 0.00000 0.00000 0.00000 0.00000 0.00000 0.00000 0.00000 0.00000 0.00000 0.00000 0.00000 0.00000 0.00000 0.00000

8460000 0.02033 0.00000 128000 0.00000 0.00000 0.00000

6798000 1417500 6417000

4375000 .01150 0.00616 0.00546 0.05570 0.05570
0.07097 0.04435 0.00000 0.00000 0.0000 . 0.04001 0.00000 0.00000 .00000 . 00000 0.00000 0.00000 0.00906 0.08053 0.00000 0.00000 

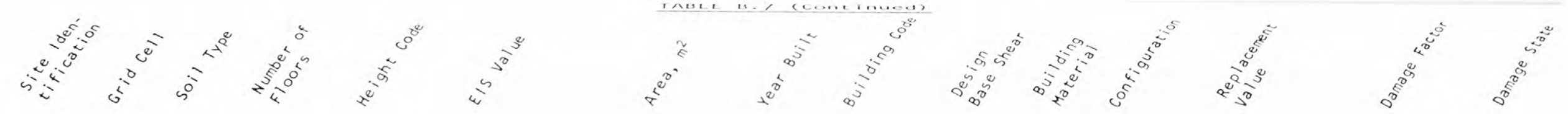

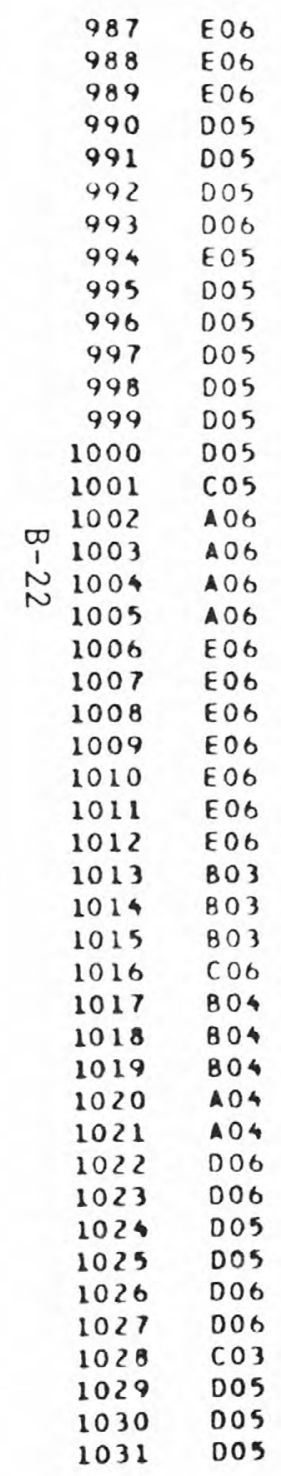

\begin{tabular}{|c|c|c|}
\hline & 1923 & NO \\
\hline \multirow[t]{5}{*}{13900} & 1923 & NO \\
\hline & 1914 & NO \\
\hline & 1920 & NO \\
\hline & 1920 & NO \\
\hline & 1920 & NI) \\
\hline 5340 & 1965 & UBC \\
\hline $11: 50$ & 1963 & $\cup B C$ \\
\hline 20700 & 1967 & $\cup B C$ \\
\hline \multirow[t]{2}{*}{9750} & 1961 & UBC \\
\hline & 1960 & UBC \\
\hline 8360 & 1964 & UBC \\
\hline \multirow[t]{3}{*}{10200} & 1964 & UBC \\
\hline & 1923 & NO \\
\hline & 1925 & NO \\
\hline 13800 & 1961 & UBC \\
\hline 13800 & 1901 & UBC \\
\hline 8400 & 1961 & UBC \\
\hline $8<00$ & 1961 & UBC \\
\hline 3720 & 1932 & NO \\
\hline 28700 & 1960 & UBC \\
\hline 67800 & 1958 & UBC \\
\hline \multirow[t]{4}{*}{81400} & 1970 & $\cup B C$ \\
\hline & 1926 & NO \\
\hline & 1920 & NO \\
\hline & 1920 & NO \\
\hline 9010 & 1963 & UBC \\
\hline 6690 & 1967 & UBC \\
\hline 13900 & 1962 & UBC \\
\hline 5570 & 1963 & UBC \\
\hline 15600 & 1970 & $\cup B C$ \\
\hline 5570 & 1968 & UBC \\
\hline 6320 & 1964 & UBC \\
\hline 22500 & 1970 & $\cup B C$ \\
\hline \multirow[t]{2}{*}{8360} & 1970 & UBC \\
\hline & 1927 & NO \\
\hline 12100 & 1965 & UBC \\
\hline \multirow[t]{3}{*}{16300} & 1925 & NO \\
\hline & 1961 & $U B C$ \\
\hline & 1915 & NO \\
\hline 6690 & 1968 & UBC \\
\hline \multirow[t]{2}{*}{1150} & 1958 & UBC \\
\hline & 1925 & NO \\
\hline \multirow{2}{*}{21800} & 1971 & UBC \\
\hline & 1924 & NO \\
\hline
\end{tabular}

0.000
0.000
0.000
0.000
0.000
0.000
0.078
0.066
0.075
0.048
0.052
0.056
0.070
0.000
0.000
0.041
0.041
0.057
0.057
0.000
0.044
0.041
0.056
0.000
0.000
0.000
0.075
0.083
0.064
0.075
0.066
0.078
0.075
0.062
0.070
0.000
0.066
0.000
0.048
0.000
0.064
0.044
0.000
0.060
0.000

$\begin{array}{ll}S T & I R \\ S T & I R \\ R C & I R \\ S T & I R \\ S T & I R \\ R C & I R \\ R C & I R \\ S T & R G \\ S T & R G \\ R C & I R \\ R C & I R \\ S T & R G \\ S T & R G \\ R C & I R \\ R C & I R \\ R C & R G \\ R C & R G \\ R C & R G \\ R C & R G \\ R C & I R \\ S T & I R \\ R C & I R \\ S T & I R \\ S T & R G \\ R C & I R \\ S T & I R \\ S T & I R \\ S T & I R \\ R C & I R \\ R C & I R \\ R C & I R \\ S T & I R \\ R C & R G \\ R C & R G \\ R C & I R \\ R C & R G \\ R C & R G \\ R C & I R \\ R C & I R \\ R C & I R \\ R C & I R \\ R C & I R \\ R C & I R \\ S T & R G \\ R C & I R \\ S T & R G \\ R C & I R \\ & \\ S C & \end{array}$

375000

0.00000

0.00667

0.00000

0.00000

0.00000

0.00000

0206400

4470000

0.0161

0.00000

$4900000 \quad 0.00100$

4590000

0.00100

3500000

0.00738

0.00000

0.00000

2250000

2250000

0.00000

0.00000

0.00000

1476000

1000000

0.00000

0.03000

0.00000

16740000

0.00454

0.00000

0.00000

0.00501

4930000

1825600

0.02301

2450000

0.00042

0.00000

2122200

0.00000

0.00770

6056800

1700000

0.00000

5390000

0.00000

4375000

0.00000

0.01143

0.00000

0.00000

2160000

0.00665

540000

0.00000

(20000

0.00000

0
3
0
0
0
0
4
0
1
0
0
1
3
0
0
0
0
0
0
4
0
3
0
0
0
0
3
4
5
0
0
0
3
0
0
0
0
4
0
0
3
0
0
0
0



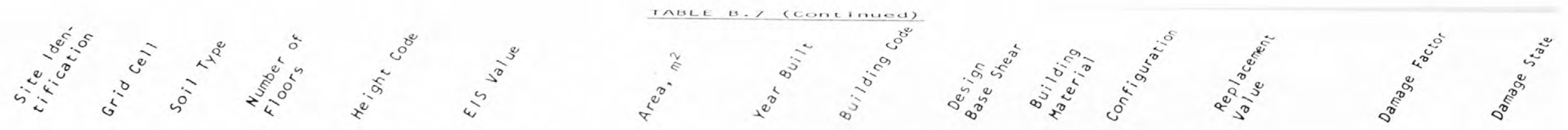

\begin{tabular}{|c|c|}
\hline 1032 & 005 \\
\hline 1033 & EOG \\
\hline 1034 & B 07 \\
\hline 1035 & 006 \\
\hline 1036 & D05 \\
\hline 1037 & 005 \\
\hline 1038 & EO6 \\
\hline 1039 & 006 \\
\hline 1040 & D05 \\
\hline 1041 & D05 \\
\hline 1042 & B 07 \\
\hline 1043 & 005 \\
\hline 1044 & EO6 \\
\hline 1045 & EO6 \\
\hline 1046 & EO6 \\
\hline 1047 & $E O 6$ \\
\hline 1048 & EO6 \\
\hline 1049 & EOB \\
\hline 1050 & EOO \\
\hline 1051 & EO6 \\
\hline 1052 & EOG \\
\hline 1053 & EOB \\
\hline 1054 & EO6 \\
\hline 1055 & EO6 \\
\hline 1056 & EO6 \\
\hline 1057 & EO6 \\
\hline 1058 & EO6 \\
\hline 1059 & E06 \\
\hline 1060 & EO6 \\
\hline 1061 & EO6 \\
\hline 1062 & $E 06$ \\
\hline 1063 & 006 \\
\hline 1064 & DOG \\
\hline 1065 & 006 \\
\hline 1066 & 006 \\
\hline 1067 & 006 \\
\hline 1068 & DO6 \\
\hline 1009 & 006 \\
\hline 1070 & D06 \\
\hline 1071 & 006 \\
\hline 1072 & 006 \\
\hline 1073 & 006 \\
\hline 1074 & 006 \\
\hline 1075 & 006 \\
\hline
\end{tabular}

\begin{tabular}{|c|c|c|}
\hline \multirow[t]{2}{*}{9100} & 1956 & $\cup B C$ \\
\hline & 1924 & NO \\
\hline \multirow[t]{7}{*}{10900} & 1969 & $\cup B C$ \\
\hline & 1926 & NO \\
\hline & 1925 & NO \\
\hline & 1928 & NO \\
\hline & 1924 & NO \\
\hline & 1960 & UBC \\
\hline & 1930 & NO \\
\hline 5760 & 1926 & NO \\
\hline 6260 & 1971 & UBC \\
\hline 31300 & 1961 & $U B C$ \\
\hline 15800 & 1953 & UBC \\
\hline 17800 & 1965 & U8C \\
\hline 6970 & 1966 & $\cup B C$ \\
\hline 21100 & 1970 & UBC \\
\hline \multirow[t]{2}{*}{13900} & 1951 & UBC \\
\hline & 1912 & NO \\
\hline 17200 & 1960 & UBC \\
\hline \multirow[t]{2}{*}{16400} & 1964 & $\cup B C$ \\
\hline & 1964 & $\cup 8 C$ \\
\hline 11400 & 1959 & U BC \\
\hline 9290 & 1964 & UBC \\
\hline \multirow[t]{3}{*}{10220} & 1928 & NO \\
\hline & 1923 & NO \\
\hline & 1951 & UBC \\
\hline \multirow[t]{3}{*}{12100} & 1961 & UBC \\
\hline & 1923 & NO \\
\hline & 1959 & UBC \\
\hline \multirow[t]{4}{*}{14100} & 1926 & NO \\
\hline & 1911 & NO \\
\hline & 1928 & NO \\
\hline & 1957 & UBC \\
\hline 12400 & 1963 & UBC \\
\hline \multirow[t]{2}{*}{21400} & 1961 & UBC \\
\hline & 1956 & U8C \\
\hline \multirow[t]{2}{*}{38600} & 1968 & UBC \\
\hline & 1924 & NO \\
\hline 15800 & 1971 & U8C \\
\hline 18700 & 1955 & $U B C$ \\
\hline \multirow[t]{3}{*}{16700} & 1957 & UBC \\
\hline & 1924 & NO \\
\hline & 1920 & NO \\
\hline 18000 & 1958 & UBC \\
\hline
\end{tabular}

$\begin{array}{lll}0.034 & S T & I R \\ 0.000 & R C & I R \\ 0.067 & R C & R G \\ 0.000 & R C & I R \\ 0.000 & R C & I R \\ 0.000 & R C & I R \\ 0.000 & R C & R G \\ 0.057 & R C & R G \\ 0.000 & S T & I R \\ 0.000 & S T & I R \\ 0.067 & S T & R G \\ 0.034 & R C & I R \\ 0.034 & S T & I R \\ 0.067 & R C & R G \\ 0.083 & R C & R G \\ 0.060 & S T & R G \\ 0.031 & S T & I R \\ 0.000 & R C & I R \\ 0.031 & S T & I R \\ 0.061 & S T & I R \\ 0.083 & R C & I R \\ 0.048 & R C & I R \\ 0.075 & R C & R G \\ 0.000 & S T & I R \\ 0.000 & R C & I R \\ 0.041 & S T & R G \\ 0.036 & R C & R G \\ 0.000 & R C & I R \\ 0.057 & S T & I R \\ 0.000 & R C & I R \\ 0.000 & S T & I R \\ 0.000 & R C & I R \\ 0.057 & S T & R G \\ 0.072 & R C & I R \\ 0.032 & S T & I R \\ 0.057 & R C & I R \\ 0.054 & S T & R C \\ 0.000 & R C & I R \\ 0.066 & R C & R G \\ 0.034 & R C & R G \\ 0.036 & S T & I R \\ 0.000 & R C & I R \\ 0.000 & R C & I R \\ 0.034 & S T & R G \\ & & \end{array}$

2022000

1685000

9020000

9270000

2362000

6780000

7990000

8112000

8470000

4140000

4130000

2750000

7570000

3298000

.

4890000

11180000

13560000

4520000

5910000

6140000

8370000
0.00392 0.00000

0.00000 0.00000 0.00000 0.00000 0.00000 0.00000 0.00000 0.00613 0.00000 0.02055 0.00000 0.00050 0.00106 .00000 0.00000 0.00000 0.00105

0.00114 0.00000 .00000 0.00551 0.00309 0.00000 0.00000 0.00078 0.00000 0.00000 0.21225 0.00000 .00000 0.00000 .00327 .00235 0.00000 0.00000 0.00000 .00069 0.00000 0.00000 0.00000 0.00000 0.00123 

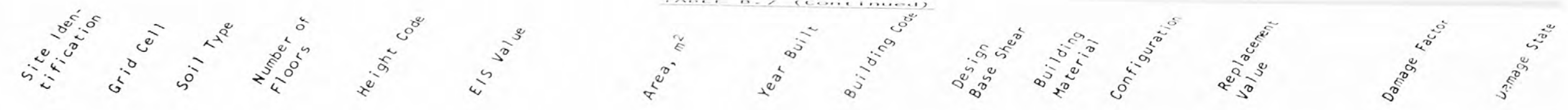

$\begin{array}{ll}1076 & 006 \\ 1077 & 006 \\ 1078 & 006 \\ 1079 & 006 \\ 1080 & 006 \\ 1081 & 006 \\ 1082 & 006 \\ 1083 & 006 \\ 1084 & E 06 \\ 1085 & 006 \\ 1086 & 006 \\ 1087 & 006 \\ 1088 & 006 \\ 1089 & 006 \\ 1090 & 006 \\ 1091 & 006 \\ 1092 & 006 \\ 1092 \\ 1093 & 006 \\ 1094 & 006 \\ 1095 & 006 \\ 1096 & 006 \\ 1097 & 006 \\ 1098 & 006 \\ 1099 & 006 \\ 1100 & 606 \\ 1101 & C 06 \\ 1102 & C 06 \\ 1103 & C 06 \\ 1104 & C 06 \\ 1105 & C 06 \\ 1106 & C 06 \\ 1107 & 606 \\ 1108 & 006 \\ 1109 & C 06 \\ 1110 & C 06 \\ 1111 & 806 \\ 1112 & 806 \\ 1113 & 806 \\ 1114 & 806 \\ 1115 & 806 \\ 1116 & 806 \\ 1117 & 806 \\ 1118 & 806 \\ 1119 & 806 \\ 1120 & 806 \\ 11 & \end{array}$

$\begin{array}{lll}15700 & 1950 & \text { UBC } \\ 15700 & 1950 & \text { UBC } \\ 15700 & 1950 & \text { UBC } \\ & 1965 & \text { UBC } \\ 19000 & 1955 & \text { UBC } \\ 42500 & 1961 & \text { UBC } \\ 30700 & 1966 & \text { UBC } \\ 37500 & 1969 & \text { UBC } \\ & 1969 & \text { UBC } \\ & 1931 & \text { NO } \\ 13900 & 1967 & \text { UBC } \\ 33070 & 1963 & \text { UBC } \\ 7430 & 1929 & \text { NO } \\ & 1959 & \text { UBC } \\ & 1962 & \text { UBC } \\ 10870 & 1963 & \text { UBC } \\ 32500 & 1958 & \text { UBC } \\ 11150 & 1949 & \text { UBC } \\ & 1930 & \text { NO } \\ 5500 & 1929 & \text { NO } \\ 19500 & 1960 & \text { UBC } \\ & 1929 & \text { NO } \\ 43600 & 1963 & \text { UBC } \\ 50000 & 1948 & \text { UBC } \\ 39500 & 1959 & \text { UBC } \\ & 1939 & \text { UBC } \\ 36000 & 1957 & \text { UBC } \\ 1971 & \text { UBC } \\ 14900 & 1964 & \text { UBC } \\ 9290 & 1952 & \text { UBC } \\ 19000 & 1964 & \text { UBC } \\ 17900 & 1970 & \text { UBC } \\ 10200 & 1956 & \text { UBC } \\ 18670 & 1950 & \text { UBC } \\ 24160 & 1962 & \text { UBC } \\ 27600 & 1960 & \text { UBC } \\ 37800 & 1962 & \text { UBC } \\ 6300 & 1960 & \text { UBC } \\ 18500 & 1963 & \text { UBC } \\ 14400 & 1956 & \text { UBC } \\ 19200 & 1960 & \text { UBC } \\ & 1970 & \text { UBC } \\ & 1962 & \text { UBC }\end{array}$

0.036
0.036
0.036
0.066
0.034
0.029
0.067
0.067
0.067
0.000
0.066
0.054
0.000
0.052
0.083
0.072
0.057
0.036
0.000
0.000
0.029
0.000
0.050
0.039
0.057
0.010
0.052
0.054
0.052
0.057
0.060
0.039
0.066
0.056
0.036
0.039
0.061
0.034
0.053
0.057
0.053
0.036
0.032
0.052
0.061

$\begin{array}{ll}S T & R G \\ S T & R G \\ S T & R G \\ R C & I R \\ S T & I R \\ S T & I R \\ \text { RC } & R G \\ R C & R G \\ R C & R G \\ \text { ST } & I R \\ R C & R G \\ S T & R G \\ S T & R G \\ S T & R G \\ S T & R G \\ R C & R G \\ S T & R G \\ S T & R G \\ S T & R G \\ R C & R G \\ R C & R G \\ S T & R G \\ R C & R G \\ S T & R G \\ R C & R G \\ S T & I R \\ S T & I R \\ S C & I R \\ R C & I R \\ S T & R G \\ S T & I R \\ R C & I R \\ S T & R G \\ R C & I R \\ R C & R G \\ S T & R G \\ S T & I R \\ S C & R G \\ R T & R T \\ S T & R G \\ R C & R G \\ S T & R G \\ R C & I R \\ S T & R G \\ R C & I R \\ S T & R G \\ S T & I R \\ S T & R G \\ & \\ S G\end{array}$

4200000

4200000

4200000

5630000

20800000

15100000

20960000

5290000

15910000

2000000

3770000

10230000

3220000

1480000

10320000

19080000

13700000

15100000

14700000

6360000

3290000

2770000

7460000
4020000

3024000

7660000

7660000

12500000

12500000
161000

8750000

3650000

5410000

22400000

14430000
0.00000

0.00000

0.01512

0.00000

0.00207

0.00381

0.00129

0.00000

0.00000

0.00000

0.00092

0.00650

0.00900

0.00000

0.00000

0.01056

0.00122

0.00031

0.00000

0.00034

0.00197

0.00000

.00000

0.01329

0.00000

0.00000

0.00000

0.00000

0.00000

0.00000

0.00097

0.00316

0.00050

0.00000

0.00258

0000

0.00000

0.00000

0.00150

0.00000

0.00723

0.00000

0.00029

0.00000 

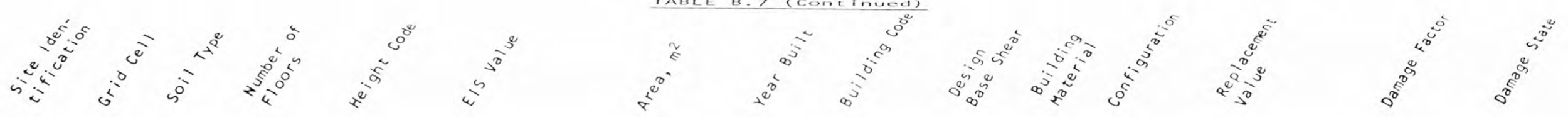

$\begin{array}{ll}1121 & 806 \\ 1122 & 806 \\ 1123 & B 06 \\ 1124 & 806 \\ 1125 & 806 \\ 1126 & 806 \\ 1127 & 806 \\ 1128 & 806 \\ 1129 & E 06 \\ 1130 & 005 \\ 1131 & F 06 \\ 1132 & C 06 \\ 1133 & C 06 \\ 1134 & C 06 \\ 1135 & C 06 \\ 1136 & C 05 \\ 1137 & C 05 \\ 1138 & C 06 \\ 11139 & C 06 \\ 11140 & C 06 \\ 1111 & C 06 \\ 1142 & C 06 \\ 1143 & C 06 \\ 1144 & C 06 \\ 1145 & C 06 \\ 1146 & C 06 \\ 1147 & C 06 \\ 1148 & C 06 \\ 1149 & C 06 \\ 1150 & C 06 \\ 1151 & C 06 \\ 1152 & C 06 \\ 1153 & C 06 \\ 1154 & C 06 \\ 1155 & C 06 \\ 1156 & C 06 \\ 1157 & C 06 \\ 1158 & C 06 \\ 1159 & C 06 \\ 1160 & C 06 \\ 1161 & C 06 \\ 1162 & C 06 \\ 1163 & C 06 \\ 1164 & C 06 \\ 1165 & C 06 \\ 11 & \\ 1150\end{array}$

\begin{tabular}{|c|c|}
\hline 22300 & 1961 \\
\hline 3250 & 1958 \\
\hline 11900 & 1962 \\
\hline 58100 & 1969 \\
\hline 27800 & 1960 \\
\hline 27800 & 1960 \\
\hline 42300 & 1960 \\
\hline 48800 & 1971 \\
\hline 3900 & 1920 \\
\hline \multirow[t]{4}{*}{3700} & 1930 \\
\hline & 1968 \\
\hline & 1961 \\
\hline & 1928 \\
\hline \multirow[t]{3}{*}{5600} & 1964 \\
\hline & 1960 \\
\hline & 1932 \\
\hline 16400 & 1962 \\
\hline \multirow[t]{4}{*}{21200} & 1962 \\
\hline & 1930 \\
\hline & 1956 \\
\hline & 1960 \\
\hline 8550 & 1954 \\
\hline 5570 & 1964 \\
\hline 19400 & 1962 \\
\hline 20400 & 1970 \\
\hline 9290 & 1963 \\
\hline 4270 & 1970 \\
\hline \multirow[t]{2}{*}{18000} & 1966 \\
\hline & 1941 \\
\hline 40000 & 1969 \\
\hline 7900 & 1959 \\
\hline \multirow[t]{2}{*}{12100} & 1969 \\
\hline & 1959 \\
\hline \multirow[t]{2}{*}{5850} & 1964 \\
\hline & 1960 \\
\hline \multirow[t]{2}{*}{19900} & 1971 \\
\hline & 1929 \\
\hline 13900 & 1968 \\
\hline 7900 & 1959 \\
\hline \multirow[t]{3}{*}{20400} & 1960 \\
\hline & 1927 \\
\hline & 1950 \\
\hline \multirow[t]{3}{*}{14900} & 1970 \\
\hline & 1939 \\
\hline & 1947 \\
\hline
\end{tabular}

$\begin{array}{lll}0.036 & S T & R G \\ 0.052 & S T & R G \\ 0.066 & S T & R G \\ 0.058 & S I & I R \\ 0.031 & S T & R G \\ 0.031 & S T & R G \\ 0.028 & S T & R G \\ 0.053 & S I & R G \\ 0.000 & R C & I R \\ 0.000 & R C & I R \\ 0.078 & R C & R G \\ 0.048 & R C & I R \\ 0.000 & U M & I R \\ 0.078 & S T & I R \\ 0.052 & S T & R G \\ 0.000 & S T & I R \\ 0.064 & S T & R G \\ 0.062 & R C & R G \\ 0.000 & R C & I R \\ 0.057 & S T & I R \\ 0.057 & R C & R G \\ 0.048 & S I & I R \\ 0.075 & R C & R G \\ 0.078 & S T & R G \\ 0.070 & R C & R G \\ 0.072 & R C & R G \\ 0.070 & R C & R G \\ 0.075 & R C & I R \\ 0.010 & R C & I R \\ 0.070 & R C & R G \\ 0.044 & S T & R G \\ 0.070 & R C & R G \\ 0.052 & R C & I R \\ 0.083 & R C & I R \\ 0.048 & R C & I R \\ 0.066 & S T & R G \\ 0.000 & S T & I R \\ 0.070 & R C & R G \\ 0.048 & R C & I R \\ 0.041 & S T & I R \\ 0.000 & S T & I R \\ 0.057 & R C & I R \\ 0.070 & R C & R G \\ 0.010 & R C & I R \\ 0.048 & R C & I R \\ 0 & & \end{array}$

$\begin{array}{rr}6000000 & 0.00000 \\ 875000 & 0.00000 \\ 5070000 & 0.00016 \\ 21000000 & 0.00278 \\ 7980000 & 0.00000 \\ 7980000 & 0.00000 \\ 12680000 & 0.00000 \\ 17000000 & 0.00000 \\ 1050000 & 0.01581 \\ 1000000 & 0.00000 \\ & 0.00000 \\ & 0.00000 \\ 2310000 & 0.00000 \\ & 0.00433 \\ 5710000 & 0.00000 \\ 4890000 & 0.00000 \\ & 0.00000 \\ & 0.00000 \\ 2810000 & 0.00000 \\ 3080000 & 0.000049 \\ 5216000 & 0.00000 \\ 12400000 & 0.00000 \\ 5090000 & 0.00000 \\ 1350000 & 0.00000 \\ 5000000 & 0.00130 \\ 12000000 & 0.00000 \\ 4300000 & 0.00000 \\ 2600000 & 0.00030 \\ 1575000 & 0.00000 \\ & 0.01333 \\ 5090000 & 0.00000 \\ & 0.00000 \\ 6550000 & 0.00000 \\ 3960000 & 0.00000 \\ 7540000 & 0.00000 \\ & 0.00000 \\ 4520000 & 0.00000 \\ & 0.00000 \\ & 0.00000 \\ & 0.00000 \\ & 0.00000\end{array}$



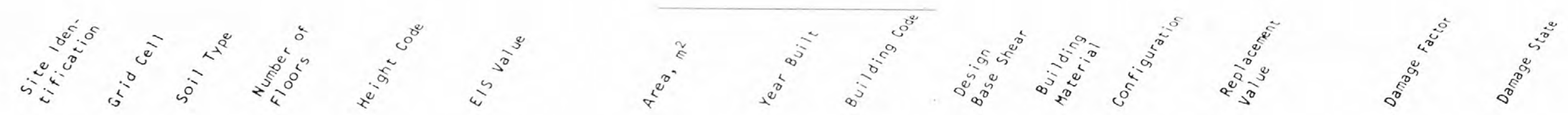

\begin{tabular}{|c|c|}
\hline 1166 & $\mathrm{COB}$ \\
\hline 1167 & $\mathrm{COO}$ \\
\hline 1168 & $\mathrm{COB}$ \\
\hline 1169 & $\mathrm{COO}$ \\
\hline 1170 & $\mathrm{COB}$ \\
\hline 1171 & $\mathrm{COB}$ \\
\hline 1172 & $\mathrm{COB}$ \\
\hline 1173 & $\cos$ \\
\hline 1174 & $\cos$ \\
\hline 1175 & 009 \\
\hline 1176 & $\mathrm{COB}$ \\
\hline 1177 & CO8 \\
\hline 1178 & COB \\
\hline 1179 & $\mathrm{COS}$ \\
\hline 1180 & $\cos$ \\
\hline 1181 & $\cos$ \\
\hline 1182 & COS \\
\hline 1183 & $\cos$ \\
\hline 1184 & C05 \\
\hline 1185 & $\cos$ \\
\hline 1186 & COS \\
\hline 1187 & C05 \\
\hline 1188 & $\cos$ \\
\hline 1189 & $\mathrm{COS}$ \\
\hline 1190 & COS \\
\hline 1191 & $C 05$ \\
\hline 1192 & C09 \\
\hline 1193 & $A 06$ \\
\hline 1194 & 807 \\
\hline 1195 & $A 06$ \\
\hline 1196 & $A 06$ \\
\hline 1197 & $A 06$ \\
\hline 1198 & 807 \\
\hline 1199 & 807 \\
\hline 1200 & 807 \\
\hline 1201 & 807 \\
\hline 1202 & 806 \\
\hline 1203 & $A 06$ \\
\hline 1204 & 806 \\
\hline 1205 & 806 \\
\hline 1206 & 807 \\
\hline 1207 & 807 \\
\hline 1208 & 807 \\
\hline 1209 & $A 06$ \\
\hline 1210 & $A 06$ \\
\hline
\end{tabular}

\begin{tabular}{|c|c|c|c|c|}
\hline 8 & 1 & 27900 & 1961 & UBC \\
\hline 8 & 1 & 6500 & 1962 & UBC \\
\hline 8 & 1 & 11150 & 1965 & UBC \\
\hline 8 & 1 & & 1955 & UBC \\
\hline 15 & 2 & 31500 & 1970 & UBC \\
\hline 8 & 1 & 11300 & 1963 & UBC \\
\hline 12 & 2 & 11000 & 1965 & UBC \\
\hline 11 & 2 & 23800 & 1971 & UBC \\
\hline 8 & 1 & 11150 & 1961 & UBC \\
\hline 6 & 1 & 15800 & 1964 & UAC \\
\hline 12 & 2 & 22300 & 1962 & UBC \\
\hline 8 & 1 & 9750 & 1961 & $U A C$ \\
\hline 8 & 1 & 11300 & 1901 & $U B C$ \\
\hline 16 & 2 & 32100 & 1965 & $U B C$ \\
\hline 13 & 2 & 13100 & 1960 & $\cup B C$ \\
\hline 30 & 3 & 48600 & 1963 & UHC \\
\hline 13 & 2 & 33900 & 1963 & UBC \\
\hline 13 & 2 & 22300 & 1963 & UBC \\
\hline 12 & 2 & & 1938 & $\cup B C$ \\
\hline 13 & 2 & 23400 & 1961 & UAC \\
\hline 10 & 2 & 13000 & 1963 & UBC \\
\hline 14 & 2 & 13010 & 1965 & UBC \\
\hline 13 & 2 & 22900 & 1970 & UBC \\
\hline 9 & 2 & 9290 & 1963 & UBC \\
\hline 9 & 2 & 9290 & 1960 & $U B C$ \\
\hline 11 & 2 & 14800 & 1961 & $\cup B C$ \\
\hline 10 & 2 & 13300 & 1966 & UBC \\
\hline 17 & 2 & 16300 & 1964 & $\cup B C$ \\
\hline 8 & 1 & & 1928 & NO \\
\hline 13 & 2 & 16800 & 1962 & U8C \\
\hline 13 & 2 & 15100 & 1962 & UBC \\
\hline 21 & 3 & 24600 & 1970 & UBC \\
\hline 8 & 1 & 6020 & 1932 & NO \\
\hline 15 & 2 & 28600 & 1964 & UAC \\
\hline 10 & 2 & 7150 & 1961 & $\cup B C$ \\
\hline 13 & 2 & 3530 & 1929 & NO \\
\hline 7 & 1 & 10000 & 1964 & UBC \\
\hline 8 & 1 & 6000 & 1969 & UBC \\
\hline 9 & 2 & 8200 & 1961 & $U B C$ \\
\hline 6 & 1 & 8300 & 1969 & UBC \\
\hline 17 & 2 & 39900 & 1964 & UBC \\
\hline 17 & 2 & 39900 & 1964 & UBC \\
\hline 8 & 1 & 6330 & 1968 & UBC \\
\hline 9 & 2 & 17300 & 1962 & $U B C$ \\
\hline 16 & 2 & 22300 & 1970 & $U B C$ \\
\hline
\end{tabular}

$\begin{array}{lll}0.048 & S T & R G \\ 0.075 & R C & I R \\ 0.075 & R C & R G \\ 0.048 & R C & I R \\ 0.061 & S T & R G \\ 0.075 & S T & R G \\ 0.066 & S T & R G \\ 0.067 & S T & R G \\ 0.048 & S T & R G \\ 0.083 & S T & R G \\ 0.066 & S T & R G \\ 0.048 & S T & R G \\ 0.048 & R C & R G \\ 0.060 & S T & I R \\ 0.034 & S T & R G \\ 0.048 & S T & R G \\ 0.064 & R C & R G \\ 0.064 & S T & R G \\ 0.010 & R C & I R \\ 0.034 & S T & R G \\ 0.070 & R C & R G \\ 0.062 & S T & R G \\ 0.064 & S T & R G \\ 0.072 & R C & R G \\ 0.044 & S T & R G \\ 0.039 & S T & R G \\ 0.070 & R C & R G \\ 0.058 & S T & R G \\ 0.000 & R C & R G \\ 0.064 & R C & R G \\ 0.064 & R C & R G \\ 0.054 & S T & R G \\ 0.000 & S T & I R \\ 0.061 & S T & R G \\ 0.041 & R C & R G \\ 0.000 & R C & I R \\ 0.078 & S T & R G \\ 0.075 & R C & R G \\ 0.044 & S T & I R \\ 0.083 & R C & R G \\ 0.058 & S T & R G \\ 0.058 & S T & R G \\ 0.075 & S T & R G \\ 0.072 & R C & R G \\ 0.060 & S T & R G \\ 0 & & \\ 0.06 & & R G\end{array}$

13940000
2460000
4770000
7460000
2930000
4530000
6600000
2460000
1924000
8150000
2623000
2460000
7550000
4230000
9540000
6840000
4770000
155000
3770000
2450000
4290000
8140000
3260000
5920000
4890000
5470000
3390000
98000
3260000
2990000
8400000
1620000
7050000
1640000
950000
2695000
2160000
2232000
2234500
6930000
6930000
1703000
3990000
4240000

0.00000

0.00372

0.00066

0.00000

0.00000

0.00035

0.00000

0.00107

0.00000

0.00000

0.00000

0.00000

0.00000

0.00000

0.00000

0.00000

0.00226

0.00226

0.00000

0.00000

0.00000

0.00000

0.00000

0.00016

0.00000

0.00000

0.00000

0.00260

0.0000

.

0.00000
0.00027

0.00000

0.00000

0.00167

0.00000

0.00000

0.00000

0.00000

0.00000

0.00000

0.00000

0.00000

0
2
1
0
0
0
0
0
1
0
0
0
0
0
0
0
0
0
0
0
2
0
0
0
0
0
0
0
0
0
0
0
0
2
0
0
0
0
0
2
0
0
0
0
0
0
0
0
0




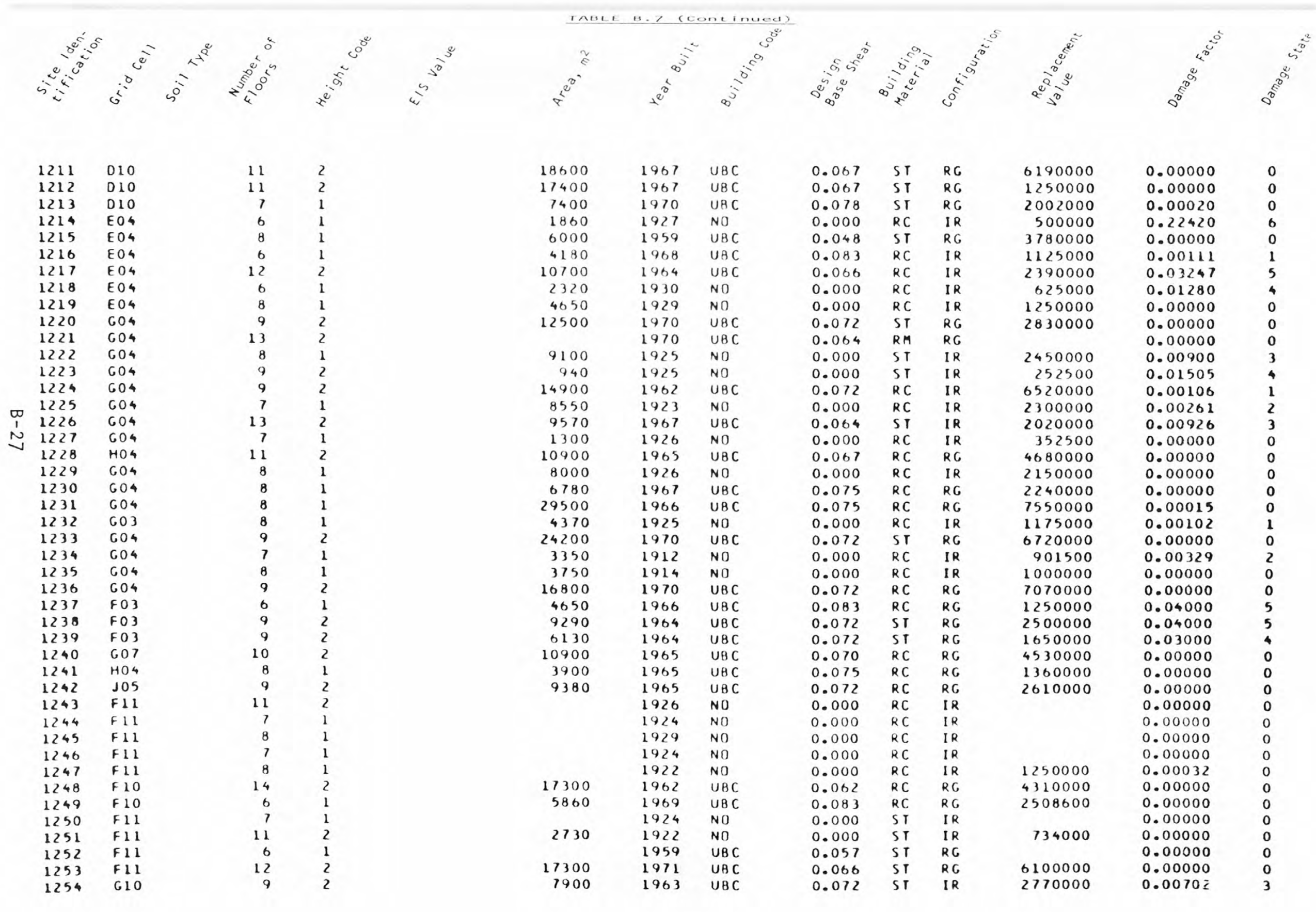




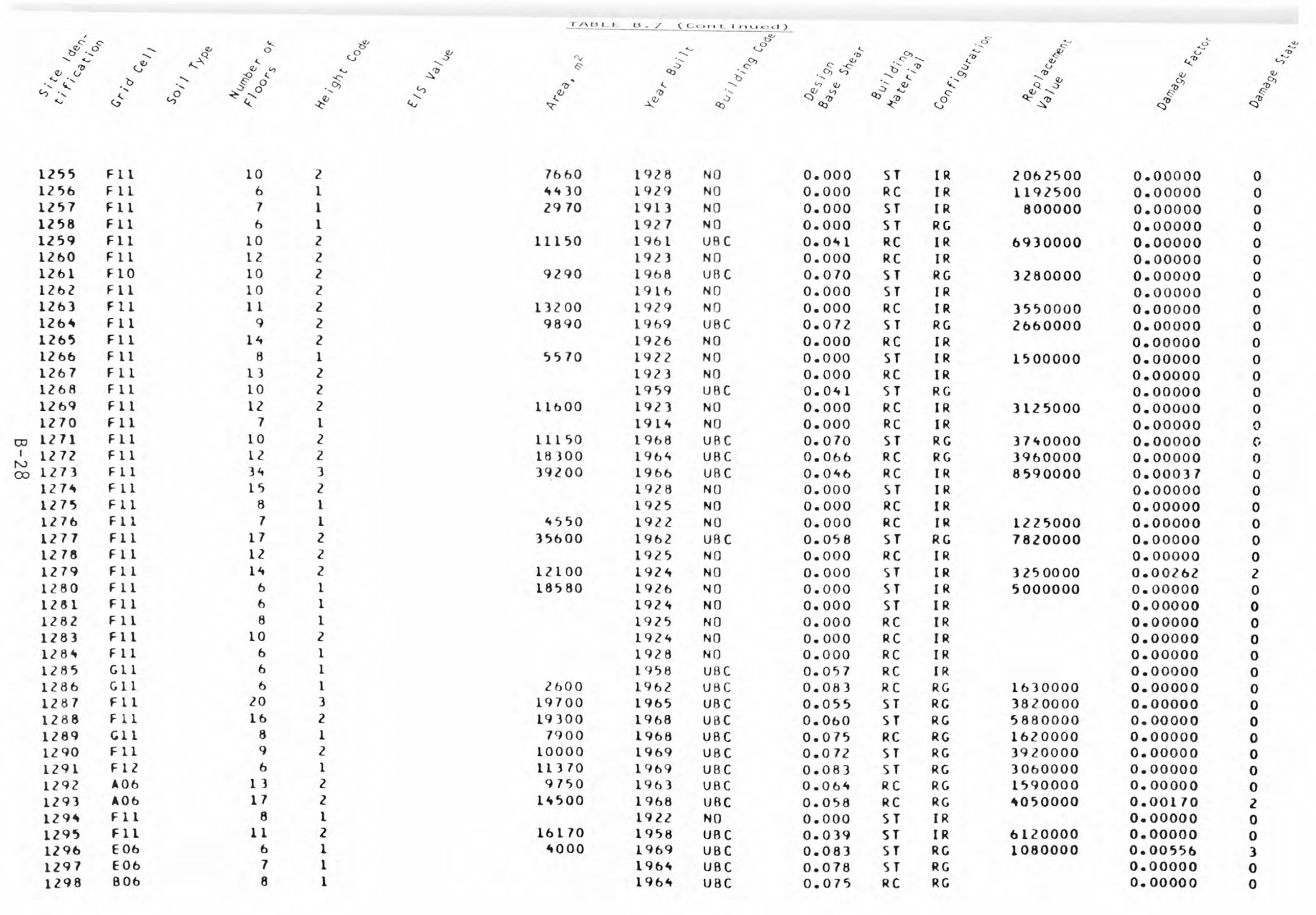



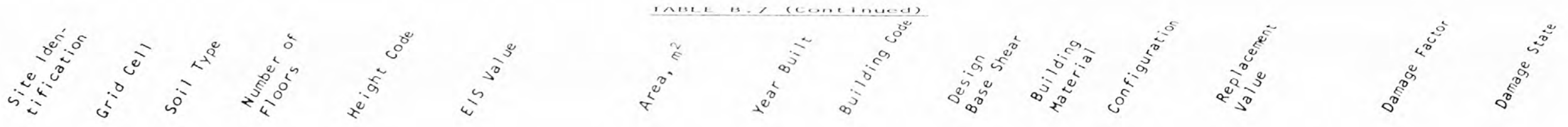

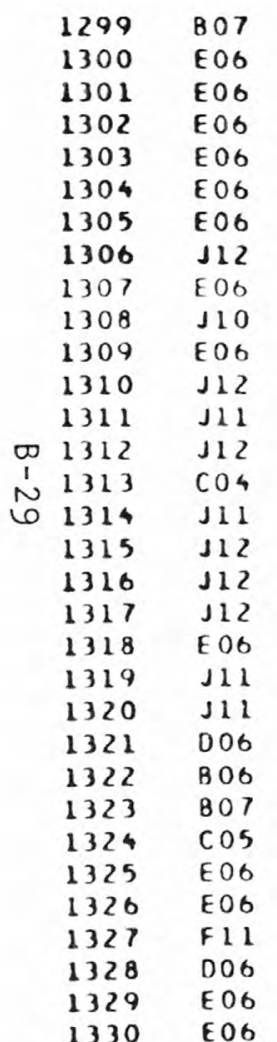

$\begin{array}{rll}5340 & 1968 & \text { UBC } \\ 6180 & 1923 & \text { NO } \\ 8180 & 1924 & N O \\ 3860 & 1928 & N O \\ 16440 & 1921 & \text { NO } \\ 16200 & 1906 & \text { NO } \\ & 1970 & \text { UBC } \\ 8900 & 1934 & \text { UBC } \\ 12100 & 1970 & \text { UBC } \\ & 1910 & \text { NO } \\ 4090 & 1960 & \text { UBC } \\ 11060 & 1970 & \text { UBC } \\ 13010 & 1968 & \text { UBC } \\ 13900 & 1962 & \text { UBC } \\ 10000 & 1968 & \text { UBC } \\ 49800 & 1960 & \text { UBC } \\ 9290 & 1964 & \text { UBC } \\ 11150 & 1970 & \text { UBC } \\ & 1924 & \text { NO } \\ 11150 & 1963 & \text { UBC } \\ 11150 & 1967 & \text { UBC } \\ 6970 & 1929 & \text { NO } \\ 42100 & 1957 & \text { UBC } \\ 34700 & 1970 & \text { UBC } \\ 1860 & 1959 & \text { UBC } \\ 7430 & 1913 & \text { NO } \\ 37900 & 1928 & \text { NO } \\ 21400 & 1916 & \text { NO } \\ 7250 & 1930 & \text { NO } \\ 16160 & 1916 & \text { NO } \\ 5750 & 1948 & \text { UBC }\end{array}$

$\begin{array}{lll}0.075 & R C & R G \\ 0.000 & S T & I R \\ 0.000 & S T & I R \\ 0.000 & S T & I R \\ 0.000 & S T & I R \\ 0.000 & S T & I R \\ 0.000 & R C & I R \\ 0.072 & R C & R G \\ 0.010 & S T & I R \\ 0.070 & S T & R G \\ 0.000 & S T & I R \\ 0.039 & S T & R G \\ 0.066 & S T & R G \\ 0.070 & R C & R G \\ 0.062 & S T & R G \\ 0.070 & R C & R G \\ 0.067 & R C & R G \\ 0.070 & S T & R G \\ 0.067 & S T & R G \\ 0.000 & R C & I R \\ 0.066 & S T & R G \\ 0.066 & S T & R C \\ 0.000 & R C & I R \\ 0.033 & R C & R G \\ 0.058 & R C & I R \\ 0.057 & S T & R G \\ 0.000 & R C & I R \\ 0.000 & S T & I R \\ 0.000 & S T & I R \\ 0.000 & R C & I R \\ 0.000 & S T & I R \\ 0.052 & R C & R G \\ & & \end{array}$

1437500

1662500

2200000

1037500

4425000

4375000

2400000

3010000

2064000

2040000

2800000

24900

4160000

3540000

7500

4920000

4340000

1875000

14140000

9680000

500000

2000000

10207000

5750000

1950000

4350000

0.00000 0.02087

0.01341

0.01045

0.01041

.01051

0.01047

0.01467

0.00000

0.00000

.00000

0.00000

0.00000

.00000

.00000

.00000

0.00000
0.00000

0.40000

0.00000

0.00000

0.01333

.00000

0.00000

0.00100

0.00400

0.01001

0.00000

0.00359

0.00287

0.00000 
TABLE B. 8

LOS AVGELES AREA GEID - SAN FEFNANOO EARTHQUAKE QIEEBTH

$30 / C+/ 01$

\begin{tabular}{|c|c|c|c|c|c|c|c|}
\hline \multirow{2}{*}{$\begin{array}{l}\text { GRIJ } \\
\text { CELL }\end{array}$} & \multirow[b]{2}{*}{-ATITUJE } & \multirow[b]{2}{*}{ LONGIIUDE } & \multirow{2}{*}{$\begin{array}{l}\text { SOIL } \\
\text { TYOE }\end{array}$} & \multicolumn{2}{|c|}{ EDICENTRAL } & \multirow[b]{2}{*}{$M M I$} & \multirow[b]{2}{*}{ DURATION } \\
\hline & & & & OISTANCE & $K M$ & & \\
\hline $\begin{array}{ll}401 \\
002\end{array}$ & 34.2980 & 118.5260 & $R K$ & & 17 & 8.0 & 36 \\
\hline $\begin{array}{ll}A 02 \\
A 03\end{array}$ & 34.2476 & 113.5260 & MA & & 21 & 8.0 & 42 \\
\hline $\begin{array}{lll}A O & 3 \\
A O & \end{array}$ & $\begin{array}{l}34.1968 \\
34.146 ?\end{array}$ & 113.5260 & OA & & $2 \epsilon$ & $7 \cdot 0$ & \\
\hline$A O 5$ & $\begin{array}{l}34.146 ? \\
3+.0956\end{array}$ & $\begin{array}{l}119.5260 \\
119.5260\end{array}$ & $\begin{array}{l}M A \\
R K\end{array}$ & & $\begin{array}{l}31 \\
3 t\end{array}$ & $\begin{array}{l}7.0 \\
5.0\end{array}$ & $\begin{array}{l}48 \\
49\end{array}$ \\
\hline$A 06$ & 34.0450 & $118.52 \in 0$ & LA & & 42 & 6.0 & 50 \\
\hline$A 07$ & 33.9944 & 119.5260 & MA & & 47 & 6.0 & 55 \\
\hline 801 & $34.29 B C$ & 118.4574 & MA & & 13 & 8.0 & 41 \\
\hline 302 & 34.2476 & 118.4574 & DA & & 19 & B. 0 & 47 \\
\hline $\begin{array}{l}303 \\
304\end{array}$ & $\begin{array}{l}34.1969 \\
34.1462\end{array}$ & $\begin{array}{l}113.4574 \\
118.4574\end{array}$ & $\begin{array}{l}\text { DA } \\
\text { JA }\end{array}$ & & $\begin{array}{ll}24 \\
29\end{array}$ & 3.0 & $\begin{array}{l}47 \\
53\end{array}$ \\
\hline 805 & 34.0956 & 118.4574 & RK & & 35 & 7.0 & $\begin{array}{l}53 \\
44\end{array}$ \\
\hline $30 E$ & 34.0450 & 118.4574 & MA & & 41 & 5.0 & 55 \\
\hline 307 & 33.9946 & 113.4574 & MA & & $4 t$ & 5.0 & 55 \\
\hline 308 & 33.9436 & 118.4574 & MA & & 52 & 6.0 & 56 \\
\hline $\mathrm{CO} 1$ & 34.2930 & 118.3883 & LA & & 12 & 3.0 & 36 \\
\hline 002 & 34.247. & 113.3883 & LA & & 18 & 8.0 & \\
\hline 003 & 34.1968 & 113.3853 & 04 & & 23 & 8.0 & 47 \\
\hline $\mathrm{CO}_{-}$ & 34.1462 & 113.3883 & DA & & 29 & 7.0 & 53 \\
\hline 005 & $3+.0955$ & 113.3883 & LA & & 35 & $7 \cdot 0$ & 44 \\
\hline $\cot$ & 34.0450 & $113.38 \varepsilon 8$ & MA & & 40 & 7.0 & 49 \\
\hline 607 & $\begin{array}{l}33.9945 \\
33.9438\end{array}$ & $\begin{array}{l}113.3993 \\
113.3883\end{array}$ & $\begin{array}{l}\text { MA } \\
\text { DA }\end{array}$ & & $\begin{array}{l}4 t \\
51\end{array}$ & $\begin{array}{l}6.0 \\
5.0\end{array}$ & $\begin{array}{l}55 \\
61\end{array}$ \\
\hline $\operatorname{cog}$ & 33.8932 & 119.3883 & $D A$ & & 57 & 6.0 & 61 \\
\hline C10 & $33.842 E$ & 118.3883 & DA & & 53 & 5.0 & 62 \\
\hline C 11 & $33.732 c$ & 119.3899 & $R K$ & & 68 & 6.0 & 52 \\
\hline$C 12$ & 33.7414 & 119.3888 & FK & & 74 & 6.0 & 53 \\
\hline 001 & 34.2990 & 113.3202 & $R<$ & & 14 & 8.0 & 36 \\
\hline 002 & 34.2476 & 113.3202 & LA & & 19 & 3.0 & 37 \\
\hline 303 & 34.1968 & 113.3202 & MA & & 24 & 8.0 & 42 \\
\hline 004 & 34.1462 & 119.3202 & MA & & $3 c$ & 7.0 & 48 \\
\hline 305 & 34.0955 & $119.320 ?$ & LA & & 35 & 7.0 & 44 \\
\hline 306 & 34.0450 & 113.3202 & MA & & 41 & 7.0 & 49 \\
\hline 007 & 33.9345 & 119.3202 & DA & & 46 & 7.0 & 55 \\
\hline 009 & 33.9438 & 113.3202 & DA & & 52 & 5.0 & 61 \\
\hline 303 & 33.8932 & $11 \% .3202$ & 04 & & $5 \varepsilon$ & 6.0 & 51 \\
\hline 016 & 33.8426 & 119.3202 & DA & & 63 & 5.0 & 62 \\
\hline D11 & 33.7920 & 118.3202 & LA & & 69 & 6.0 & 53 \\
\hline 012 & 33.7416 & 119.3202 & $R x$ & & 74 & 6.0 & 53 \\
\hline 01 & 34.2990 & 118.2516 & $R K$ & & 18 & 7.0 & 42 \\
\hline EO2 & 34.2474 & 116.2516 & LA & & 22 & 7.0 & 42 \\
\hline E03 & 34.1968 & 119.2516 & LA & & 27 & 7.0 & 43 \\
\hline $\mathrm{EO}_{4}$ & 34.1462 & 113.2516 & NA & & 36 & 7.0 & 48 \\
\hline EO5 & 34.0956 & 113.2516 & LA & & 37 & 7.0 & 44 \\
\hline$E O E$ & 34.0450 & 118.2516 & MA & & 42 & 7.0 & 49 \\
\hline 507 & 33.9944 & 118.2516 & DA & & 48 & 7.0 & 55 \\
\hline$\equiv 08$ & 33.9433 & 113.2516 & $O A$ & & 53 & 6.0 & 61 \\
\hline 509 & 33.8932 & 119.2516 & $O A$ & & 59 & 6.0 & 62 \\
\hline E 10 & 33.8426 & 118.2516 & $D A$ & & 64 & 6.0 & 62 \\
\hline E11 & 33.7920 & 118.2516 & OS & & 70 & 6.0 & 63 \\
\hline E 12 & 33.7414 & 119.2516 & 05 & & 75 & 5.0 & 63 \\
\hline Fo1 & 34.2930 & 118.1830 & RK & & 23 & 7.0 & 43 \\
\hline FO2 & 34.2474 & 119.1830 & $R K$ & & 27 & 7.0 & 43 \\
\hline Fo3 & 34.1963 & 118.1830 & MA & & 31 & 7.0 & 48 \\
\hline $\mathrm{FOH}_{4}$ & 34.1462 & 113.1830 & LA & & 35 & 7.0 & 44 \\
\hline FO5 & $34.095 E$ & 113.1830 & MA & & 40 & 7.0 & 49 \\
\hline FOE & 34.0450 & 113.1830 & MA & & 45 & 7.0 & \\
\hline F 07 & $33.994-$ & 113.1830 & DA & & 50 & 7.0 & \\
\hline $\mathrm{FOB}$ & 33.9439 & 119.1330 & $D A$ & & 55 & 6.0 & 61 \\
\hline F09 & 33.8332 & 113.1830 & $O A$ & & 60 & 6.0 & 62 \\
\hline$F 10$ & 33.8426 & 113.1830 & $O \Delta$ & & $6 t$ & 5.0 & 62 \\
\hline F 11 & 33.7920 & 119.1830 & OS & & 71 & 5.0 & 63 \\
\hline
\end{tabular}


TABLE B.8 (Continued)

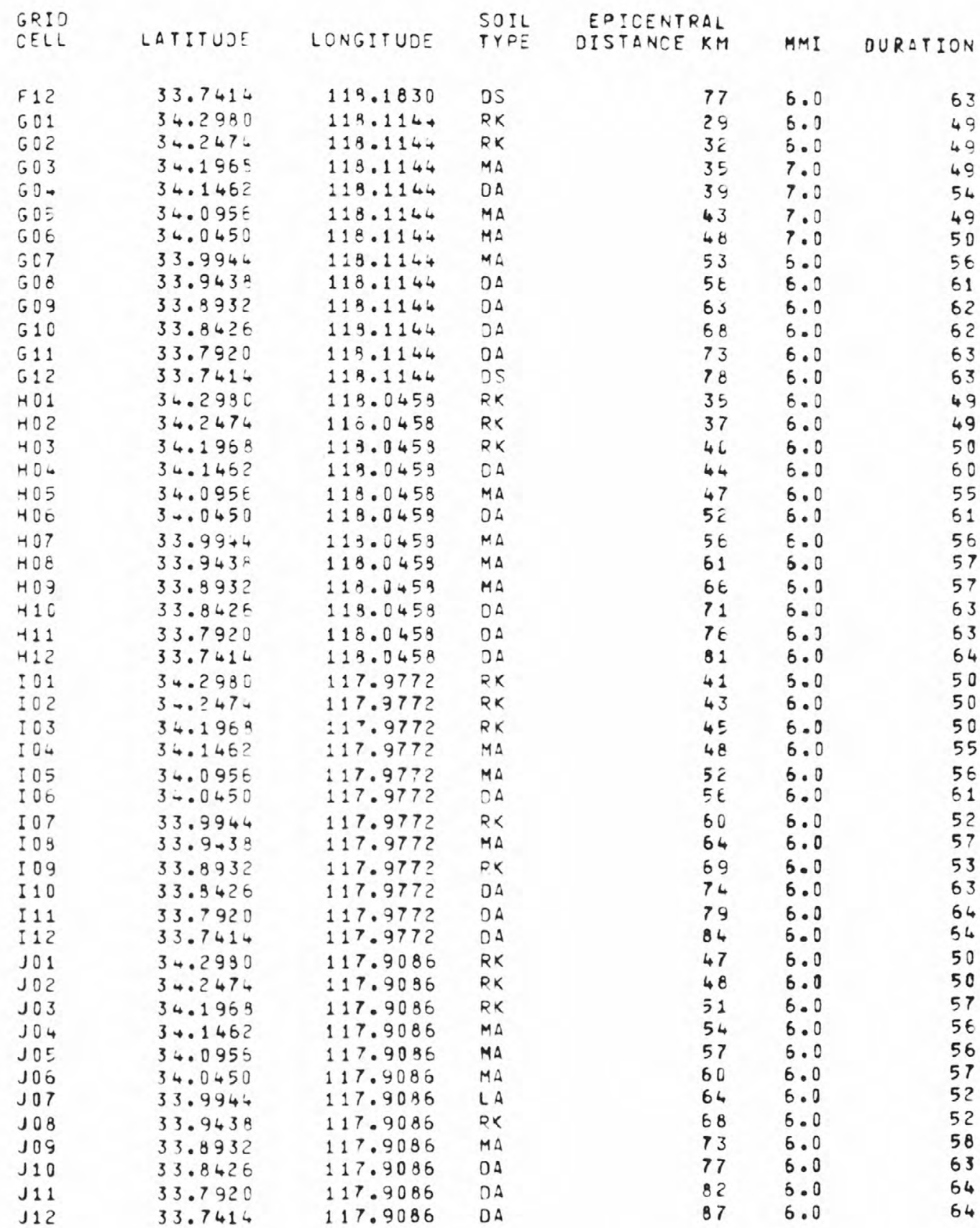


TABLE B.9

NUMBER OF BUILDINGS IN EACH CELL

OF LOS ANGELES AREA GRID

$--$

TALLY/EACH/C 38

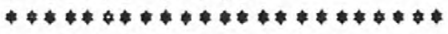

ELEMENT- SITE LOCATION COOE /A2Z/H83/

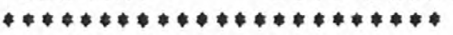

FREOUENCY VALUE

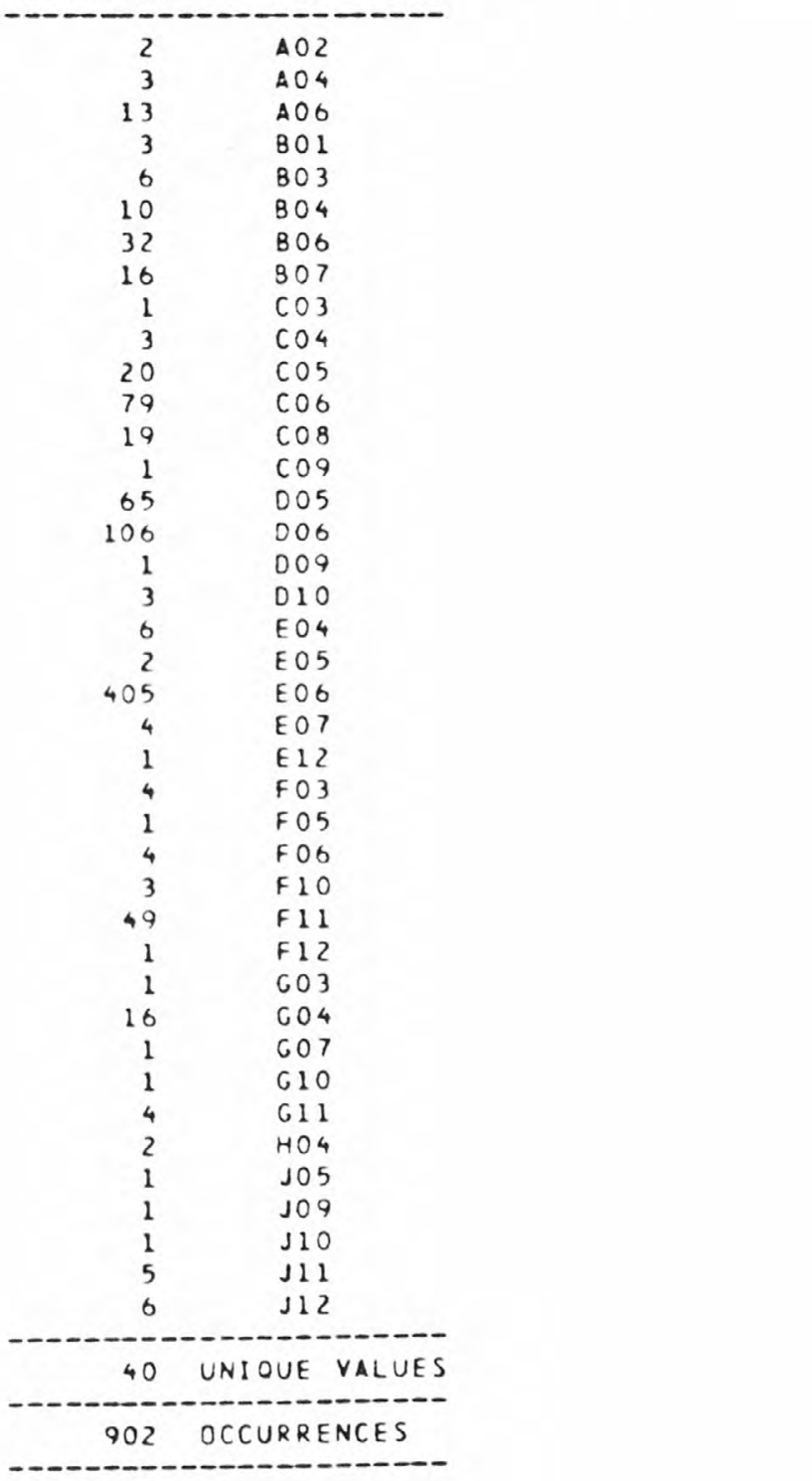


TABLE B. 10

$\frac{\text { UNOAMAGED CONCRETE BUILOINGS IN GRID CELL DOS }}{80 / 04 / 07}$

\begin{tabular}{|c|c|c|c|c|c|c|c|c|c|}
\hline SITE & NO. OF & HEIGHT & $\triangle R E A$ & YEAR & $B L D G$ & BASE & $B L D G$ & & DAMAGE \\
\hline 10 & FLOORS & CODE & SO.M & BUILT & CODE & SHEAR & MATL & CONFIC & STATE \\
\hline 956 & 6 & 1 & & 1929 & NO & 0.000 & $R C$ & $I R$ & 0 \\
\hline 955 & 6 & 1 & & 1929 & NO & 0.000 & $R C$ & I R & 0 \\
\hline 957 & 6 & 1 & & 1928 & NO & 0.000 & $R C$ & I R & 0 \\
\hline 782 & 6 & 1 & & 1926 & NO & 0.000 & $R C$ & IR & 0 \\
\hline 1022 & 6 & 1 & & 1927 & NO & 0.000 & $R C$ & IR & 0 \\
\hline 928 & 6 & 1 & & 1929 & NO & 0.000 & $R C$ & $I R$ & 0 \\
\hline 1074 & 6 & 1 & & 1920 & NO & 0.000 & $R C$ & I $R$ & 0 \\
\hline 658 & 6 & 1 & & 1929 & NO & 0.000 & $R C$ & I R & 0 \\
\hline 656 & 6 & 1 & & 1920 & NO & 0.000 & $R C$ & I $R$ & 0 \\
\hline 550 & 6 & 1 & & 1930 & NO & 0.000 & $R C$ & IR & 0 \\
\hline 538 & 6 & 1 & & 1927 & NO & 0.000 & $R C$ & $R G$ & 0 \\
\hline 958 & 7 & 1 & & 1929 & NO & 0.000 & $R C$ & I R & 0 \\
\hline 959 & 7 & 1 & & 1930 & ND & 0.000 & $R C$ & I R & 0 \\
\hline 1026 & 7 & 1 & & 1915 & NO & 0.000 & $R C$ & IR & 0 \\
\hline 903 & 7 & 1 & & 1928 & NO & 0.000 & $R C$ & IR & 0 \\
\hline 179 & 7 & 1 & & 1929 & NO & 0.000 & $R C$ & I R & 0 \\
\hline 730 & 7 & 1 & & 1929 & NO & 0.000 & $R C$ & IR & 0 \\
\hline 1035 & 7 & 1 & & 1926 & NO & 0.000 & $R C$ & I R & 0 \\
\hline 781 & 8 & 1 & & 1923 & NO & 0.000 & $R C$ & IR & 0 \\
\hline 180 & 8 & 1 & & 1931 & NO & 0.000 & $R C$ & I $R$ & 0 \\
\hline 934 & 8 & 1 & & 1928 & NO & 0.000 & $R C$ & I R & 0 \\
\hline 933 & 8 & 1 & & 1915 & NO & 0.000 & $R C$ & I R & 0 \\
\hline 1069 & 10 & 2 & & 1924 & NO & 0.000 & $R C$ & IR & 0 \\
\hline 1097 & 12 & 2 & & 1929 & NO & 0.000 & $R C$ & $R G$ & 0 \\
\hline 1063 & 13 & 2 & & 1928 & NO & 0.000 & $R C$ & I $R$ & 0 \\
\hline 1094 & 13 & 2 & & 1930 & NO & 0.000 & $R C$ & $R G$ & 0 \\
\hline 1073 & 13 & 2 & & 1924 & NO & 0.000 & $R C$ & I $R$ & 0 \\
\hline 720 & 13 & 2 & 15700 & 1950 & UBC & 0.034 & $R C$ & I R & 0 \\
\hline 721 & 13 & 2 & 15700 & 1950 & $\cup B C$ & 0.034 & $R C$ & IR & 0 \\
\hline 122 & 13 & 2 & 15700 & 1950 & $\cup B C$ & 0.034 & $R C$ & I R & 0 \\
\hline 123 & 13 & 2 & 15700 & 1950 & UBC & 0.034 & $R C$ & I R & 0 \\
\hline 724 & 13 & 2 & 15700 & 1950 & UBC & 0.034 & $R C$ & I R & 0 \\
\hline 125 & 13 & 2 & 15700 & 1950 & $\cup B C$ & 0.034 & $R C$ & IR & 0 \\
\hline 126 & 13 & 2 & 15700 & 1950 & $\cup B C$ & 0.034 & $R C$ & I R & 0 \\
\hline 175 & 13 & 2 & 15700 & 1950 & UBC & 0.034 & $R C$ & I R & 0 \\
\hline 176 & 13 & 2 & 15700 & 1950 & UBC & 0.034 & $R C$ & $I R$ & 0 \\
\hline 177 & 13 & 2 & 15700 & 1950 & UBC & 0.034 & $R C$ & I R & 0 \\
\hline 1071 & 13 & 2 & 18700 & 1955 & UBC & 0.034 & $R C$ & $R G$ & 0 \\
\hline 797 & 13 & 2 & 15700 & 1950 & UBC & 0.034 & $R C$ & I $R$ & 0 \\
\hline 798 & 13 & 2 & 15700 & 1950 & $U B C$ & 0.034 & $R C$ & I R & 0 \\
\hline 799 & 13 & 2 & 15700 & 1950 & UBC & 0.034 & $R C$ & I $R$ & 0 \\
\hline 727 & 13 & 2 & 15700 & 1950 & UBC & 0.034 & $R C$ & I $R$ & 0 \\
\hline 1067 & 6 & 1 & & 1956 & UBC & 0.057 & $R C$ & I R & 0 \\
\hline 1039 & 6 & 1 & & 1960 & UBC & 0.057 & $R C$ & $R G$ & 0 \\
\hline 1079 & 12 & 2 & & 1965 & UBC & 0.066 & $R C$ & I R & 0 \\
\hline 1023 & 12 & 2 & 12100 & 1965 & UBC & 0.066 & $R C$ & I R & 0 \\
\hline 1083 & 11 & 2 & 37500 & 1969 & $\cup B C$ & 0.067 & $R C$ & $R G$ & 0 \\
\hline 899 & 8 & 1 & & 1963 & $U B C$ & 0.075 & $R C$ & I R & 0 \\
\hline 652 & 6 & 1 & & 1962 & $\cup B C$ & 0.083 & RC & $R G$ & 0 \\
\hline
\end{tabular}


PRINT C1,C2,C35 WHERE C1 EQ LOS ANGELES ANO C36EQ 220; CITY* LOS ANGELES

COUNTRY* UNITED STATES

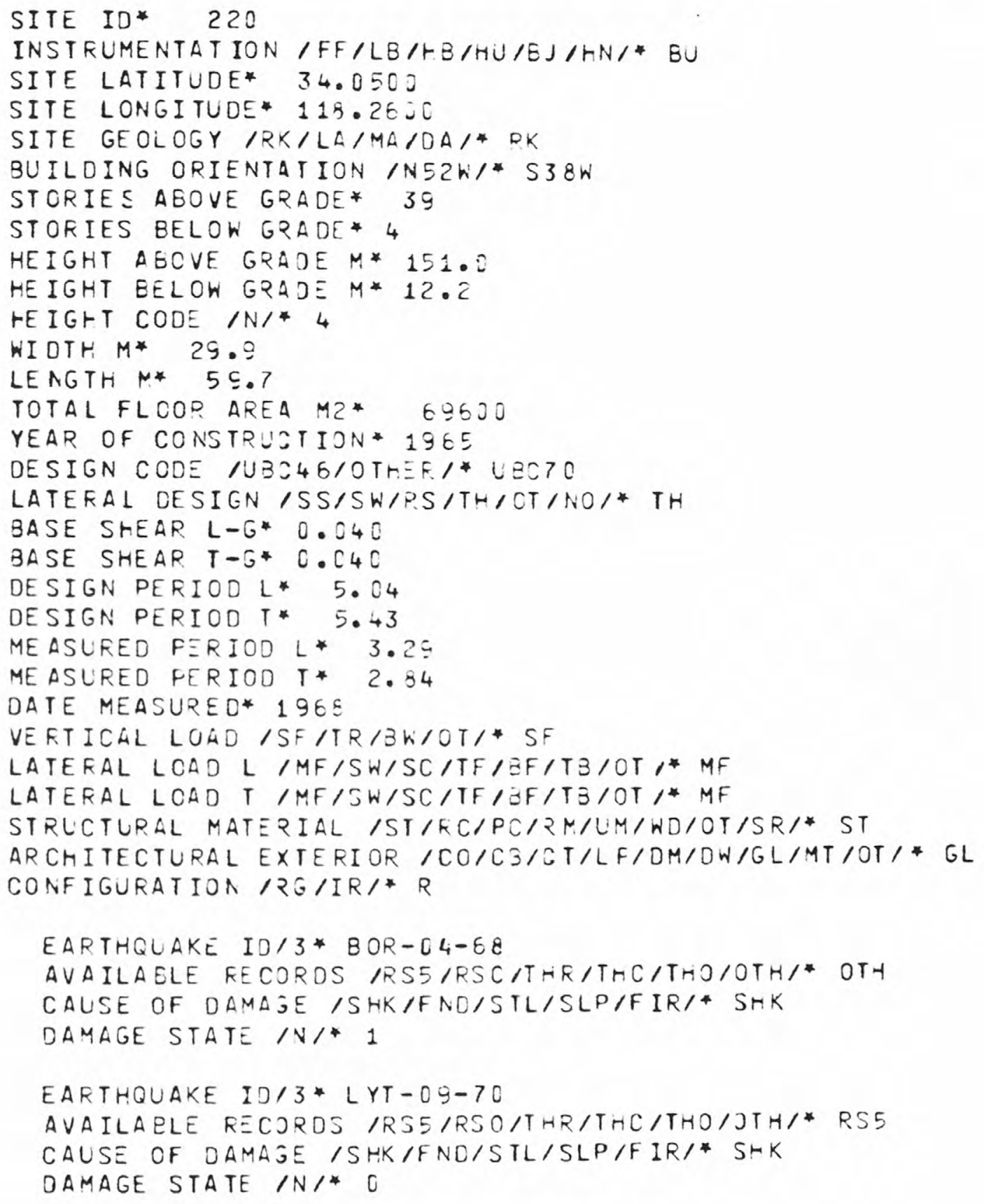

FIGURE B.1 SAMPLE LISTING FOR A BUILDING IN LOS ANGELES, CALIFORNIA 


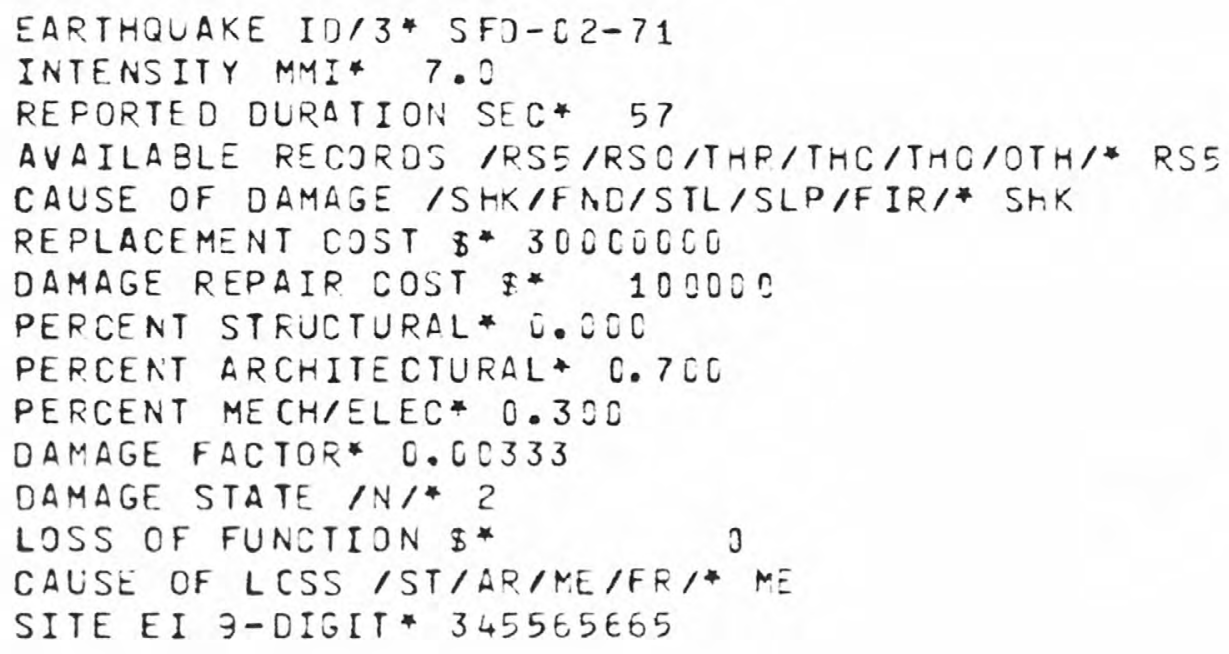

FIGURE B.1 (Continued) 
PRINT/NAME/C1, C2, 335 WHERE C1 EQ MEXICO ANO C36 EQ 501; CITY* MEXICO

COUNTRY* MEXICC

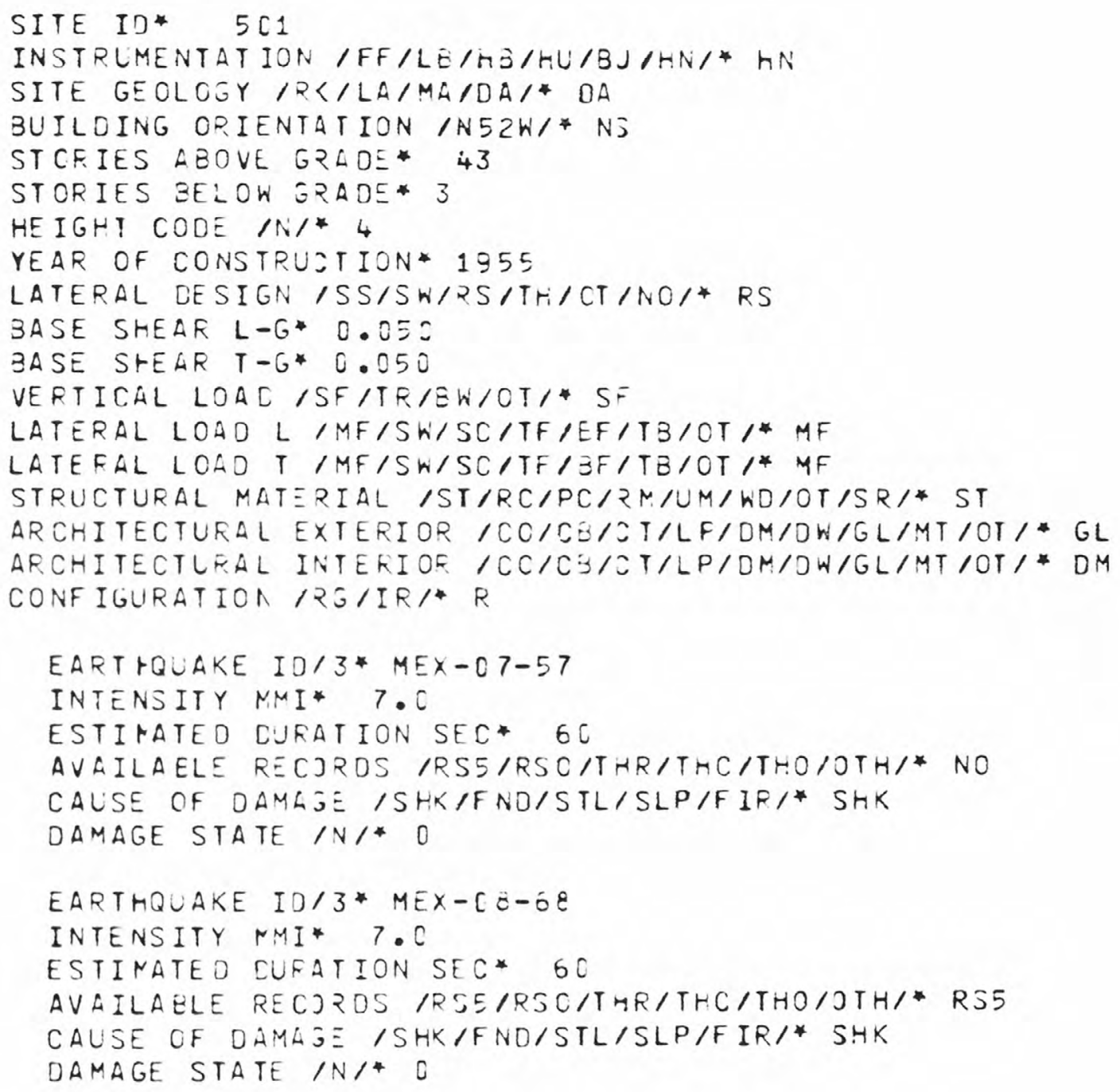

FIGURE B.2 SAMPLE LISTING FOR A BUILDING IN MEXICO CITY 


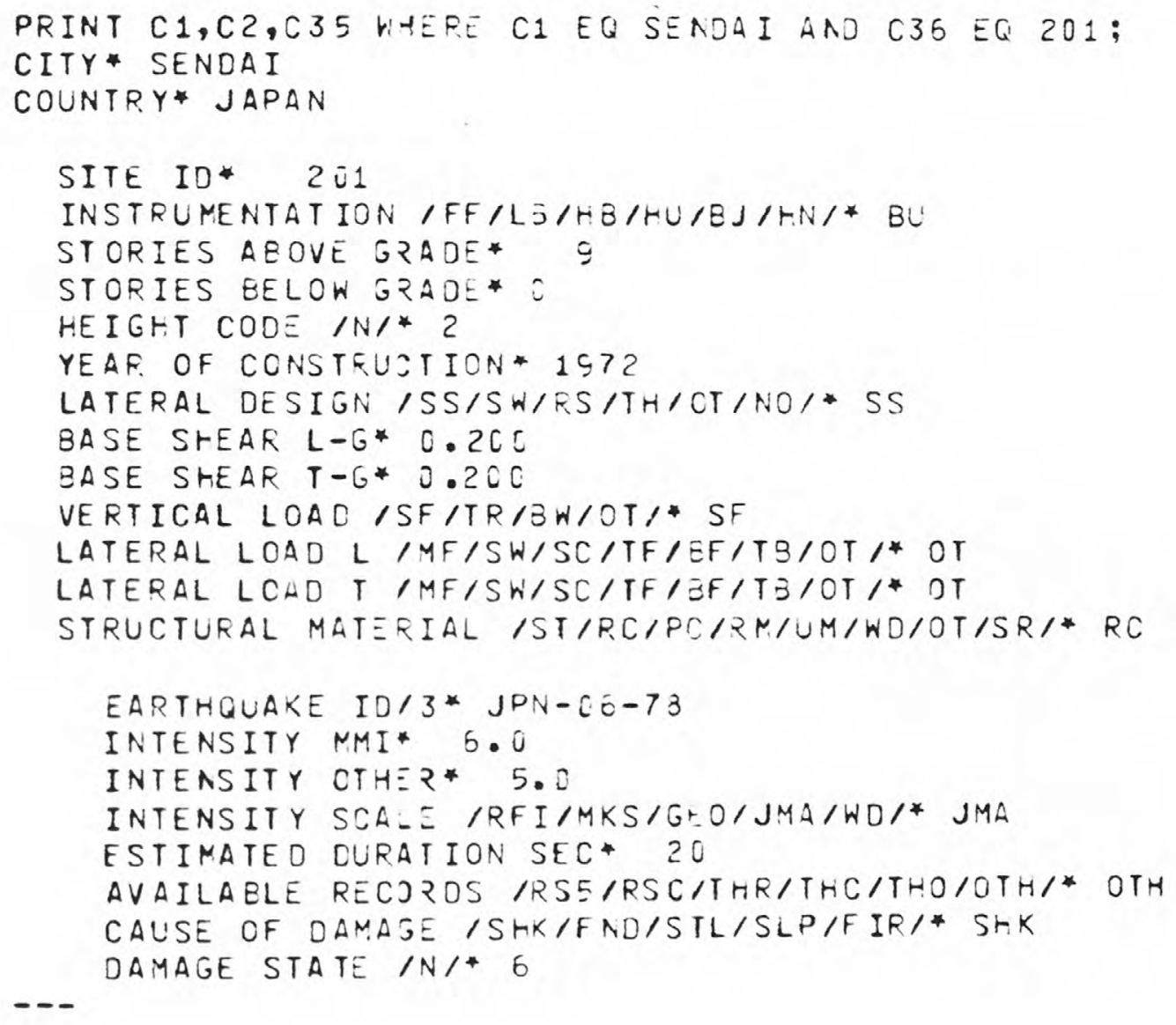

FIGURE B.3 SAMPLE LISTING FOR A BUILDING IN SENDAI, JAPAN 


\section{- epicenter, san fernando earthquake \\ $34.412^{\circ} \mathrm{N}, 118.4^{\circ} \mathrm{W}$}

$118.56^{\circ}$

$117.87^{\circ}$

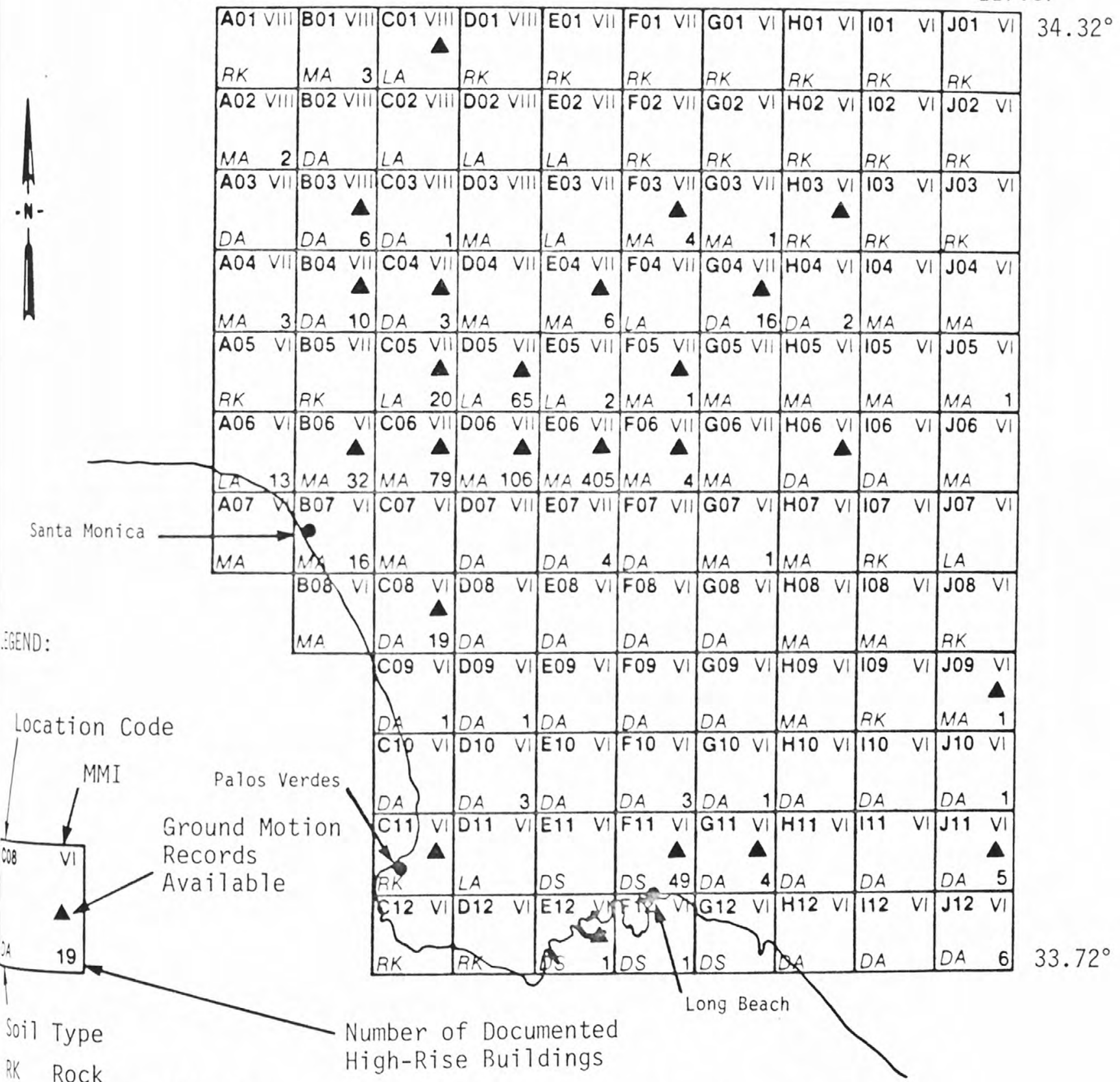

LA Shallow Alluvium

MA Medium Alluvium

DA Deep Alluvium

os Deep, Soft Alluvium

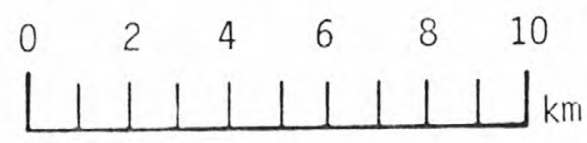

FIGURE B.4 LOS ANGELES AREA GRID AND DATA SUMMARY FOR THE

SAN FERNANDO EARTHQUAKE 


\section{APPENDIX C}

Seismological Intensity Scales 



\section{SEISMOLOGICAL INTENSITY SCALES}

Various seismological intensity scales have been developed in the past 200 years. Derived purely from empirical observations of damage, they provided the first scale form for communicating the destructive effects of earthquakes.

Because of the purely empirical manner in which the various seismological intensity scales were developed, they have thus far been of only limited value in calculating the response of structures to estimate the effects of a postulated earthquake. Various correlation studies (Gutenberg and Richter, 1942 and 1956; Hershberger, 1956; Ambraseys, 1974; Trifunac and Brady, 1975; and Gupta, 1980) have been conducted to relate seismological intensities with engineering ground-motion parameters (e.g., acceleration, velocity, and displacement), but these have serious limitations and thus far are accepted as only crude estimates. These limitations include wide scatter in the data (Ambraseys, 1974; Trifunac and Brady, 1975) and the inadequacy of a single ground-motion parameter such as peak acceleration for making estimates of nonlinear structure response (Scholl, 1974).

Until an engineering intensity scale is adequately enough developed to render it useful for making estimates of damage on the basis of response analysis, the seismological intensity scales will continue to be of value. In developing a useful engineering intensity scale, the various seismological intensity scales will be useful as a basis for establishing damage scenarios for the engineering intensity scale and for cross correlating various engineering ground motion parameters with seismological intensity values. Currently, damage scenarios are associated with various seismological intensity scales, but the seismological intensity ratings are of questionable value to the engineer for analysis. Similarly, an engineering intensity scale has been defined (Appendix D), but no damage scenarios have been defined for it. The two systems must be integrated. Some work has been done to correlate various seismological intensity scales (Barosh, 1969; Medvedev and Sponheuer, 1964); no work has been done to establish damage scenarios for an engineering intensity scale. 
of the seismological intensity scales in use throughout the world, five are of particular value for developing damage scenarios for an engineering intensity scale. These are:

- Modified Mercalli Scale (MM)

- Japan Meterological Agency Scale (JMA)

- Medvedev-Sponheuer-Karnik Scale (MSK)

- Rossi-Forel Scale (RF)

- geofian scale

Figure C.1 gives a graphic correlation showing the relationship between the five scales. These relationships were derived from information presented by Barosh (1969) and Richter (1958). Tables C.1 through C.5 are listings of the scales. 
I. Not felt-or, except rarely under especially favorable circumstances. Under certain conditions, at and outside the boundary of the area in which a great shock is felt:

sometimes birds, animals, reported uneasy or disturbed;

sometimes dizziness or nausea experienced;

sometimes trees, structures, liquids, bodies of water, may sway-doors may swing, very slowly.

II. Felt indoors by few, especially on upper floors, or by sensitive or nervous persons.

Also, as in grade I, but of ten more noticeably:

sometimes hanging objects may swing, especially when delicately suspended;

sometimes trees, structures, liquids, bodies of water, may sway, doors may swing, very slowly;

sometimes birds, snimals, reported uneasy or disturbed;

sometimes dizziness or nausea experienced.

III. Felt indoors by several, motion usually rapid vibration.

Sometimes not recognized to be an earthquake at first.

Duration estimated in some cases.

Vibration like that due to passing of light, or lightly loaded trucks, or heavy trucks some distance away.

Hanging objects may swing slightly.

Movements may be appreciable on upper levels of tall structures.

Rocked standing motor cars slightly.

IV. Felt indoors by many, outdoors by few.

Awakened few, expecially light sleepers.

Frightened no one, unless apprehensive from previous experience.

Vibration like that due to passing of heavy, or heavily loaded trucks.

Sensation like heavy body striking building, or falling of heavy objects inside.

Rattling of dishes, windows, doors; glassware and crockery clink and clash.

Creaking of walls, frame, especially in the upper range of this grade.

Hanging objects swung, in numerous instances.

Disturbed liquids in open vessels slightly.

Rocked standing motor cars noticeably.

V. Felt indoors by practically all, outdoors by many or most: outdoors direction estimated.

Awakened many, or most.

Frightened few-slight excitement, a few ran outdoors.

Buildings trembled throughout.

Broke dishes, glassware, to some extent.

Cracked windows - in some cases, but not generally.

Overturned vases, small or unstable objects, in many instances, with occasional fall.

Hanging objects, doors, swing generally or considerably.

Knocked pictures against walls, or swung them out of place.

Opened, or closed, doors, shutters, abruptly.

Pendulum clocks stopped, started, or ran fast, or slow.

Moved small objects, furnishings, the latter to slight extent.

Spilled liquids in small amounts from well-filled open containers.

Trees, bushes, shaken slightly.

\footnotetext{
*Adapted from Sieberg's (1929) Mercalli-Cancani scale, modified and condensed. Quoted from Wood and Neumann (1931).
} 
VI. Felt by all, indoors and outdoors.

Frightened many, excitement general, some alarm, many ran outdoors.

Awakened all.

Persons made to move unsteadily.

Trees, bushes, shaken slightly to moderately.

Liquid set in strong motion.

Small bells rang - church, chapel, school, etc.

Damage slight in poorly built buildings.

Fall of plaster in small amount.

Cracked plaster somewhat, especially fine cracks chimneys in some instances.

Broke dishes, glassware, in considerable quantity, also some windows.

Fall of knick-knacks, books, pictures.

Overturned furniture in many instances.

Moved furnishings of moderately heavy kind.

VII. Frightened all-general alarm, all ran outdoors.

Some, or many, found it difficult to stand.

Noticed by persons driving motor cars.

Trees and bushes shaken moderately to strongly.

Waves on ponds, lakes, and running water.

Water turbid from mud stirred up.

Incaving to some extent of sand or gravel stream banks.

Rang large church bells, etc.

Suspended objects made to quiver.

Damage negligible in buildings of good design and construction, slight to moderate in well-built ordinary buildings, considerable in poorly built or badly designed buildings, adobe houses, old walls (especially where laid up without mortar), spires, etc.

Cracked chimneys to considerable extent, walls to some extent.

Fall of plaster in considerable to large amount, also some stucco.

Broke numerous windows, furniture to some extent.

Shook down loosened brickwork and tiles.

Broke weak chimneys at the roofline (sometimes damaging roofs).

Fall of cornices from towers and high buildings.

Dislodged bricks and stones.

Overturned heavy furniture, with damage from breaking.

D) amage considerable to concrete irrigation ditches.

VIII. Fright general-alarm approaches panic.

Disturbed persons driving motor cars.

Trees shaken strongly-branches, trunks, broken off, especially palm trees.

Ejected sand and mud in small amounts.

Changes: temporary, permanent; in flow of springs and wells; dry wells renewed flow; in temperature of spring and well waters.

Damage slight in structures (brick) built especially to withstand earthquakes.

Considerable in ordinary substantial buildings, partial collapse: racked, tumbled down, wooden houses in some cases; threw out panel walls in frame structures, broke off decayed piling.

Fall of walls.

Cracked, broke, solid stone walls seriously.

Wet ground to some extent, also ground on steep slopes.

Twisting, fall, of chimneys, columns, monuments, also factory stacks, towers.

Moved conspicuously, overturned, very heavy furniture. 
IX. Panic general.

Cracked ground conspicuously.

Damage considerable in (masonry) structures built especially to withstand earthquakes:

threw out of plumb some wood-frame houses built especially to withstand earthquakes;

great in substantial (masonry) buildings, some collapse in large part; or wholly shifted frame buildings off foundations, racked frames; serious to reservoirs; underground pipes sometimes broken.

$X$. Cracked ground, especially when loose and wet, up to widths of several inches; fissures up to a yard in width ran parallel to canal and stream banks.

Landslides considerable from river banks and steep coasts.

Shifted sand and mud horizontally on beaches and flat land.

Changed level of water in wells.

Threw water on banks of canals, lakes, rivers, etc.

Damage serious to dams, dikes, embankments.

Damage severe to well-built wooden structures and bridges, some destroyed.

Developed dangerous cracks in excellent brick walls.

Destroyed most masonry and frame structures, also their foundations.

Bent railroad rails slightly.

Tore apart, or (rushed endwise, pipe lines buried in earth.

Open cracks and broad wavy folds in cement pavements and asphalt road surfaces.

XI. Disturbances in ground many and widespread, varying with ground material.

Broad fissures, earth slumps, and land slips in soft, wet ground.

Ejected water in large amount charged with sand and mud.

Caused sea-waves (tidal waves) of significant magnitude.

Damage severe to wood-frame structures, especially near shock centers. Great to dams, dikes, embankments, often for long distances.

Few, if any (masonry), structures remained standing.

Destroyed large well-built bridges by the wrecking of supporting piers, or pillars.

Affected yielding wooden bridges less.

Bent railroad rails greatly, and thrust them endwise.

Put pipe lines buried in earth completely out of service.

XII. Damage total-practically all works of construction damaged greatly or destroyed.

Disturbances in ground great and varied, numerous shearing cracks.

Landslides, falls of rock of significant character, slumping of river banks, etc., numerous and extensive.

Wrenched loose, tore off, large rock masses.

Fault slips in firm rock, with notable horizontal and vertical offet displacements.

Water channels, surface and underground, disturbed and modified greatly.

Dammed lakes, produced waterfalls, deflected rivers, etc.

Waves seen on ground surfaces (actually seen, probably, in some cases).

Distorted lines of sight and level.

Threw objects upward into the air. 
(Abridged)

I. Not felt except by a very few under especially favorable circumstances.

II. Felt only by $\mathrm{a}$ few persons at rest, especially on upper floors of buildings. Delicately suspended objects may swing.

III. Felt quite noticeably indoors, especially on upper floors of buildings, but many people do not recognize it as an earthquake. Standing motor cars may rock slightly. Vibration like passing of truck. Duration estimated.

IV. During the day felt indoors by many, outdoors by few. At night some awakened. Dishes, windows, doors disturbed; walls made cracking sound. Sensation like heavy truck striking building. Standing motor cars rocked noticeably.

V. Felt by nearly everyone; many awakened. Some dishes, windows, etc., broken; a few instances of cracked plaster; unstable objects overturned. Disturbance of trees, poles and other tall objects sometimes noticed. Pendulum clocks may stop.

VI. Felt by all; many frightened and run outdoors. Some heavy furniture moved; a few instances of fallen plaster or damaged chimneys. Damage slight.

VII. Everybody runs outdoors. Damage negligible in buildings of good design and construction; slight to moderate in well-built ordinary structures; considerable in poorly built or badly designed structures; some chimneys broken. Noticed by persons driving motor cars.

VIII. Damage slight in specially designed structures; considerable in ordinary substantial buildings with partial collapse; great in poorly built struc. tures. Panel walls thrown out of frame structures. Fall of chimneys, factory stacks, columns, monuments, walls. Heavy furniture overturned. Sand and mud ejected in small amounts. Changes in well water. Disturbed persons driving motor cars.

IX. Damage considerable in specially designed structures; well designed frame structures thrown out of plumb; great in substantial buildings, with partial collapse. Buildings shifted off foundations. Ground cracked conspicuously. Underground pipes broken.

$X$. Some well-built wooden structures destroyed; most masonry and frame structures destroyed with foundations; ground badly cracked. Rails bent. Landslides considerable from river banks and steep slopes. Shifted sand and mud. Water splashed (slopped) over banks.

XI. Few, if any (masonry), structures remain standing. Bridges destroyed. Broad fissures in ground. Underground pipe lines completely out of service. Earth slumps and land slips in soft ground. Rails bent greatly.

XII. Damage total. Waves seen on ground surfaces. Lines of sight and level distorted. Objects thrown upward into the air. 
TABLE C.2

ROSSI-FOREL (RF) INTENSITY SCALE*

I. Microseismic shock. Recorded by a single seismograph or by seismographs of the same model, but not by several seismographs of different kinds: the shock felt by an experienced observer.

II. Extremely feeble shock. Recorded by several seismographs of different kinds; felt by a small number of persons at rest.

III. Very feeble shock. Felt by several persons at rest; strong enough for the direction or duration to be appreciable.

IV. Feeble shock. Felt by persons in motion; disturbance of movable objects, doors, windows, cracking of ceilings.

V. Shock of moderate intensity. Felt generally by everyone; disturbance of furniture, beds, etc., ringing of some bells.

VI. Fairly strong shock. General awakening of those asleep; general ringing of bells; oscillation of chandeliers; stopping of clocks; visible agitation of trees and shrubs; some startled persons leaving their dwellings.

VII. Strong shock. Overthrow of movable objects; fall of plaster; ringing of church bells; general panic, without damage to buildings.

VIII. Very strong shock. Fall of chimneys; cracks in the walls of buildings.

IX. Extremely strong shock. Partial or total destruction of some buildings.

X. Shock of extreme intensity. Great disaster; ruins; disturbance of the strata, fissures in the ground, rock falls from mountains.

*After Rossi (1883). Quoted from Richter (1958). 


\section{CLASSIFICATION OF THE SCALE}

1. Types of structures (buildings not antiseismic): Structure A: Buildings in field-stone, rural structures, adobe houses, clay
houses.

B: Ordinary brick buildings, buildings of the large block and prefabricated type, half timbered structures, buildings in natural hewn stone.

2. Definition of quantity:

C: Reinforced buildings, well-built wooden structures.

3. Classification of damage to buildings:

$$
\begin{aligned}
& \text { Single, few: about } 5 \text { percent } \\
& \text { Many: about } 50 \text { percent } \\
& \text { Most: about } 75 \text { percent }
\end{aligned}
$$

Grade 1-Slight damage: Fine cracks in plaster; fall of small pieces of plaster.

Grade 2-Moderate damage: Small cracks in walls; fall of fairly larger pieces of plaster; pantiles slip off; cracks in chimneys; parts of chimneys fall down.

Grade 3-Heavy damage: Large and deep cracks in walls; fall of chimneys.

Grade 4-Destruction:

Gaps in walls; parts of buildings may collapse; separate parts of the building lose their cohesion; inner walls and filled-in

Grade 5-Total walls of the frame collapse.

4. Arrangement of the Scale: Total collapse of buildings.

s. Persons and surroundings.

b. Structures of all kinds.

c. Nature.

I. Not noticeable:

\section{INTENSITY 8CALE}

a. The intensity of the vibration is below the limit of sensibility; the tremor is detected and recorded by seismographs only.

II. Scarcely noticeable (very slight):

a. Vibration is felt only by individual people at rest in houses, especially on upper floors of buildings.

III. Weak, partially observed only:

a. The earthquake is felt indoors by a few people, outdoors only in favourable circumstances. The vibration is like thet due to the passing of a light truck. Attentive observers notice a slight swinging of hanging objects, somewhat more heavily on upper floors.

IV. Largely observed:

a. The earthquake is felt indoors by many people, outdoors by few. Here and there people awaken, but no one is frightened. The vibration is like that due to the passing of a heavily loaded truck. Windows, doors and dishes rattle. Floors and walls creak. Furniture begins to shake. Hanging objects swing slightly. Liquids in open vessels are slightly disturbed. In standing motor cars the shock is noticeable.

V. Awakening:

a. The earthquake is felt indoors by all, outdoors by many. Many sleeping people awake. A few run outdoors. Animals become uneasy. Buildings tremble throughout. Hanging objects swing considerably. Pictures knock against walls or swing out of place. Occasionally pendulum clocks stop. Few unstable objects may be overturned or shifted. Open doors and windows are thrust open and slam back again. Liquids spill in small amounts from wellfilled open containers. The sensation of vibration is like that due to a heavy object falling inside the building.

b. Slight damages of grade 1 in buildings of type A are possible.

c. Sometimes change in flow of springs.

*After Medvedev, Sponheuer, and Karnik (1965). Quoted from Barosh (1969). 


\section{TABLE C.3 (Continued)}

VI. Frightening:

a. Felt by most indoors and outdoors. Many people in buildings are frightened and run outdoors. A few persons lose their balance. Domestic animals run out of their stalls. In few instances dishes and glassware may break, books fall down. Heavy furniture may possibly move and small steeple bells may ring.

b. Damage of grade 1 is sustained in single buildings of type $B$ and in many of type A. Damage in few buildings of type $A$ is of grade 2 .

c. In few cases cracks up to widths of $1 \mathrm{~cm}$ possible in wet ground; in mountains occasional landslips; changes in flow of springs and

VII. Damage to buildings: in level of well water are observed.

a. Most people are frightened and run outdoors. Many find it difficult to stand. The vibration is noticed by persons driving motor cars. Large bells ring.

b. In many buildings of type $\mathrm{C}$ damage of grade 1 is caused; in many buildings of type $\mathrm{B}$ damage is of grade 2. Many buildings of type A suffer damage of grade 3 , few of grade 4 . In single instances landslips of roadway on steep slopes; cracks in roads; seams of pipelines damaged; cracks in stone walls.

c. Waves are formed on water, and water is made turbid by mud stirred up. Water levels in wells change, and the flow of springs changes. In few cases dry springs have their flow restored and existing springs stop flowing. In isolated instances parts of sandy or gravelly banks slip off.

VIII. Destruction of buildings:

a. Fright and panic; also persons driving motor cars are disturbed. Here and there branches of trees break off. Even heavy furniture moves and partly overturns. Hanging lamps are in part damaged.

b. Many buildings of type C suffer damage of grade 2, few of grade 3 . Many buildings of type $B$ suffer damage of grade 3, and many buildings of type A suffer damage of grade 4 . Occasional breakage of pipe seams. Memorials and monuments move and twist. Tombstones overturn. Stone walls collapse.

c. Small landslips in hollows and on banked roads on steep slopes; cracks in ground up to widths of several centimeters. Water in lakes becomes turbid. New reservoirs come into existence. I)ry wells refill and existing wells become dry. In many cases change in flow and level of water.

IX. General damage to buildings:

a. General panic; considerable damage to furniture. Animals run to and fro in confusion and cry.

b. Many buildings of type C suffer damage of grade 3, a few of grade 4 . Many buildings of type $B$ show damage of grade 4 ; a few of grade 5. Many buildings of type A suffer damage of grade 5 . Monuments and columns fall. Considerable damage to reservoirs; underground pipes partly broken. In individual cases railway lines are bent and roadways damaged.

c. On flat land overflow of water, sand and mud is often observed. Ground cracks to widths of up to $10 \mathrm{~cm}$, on slopes and river banks more than $10 \mathrm{~cm}$. furthermore a large number of slight cracks in ground; falls of rock, many landslides and earthflows; large waves on water. Dry wells renew their flow and existing wells drv up. 
X. General destruction of buildings:

b. Many buildings of type C suffer damage of grade 4 , a few of grade 5 . Many buildings of type $B$ show damage of grade 5 ; most of type A have destruction category 5 ; critical damage to dams and dykes and severe damage to bridges. Railway lines are bent slightly. Underground pipes are broken or bent. Road paving and asphalt show waves.

c. In ground, cracks up to widths of several decimeters, sometimes up to 1 meter. Parallel to water courses occur broad fissures. Loose ground slides from steep slopes. From river banks and steep coasts considerable landslides are possible. In coastal areas displacement of sand and mud; change of water level in wells; water from canals, lakes, rivers, etc., thrown on land. New lakes occur.

XI. Catastrophe:

b. Severe damage even to well-built buildings, bridges, water dams, and railway lines; highways become useless; underground pipes destroyed.

c. Ground considerably distorted by broad cracks and fissures, as well as by movement in horizontal and vertical directions; numerous landslips and falls of rock.

The intensity of the earthquake requires to be investigated specially.

XII. Landscape charges:

b. Practically all structures above and below ground are greatly damaged or destroyed.

c. The surface of the ground is radically changed. Considerable ground cracks with extensive vertical and horizontal movements are observed. Falls of rock and slumping of river banks over wide areas; lakes are dammed; waterfalls appear, and rivers are deflected.

The intensity of the earthquake requires to be investigated specially. 
TABLE C. 4

JAPAN METEOROLOGICAL AGENCY (JMA) SCALE*

0 . Not felt: too weak to be felt by humans; registered only by seismographs.

I. Slight: felt only feebly by persons at rest or by those who are especially observant of earthquakes.

II. Weak: felt by most persons; slight shaking of windows and Japanese latticed sliding doors (Shōji).

III. Moderately strong: shaking of houses and buildings, heavy rattling of windows and Japanese latticed sliding doors, swinging of hanging objects, stopping of some pendulum clocks, and moving of liquids in vessels; some people are so frightened that they run out of doors.

IV. Strong: strong shaking of houses and buildings, overturning of unstable objects, and spilling of liquids out of vessels.

V. Very strong: cracking brick and plaster walls, overturning stone lanterns and gravestones, and similar objects, damaging chimneys and mud-andplaster warehouses, and causing landslides in steep mountains.

VI. Disastrous: causing destruction of 1-30 percent of Japanese worlen houses ; causing large landslides; fissures in flat ground and some in low fields, accompanied by mud and waterspouts.

VII. Ruinous: causing destruction of more than 30 percent of the houses; causing large landslides, fissures and faults.

$\therefore$ Quoted from Barosh (1969). 


\begin{tabular}{|c|c|c|}
\hline Intensity & $\begin{array}{c}X_{0} \\
(\mathrm{~mm})\end{array}$ & Brlef description of earthquake \\
\hline $\begin{array}{l}1 \\
2 \\
3\end{array}$ & & $\begin{array}{l}\text { Oscillations of the ground are detected with instruments. } \\
\text { In individual cases felt by very sensitive persons at rest. } \\
\text { Oscillations felt by few persons. }\end{array}$ \\
\hline $\begin{array}{l}4 \\
5\end{array}$ & $\begin{array}{r}<0.5 \\
0.5-1.0\end{array}$ & $\begin{array}{l}\text { Noted by many persons. Windows or doors may rattle. } \\
\text { Objects swing, floors squeak, glasses jai, outer plaster } \\
\text { crumbles. }\end{array}$ \\
\hline 6 & 1. $1-2.0$ & $\begin{array}{l}\text { Light damage to buildings: thin cracks in plaster, cracks } \\
\text { in tile furnaces, etc. }\end{array}$ \\
\hline 7 & 2. $1-4.0$ & $\begin{array}{l}\text { Considerable damage to buildings: thin cracks in plaster } \\
\text { and stripping of individual pieces, thin cracks in walls. }\end{array}$ \\
\hline 8 & 4. $1-8.0$ & $\begin{array}{l}\text { Destruction in buildings: large cracks in walls, falling of } \\
\text { cornices or chimneys. }\end{array}$ \\
\hline 9 & 8. $1-16.0$ & $\begin{array}{l}\text { Collapse in some buildings; destruction of walls, roofs, } \\
\text { floors. }\end{array}$ \\
\hline 10 & 16. $1-32.0$ & $\begin{array}{l}\text { Collapse of many buildings; fissures in ground about } 1 \\
\text { meter wide. }\end{array}$ \\
\hline $\begin{array}{l}11 \\
12\end{array}$ & $>32.0$ & $\begin{array}{l}\text { Numerous fissures on the surface of the earth, large land- } \\
\text { slides in mountains. } \\
\text { Large scale change in the relief. }\end{array}$ \\
\hline
\end{tabular}

\section{DESCRIPTION OF AFTEREFFECTS OF EARTHQUAKES}

The force of the earthquake at points where there are no seismometers is determined from the aftereffects of the earthquake, as described below for:

1. Buildings and structures.

2. Residual phenomena in ground and change in the state of the ground and surface water.

3. Other symptoms.

The degree of damage and destruction resulting from an earthquake in buildings constructed without the necessary earthquake countermeasures is established in accordance with the following subdivisions:

I. By groups of buildings.

Group A-Single story buildings with walls of unfinished stone, raw brick, adobe, etc.

Group B-Brick and stone houses.

Group $C$-Frame houses.

II. By degree of damage.

Light damage-Thin cracks in plaster and in tile furnaces, crumbling of outer plaster, etc.

Considerable damage-Cracks in plaster, falling of pieces of plaster, thin cracks in the walls, cracks in partitions, damage to chimneys, furnaces, etc.

Destruction-Large cracks in walls, splitting of masonry, destruction of individual parts of walls, falling of cornices and parapets, collapse of plaster, falling of chimneys, furnaces, etc.

Collapses-Destruction of walls, roofs, and floors of the entire building or of considerable parts of the building and large deformation of the walls.

III. By the number of buildings.

Majority.

Many.

Individual.

Intensity:

Buildings and atructuree

I. No damage.

II. No damage.

III. No damage.

IV. No damage.

*Quoted from Barosh (1969). 
v. Light squeaking of floors and partitions. Jarring of glasses. Crumbling of outer plaster. Movement of unclosed doors and windows. Slight damage in individual buildings.

VI. Light damage in many buildings. In individual buildings of Groups $\mathrm{A}$ and $\mathrm{B}$-considerable damage. In rare cases, in the case of wet ground-thin cracks on the roads.

VII. In most buildings of Group A considerable damage and in individual cases destruction. In most buildings of Group B-light damage, and in many, considerable damage. In many buildings of Group $\mathrm{C}$ light damage, with considerable damage in individual buildings.

In some cases, landslides on steep slopes of road embankments, cracks in roads, and dislocations in joints of pipelines. Stone walls damaged.

VIII. In many buildings of Group $A$ there is destruction and individual buildings collapse. In most bulldings of Group $B$ there is considerable damage, and destruction in individual ones. In most buildings of Group C light damage and in many of them considerable damage.

Small slides on steep banks of cuts or embankments of roads. In individual cases piping joints break. Statues and tombstones shlft. Stone walls are destroyed.

IX. In many buildings of Group A-collapse. In many buildings of Group B-destruction and individual ones collapse. Many buildings of Group C are considerably damaged and some are destroyed.

In individual cases, railroad tracks are twisted and embankments damaged. Many cracks in roads. Breaking and damaging of pipelines. Monuments and statues overturned. Most stacks and towers destroyed.

$\mathrm{X}$. In many bulldings of Group $\mathrm{B}$-collapse. In many buildings of Group $\mathrm{C}$-destruction and in some cases collapse.

Considerable damage to embankments and dams. Local bending of rails. Breaks in pipelines. Roads crack in many places and are deformed; smokestacks, towers, and monuments, stone walls collapse.

$X I$. Total destruction of buildings.

Destruction of embankments over great lengths. Pipelines become completely useless. Railroad tracks bent over great lengths.

$\mathrm{XII}$. Total destruction of buildings and structures.

Realdunl phenomens in ground with change in status of ground and unrface water Intensity:

I. No damage.

II. No damage.

III. No damage.

IV. No damage.

V. Small waves in unstable water reservoirs. In some cases the spring flow is changed.

VI. Cracks in wet ground with widths up to $1 \mathrm{~cm}$. In mountainous regions there are sporadic cases of slides and crumbling of ground. Small changes in the spring flow and the water level in wells.

VII. Thin cracks in dry ground. Large numbers of cracks in wet ground. Individual cases of slides on river banks. Small slides in mountainous regions and crumbling of ground. Possible landslides in the mountains.

In individual cases the water becomes muddy in reservolrs and in rivers. The spring flow and the water level are changed. In some cases new springs appear or existing ones are lost.

VIII. Cracks in ground reach several centimeters. Many cracks on slopes of mountains and in wet ground. Extensive crumbling of ground, slides, and mountain landslides. Water in the reservoirs becomes turbid. New water reservoirs are produced. New springs of water appear and existing ones are lost. In many cases the spring flow and the water level in wells change. 
IX. Fissures in ground reach widths of $10 \mathrm{~cm}$, and more than $10 \mathrm{~cm}$ on slopes and river banks. Large number of thin flssures in ground. Mountain landslides. Many slides and crumbling of ground. Small mud eruptions. Pronounced waves on water reservoirs. New water springs frequently arise or old ones disappear.

$\mathrm{X}$. Fissures in ground with widths of several decimeters and in individual cases reaching $1 \mathrm{~m}$. Rock slides in mountainous regions and at the seashore. Large mudflows of sand and clay. Surf and splashing of water in reservoirs and rivers. New lakes are produced.

XI. Numerous fissures are produced on the surface of the earth. Vertical displacement of strata. Large landslides and earth slips. Watersaturated friable sediments come out of the fissures. The conditions in the springs and water reservoirs change strongly, as well as the ground-water level.

XII. Large scale change in the relief. Tremendous landslides and earthslides. Considerable vertical and horizontal faulting and displacement. Large changes in the state of the ground and surface waters. Waterfalls are produced. Lakes are produced. River beds change. Other symptoms

Intensity:

I. Earthquakes not felt by persons. The oscillations of the earth are registered with instruments.

II. Noticed by individual persons who are very sensitive and who are perfectly at rest.

III. Oscillations noted by a few persons who are at rest inside buildings. Careful observers note only a slight swinging of hanging objects.

IV. Light swaying of hanging objects and of standing automobiles. Slight vibration of liquids in vessels. Slight ringing of densely stacked unstable dishes.

Earthquake perceived by most people located indoors. In rare cases sleepers are awakened. Felt by individual people outdoors.

V. Hanging objects swing noticeably. In rare cases pendulums of wall clocks stop. Water splashes sometimes from filled vessels. Unstable dishes and ornaments on shelves sometimes topple over.

Felt by all persons inside buildings and by majority of persons in the outdoors; all wake up. Animals are restless.

VI. Hanging objects swing. Sometimee books fall off shelves and pictures shift. Many pendulums of wall clocks stop. Light furniture shifts. Dishes fall.

Many persons run out of the houses. Movement of persons unatable. Animals run out of shelter.

VII. Chandeliers swing strongly. Light furniture shifts. Books, vessels, and vases fall down.

All persons run out of the buildings and in individual cases jump out of windows. It is difficult to move without support.

VIII. Some hanging lampa are damaged. Furniture shifts and frequently tilts over. Light objects jump and tilt over. Persons can stand on their feet with difficulty. All run out of buildings.

IX. Furniture topples over and breaks. Animals very panicky.

$X$. Numerous damages to household goods. Animals cry and howl.

XI. Loss of life, anima!s, and property under fragments from building 6 .

XII. Great catastrophe. A considerable part of the population is killed by collapse of the buildings. Vegetation and animals destroyed by avalanches and landelides in mountainous regions. 


\begin{tabular}{|c|c|c|c|c|}
\hline Rossi-Forel & $\begin{array}{l}\text { Modified } \\
\text { Mercalli }\end{array}$ & JMA & Geofian & MSK \\
\hline \multirow{2}{*}{ I } & I & 0 & I & I \\
\hline & & \multirow{3}{*}{ I } & II & \\
\hline II & II & & \multirow{2}{*}{ II I } & 11 \\
\hline II I & III & & & III \\
\hline IV & \multirow{2}{*}{ IV } & II & IV & IV \\
\hline V & & \multirow{2}{*}{ I I I } & \multirow[b]{2}{*}{ v } & \multirow{2}{*}{ v } \\
\hline \multirow{2}{*}{ VI } & V & & & \\
\hline & \multirow{2}{*}{ VI } & \multirow[t]{2}{*}{ IV } & \multirow{2}{*}{ VI } & \multirow[t]{2}{*}{ VI } \\
\hline VII & & & & \\
\hline \multirow{2}{*}{ VIII } & VII & \multirow{2}{*}{ v } & VII & VII \\
\hline & VIII & & VIII & VIII \\
\hline IX & IX & \multirow{2}{*}{ VI } & IX & IX \\
\hline \multirow{3}{*}{$x$} & $x$ & & $x$ & $x$ \\
\hline & $X I$ & \multirow{2}{*}{ VII } & $X I$ & $X I$ \\
\hline & XII & & XII & XII \\
\hline
\end{tabular}

FIGURE C.1 GRAPHIC COMPARISON OF SEISMOLOGICAL INTENSITY SCALES

$$
\text { C-15 }
$$




\section{REFERENCES}

Ambraseys, N., "The Correlation of Intensity with Ground Motions," Proceedings of the 14th Conference of the European Seismic Committee, Trieste, September 1974 .

Barosh, P. J., Use of Seismic Intensity Data to Predict the Effects of Earthquakes and Underground Nuclear Explosions in Various Geologic Settings, USGS Bulletin 1279, 1969.

Gupta, I. N., "A Note on Correlation of Modified Mercalli Intensity with Peaks of Far-Field Ground Motion," BulZetin of the Seismological Society of America, Vol. 70, pp. 925-32, 1980.

Gutenberg, B., and C. F. Richter, "Earthquake Magnitude, Intensity, Energy and Acceleration," Buzletin of the Seismological Society of America, Vol. 32, pp. 163-191, 1942 .

Gutenberg, B., and C. F. Richter, "Earthquake Magnitude, Intensity, Energy, and Acceleration," Bulletin of the Seismological Society of America, Vol. 46, pp. $105-145,1956$.

Hershberger, J., "A Comparison of Earthquake Accelerations with Intensity Ratings," Bulletin of the Seismological Society of America, Vol. 46, pp. 317-320, 1956.

Medvedev, S. V., W. Sponheuer, and V. Karnik, "Seismische Skala," Proceedings of the Third Wortd Conference on Earthquake Engineering, New Zealand, 1965.

Medvedev, S. V., and W. Sponheuer, "Scale of Seismic Intensity," Proceedings of the Fourth World Conference on Earthquake Engineering, Santiago, Chile, 1969.

Richter, C. F., EZementary Seismology, Freeman, San Francisco, 1958. 
Rossi, M. S., "Programma dell' Osservatorio ed Archivo Centrale Geodinamico," Boll. del Vulcanismo Italiano, Vol. 10, pp. 3-124 (Rossi-Forel scale, pp. 67-68), 1883 .

Scholl, R. E., "Statistical Analysis of Low-Rise Building Damage Caused by the San Fernando Earthquake," Bulletin of the Seismological Society of America, Vol. 64, No. 1, 1974.

Sieberg, A., Erabebenkunde, Jena, Ficher, August 1923.

Trifunac, M. D., and A. G. Brady, "On the Correlation of Seismic Intensity with Peaks of Recorded Strong Ground Motion, "BulZetin of the Seismological Society of America, Vol. 65, No. 1, 1975.

Wood, H. O., and F. Neumann, "Modified Mercalli Intensity Scale of 1931," Bulzetin of the Seismological Society of America, pp. 277-283, 1931. 
APPENDIX D

Engineering Intensity Scale 



\section{ENGINEERING INTENS ITY SCALE}

\section{D.1 Formulation of the Engineering Intensity Scale (EIS)}

The EIS was developed by Blume* to serve as a systematic and orderly means for facilitating a rapid and simple reporting of the engineering intensity of ground shaking at a site. Engineering intensity implies a measure of ground shaking that is useful for performing engineering analyses and is readily interpretable for designing structures.

In the formulation of the scale, ground motion is characterized by 5\%-damped response spectrum velocity $\left(S_{v}\right)$, and structures are characterized by their fundamental-mode vibration properties. Disregarding mode-shape considerations, the variables important for correlating ground motion with damage are $S_{v}$ amplitude and building period $(T)$. A damping value of $5 \%$ is used because damping in many real structures varies from about $2 \%$ to $10 \%$, and $5 \%$ has become a standard reference level in investigations analyzing the response of structures to ground motion.

The EIS procedure provides an orderly means for relating ground motion amplitudes for various frequencies with structures having specific frequency characteristics. The range of $S_{v}$ and $T$ values applicable to civil engineering structures is represented as a $10 \times 9$ matrix, shown in Figure D.1. The range of $S_{v}$ values, from 0.001 to $1000.0 \mathrm{~cm} / \mathrm{sec}$, is divided into ten levels that are assigred engineering intensity (EI) numbers from 0 to 9 . The $T$ range, from 0.01 to $10 \mathrm{sec}$, is divided into nine period bands from I to IX. Table 0.1 lists the 5\%-damped $S_{v}$ amplitude boundary values represented by the intensity levels shown in the figure.

\section{D.2 EIS Reporting}

Three ways of reporting earthquakes using the EIS have been found useful. The most accurate is a nine-digit report in which an El number is reported for each of the period bands shown in Figure D.1. If the response spectrum

*Blume, J. A., "An Engineering Intensity Scale for Earthquakes and Other Ground Motion," Bulletin of the Seismological Society of America, Vol. 60, No. 1, February 1970. 
does not cross a particular period band, the letter $X$ is substituted for the El number of that band. To facilitate reading, groups of three digits in the report are separated by a comma. For applications that require somewhat less detailed reporting, an average of each group of three consecutive El numbers is taken, which results in a three-digit report. Finally, the most abbreviated and least descriptive report consists of a single digit obtained by averaging the intensity numbers of the three-digit report.

The Nine-Digit Report. The response of the north-south component of the 1940 El Centro, California, earthquake will be used as an example of a ninedigit report. In Figure $0.1, S_{v}$ values for this earthquake, recorded at El Centro, are shown with the EIS diagram superimposed. The nine-digit intensity for this particular response spectrum would read: $x 56,777,76 x$.

The first $X$ indicates that the response spectrum does not enter period band I (from 0.01 to $0.1 \mathrm{sec}$ ), often the case because of recording-instrument $1 \mathrm{imi-}$ tations or because of inadequately fine digitization of the spectral response calculation. In period band II, $S_{v}$ generally falls between 10 and $30 \mathrm{~cm} / \mathrm{sec}$; in band III, between 30 and $60 \mathrm{~cm} / \mathrm{sec}$; and in bands IV through VIII, between 60 and $100 \mathrm{~cm} / \mathrm{sec}$. The $\mathrm{final} X$ indicates that the response spectrum fails to enter band $I X$, again possibly because of instrument limitations. The nine digits represent a rough plot of the response spectrum. They are easily transmitted and stored and provide data useful for correlating the frequency content of ground motion with the characteristic responses of structures of various periods.

Note that a number reported for period band I would represent a general indication of peak ground acceleration because damping and dynamic amplification have little effect in the short period of this band. The spectral response is asymptotic to peak ground acceleration. Likewise, a response reported for period band IX is indicative of maximum ground displacement.

An ElS report with relatively high numbers indicates very strong earthquake motion at the locality under consideration. A report with only a few high numbers may indicate a narrow-band spectrum of response to either a small, local energy release or a large, distant energy release. 
The Three-Digit Report. Although it gives less information than the ninedigit report, the three-digit report may be more convenient for many purposes.

Before averaging the values in the three groups of period bands of the ninedigit report, $X$ values must be enumerated. This is done by estimating where the response spectrum would fall if extended through the $X$ column, bearing in mind the asymptotic conditions noted above. The value is usually taken to be one unit less than that reported for the adjoining column. For example, the El Centro response spectrum reported as $\times 56,777,76 \times$ would become $456,777,765$. The three-digit report, obtained by averaging each group of three digits, would thus read: 5,7,6. The commas are retained in the notation to identify the scale and the source of the rating.

The period bands of the three-digit report, described as short $(T<0.4$ $\mathrm{sec})$, intermediate $(T=0.4$ to $2.0 \mathrm{sec})$, and long $(T>2.0 \mathrm{sec})$, represent typical classes of buildings. This report shows at a glance where the energy would fall in each period group and how buildings in each class would tend to respond.

The One-Digit Report. For limited purposes, a crude report that merely indicates the overall spectral content of ground motion may be sufficient. This is obtained by averaging the EI numbers of the three-digit report to produce a single number. In the case of the El Centro example, that number would be 6 .

If reporting purposes are best served by the use of a single digit to rate a seismic event but at the same time would benefit by a finer comparison among events, a scale of 30 ratings can be obtained by subdividing the $S_{v}$ range represented by each of the ten EI numbers (see Figure D.1) into three parts. For example, a one-digit report of 6 , which represents an $S_{v}$ range of 30 to $60 \mathrm{~cm} / \mathrm{sec}$, can be subdivided into ranges of 30 to $40 \mathrm{~cm} / \mathrm{sec}, 40$ to $50 \mathrm{~cm} / \mathrm{sec}$, and 50 to $60 \mathrm{~cm} / \mathrm{sec}$. These narrower ranges are identified in the $E 1$ report by the use of a plus sign, a minus sign, or no sign at all with the single digit. Thus a report of 6 - indicates the lowest part of the EI- 6 range (30 to $40 \mathrm{~cm} / \mathrm{sec}), 6$ indicates the middle of the range $(40$ to $50 \mathrm{~cm} / \mathrm{sec}$ ), and $6+$ the highest part $(50$ to $60 \mathrm{~cm} / \mathrm{sec}$ ). The narrower range thus reported is based on the result obtained when the numbers of the three-digit report are 
averaged: the average of a $6,7,6$ three-digit report is therefore reported as $6+$ while the average of $6,6,5$ is reported as $6-$.

Combined Report. It is possible, of course, to report all three ratings in order to allow the user to select the one most useful for his purposes. On this basis, the 1940 El Centro north-south component would be reported to have an intensity of:

$$
\begin{gathered}
\times 56,777,76 x \\
5,7,6 \\
6
\end{gathered}
$$

Experience has shown that, except for special purposes, the three-digit report offers the optimum combination of convenience and usefulness.

\section{Engineering Intensity Maps}

Isointensity (iso-El) maps can be constructed if sufficient spectral data are available. It is possible to prepare a map for each of the nine period bands, but a convenient alternative is to use the short-period, intermediateperiod, and long-period bands of the three-digit report $(T<0.4 \mathrm{sec}$; $T=$ 0.4 to $2.0 \mathrm{sec}$; and $T>2.0 \mathrm{sec}$ ).

Another alternative is to construct maps for particular narrow-period bands of interest. Figure D.2, an example of such a map, shows iso-El lines for the period band $T<0.2 \mathrm{sec}$ for an underground nuclear detonation that took place on January 18, 1968, in central Nevada. Spectral response curves were calculated for various stations, as shown in the figure. 
TABLE D. 1

ENGINEERING INTENSITY SCALE BOUNDARY $S$ VALUES

\begin{tabular}{|c|c|c|c|}
\hline \multirow{2}{*}{$\begin{array}{c}\text { EIS } \\
\text { Intensity } \\
\text { Level }\end{array}$} & \multicolumn{3}{|c|}{$S_{v}$ Value } \\
\cline { 2 - 4 } & $(\mathrm{cm} / \mathrm{sec})$ & $(\mathrm{in} . / \mathrm{sec})$ & $(\mathrm{ft} / \mathrm{sec})$ \\
\hline 9 & $>300$ & $>118$ & $>9.84$ \\
8 & $100-300$ & $39.4-118$ & $3.28-9.84$ \\
7 & $60-100$ & $23.6-39.4$ & $1.97-3.28$ \\
6 & $30-60$ & $11.8-23.6$ & $0.984-1.97$ \\
5 & $10-30$ & $3.94-11.8$ & $0.328-0.984$ \\
4 & $4-10$ & $1.57-3.94$ & $0.131-0.328$ \\
3 & $1-4$ & $0.394-1.57$ & $0.0328-0.131$ \\
2 & $0.1-1$ & $0.039-0.394$ & $0.0033-0.0328$ \\
1 & $0.01-0.1$ & $0.0039-0.039$ & $0.00033-0.0033$ \\
0 & $<0.01$ & $<0.0039$ & $<0.00033$ \\
\hline
\end{tabular}

$D-5$ 


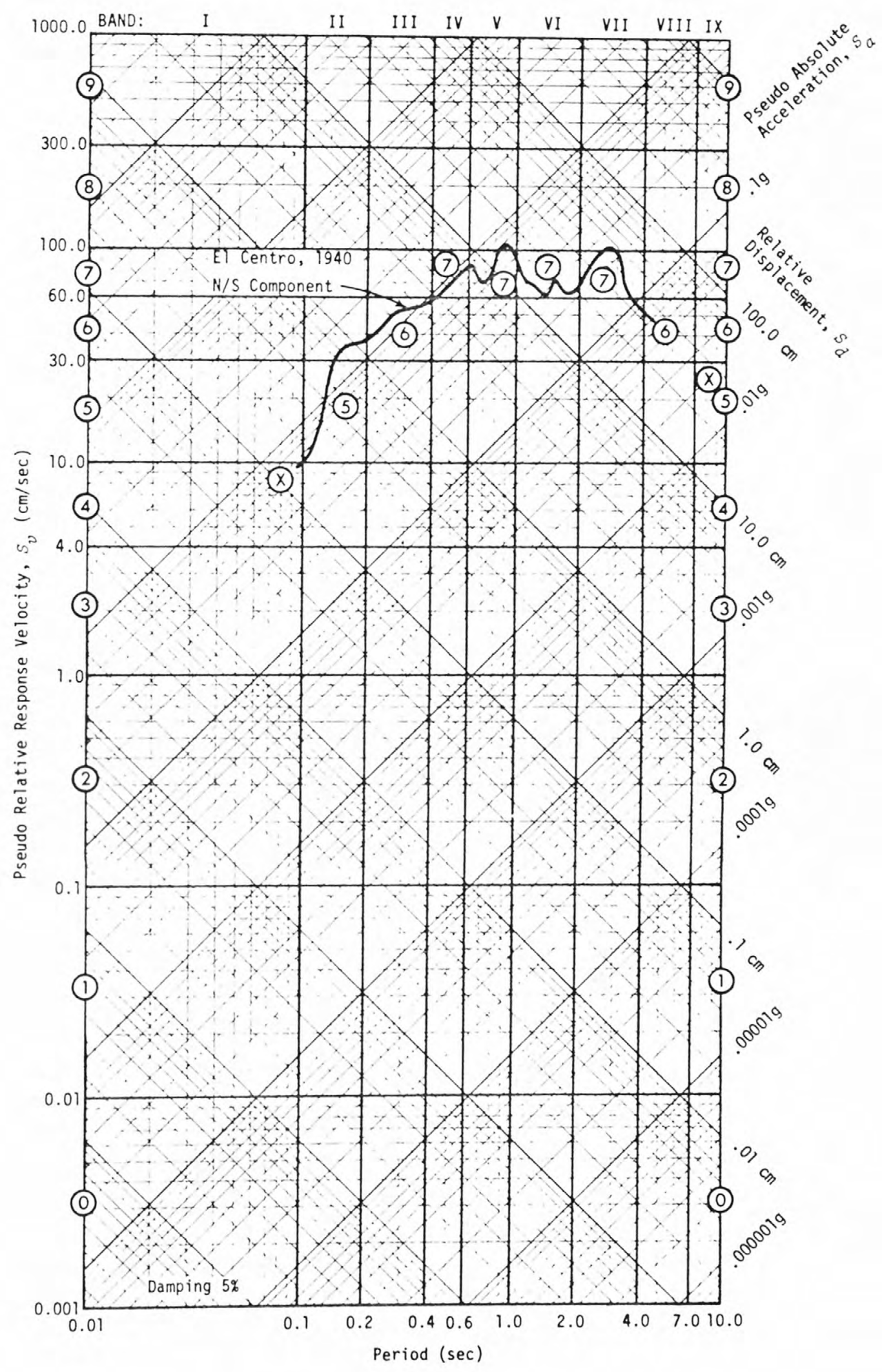

FIGURE D.1 ENGINEERING INTENSITY SCALE MATRIX SUPERIMPOSED WITH EXAMPLE SPECTRUM 


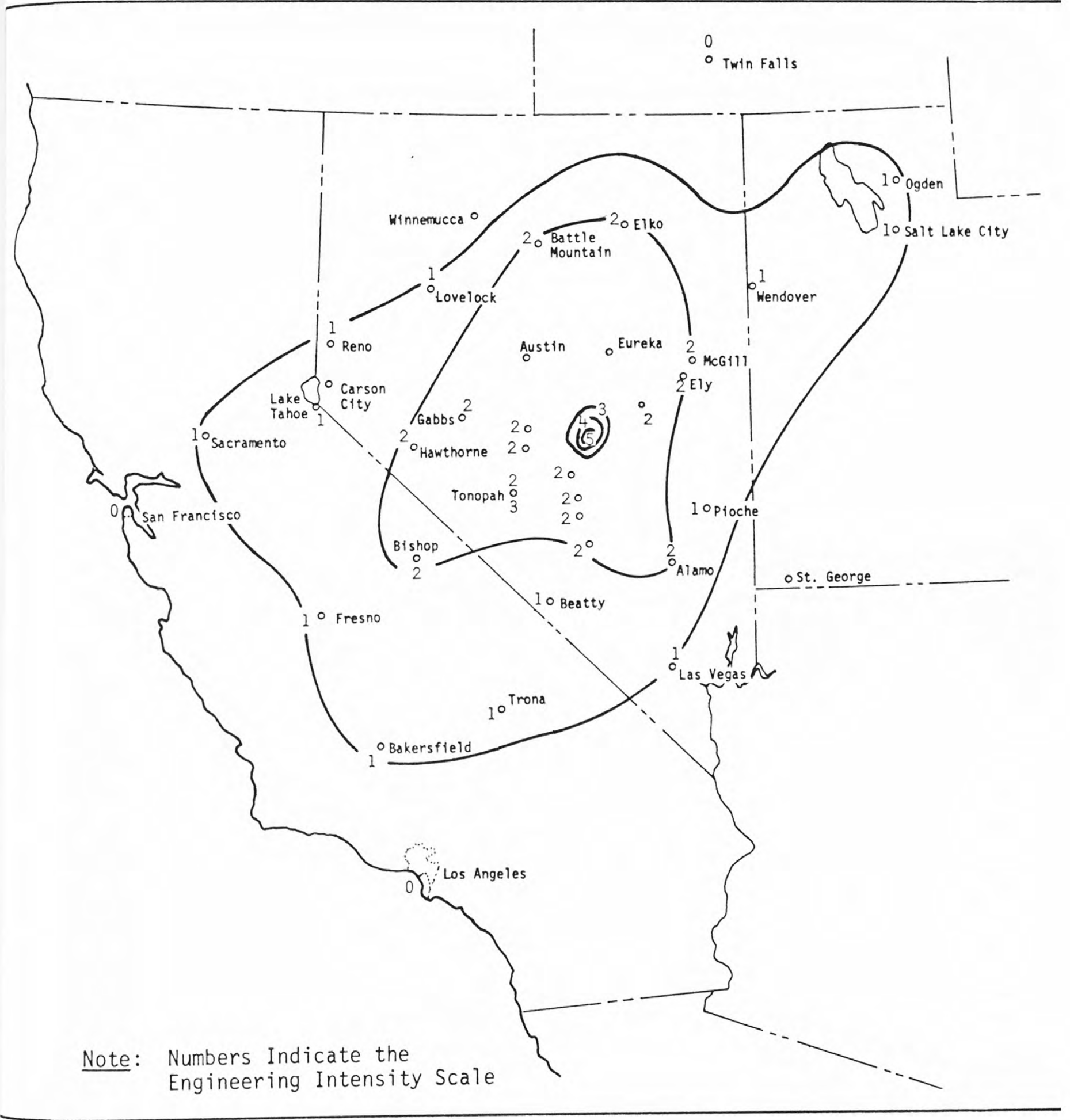

FIGURE D.2 ISO-EI LINES FOR PERIOD BAND OF $T<0.4$ SEC, EVENT FAULTLESS 


\section{APPENDIX E}

Review of Lognormal Distribution Used for Statistical Analysis of Response Spectra 

The purpose of this appendix is to show how Agbabian Associates analyzed their data and used lognormal distribution to perform statistical analysis.

The data used by Agbabian Associates consisted of digitized ground response spectra. California Institute of Technology (CIT) was the source of the data. From each of 372 horizontal records and 186 vertical records, five sets of spectra (damping ratios of $0.0,0.02,0.05,0.10$, and 0.20 ) were computed. Each spectrum was defined in terms of pseudo velocities provided at 91 discrete frequencies between $0.06 \mathrm{~Hz}$ and $25 \mathrm{~Hz}$. Table E.1 gives further descriptions of the CIT records.

Three statistical methods were considered in the report by Agbabian Associates titled Correzation of Ground Response Spectra with Modified Mercalli Intensity (June 1977). These three methods were (1) counting method, (2) Gaussian distribution, and (3) lognormal distribution. Lognormal distribution was chosen from among these methods. The following is a brief summary of lognormal distribution.

Lognormal Distribution: A random variable, $Y$, is said to have a lognormal distribution if the natural logarithm of $Y$ follows a Gaussian distribution. The resulting expression for lognormal distribution is

$$
f_{Y}(y)=\frac{1}{\sqrt{2 \pi} \sigma_{X} y} \exp \left[-\frac{1}{2}\left(\frac{\ln y-\mu_{X}}{\sigma_{X}}\right)^{2}\right] \quad y>0
$$

or:

$$
f_{Y}(y)=\frac{1}{\sqrt{2 \pi} y \ln N} \exp \left\{-\frac{1}{2}\left[\frac{1}{\ln N} \ln \left(\frac{y}{\breve{Y}}\right)\right]^{2}\right\} \quad y>0
$$

where:

$$
X=\ln y
$$


$\mu_{X}=\frac{\sum_{i=1}^{n} \ln y_{i}}{n}$

$\vec{Y}$ denotes median of $y$

$N=$ Geometric standard deviation

$=\exp \left\{\ln \left[\left(\frac{\sigma_{Y}}{\mu_{Y}}\right)^{2}+1\right]\right\}^{1 / 2}$

$\mu_{Y}=\exp \left[\mu_{X}+\frac{1}{2} \sigma_{X}^{2}\right]$

$$
\sigma_{Y}=\mu_{Y}\left[\exp \left(\sigma_{X}^{2}\right)-1\right]^{1 / 2}
$$

To understand some of the probability terms, inverse distribution is used. Let $F$ be the lognormal distribution as defined in Equation (E-1) or Equation $(E-2)$. Then the inverse distribution function is $F^{-1}(y)$, where $0<y<1$. $\vec{Y}=F^{-1}(0.5)$, is called the median of $E$, and not to be confused with mean of $F, \mu_{X}$, as defined in Equation $(E-4) . F^{-1}(k / 100)$ is called the k-percentile. For example, lognormal 16 th percentile means that by integrating the lognormal distribution from zero to a certain point of $y, 16 \%$ of the area is obtained. Likewise, lognormal 84 th percentile means that $84 \%$ of the area under the curve is obtained. Figure E-1 shows a sample curve of lognormal distribution with $\sigma_{\ln Y}=1.0$.

The significance of using 16 th and 84 th percentiles is to allow comparison with results from normal distribution. For standardized normal distribution, $N(0,1), N(1)=0.84$, and $N(-1)=0.16$. 
TABLE E.1

SUMMARY OF CIT DATA FOR STATISTICAL ANALYSIS

\begin{tabular}{|c|c|c|c|c|c|c|c|c|c|c|}
\hline \multirow{2}{*}{ Classification } & \multirow{2}{*}{$\begin{array}{c}\text { Spectral } \\
\text { Damping } \\
\text { Ratio }\end{array}$} & \multirow{2}{*}{$\begin{array}{l}\text { Direction } \\
\text { of Motion }\end{array}$} & \multirow{2}{*}{$\begin{array}{l}\text { Total } \\
\text { Sample } \\
\text { Size }\end{array}$} & \multicolumn{7}{|c|}{$\begin{array}{l}\text { Sample Size for } \\
\text { Each Site Intensity Level }\end{array}$} \\
\hline & & & & $<\mathrm{IV}$ & v & VI & VII & VIII & $x$ & Total \\
\hline $\begin{array}{l}\text { Data classed according } \\
\text { to site intensity only; no } \\
\text { additional classifications } \\
\text { according to site conditions }\end{array}$ & $\begin{array}{l}0.0,0.02 \\
0.05,0.10 \\
0.20\end{array}$ & $\begin{array}{l}\text { Horizontal } \\
\text { Vertical }\end{array}$ & $\begin{array}{l}372 \\
186\end{array}$ & $\begin{array}{l}8 \\
4\end{array}$ & $\begin{array}{l}68 \\
34\end{array}$ & $\begin{array}{r}132 \\
66\end{array}$ & $\begin{array}{l}150 \\
75\end{array}$ & $\begin{array}{r}12 \\
6\end{array}$ & 2 & $\begin{array}{l}372 \\
186\end{array}$ \\
\hline
\end{tabular}




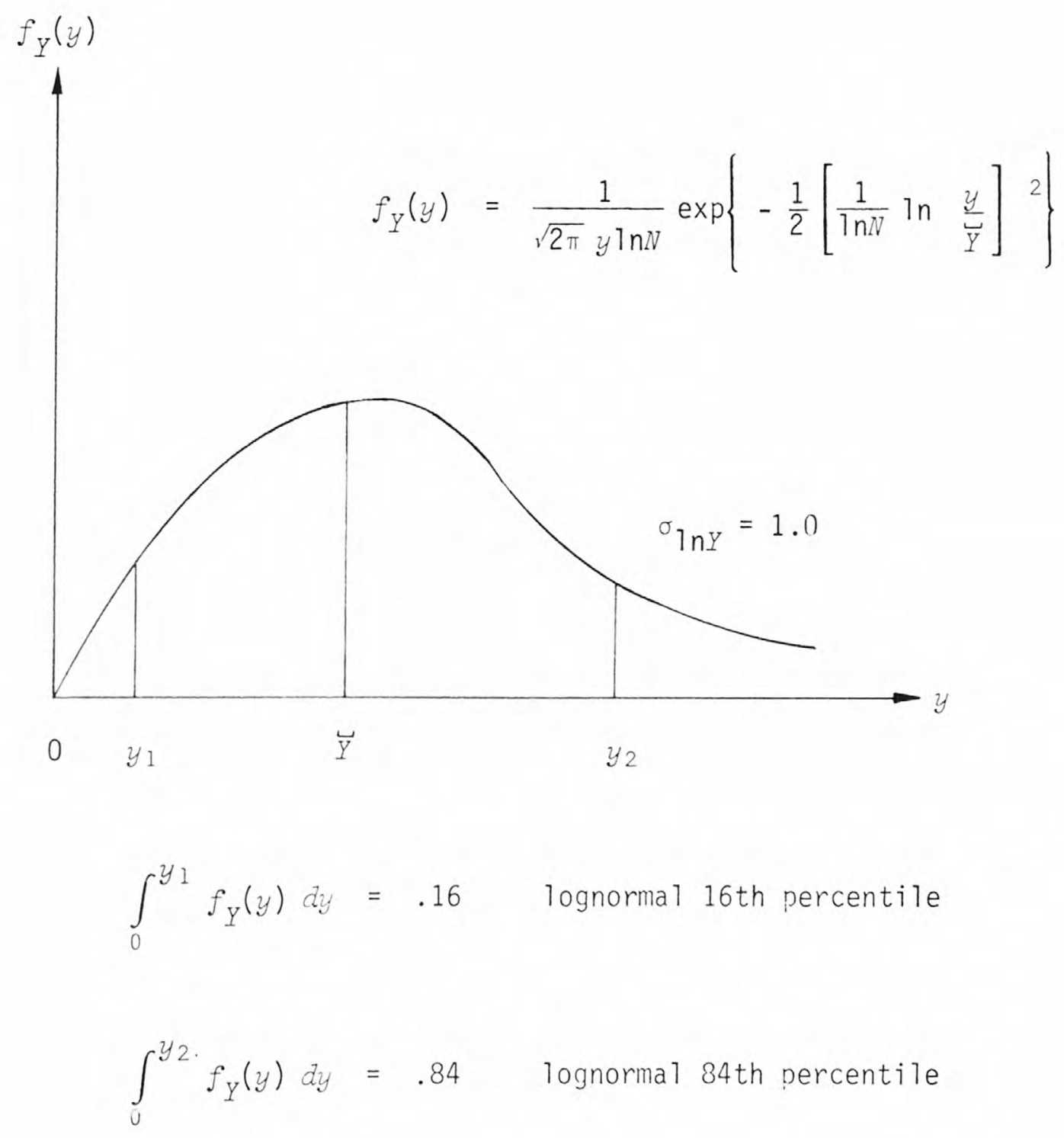

FIGURE E.1 LOGNORMAL DISTRIBUTION OF $\sigma_{7 n Y}=1.0$

$$
\text { E-4 }
$$


APPENDIX F

Damage Functions 



\section{DAMAGE FUNCTIONS}

To denote the structural damage, we will adopt a normalized scale ranging from zero to unity, with zero indicating "no damage" and unity indicating "total damage." Some suggested damage functions follow.

In the Spectral Matrix Method (Reference F1), the damage function is defined as a function of ductility $\mu$ :

$$
D F=\left(\frac{\mu-1}{\mu_{u l t}-1}\right)^{k}=\frac{\text { repair cost }}{\text { replacement cost }}
$$

where $k$ is an economic scale factor, and $\mu_{u l t}$ is the ultimate ductility.

Ductility is obtained by equating the energy absorbed by the structure when the response is taken to be elastic to the energy absorbed by an inelastic structural model. This relationship is shown in Figure F.1, where the variables are defined. For the elastic-demand model, the energy is given by:

$$
E=\frac{1}{2} \frac{V_{e}^{2}}{K}
$$

For the inelastic-capacity model, the energy is given by:

$$
E=\frac{1}{2} \frac{V^{2}}{K}+\frac{V+V_{y}}{2}\left(\Delta-\Delta_{y}\right)
$$

But:

$$
V=K \Delta_{y}+\left(\Delta-\Delta_{y}\right) \xi K \text {, and } \mu=\Delta / \Delta_{y}
$$

Therefore:

$$
E=\frac{1}{2} \frac{V^{2}}{K}\left[2(\mu-1)+(\mu-1)^{2} \xi+1\right]
$$


By equating Equations (F.1) and (F.3), an expression for ductility, $\mu$, can then be obtained:

$$
\mu=1-\frac{1}{\xi}+\sqrt{\frac{1}{\xi}\left[\frac{1}{\xi}+{\frac{V_{e}}{V_{y}}}^{2}-1\right]}
$$

where $\xi$ is a bilinear parameter, as shown in Figure F.2, and $\frac{V_{e}}{V_{y}}$ is the ratio of ground motion demand over damage-resisting capacity, $D / C$.

Substituting Equation (F.6) into Equation (F.1), we have:

$$
\begin{aligned}
D F= & 0 \\
& \text { if } D / C \leq 1 \\
D F= & {\left[\frac{\sqrt{1+\xi\left[\frac{D}{C}{ }^{2}-1\right]}-1}{\xi\left(\mu_{u l t}-1\right)}\right]^{k} } \\
& \text { if } 1<D / C \leq \sqrt{2 \mu u l t-1+\xi\left(\mu_{u l t}-1\right)^{2}} \\
D F= & 1 \text { if } D / C>\sqrt{2 \mu_{u l t}-1+\xi\left(\mu_{u l t}-1\right)^{2}}
\end{aligned}
$$

The ground motion demand, $D$, imposed on a structure and the damage-resisting capacity, $C$, of the structure are considered to be random variables with appropriate associated probability functions. The probability of the quotient $D / C$ exceeding a certain value $x$ is given by the probability density function:

$$
p_{D / C}(x)=\int_{-\infty}^{\infty}|c| p_{D, C}(x c, c) d c
$$


where $p_{D, C}(x c, c)$ is the joint probability density for demand and capacity, and $x$ is the specified value of $D / C$.

The standard procedure for computing the moments of a function of a random variable produces the following general expressions for the first and second moments of the damage factor:

$$
\begin{aligned}
E(D F)= & \int_{1}^{1 \mathrm{im}} p_{D / C}(x)\left[\frac{\sqrt{1+\xi\left(x^{2}-1\right)}-1}{\xi(\mu u l t-1)}\right]^{k} d x \\
& +\int_{1 \mathrm{im}}^{\infty} p_{D / C}(x) d x \\
E\left(D F^{2}\right)= & \int_{1}^{1 \mathrm{im}} p_{D / C}(x)\left[\frac{\sqrt{1+\xi\left(x^{2}-1\right)}-1}{\xi\left(\mu_{u l t}-1\right)}\right]^{2 k} d x \\
& +\int_{1 \mathrm{im}}^{\infty} p_{D / C}(x) d x
\end{aligned}
$$

where:

$$
\lim =\sqrt{2 \mu_{u l t}-1-\xi\left(\mu_{u l t}-1\right)^{2}}
$$

If $D$ and $C$ are taken as following lognormal and Weibull distributions, respectively, then the lognormal probability of demand is given by:

$$
p_{D}(d)=\frac{1}{\sqrt{2 \pi} a \operatorname{Ln}(N)} e^{-\frac{1}{2}\left[\frac{1}{\operatorname{Ln}(N)} \operatorname{Ln} \frac{d}{v}\right]^{2}}, d>0
$$

where:

$$
\begin{aligned}
\breve{D} & =\text { median demand value } \\
N & =\text { geometric standard deviation } \\
d & =\text { known value of demand } \\
D & =\text { demand (as a random variable) } \\
\text { Ln } & =\text { log with base e }
\end{aligned}
$$


Figure F.3 shows examples of the lognormal probability density function of demand.

The Weibull probability of $C$ is:

$$
p_{C}(c)=\frac{k}{u}\left(\frac{c-\varepsilon}{u}\right)^{k-1} e^{-\left(\frac{c-\varepsilon}{u}\right)^{k}}, c>\varepsilon
$$

where:

$$
\begin{aligned}
\bar{C} & =\varepsilon+u \Gamma\left(1+\frac{1}{k}\right) \\
V_{C} & =\frac{u}{\bar{C}} \sqrt{\Gamma\left(1+\frac{2}{k}\right)-\Gamma^{2}\left(1+\frac{1}{k}\right)} \\
\Gamma(\cdot) & =\text { the gamma function of } . \\
c & =\text { known value of capacity } \\
C & =\text { capacity (as a random variable) } \\
\varepsilon & =\text { shift in capacity axis }
\end{aligned}
$$

Figure F. 4 shows examples of Weibull probability density functions of capacity.

If it is reasonable to assume that demand and capacity are independent, then $P_{D, C}(d, c)$ can be factored as follows:

$$
p_{D, C}(d, c)=p_{D}(d) p_{C}(c)
$$

Combining Equations (F.8) and (F.13), and using the definitions for $p_{D}(d)$ and $p_{C}(c)$ given by Equations $(F .11)$ and $(F .12), p_{D / C}(x)$ is expressed as follows:

$$
p_{D / C}(x)=\frac{k \int_{\varepsilon}^{\infty}\left(\frac{c-\varepsilon}{u}\right)^{k-1} e^{-\left\{\left(\frac{c-\varepsilon}{u}\right)^{k}+\frac{1}{2}\left[\frac{1}{\operatorname{Ln}(N)} \operatorname{Ln} \frac{x c}{u}\right]^{2}\right\} d c}}{\sqrt{2 \pi} x u \operatorname{Ln}(N)}
$$


A similar damage function was defined by 01 iveira (Reference F2) as follows:

$$
\begin{aligned}
& D F=0, \text { if } Z<Y_{d} \\
& D F=\left(\frac{Z-Y_{d}}{X-Y_{d}}\right)^{\alpha} \text {, if } Y_{d} \leq Z \leq X \\
& D E=1, \text { if } Z>X
\end{aligned}
$$

where $Z=$ maximum $d i s p l a c e m e n t$ response; $Y_{d}=$ yield displacement; $X$ = displacement at collapse point; and $\alpha=$ a material and structural parameter. To account for the uncertainty of the building resistance, $Z, Y_{d}$, and $X$ are considered to be random variables. The probability density function of $D F$ is then:

$$
\begin{aligned}
p_{D E}(u)= & \int_{\xi} \int_{\gamma} p_{Z, Y_{d}, X}\left(\xi, \frac{\xi-u^{1 / \alpha} \gamma}{1-u^{1 / \alpha}, \gamma}\right) \mid \frac{1}{\alpha} u^{1 / \alpha-1} \\
& {\left[\frac{\xi-\gamma}{\left(1-u^{1 / \alpha}\right)^{2}}\right] \mid d \xi d \gamma }
\end{aligned}
$$

Another damage function, applicable to structures subjected to low-cycle, high-amplitude reversed plastic deformation, was suggested by Yao and Munse (Reference F3):

$$
D F=\sum_{i=1}^{n}\left[\left(\frac{\Delta q}{\Delta q_{1}}\right)^{1 / m}\right]_{i}
$$

where $1 / m=$ a parameter depending upon the ratio of cyclic-compressive change in plastic strain to the subsequent tensile change in plastic strain; $\Delta q=$ percentage of cyclic-tensile change in plastic true strain; $\Delta q_{1}=$ percentage cyclic-tensile change in plastic true strain at $n=1$; and $n=$ number of applications of tensile load prior to fracture. In terms of the notation of Equations (F.1 and (F.15), which may be treated as special cases of Equation (F.17), the following correspondences can be made: 


$$
\begin{aligned}
& \Delta q=\mu-1 ; \Delta q_{1}=\mu_{\mathrm{ult}}-1 ; \frac{1}{m}=k \\
& \Delta q=Z-Y_{d} ; \Delta q_{1}=C-y_{d} ; \frac{1}{m}=\alpha
\end{aligned}
$$

The validation of these damage functions, as well as the estimation of their parameters, requires further trials to correlate with data obtained from surveys of damage due to seismic motion and from the response of mathematical models to given disturbances. 


\section{REFERENCES}

F1. Blume, J. A., R. E. Scholl, and P. K. Lum, Domage Factors for Predicting Earthquake Dollar Loss Probabilities, prepared under Contract 14-08-0001-15888 for the U.S. Geological Survey, URS/John A. Blume \& Associates, Engineers, San Francisco, December 1977.

F2. Oliveira, C. S., Seismic Risk Analysis for a Site and a Metropolitan Area, Report No. EERC-75-3, Earthquake Engineering Research Center, University of California, Berkeley, August 1975.

F3. Yao, J. T. P., and W. H. Munse, "Low-Cycle Axial Fatigue Behavior of Mild Steel," ASTM Special Technical Publication No. 338, 1962. 


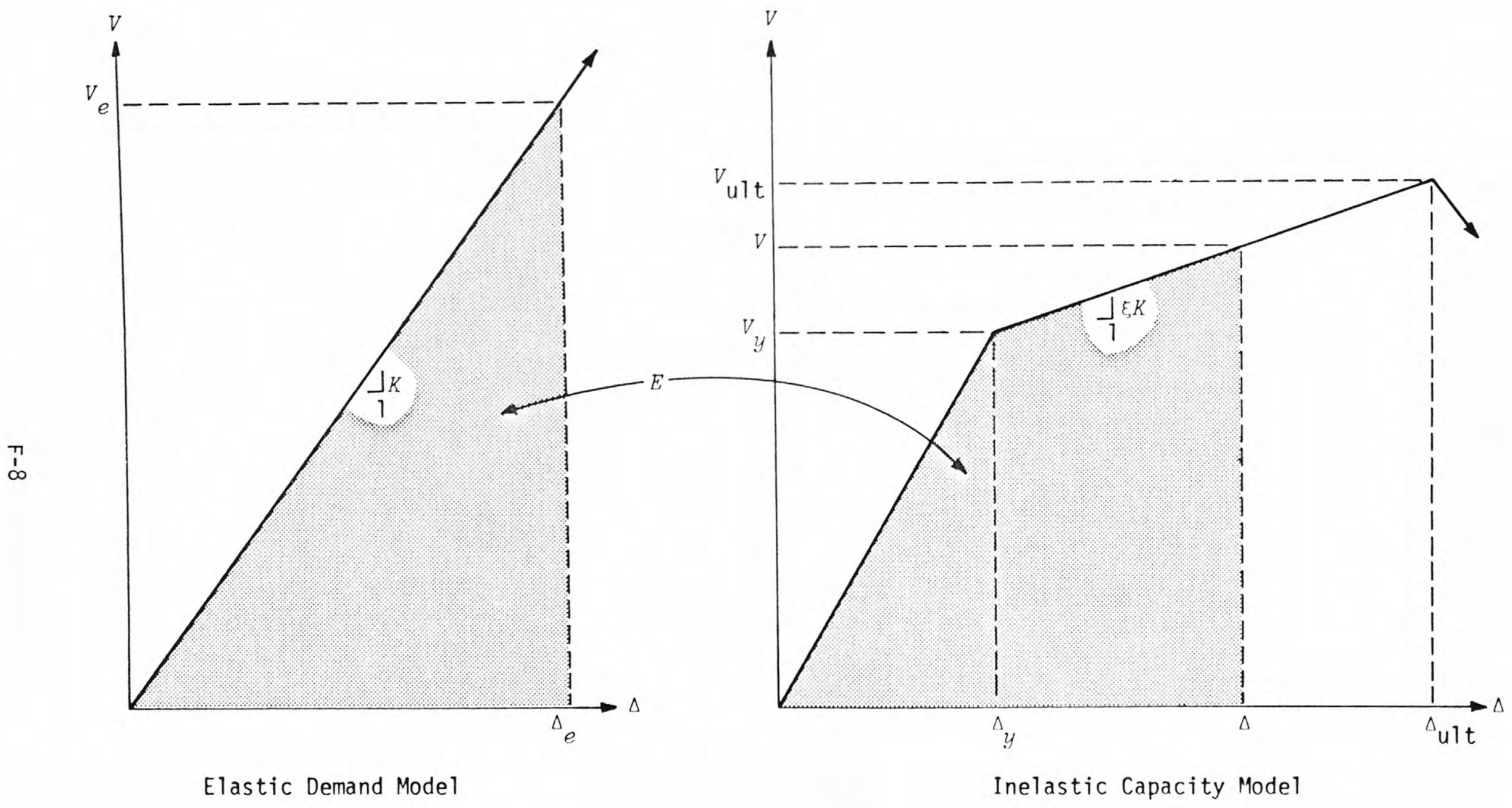

FIGURE F.1 DEMAND AND CAPACITY ENERGY MODELS 


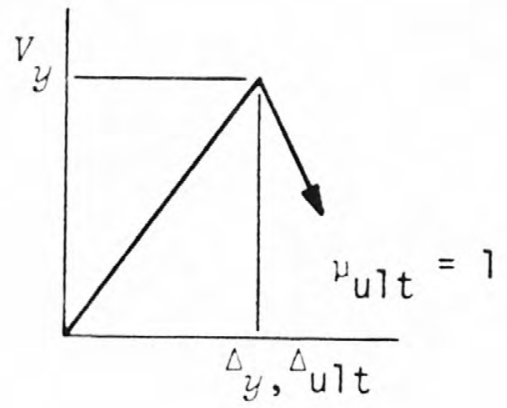

Type I

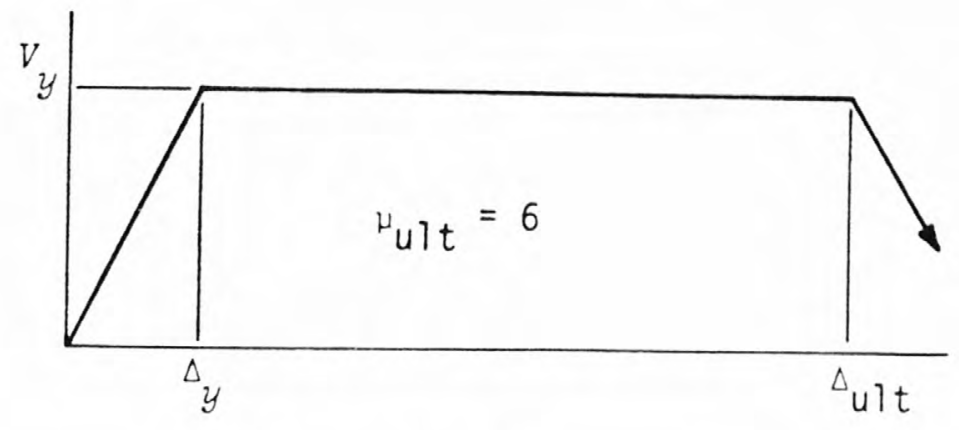

Type II

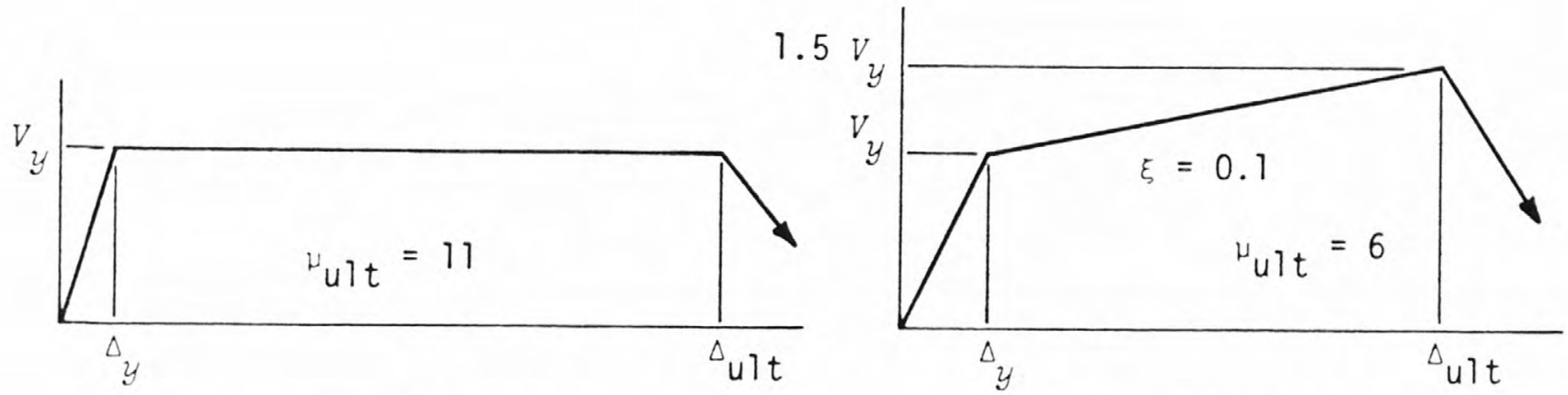

Type III

Type IV

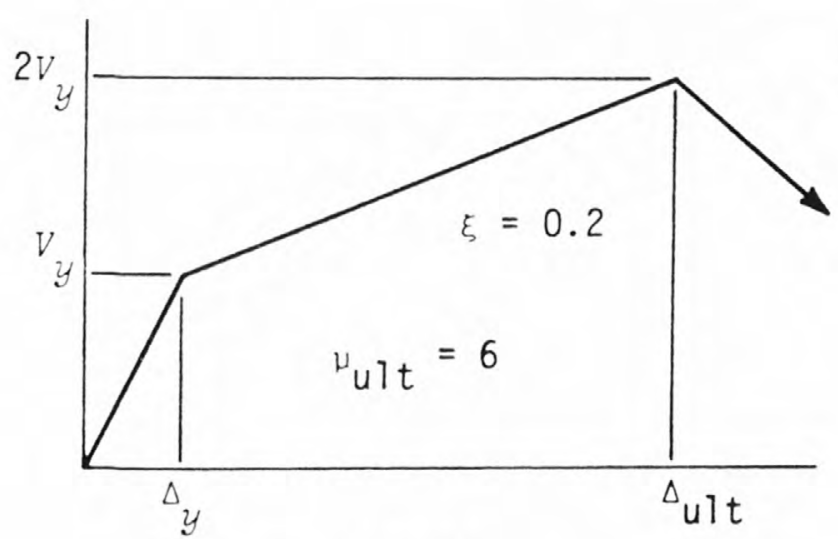

Type V

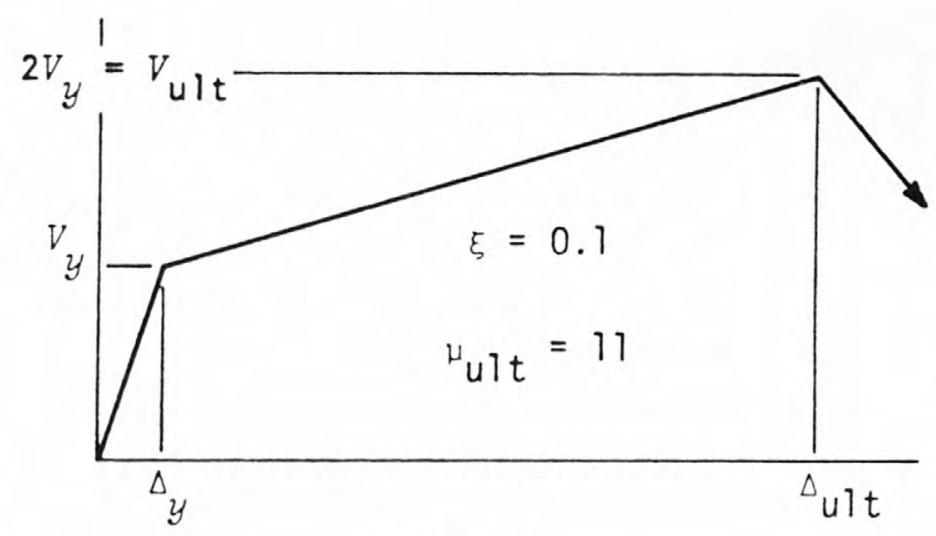

Type VI

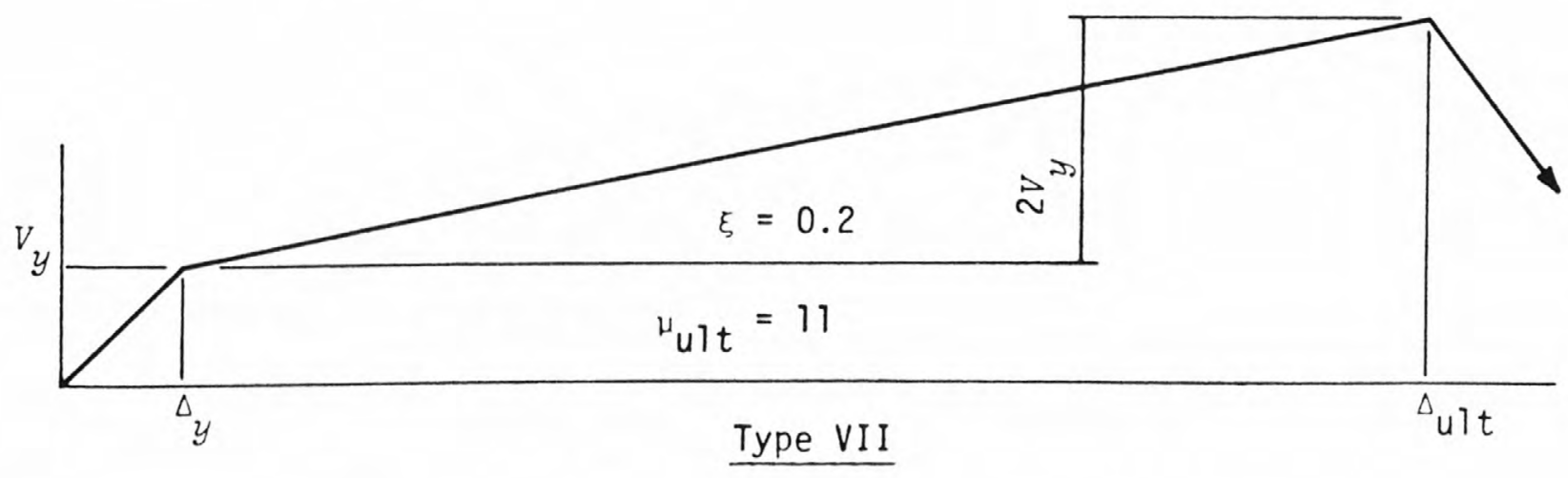

Note: Scale and values vary from model to model.

FIGURE F.2 INELASTIC MODELS OF ASSUMED ONE-MASSED SYSTEMS 


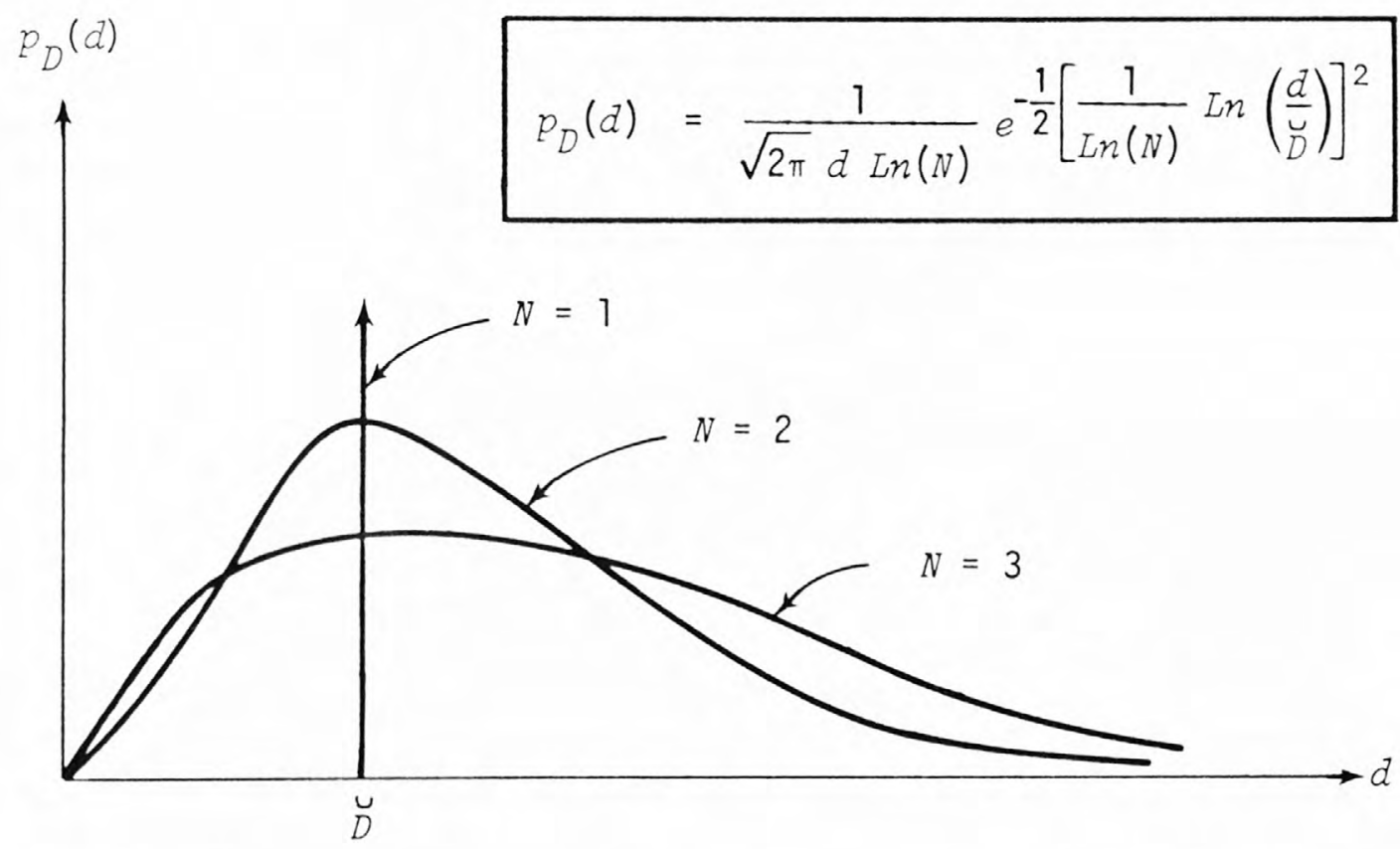

FIGURE F.3 EXAMPLES OF LOGNORMAL PROBABILITY DENSITY FUNCTIONS OF DEMAND

$$
F-10
$$




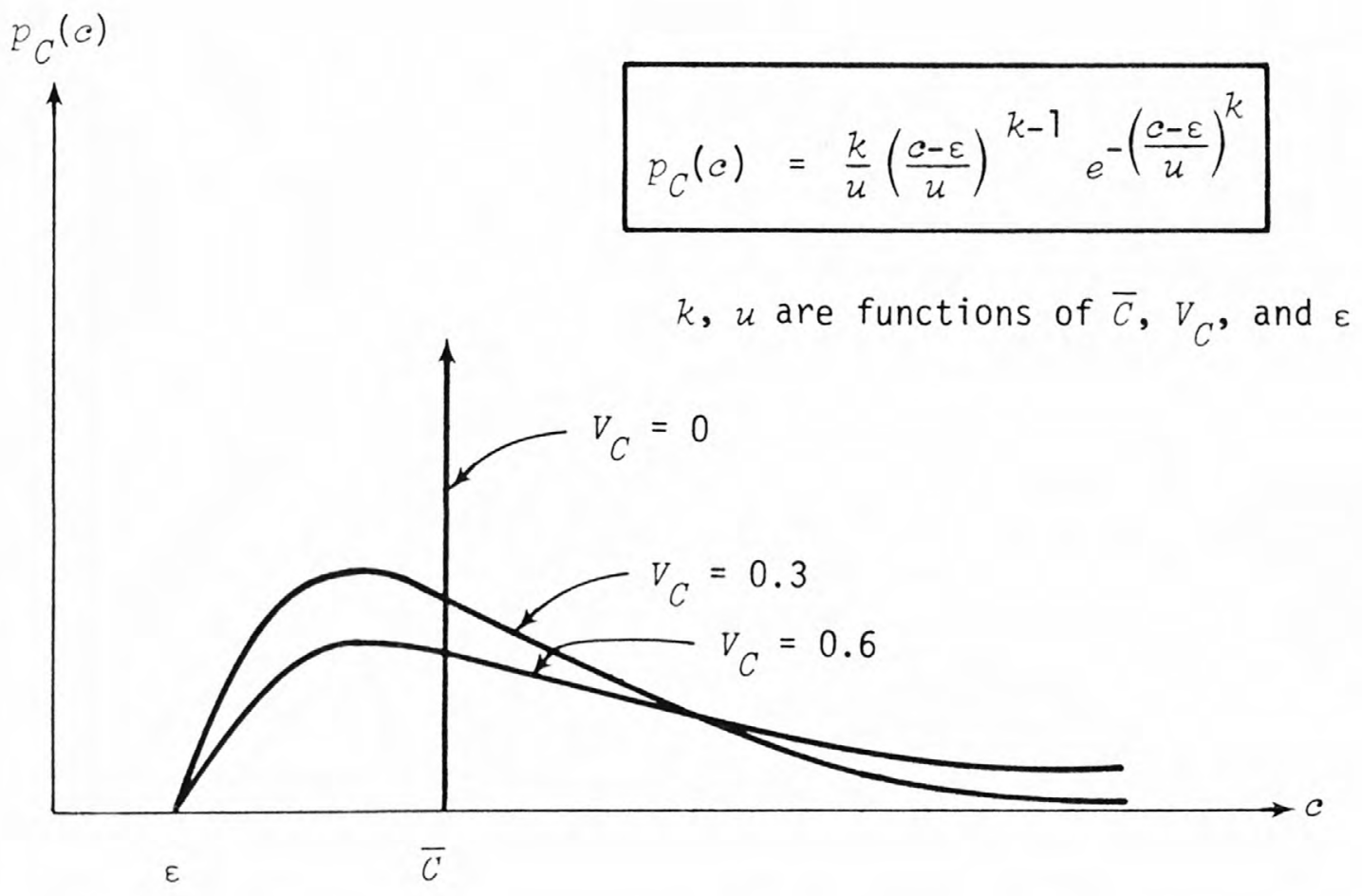

FIGURE F.4 EXAMPLES OF WEIBULL PROBABILITY DENSITY FUNCTIONS OF CAPACITY 
